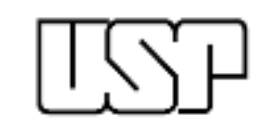

UNIVERSIDADE DE SÃO PAULO

ESCOLA DE COMUNICAÇÕES E ARTES

\title{
Interferências sonoras
}

Um estudo sobre processos de criação na Livre Improvisação

a partir de referências (des)(re)territorializadas do cancioneiro paraguaio

Miguel Eduardo Díaz Antar

São Paulo 2021 


\title{
एᄄis \\ UNIVERSIDADE DE SÃO PAULO \\ ESCOLA DE COMUNICAÇÕES E ARTES
}

\section{Interferências sonoras}

Um estudo sobre processos de criação na Livre Improvisação

a partir de referências (des)(re)territorializadas do cancioneiro paraguaio

\author{
Miguel Eduardo Díaz Antar
}

Tese apresentada à Escola de Comunicações e Artes da Universidade de São Paulo como exigência parcial para obtenção do título de Doutor em Música, sob a orientação do Prof. Dr. Rogério Luiz Moraes Costa.

[versão corrigida - versão original disponível na biblioteca da ECA/USP] 
AUTORIZO A REPRODUÇÃO E DIVULGAÇÃO TOTAL OU PARCIAL DESTE TRABALHO, POR QUALQUER MEIO CONVENCIONAL OU ELETRÔNICO, PARA FINS DE ESTUDO E PESQUISA, DESDE QUE CITADA A FONTE.

Catalogação na Publicação

Serviço de Biblioteca e Documentação

Escola de Comunicações e Artes da Universidade de São Paulo

Dados fornecidos pelo autor

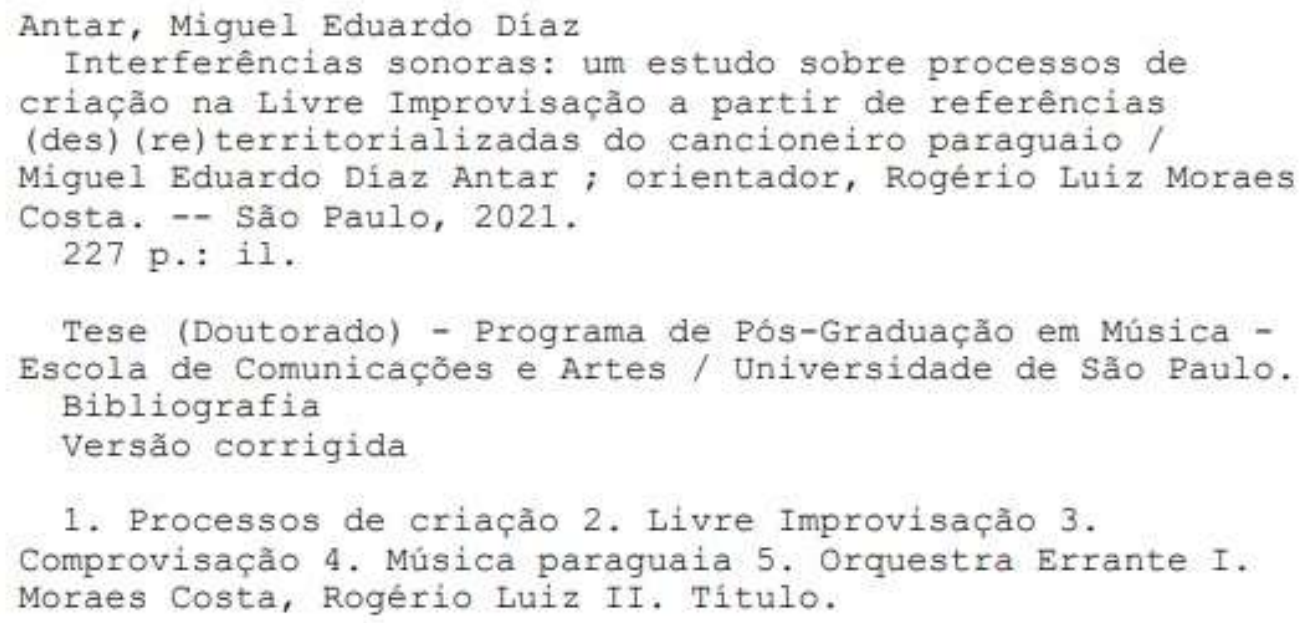

Elaborado por Alessandra Vieira Canholi Maldonado - CRB-8/6194 


\section{Interferências sonoras}

Um estudo sobre processos de criação na Livre Improvisação

a partir de referências (des)(re)territorializadas do cancioneiro paraguaio

Tese apresentada à Escola de Comunicações e Artes da Universidade de São Paulo (ECAUSP) para obtenção do título de Doutor em Música - Área de concentração: Processos de Criação Musical.

Aprovado em: 14 de abril de 2021

\section{BANCA EXAMINADORA}

Prof. Dr.: Rogério Luiz Moraes Costa

Instituição: ECA - USP

Profa. Dr.: Fernando lazzetta

Instituição: ECA - USP

Profa. Dra.: Ana Luisa Fridman

Instituição: UFRGS

Profa. Dra.: Sonia Goussinsky

Instituição: Escola Superior de Artes Celia Helena

Profa. Dr.: César Villavicencio

Instituição: UNESP 


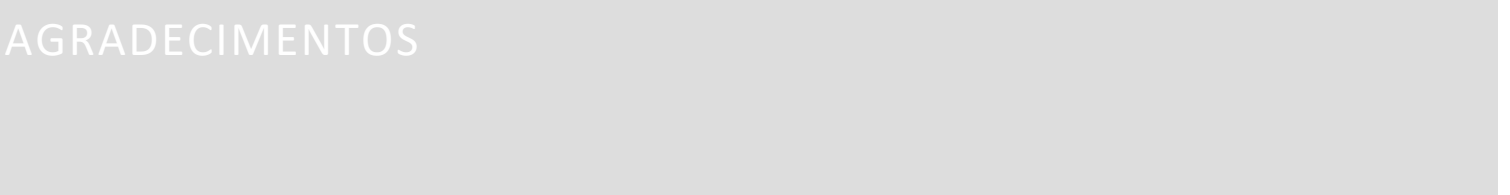

A Dios.

À Yonara, pelo amor, companheirismo e imensa ajuda para realizar este trabalho.

A mis padres, Miguel y Betty, por el ejemplo de vida que guía mis pasos.

A mi abuelo, Pedro Antar, por tanta alegría e inspiración.

Ao professor Rogério Costa, pela amizade e orientação em todos esses anos.

Às professoras Ana Fridman e Sonia Goussinsky, e aos professores Fernando lazzetta e César Villavicenvio, por aceitarem o convite e pelas contribuições ao trabalho.

Às queridas Orquestra Errante e KairosPania Cia. Cênico Sonora pelas parcerias ao longo dessa trajetória.

Aos amigxs do NuSom e da Sonora, por ampliar meus horizontes de pesquisa.

Aos professores e professoras, amigos e amigas, de Paraguay e Brasil, pelas vivências que enriquecem minha vida.

À FAPESP (processo 2017/09285-9), pelo apoio a esta pesquisa.

Com muito carinho e honra, agradeço a todos e todas.

Aguyje! Obrigado! 
Para "ieio" y Arami 
Esta pesquisa aborda possibilidades de criação artística a partir da mútua interferência entre referências da música paraguaia e procedimentos de livre improvisação musical, duas questões que são fundamentais na minha trajetória como artista pesquisador. Sob essa perspectiva, desenvolvo um estudo que aciona as ideias de jogo, performance e criação coletiva/colaborativa a partir da exploração de referências paraguaias nos grupos Orquestra Errante e KairosPania Cia. Cênico Sonora, vinculados ao Núcleo de Pesquisas em Sonologia (NuSom) da USP. As interferências entre referências paraguaias e procedimentos experimentais de criação que foram explorados em ambos os grupos criaram uma zona de atrito, reflexão e movimento de onde retirei questões sobre linguagem e territórios artísticos, composição e improvisação grupais, a utilização de referências e diretrizes nos processos criativos, retroalimentando em certa maneira novos processos criativos com os grupos e que resultaram na criação de performances apresentadas dentro e fora da universidade.

Palavras-chave: Processos de criação, Livre Improvisação, Comprovisação, Música paraguaia, Orquestra Errante. 
Esta investigación aborda posibilidades de creación artística a partir de la mutua interferencia entre referencias de la música paraguaya y procedimientos de la libre improvisación musical, dos cuestiones que son fundamentales en mi trayectoria como artista investigador. Desde esa perspectiva, desarrollo un estudio que acciona las ideas de juego, performance y creación colectiva/colaborativa a partir de la exploración de referencias paraguayas en los grupos Orquestra Errante y KairosPania Cia. Cênico Sonora, vinculados al Núcleo de Pesquisas em Sonologia (NuSom) de la USP. Las interferencias entre referencias paraguayas y procedimientos de creación experimental que se desarrollaron en ambos grupos creó una zona de fricción, reflexión y movimiento de la que extraje reflexiones sobre el lenguaje y los territorios artísticos, la composición e improvisación grupal, el uso de referencias y directrices en los procesos creativos, que en cierto modo retroalimentan nuevos procesos creativos con los grupos y que resultaron en la creación de performances presentadas dentro y fuera de la universidad.

Palabras clave: Procesos de creación, Libre Improvisación, Comprovisación, Música paraguaya, Orquesta Errante. 
Ko jetypeka oheka mba'éichapa umi mba'e apopyre ojojuhu pe mba'epurory ha umi tempiapo pyahu, mokoï mba'e iñimportante tereíva chéve guarã. Ko ñema'ere, ajapo peteî jetypeka iopurúva ñembosarai ha mba'e apopyre oî hápe umi aty hérava Orkesta Errante ha KairosPania Cía. Cénico Sonora, oñembo'aty imi Núcleo de Pesquisas em Sonología USP rehegua. Umi jejuhu paraguai apo ha jejapo pyahu, omoheñói pe tenda hérava zona de fricción, reflexión ha movimiento, upégui aguenohê py’a ñemongueta umi ñe'ê rembiapo ha tembiapo pyahu arte rehagua, ha ioko chugui kuéra umi tembiapo pyahu universidad jere ha universidad ryepy pegua.

Ñe'â atâ: Tembiapo pyahu, Jejaporei, Comprovisación, Purahéi paraguai, Orkesta Errante. 
This research deals with possibilities of artistic creation coined from mutual interference between references of Paraguayan music and procedures found in free musical improvisation, two fundamental practices in my trajectory as an artist-researcher. With this perspective, I develop a study that activates the ideas of play, performance and collective/collaborative creation drawing from Paraguayan references in the groups Orquestra Errante and KairosPania Cia. Cênico Sonora, both associated with Núcleo de Pesquisas em Sonologia (NuSom) at USP. The interferences between the Paraguayan references and experimental creative procedures used in both groups, created a zone of attrition, reflection and movement from where I draw questions regarding languages and artistic territory, group composition and improvisation, the use of references and directions in creative processes, all feeding back into new creative processes with these groups resulting in the creation of performances presented both in and outside the university.

Keywords: Creation processes, Free Improvisation, Comprovisation, Paraguayan music, Orquestra Errante. 
$\begin{array}{lr}\text { Minha tRajetóRIA NA USP } & 15\end{array}$

$\begin{array}{lr}\text { INTERFERÊNCIAS ENTRE CIÊNCIA E ARTE } & 20\end{array}$

A PRESENTE PESQUISA $\quad 25$

$\begin{array}{lr}\text { METODOLOGIA DE TRABALHO } & 28\end{array}$

1. LIVRE IMPROVISAÇÃO E PROCESSOS CRIATIVOS

1.1. LIVRE IMPROVISAÇÃO: A REFORMULAÇÃO DA CRIAÇÃO COLETIVA 34

1.2. EXPRESSÃO SONORA: ENTRE AS EXPERIÊNCIAS ACUMULADAS E O ATRAVESSAMENTO DE OUTRAS REFERÊNCIAS $\quad \mathbf{4 0}$

1.3. A LIVRE IMPROVISAÇÃo É CONTRA A LINGUAGEM?

2. EXPLORANDO REFERÊNCIAS PARAGUAIAS

2.1. REFERÊNCIAS E REFERENTES: DAS TÓPICAS PARAGUAIAS ÀS IMAGENS DE COMPOSIÇÃo 51

2.2 COMPROVISAÇÃO: UM MODO DE CRIAÇÃO ERRANTE 56

2.2.1 REPRESENTAÇÕES GEOMÉTRICAS E FLUXOGRAMAS 60

2.2.2 DA TRANSCRIÇÃO À COMPROVISAÇÃO: POLCAS “ACHUITA" E “CIELITO CHOPI” 67

2.2.3. Explorando partituras-cartazes: polcas "Galopera", "Pájaro Campana" e "Cielto CHOPI". 70

2.2.4. RESSONÂNCIAS - EXPERIMENTOS SEM PARTITURAS 83

2.2.5 AMPLIANDO O OLHAR SOBRE AS REFERÊNCIAS PARAGUAIAS 84

2.2.5.1. Alejandro Cubilla: de músico militar a militante socialista 87 
3. INTERFERÊNCIAS PARAGUAIAS NA CRIAÇÃO DE PERFORMANCES INTERDISCIPLINARES 89

3.1 ComprovisaÇão: UM MOdo de CRIAÇão INDISCIPLINAR. KAIROSPANIA CIA. CÊNICO SONORA E ORQUESTRA ERRANTE

3.2. Performance "Des a grad a vel"

3.2.1 SOBRE A REFERÊNCIA MUSICAL: GUARÂNIA "LEJANIA".

3.3. Performance "A Síria não é aqui" 104

3.4. Performance "Delfina" 108

4. MÚSICAS GRAVADAS PELA ORQUESTRA ERRANTE 118

4.1. NDAJEKEHAI DE MI SUERTE AMBopúgUI ORQUeStRA ERRÁNTEPE

4.2 Lucia Purahei (Orquestra ERrante e Amigos do Paraguay)

Apêndice C. Grade da música lucia Purahei para a Orquestra ErRante e amigos do Paraguay 160

ANexo A. ARTigo: Apontamentos SObRe NARRATIVA ORAL, IDENTIDADE, MACHISMOS E FEMINISMOS NO COMPUESTO MATEO GAMARRA

ANEXo B. ARTIGo: DesintegraçÃo de VOZES, REINTEGRAÇÃo de POSSES: APONTAMENTOS SOBRE A POLCA PURAHEI JAHE'O COMO NARRATIVA DE ASPECTOS SÓCIO-HISTÓRICOS DA CULTURA PARAGUAIA 


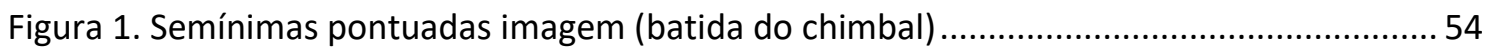

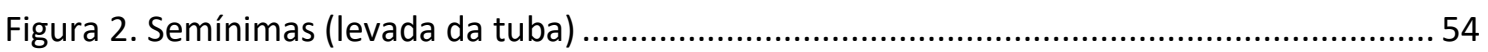

Figura 3. Semínimas e colcheias (variação rítmica típica do bumbo) ......................................... 54

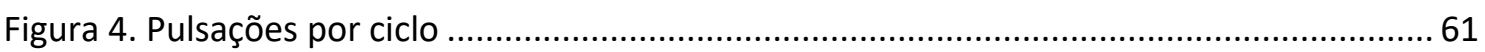

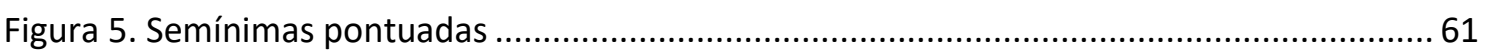

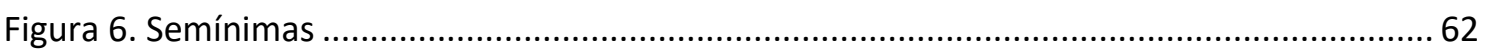

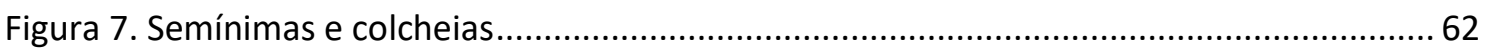

Figura 8. Padrão rítmico típico do bumbo na polca paraguaia e as notas do, sol, la, re. ........... 64

Figura 9. Padrão rítmico silêncio de colcheia + duas colcheias e as notas sol, do, fa, la............. 65

Figura 10. Padrão rítmico duas semínimas pontuadas contra três semínimas e as notas sol, re, mi, la. . .65

Figura 11. Material "meio-dia", a partir da polca "Pájaro Campana" .......................................... 73

Figura 12. Material "três horas", a partir da polca "Galopera" ..................................................... 74

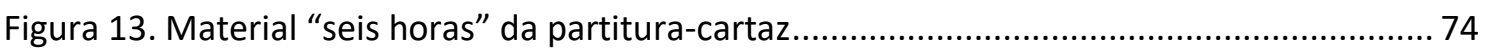

Figura 14. Material "nove horas", a partir da polca "Galopera" ................................................. 75

Figura 15. Partitura-cartaz com quatro materiais sugeridos ..................................................... 76

Figura 16. Encontros da Orquestra Errante em novembro de 2018. Registros de Yonara Dantas.

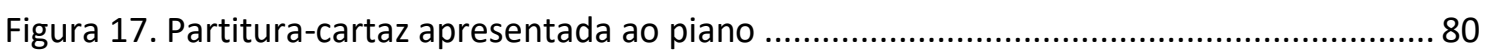

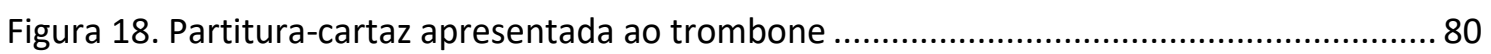

Figura 19. Mapa cênico desenvolvido para a performance "Des a grad a vel" ........................... 96

Figura 20. Partitura com as diretrizes para Rogério Costa (saxofone alto) ................................ 100

Figura 21. Partitura com as diretrizes para Fábio Martinelle (trombone baixo) ....................... 101

Figura 22. Performance "Des a grad a vel" KairosPania Cia. Cênico Sonora \& Orquestra Errante.

Figura 23. Performance "A Síria não é aqui". KairosPania Cia. Cênico Sonora \& Orquestra

Errante. Registro de autoria indefinida. Outubro 2017. 105 
Figura 24. Performance "A Síria não é aqui". KairosPania Cia. Cênico Sonora \& Orquestra

Errante. Registro de autoria indefinida. Outubro 2017.

Figura 25. Primeiros encontros de preparação para performance "Delfina". Migue Antar,

Samya Enes e Fabio Manzione. Registro Yonara Dantas. Maio 2018.

Figura 26. Carmen Estevez, na performance "Delfina". KairosPania Cia. Cênico Sonora. Registro Itamar Dantas. Agosto 2018.

Figura 27. Performance "Delfina". KairosPania Cia. Cênico Sonora. Casa Muñecas, Buenos

Aires, Argentina. Registro Yonara Dantas. Setembro 2018 
MINHA TRAJETÓRIA NA USP

Esta pesquisa trata sobre possibilidades de criação artística a partir da mútua interferência entre referências da música paraguaia e procedimentos de livre improvisação musical, duas questões que são fundamentais na minha trajetória como artista pesquisador. Nesse sentido, esta pesquisa é resultado dos estudos depreendidos na minha relação particular com o Departamento de Música da Universidade de São Paulo e as conexões de diversas abordagens musicais que essa relação me permitiu.

Sou paraguaio, nascido em Asunción em 1983. Meu pai é paraguaio, da cidade de Itá, situada a 35 km da capital, Asunción. Minha mãe é paraguaia, de ascendência árabe. Estudo e faço música desde criança. Moro na cidade de São Paulo desde 2007, ano que ingressei no curso de Graduação em Música da USP por meio do Programa EstudanteConvênio (PEC) da Embaixada do Brasil no Paraguai. Não havia faculdade pública de música no Paraguai naquele período e eu queria aprofundar minha formação, não só como instrumentista, mas como pesquisador em música. No Departamento de Música tive acesso a diversas experiências musicais: fui bolsista em atividades ligadas ao grupo coral Comunicantus, me uni a colegas para criar grupos de música autoral - grupos de música instrumental bem como de música popular e canção como os grupos Ôctôctô e a Filarmônica de Pasárgada - e me vinculei de uma maneira muito decisiva aos campos de criação musical desenvolvidos nas pesquisas dos professores Rogério Costa e Fernando lazzetta. Esses professores e seus grupos de pesquisas - Orquestra Errante e NuSom - me abriram uma perspectiva de estudo e criação em música de tal sorte que 
determinaram meu caminho como artista pesquisador e delinearam os rumos de minha trajetória na pós-graduação.

O NuSom - Núcleo de Pesquisas em Sonologia é um importante grupo de pesquisadores/as que me ajudaram muito durante minha formação e na pesquisa sobre música paraguaia. Apesar de esse não ser o objeto de pesquisa específico do grupo, foram as referências e ferramentas de pensamento que conheci nas reuniões e atividades ali desenvolvidas que me permitiram experimentar meios de relacionar pesquisa e criação, o que me possibilitou desenvolver essa perspectiva de estudo que objetiva relacionar processos contemporâneos de produção musical com minhas referências paraguaias. O NuSom, coordenado pelo Prof. Dr. Fernando lazzetta, se dedica a investigação acadêmica num ambiente interdisciplinar que integra disciplinas voltadas para os estudos do som, para a reflexão crítica sobre produção musical e para a pesquisa no campo das técnicas e tecnologias musicais. Como é característica dos grupos de estudos, o NuSom não forma parte da "grade oficial" de disciplinas e tampouco oferece créditos como tal, mas se constitui como um importante espaço para intercâmbio de reflexões, metodologias, referências bibliográficas e produções artísticas entre alunos/as e professores/as, inclusive de outras áreas de investigação, o que permite uma ampliação do horizonte formativo de seus/suas participantes.

O NuSom também é uma referência muito importante no estudo e proposição de temas como Pesquisa em artes, Estudos do som e Processos de criação. Quando cheguei ao Brasil em 2007 eu nunca tinha ouvido falar nesses termos. Foi por meio de um longo processo de aprendizado que fui me aproximando dessas temáticas e percebendo nelas uma grande janela de oportunidades, questionamentos e impulsos (por estudar, por criar, por romper) que resultam no borramento das fronteiras da música e das artes com outras áreas de pesquisas. O caráter interdisciplinar do grupo certamente exerceu muita influência para que eu pudesse pensar a investigação acadêmica musical no sentido da ampliação e conexão de possibilidades e potencias criativas com reflexões de cunho político, social e até filosófico.

Durante as reuniões semanais do NuSom, intercalam-se leituras de textos, debates que vão desde arte sonora a epistemologias decoloniais e feministas, entrevistas com 
pesquisadores/as da música e de outras áreas que procuram tecer conexões com os objetivos de pesquisa do grupo, jornadas internas para apresentação das pesquisas de cada aluno/a, proposição de mostras artísticas, entre outras iniciativas. Nesse sentido, parte das reflexões se dirige a impulsionar pesquisas e consequente publicação de textos acadêmicos, sejam artigos individuais ou colaborativos, trabalhos de conclusão de curso, dissertações e teses. E outra parte desemboca em produções artísticas, pois muitos dos/as pesquisadores/as que formam parte do NuSom integram subgrupos envolvidos com aspectos criativos das práticas sonoras.

Um desses sub-grupos que integram o NuSom é a Orquestra Errante, coordenada pelo Prof. Dr. Rogério Costa. A orquestra iniciou suas atividades com encontros semanais (que se mantem até hoje) em 2008 e a partir do ano seguinte passou a chamar-se Orquestra Errante. O trabalho da Orquestra Errante enfatiza a ideia de experimentação e criação musical em tempo real (no momento presente). Composta por alunos/as com diversas formações e experiências musicais, funciona como uma espécie de laboratório prático sobre processos de improvisação. O/a pesquisador/a que deseja trabalhar algum aspecto vinculado a improvisação musical encontra na Orquestra Errante um espaço para experimentações. Essa é uma das premissas para as pessoas que frequentam as reuniões semanais - estar disponível para participar de sessões de Livre Improvisação, permeadas ou não por propostas de jogo pré-concebidas. Assim, a cada semana o grupo se dedica a um determinado tipo de investigação criativa, se comprovam a funcionalidade (ou não) de propostas, surgem questionamentos, testam-se novas ideias, comentam-se os caminhos escolhidos etc. A intenção é que as experimentações práticas sejam acompanhadas de reflexões sobre aspectos acionados na criação, seja individual ou coletiva. E que essas reflexões alimentem o processo criativo, capazes de gerar novas propostas práticas que coloquem à prova a si mesmas. Ao ser um espaço aberto para o diálogo sobre as respectivas pesquisas de cada envolvido/a - o que permite compartilhar problemas e possíveis soluções -, a orquestra me incentivou a ampliar minhas ideias sobre música e a colaborar em diversas propostas artísticas. Na Orquestra Errante aprendi sobre construção coletiva, entrega e imaginação. Sobre esticar ideias e dispensar soluções. Sobre coragem e interação. Ela foi fundamental para 
meu crescimento como instrumentista e determinou o recorte que propus para as minhas produções acadêmicas dentro da universidade.

No meu trabalho de conclusão de curso (2012) estudei algumas perspectivas históricas e conceituais sobre a Livre Improvisação, apontando relações de aproximação e distanciamento entre essa prática e o freejazz. Já durante minha pesquisa de mestrado (2016) tive por foco o estudo da interação musical no ambiente da Livre Improvisação a partir de conexões entre essa prática e o comportamento performático do clown. A relação do corpo na performance; o estado de atenção e prontidão acentuadas; a improvisação e o risco; a potência do "erro" e a liberdade para flertar com o ridículo são alguns dos pontos que acionei a partir do estudo das permeabilidades entre o clowning e a Livre Improvisação. Em ambas as pesquisas, a Orquestra Errante foi fundamental como laboratório de teste e formulação de ideias. Ademais, muitas das questões ali levantadas continuam reverberando em minha trajetória com outros projetos de pesquisa, como é o caso do presente trabalho entre música paraguaia e Livre Improvisação.

Sendo paraguaio, pode parecer óbvio meu contato com a música do Paraguai. No entanto, essa é uma construção e, nesse sentido, preciso destacar a influência de minha família na forte relação afetiva que cultivei com a música paraguaia. Nas minhas lembranças misturam-se o dia a dia, os almoços de domingo, as festas de aniversário, as rodas de tereré, a faxina da casa etc., tudo sempre acompanhado de música paraguaia, seja no rádio ou nas coleções de discos do meu pai e do meu avô. Nesse sentido, meu avô Pedro Antar (1935-2020) foi uma grande referência. Tive o privilégio de aprender muito com ele e cultivarmos juntos o afeto pela música paraguaia. Desde que me mudei para São Paulo, cada ida para Asunción foi marcada por preciosos momentos de encontros e conversas, rodas de tereré e muita música paraguaia.

Ademais do NuSom e a Orquestra Errante, também devo mencionar outro grupo de estudos que alimenta algumas das reflexões levantadas no presente trabalho: Sonora: música e feminismos, formado com apoio do NuSom, e coordenado pelas pesquisadoras Profa. Dra. Lilian Campesato e Profa. Dra. Valéria Bonafé. O grupo Sonora funciona como uma rede colaborativa que reúne artistas e investigadores/as com 
interesse em manifestações feministas no contexto artístico. As reuniões do grupo de estudos são semanais e contam com transmissão online atingindo grande capilaridade. Nelas, são realizadas atividades como leituras de textos, debates, criação artísticas, ocupação de espaços e realização de encontros acadêmicos. No contato com esse grupo, pude perceber a importância da luta por representatividade das minorias, os privilégios envolvidos no ser homem em uma sociedade machista, a força de estudos decoloniais e como a forma de escrever e de criar podem se opor a apagamentos históricos.

Um outro grupo bastante importante como laboratório de investigação da presente pesquisa é a KairosPania Cia. Cênico Sonora. Essa companhia artística foi criada em 2016 pela minha esposa, Yonara Dantas, e por mim, com o objetivo de desenvolver produções artísticas que aliassem os procedimentos da Livre Improvisação a estratégias de criação e jogo cênico, reunindo outras disciplinas criativas. O resultado é uma companhia dedicada ao diálogo interdisciplinar, aliando dança, artes cênicas, artes plásticas e música em criações de performances onde as fronteiras entre essas disciplinas se diluem. Contando com a participação de amigas e amigos dessas mais diversas áreas, interessados em processos de hibridação, muitos de seus/suas integrantes também participam dos grupos de estudo NuSom e Orquestra Errante.

Faço destaque no peso que esses quatro coletivos (NuSom, Orquestra Errante, Sonora e KairosPania) têm na minha formação pois eles direcionaram meus estudos e promoveram ferramentas teóricas e práticas que me permitiram aproximar e desenvolver questões referentes à livre improvisação musical e à música paraguaia temas que estou tendo a oportunidade de aprofundar na presente pesquisa. Assim, da interferência entre minhas referências da música e cultura paraguaia e os procedimentos de pesquisa e criação musical que acessei no Departamento de Música da USP, emergem e se conectam pontos diversos e distantes como a Livre Improvisação, a criação colaborativa, as propostas contemporâneas de grafia musical, as perspectivas sobre as ideias de tradição e folclore, os debates sobre as imagens da mulher na música paraguaia, as condições sociais impostas pelas ditaduras na América do Sul, a necessidade de entender nossa história a partir de epistemologias decoloniais, entre 
outros assuntos. Esses temas foram pesquisados por meio de reflexões teóricas, leituras bibliográficas e desaguaram na criação de performances artísticas.

Em resumo, esses grupos de estudos me ajudaram a perceber a pesquisa artística como possibilidade de ampliação das perspectivas de estudo e criação musical, incentivandome a olhar para minha cultura, minha música, minhas referências e estudá-las nesse viés.

\section{INTERFERÊNCIAS ENTRE CIÊNCIA E ARTE}

Uma das referências acionadas pelos grupos de estudos que se mostrou fundamental em minha trajetória foi a tese do pesquisador Prof. Dr. Silvio Zamboni ${ }^{1}$, publicada em versão livro no ano de 1998 com o título A pesquisa em Arte: um paralelo entre Arte $e$ Ciência, da editora Autores Associados.

A tese propõe pensar sobre as metodologias necessárias para orientar trabalhos de artistas investigadores/as no contexto da academia. Nos primeiros tópicos abordados se observa a diluição de visões superficiais que dividem, por um lado, a investigação científica como algo "racional e fechado" e, por outro lado, a arte como algo "emocional e sensível". A partir de referências e exemplos, o Prof. Zamboni mostra como a intuição e a subjetividade também tomam parte da investigação científica, ao mesmo tempo em que todas as manifestações artísticas abrigam um caráter lógico e constituem uma forma de ordenamento consciente e racional.

A linha de pensamento que separa em opostos investigação e criação artística pode, muitas vezes, alimentar essa falsa separação, o que resulta em artistas com medo da

\footnotetext{
${ }^{1}$ O Prof. Zamboni trabalhou durante vários anos (desde 1978 até 1993) no CNPq - Conselho Nacional de Desenvolvimento Científico e Tecnológico, agência brasileira vinculada ao Ministério da Ciências, Tecnologia e Inovações. O Prof. Zamboni, foi uma das pessoas responsáveis por oficializar a área de Artes nessa instituição, possibilitando que as pesquisas artísticas recebam fomento de parte de uma agência oficial do governo.
} 
academia (por ser "fechada" e inibir a arte) e em programas de estudo universitário que desconsideram as particularidades da criação artística (por carecer da disciplina científica). Assim, ao invés de reiterar o discurso de separação, a tese do Prof. Zamboni aproxima esses polos, demostrando que na realidade pesquisa artística e pesquisa científica - mesmo que diferentes - têm características e pontos em comum.

Como em qualquer atividade humana, pesquisa enquanto processo não é somente fruto do racional; o que é racional é a consciência do desejo, a vontade e a predisposição para tal, não o processo da pesquisa em si, que intercala o racional e o intuitivo na busca comum de solucionar algo. Esses conceitos servem tanto para a ciência quanto para a arte, pois pesquisa é a vontade e a consciência de se encontrar soluções para qualquer área do conhecimento humano (ZAMBONI, 1998, p.43).

Ao aproximar pesquisa artística e científica, vemos junto com o Prof. Zamboni que a criatividade, a intuição, a racionalidade, a subjetividade, a planificação, a disciplina de estudo etc., são características comuns em ambas as formas de investigação. Além disso, os paradigmas - os problemas, as perguntas, as ferramentas disponíveis para pensar e fazer -, estão em constante movimento, gerando mudanças na forma de pensar a investigação artística e científica segundo cada momento histórico e suas necessidades.

A criação artística espelha a visão pessoal do artista, da mesma forma que a criação científica reflete a visão pessoal do cientista. A diferença entre uma obra e outra não se dará no ato criativo, mas no processo de trabalho fundamentado num determinado paradigma, e no conhecimento acumulado de quem realiza a obra (ZAMBONI, 1998, p.30).

Um ponto que parece permanecer independente do momento histórico é a necessidade sistemática de trabalho. Que, para ser bem aproveitado, carrega em si a ideia de premeditação. Nas palavras do Prof. Zamboni: "toda investigação necessita de um método para chegar a seus objetivos" (ZAMBONI, 1998, p.43). O que não quer dizer que seja um único método. Como aponta o Prof. Zamboni, cada momento histórico tem seus próprios paradigmas e, para dar conta deles, os métodos de investigação (científico e artístico) são constantemente transformados para que possam ser úteis ao seu propósito:

Método é o caminho pelo qual esses [objetivos] são alcançados. Poderá haver vários caminhos diferentes, mas existirá sempre um mais adequado para ser trilhado. Essa adequação não diz respeito somente a uma escolha no seu sentido lógico mais apurado, o adequado releva 
também o ponto de vista pessoal de quem escolhe (o que é adequado para um indivíduo obrigatoriamente pode não ser para outro), e o paradigma em que o indivíduo está atuando, pois a escolha do caminho adequado está intimamente ligado ao conjunto de regras e das teorias em que se está atuando (ZAMBONI, 1998, p.44).

Os métodos estão profundamente relacionados a seu tempo e implicados com a trajetória do/a pesquisador/a que conduz a pesquisa. Isso será determinante para as possibilidades de investigação acionadas. As produções dos grupos de estudos NuSom, Orquestra Errante e Sonora, citadas anteriormente, são exemplos de trabalhos que apontam perspectivas individuais e ao mesmo tempo colaborativas e coletivas. Um processo de encontros e interferências que demanda pontos de acordo entre os desejos individuais e os interesses coletivos, como indicam os pesquisadores Fernando lazzetta e Lilian Campesato:

As histórias, habilidades e demandas individuais, ao mesmo tempo em que colaboram para o enriquecimento dos processos criativos, funcionam também como limites para a superação da atuação individual dentro do contexto que se forma de modo participativo. Os resultados artísticos são geralmente contaminados pela constante tensão entre autonomia e subordinação, entre altruísmo e egoísmo, participação e observação (IAZZETTA, CAMPESATO, 2020, online).

Os processos de criação, o uso de tecnologias, a experimentação sonora (que inclui livre trânsito entre territórios musicais), os questionamentos sobre identidade, os estudos sobre epistemologias feministas e decoloniais, os debates sobre arte, política e sociedade etc., são todas questões que refletem interesses pessoais e que promovem diálogo no espaço de intercâmbio e trabalho que esses grupos de estudos oferecem. Essas condições também permitem, ou mesmo demandam, o compartilhamento das abordagens e metodologias aplicadas em cada pesquisa. Nesse sentido, existe uma preocupação de que as metodologias se adequem a cada objeto de estudo, e não o contrário. O Prof. Fernando lazzetta explica:

Portanto, tanto em arte quanto na ciência, a pesquisa é baseada em um conjunto de valores, ideologias e concepções de mundo. Mas enquanto na ciência o uso do método busca suprimir ou atenuar a visão individual e pessoal do objeto analisado, possibilitando a comparação entre processos, conceitos e objetos e a vinculação com leis gerais, na arte o método pode ser só uma ferramenta para conduzir a experiencia individual, especulativa. Refere-se mais a uma "desordem" experimental do que a um processo de estabelecimento de modos comuns de realizar a investigação. Cada obra pode ser conduzida por 
um método particular e a ideia de generalidade, tão apreciada pela ciência, pode ter pouca importância diante de um processo de pesquisa artística (IAZZETTA, 2017, p.24 - tradução minha²).

Essa "desordem" experimental diz respeito à liberdade na manipulação dos materiais musicais e sonoros, à experiência sensorial, à ação dos corpos e à vivência dos processos criativos que se depreendem da sua vinculação aos processos de experimentação.

Criar é trazer ao mundo algo que ainda não existe a partir daquilo que já existe. Criar é transformar aquilo que já é, em algo que só existe em potência. Esse processo não acontece ao acaso, mas precisa ser construído, e esse jogo entre o conhecido e o desconhecido, entre aquilo que já existe e o devir, é articulado pelo processo de experimentação. Tanto na ciência quanto na arte, a experimentação é um dos motores que permite não necessariamente o avanço do conhecimento no sentido positivista, mas a sua constante rearticulação diante das contingências com as quais elas - arte e ciência - dialogam. 0 experimento traz um gosto de contemporaneidade àquilo que produzimos, não porque represente um acréscimo ao estoque de conhecimento que temos, mas porque o experimento implica sempre experimentar um acontecimento (IAZZETTA, 2017, p.32-33 - tradução minha $\left.{ }^{3}\right)$.

A experimentação é uma característica essencial da arte. Nesse sentido os pesquisadores defendem a abrangência do termo experimental. Embora em alguns casos um determinado repertório possa ser chamado de "experimental" dada a presença marcada de desvios dos lugares (territórios musicais) comuns, a partir do uso

\footnotetext{
${ }^{2}$ No original: Por lo tanto, tanto en arte como en ciencia la investigación se apoya en un conjunto de valores, ideologías y concepciones del mundo. Pero mientras en la ciencia el empleo del método busca suprimir o atenuar la visión individual y personal del objeto analizado, posibilitando la comparación entre procesos, conceptos y objetos y la vinculación a leyes generales, en arte el método puede ser solamente una herramienta para conducir la experiencia individual, especulativa. Se refiere más a un "desorden" experimental que a un proceso de establecimiento de modos comunes de hacer investigación. Cada obra puede ser conducida por un método particular y la idea de generalidad, tan apreciada por la ciencia, puede tener poca importancia delante a un proceso de investigación artística (IAZZETTA, 2017, p.24).

${ }^{3}$ No original: Crear es traer para el mundo algo que todavía no existe a partir de aquello que ya existe. Crear es transformar aquello que ya es en algo que sólo existe en potencia. Este proceso no se da por casualidad, sino que necesita ser construido, y este juego entre lo conocido y lo desconocido, entre aquello que ya existe y el devenir, es articulado por el proceso de experimentación. Tanto en la ciencia como en el arte, la experimentación es uno de los motores que permite, no necesariamente el avance del conocimiento en el sentido positivista, sino su constante rearticulación delante de las contingencias con las cuales ellos - arte y ciencia - dialogan. El experimento trae un gusto de contemporaneidad a aquello que producimos, no porque represente un añadido en el caldo del conocimiento que tenemos, sino porque el experimento implica siempre experimentar un acontecimiento (IAZZETTA, 2017, p.32-33).
} 
proposto ao termo, toda arte é experimental. E como tal, deveria ser considerado um atributo artístico geral, assim como a criatividade, a expressividade, a dramaticidade etc.

Arte experimental ou música experimental não determinam portanto gêneros específicos, mas representam uma atitude diante da produção artística na qual o caráter exploratório é parte, de maneira intensa, dos processos criativos e da poética dos trabalhos realizados. Compreendido desta maneira, o experimentalismo é uns dos aspectos que constituem e caracterizam a produção artística, que a faz relevante como experiências estéticas que vão além da reprodução de fórmulas, ações e técnicas. Assim pode-se traçar uma relação entre o experimentalismo e a relevância artística: o experimentalismo seria uma qualidade potencializadora do projeto artístico; sem investigação e sem experimentalismo, uma determinada obra de arte se aproxima daquilo que é banal e ordinário (IAZZETTA, 2017, p.35-36 - tradução minha ${ }^{4}$ ).

Uma das minhas preocupações durante a presente pesquisa foi aplicar essa atitude experimental no estudo de músicas paraguaias. Desenvolvi processos de criação a partir de minhas referências paraguaias. Realizei análise e seleção de elementos musicais com os quais trabalhei diversas abordagens de improvisação com a Orquestra Errante. Estudei as imagens culturais impressas em algumas das letras das músicas, em especial as que se referem às disputas político-econômicas e à figura feminina, das quais levantei reflexões sobre a cultura paraguaia e sua história. Além disso, a partir dessas questões levantadas, criei junto com colegas da KairosPania Cia. Cênico Sonora e da Orquestra Errante, performances que foram apresentadas dentro e fora da universidade. E compus uma peça cuja gravação envolveu colegas músicos do Paraguay e da Orquestra Errante.

As perspectivas de investigação em artes que acessei nos grupos de pesquisas NuSom, Orquestra Errante e Sonora, me permitiram uma abordagem crítica da música paraguaia e me incentivaram a explorar as possibilidades sonoras de determinados materiais musicais ou mesmo ideias musicais. Os resultados artísticos - que são uma parte não

\footnotetext{
${ }^{4}$ No original: Arte experimental o música experimental no determinan por lo tanto géneros especificos, pero representan una actitud delante de la producción artística en que el carácter exploratorio es parte, de manera intensa, de los procesos creativos y de la poética de los trabajos realizados. Comprendido de esta manera, el experimentalismo es uno de los aspectos que constituyen y caracterizan la producción artística, que la hace relevante como experiencia estética que va allá de la reproducción de fórmulas, acciones y técnicas. Se puede entonces trazar una relación entre experimentalismo y relevancia artística: el experimentalismo sería una cualidad potencializadora del proyecto artístico; sin investigación y sin experimentación, una determinada obra de arte se aproxima a lo que es banal y ordinario (IAZZETTA, 2017, p.35-36).
} 
verbalizada das reflexões -, e os resultados acadêmicos, como os artigos publicados e comunicações em congressos da área de música, conformam o arco de trabalho que desenvolvi durante esta pesquisa.

\section{A PRESENTE PESQUISA}

Uma das principais perguntas que me guiaram nesta pesquisa de doutorado foi: Como desenvolver uma tese que alia música paraguaia e improvisação livre?

Para responder à essa pergunta, minha abordagem inicial foi tomar emprestado da Física, como uma espécie de chave de leitura, o conceito de interferência que se observa na "Experiência da Dupla Fenda", proposto pelo físico Thomas Young (1773-1829). O cientista ficou famoso ao expor, em 1801, à Royal Society "um trabalho no qual demonstrava experimentalmente a interferência da luz, fornecendo, desta maneira, uma base experimental para a Teoria Ondulatória da Luz" (BRAUN, BRAUN, 1994, p.184). Na "Experiência da Dupla Fenda" se observa os comportamentos gerados pela sobreposição de ondas de luz que podem resultar em uma espécie de reforço quando as luzes combinam, se somam, mas também podem ter um caráter de cancelamento quando não combinam.

No que se refere à interferência, as ondas que se superpõem provêm de fendas diferentes, enquanto que para difração, as ondas que se superpõem provêm de diferentes partes de uma mesma fenda. Tanto num caso quanto no outro, esta superposição resulta numa interferência que poderá ser construtiva, destrutiva ou numa situação intermediária entre estas anteriores (BRAUN, BRAUN, 1994, p.186).

Ao presente estudo interessa do conceito de interferência, a ideia do caráter duplo de reforço ou cancelamento, o que pode ser observado nas questões sociais, identitárias,

\footnotetext{
${ }^{5} \mathrm{Na}$ experiência realizada pelo físico Thomas Young se utilizam três anteparos. O primeiro contém um orifício onde ocorre a difração da luz incidida. No segundo, com dois orifícios postos lado a lado, ocorrem novas difrações. Já no terceiro se observam as manchas de luz causadas pelas interferências das ondas resultantes da segunda difração, contendo regiões mais iluminadas (interferências construtivas) e regiões menos iluminadas (interferências destrutivas).
} 
culturais e musicais quando pensamos nas "luzes" oriundas do Brasil e do Paraguay, quando entram em contato, mas também quando as "luzes" são, por um lado, a música paraguaia e, por outro, a Livre Improvisação, dentre vários outros encontros de "luzes" que se reforçam e/ou se cancelam mutuamente. Essas potencialidades pude observar, por exemplo, na fricção entre trocas e negação culturais nas regiões de fronteira; na análise de músicas paraguaias que se tornaram famosas ao ponto de ganharem versões em português, sendo que várias das traduções das letras do guarani para o português modificam substancialmente seu conteúdo e a própria articulação musical junto com a síncopa original; nas imagens sobre a mulher paraguaia e sua relação com a história em ambos os países; e mesmo nas visões pejorativas sobre o Paraguay que tenho vivenciado nesses quase quinze anos de residência no Brasil.

Apesar disso, penso ser importante destacar que o objetivo dessa pesquisa é utilizar da "lente" da interferência para me ajudar a iluminar e desenvolver questões fundamentais na minha trajetória: a música paraguaia e os processos de pesquisa e criação da Orquestra Errante e do NuSom. Não pretendo realizar qualquer tipo de "reparo" histórico, ou mesmo quantificar e qualificar as diferenças e aproximações no que se refere à interpretação tradicional da música paraguaia por músicos brasileiros.

A ideia de interferência aparece nas propostas com referências paraguaias que realizei junto com a Orquestra Errante, por exemplo, na medida em que se intercalaram momentos de interação para a sustentação de estados provisórios (interferências construtivas) com outros de difusão, movimento e exploração (interferências destrutivas).

Tanto num momento como no outro as referências sugeridas se encontram em friç̧ão com as biografias pessoais - com as referências que cada participante carrega na sua própria bagagem cultural. No processo de Livre Improvisação, esses elementos de pessoalidade são o fundamento no qual se ancora o processo de criação. O Prof. Rogério Costa explica:

São os componentes históricos que incidem diretamente na performance, pois condicionam a atuação dos músicos. Esses componentes históricos, preexistentes, são as condições necessárias e suficientes para a atuação. Eles delineiam uma espécie de virtualidade 
de atitudes possíveis, são verdadeiros reservatórios de procedimentos (COSTA, 2016, p.36).

O Prof. Costa também aproxima a Livre Improvisação com as ideias de jogo, em especial o conceito de "jogo ideal" formulado por Deleuze. Nele todas as jogadas são possíveis e cada lance inventa suas próprias regras pois não há regras preexistentes.

Assim seria também a improvisação livre: um jogo dos problemas e da pergunta e não mais do categórico e hipotético. Nesse sentido, o jogo ideal e a Livre Improvisação poderiam então ser relacionados com a atividade do pensamento. 0 jogo ideal seria, portanto, o próprio jogar em que ainda não se formalizaram regras. Nesses termos, essa pode ser considerada a principal diferença entre a improvisação idiomática (jogo com regras) e a proposta de uma improvisação não idiomática (jogo ideal) (COSTA, 2016, p.28).

Me parece potente explorar referências de músicas paraguaias - que contêm seus contextos, sua carga histórica, suas regras internas -, em procedimentos de Livre Improvisação - nos quais os elementos se relacionam em outra perspectiva de liberdade. As interferências acionadas nesse encontro iluminam novas possibilidades de pesquisa e de criação para repertórios tradicionais e populares, como também permitem aportar outras perspectivas para entrar em contato com as especificidades da história e cultura do Paraguay.

No meu trabalho, as interferências entre referências paraguaias e procedimentos experimentais de criação explorados em ambos os grupos (NuSom e Orquestra Errante) criam uma zona de atrito, reflexão e movimento de onde retiro questões sobre linguagem e territórios artísticos, composição e improvisação grupais, a utilização de referências e diretrizes nos processos criativos, tudo isso de forma a alimentar de certa maneira novos processos criativos com os grupos, o que resultou na criação de performances apresentadas dentro e fora da universidade. De forma complementar, também fez com que eu pudesse revisitar alguns aspectos da história e cultura paraguaia, incitado pelos estudos sócio-históricos desenvolvidos para a criação das performances. Para apresentar as reflexões depreendidas neste estudo, organizei o trabalho em quatro capítulos. No primeiro me dedico a apresentar os processos de Livre Improvisação. No segundo, coloco em prática a exploração de referências paraguaias em jogos de improvisação com a Orquestra Errante. No terceiro, descrevo e discuto como elementos da cultura paraguaia se tornaram disparadoras para a criação de 
performances com a Orquestra Errante e KairosPania Cia. Cênico Sonora. No quarto e último capítulo, descrevo os processos de criação que resultaram na gravação de suas músicas.

\section{METODOLOGIA DE TRABALHO}

Os caminhos que percorri na execução deste trabalho dialogam bastante com a premissa de investigação artística proposta pelo Prof. Zamboni, já citado anteriormente, e que retomo aqui. As hipóteses levantadas bem como os resultados obtidos em investigações artísticas têm relações diferentes quando comparadas com as pesquisas em ciência. Primeiramente, tanto em arte quanto em ciência, a proposição de hipóteses está vinculada à inserção do objeto de estudos dentro de marco teórico referencial:

Enquanto a função da hipótese em ciência é fornecer a conexão entre a teoria e a investigação e se constituir como meio pelo qual a teoria intervém na investigação, em arte, a hipótese não assume forma tão rigorosa, sendo mais um desejo e uma expectativa do que poderá ocorrer em termos de resultado final. A hipótese em qualquer pesquisa no campo artístico, não tem o mesmo grau de vinculação à teoria que na pesquisa científica, denotando a conscientização do pesquisador em face do processo de investigação em vias de se realizar (ZAMBONI, 1998, p.53).

Que "não tem o mesmo grau de vinculação à teoria" significa que na investigação artística contamos com um marco teórico referencial, ao mesmo tempo em que as reflexões tecidas durante os processos de criação devolvem reciprocamente dados para a matriz de pensamento sobre a investigação artística. Ambas estão em movimento e se alimentam mutuamente. Devolvemos à teoria ferramentas de pensamento que construímos durante nossa investigação, que eventualmente podem servir de referências para outras investigações.

Essa perspectiva sobre o que se espera da uma pesquisa artística também reverbera na forma como se observam os resultados e suas possíveis interpretações, como indica o Prof. Zamboni: 
A pesquisa em ciência procura sempre restringir ao mínimo as interpretações possíveis. A ciência busca uma resposta única aos problemas por ela investigados, por meio de um fecho conclusivo, cabendo ao receptor da pesquisa aceitar as conclusões ou não, e em caso negativo, ele não estará contestando a ciência, mas o autor, o método ou o quadro teórico utilizado. Em resumo, a conclusão de uma pesquisa científica deve apontar para resultados os mais unívocos possíveis, para os quais a interpretação também deverá tender a ser única. A ciência visa, em suma, diminuir os riscos de resultados e conclusões multinterpretativas (ZAMBONI, 1998, p.58).

A partir das colocações do pesquisador, entendo que as conclusões de uma pesquisa artística não podem ser apresentadas como fatos inequívocos ou "verdades" descobertas. As conclusões são produzidas no plural e dependem do diálogo com os/as interlocutores/as que a interpretam.

A interpretação dos resultados da pesquisa em arte não converge para a univocidade, mas para a multivocidade, uma vez que cada interlocutor deverá fazer a sua interpretação pessoal e proceder uma leitura subjetiva para analisar o resultado da pesquisa contido na própria obra de arte. Diferentemente da ciência, a arte tem um caráter pessoal de interpretação, garantido pela plurissignificação da linguagem artística (ZAMBONI, 1998, p.59).

A respeito dos métodos de observação, Zamboni também nos alerta da importância de entender que as perspectivas de observação dos resultados estão relacionadas aos paradigmas que envolvem cada pesquisa artística. Os processos de percepção e comunicação se diferenciam não pelas individualidades características de cada ser humano, mas sim pelos paradigmas que instruem o olhar de cada pesquisador/a (ZAMBONI, 1998).

O que é valido e permitido para uma atividade circunstanciada por um paradigma, pode não ser para outra. Nos paradigmas da ciência, a percepção e a representação da realidade seguem normas muito mais limitadas de atuação do que nos paradigmas artísticos, que induzem e forçam a observação de maneira muito mais complexa e profunda (ZAMBONI, 1998, p.55).

Nesse sentido, o Prof. lazzetta (2017) aponta a necessidade de entender que a natureza de uma pesquisa artística é diferente da natureza de uma pesquisa científica, e por isso não corresponderia tentar observar os resultados através de métodos de argumentação dedutiva e indutiva - que supõem dados quantificáveis e qualificáveis. 
A prática musical é direcionada para a criação de singularidades, enquanto a prática científica geralmente busca a descoberta de leis e regularidades. Sim, podem-se traçar aspectos gerais ou comuns nas obras de um determinado gênero ou época em particular. Mas essas generalidades evidenciam a distância entre a arte como objeto genérico de pesquisa e a arte como objeto estético, cujo valor reside naquilo que a distingue de outros objetos do cotidiano, e que produz sentido a partir das diferenças (IAZZETTA, 2017, p.25 - tradução minha6).

Ainda nessa questão, o Prof. lazzetta nos alerta sobre as iniciativas que resolvem apenas parcialmente a fricção a respeito das metodologias de pesquisa artística dentro da instituição acadêmica. Nesse sentido, existe um esforço por equilibrar as forças (de fomento, de relevância, de aceitação) que conduzem as pesquisas, invocando a pertinência de considerar a produção artística como produção de investigação. O termo performantive research, cunhado pelo pesquisador Brad Haseman (2006), se refere a essa perspectiva. Para o Prof. lazzeta:

Compartilhando semelhanças com os métodos qualitativos e quantitativos tradicionalmente usados tanto nas ciências naturais como nas ciências humanas, essa vertente expressa a contingência das práticas atuais voltadas para a ação e para os processos de construção do conhecimento (IAZZETTA, 2017, p.39 - tradução minha7).

A ressalva que o Prof. lazzetta realiza é que - ainda partindo da concepção de que a arte é, por si mesma, um produto de geração de conhecimento e, portanto, os processos de criação e os objetos artísticos devem ser considerados como resultados ao invés de objetos de investigação -, essa perspectiva esbarra na dificuldade de propor formas de avaliação objetivas e quantificáveis semelhantes aos que se praticam nas ciências duras (IAZZETTA, 2017).

\footnotetext{
${ }^{6}$ No original: La práctica musical es direccionada para la creación de singularidades, mientras la práctica científica generalmente busca el descubrimiento de leyes y regularidades. Es claro que se puede trazar aspectos que son generales o comunes en las obras de un determinado género o época en particular. Pero estas generalidades evidencian la distancia entre el arte como objeto genérico de investigación y el arte como objeto estético, cuyo valor reside en aquello que la distingue de otros objetos del cotidiano, y que produce sentido a partir de las diferencias (IAZZETTA, 2017, p.25).

${ }^{7}$ No original: Compartiendo semejanzas con los métodos cualitativos y cuantitativos tradicionalmente usados tanto en las ciencias naturales cuanto en las ciencias humanas, esa vertiente expresa la contingencia de las prácticas actuales direccionadas para la acción y para los procesos de construcción de conocimiento (IAZZETTA, 2017, p.39).
} 
Nesse sentido, o Prof. Zamboni também aponta para a dificuldade de adequar a pesquisa artística aos métodos de observação que visam precisão e exatidão nos resultados:

Em ciência são inúmeros e incontáveis os estudos que versam sobre a metodologia científica. Para cada área científica existem proposições de modelos metodológicos que se diferenciam entre si, visando sempre uma forma adequada para cada área, levando sempre em consideração as suas especificidades. À medida que se caminha das áreas tidas como exatas para as ciências humanas e sociais, vai se tornando mais difícil a utilização de parâmetros quantificáveis, e se adentrando em metodologias mais complexas com resultados menos exatos. Possivelmente a arte é a área que está no fim dessa sequência de subdivisões do conhecimento humano, onde é mais difícil qualquer quantificação (ZAMBONI, 1998, p.48).

A procura de objetivos predeterminados, como ocorre nas abordagens dedutivas e indutivas, visam construir propostas que sejam quantificáveis e qualificáveis, "aumentando o conhecimento sobre um determinado objeto e, eventualmente, chegando a proposições que podem ser consideradas como verdades" (IAZZETTA, 2017, p.44 - tradução minha $^{8}$ ), no entanto, essas abordagens estão distantes da natureza das produções artísticas, como indica o Prof. lazzetta:

Agora, não tem como orientar uma produção artística a partir da busca de verdades, portanto, não se pode esperar que a investigação artística seja conduzida pelos mesmos preceitos que a investigação em ciências. Apesar disso, existe um ponto em comum nos modos de argumentação destes dois campos: a investigação em ambos, arte e ciência, parte de um processo abdução (IAZZETTA, 2017, p.44 - tradução minha9 ${ }^{9}$.

O Prof. Iazzetta utiliza o conceito de abdução, formulado pelo filosofo Charles Sanders Peirce (1839-1914) para se referir ao processo de inferência a partir do qual formulamos hipóteses sobre as coisas e produzimos ideias. Nas palavras de Peirce:

\footnotetext{
${ }^{8}$ No original: aumentando el conocimiento sobre un determinado objeto y, eventualmente, llegando a proposiciones que pueden ser consideradas como verdades (IAZZETTA, 2017, p.44).

${ }^{9}$ No original: Ahora, no hay como orientar una producción artística a partir de la búsqueda de verdades, por lo tanto, no se puede esperar que la investigación artística sea conducida por los mismos preceptos que la investigación en las ciencias. A pesar de esto, hay un punto común en los modos de argumentación de estos dos campos: la investigación en ambos, arte y ciencia, parte de un proceso de abducción (IAZZETTA, 2017, p.44).
} 
A sugestão por abdução vem com um flash. É um ato de insight (...) É verdade que os diferentes elementos da hipótese já estavam em nossas mentes antes; mas é a ideia de juntar o que nunca sonhamos reunir que projeta a nova sugestão antes de nossa contemplação (PEIRCE apud IAZZETTA, 2017, p.45, grifo no original - tradução minha ${ }^{10}$ ).

A partir da perspectiva que o Prof. lazzetta aponta, entendo que o processo abdutivo me permite projetar interferências entre questões de música paraguaia (elementos culturais, elementos musicais, ideias sonoras e imagens) e os processos de criação e experimentação artística cultivados nos grupos de estudos Orquestra Errante e NuSom. As interferências entre referências paraguaias e experimentalismo fomentam um ambiente potente de criação na medida em que aciona materiais musicais retirados de um contexto específico e as coloca em jogo nos processos de Livre Improvisação. Não se trata de um processo de "idiomatizar" as improvisações com a Orquestra Errante, mas sim da exploração de processos criativos a partir da interferência de referências paraguaias (culturais, imagéticas, sonoras) nas improvisações.

Assim, o processo abdutivo se apresenta como um método potente para pesquisas que envolvem processos criativos e de experimentação artística, pois permite formular respostas sem necessariamente contar com um problema objetivo que as demande, isto é, permite a projeção de expectativas.

\begin{abstract}
Essas soluções não são fruto do acaso, mas emergem do conhecimento acumulado de quem as cria. Esse processo ainda não pode ser totalmente formalizado, a tendência é que quando concretiza em realizações práticas, se cristalize, gerando procedimentos, conceitos e formulações que podem, então, ser confrontados com outras práticas criativas, com outros objetos artísticos, e com outras formas de conhecimento. Assim, o trabalho experimental em arte nem sempre procura objetivar um resultado que pode ser determinado de antemão, mas é dele que os resultados - obras, conceitos, processos, técnicas emergem, se transformam e se renovam (IAZZETTA, 2017, p.45-46 tradução minha ${ }^{11}$ ).
\end{abstract}

\footnotetext{
${ }^{10}$ No original: La sugerencia por la abducción viene como un flash. Es un acto de insight (...) Es verdad que los diferentes elementos de la hipótesis ya estaban en nuestras mentes antes; pero es la idea de juntar lo que nunca soñamos reunir que proyecta la nueva sugerencia ante nuestra contemplación (PEIRCE apud IAZZETTA, 2017, p.45).

${ }^{11}$ No original: Esas soluciones no son fruto de una mera casualidad, pero emergen del conocimiento acumulado de quien la crea. Todavía no se puede formalizar totalmente ese proceso, la tendencia es que al ser concretizado en realizaciones prácticas, él se va cristalizando, generando procedimientos, conceptos
} 
No presente trabalho essas perspectivas são acionadas na medida em que proponho interferências entre referências paraguaias e os procedimentos de criação que estudamos na Orquestra Errante. Nesse sentido os conceitos trabalhados pelo Prof. Rogério Costa, como: jogo, território e diluição de fronteiras, base de conhecimento e referentes, comprovisação, são recursos que me permitem projetar processos de criação contemporâneos - exploradas pela Orquestra Errante -, a partir do estudo crítico de referências paraguaias.

Também nesse sentido, a própria estrutura da tese dialoga com os apontamentos dos professores citados, pois o desenvolvimento da pesquisa foi realizado de maneira "espiral" passando pelos estágios de pesquisa (leituras, análises, seleção), experimentação (propostas de improvisação, criação de performances), reflexão e escrita (pensar música paraguaia a partir da lente da Livre Improvisação).

As propostas de improvisação com a Orquestra Errante exploraram a utilização de referências paraguaias. Posso dizer que se configuram como exercícios sobre possibilidades estéticas, que depois alimentaram os processos de criação das performances juntando a Orquestra Errante com a KairosPania Cia. Cênico Sonora. Nesse sentido, a perspectiva crítica sobre aspectos culturais que observei nas músicas paraguaias trabalhadas nas performances, apontam assuntos pertinentes não só ao Paraguay e sua relação com Brasil, mas de maneira geral, também diz respeito à nossa condição sul-americana.

y formulaciones que pueden, entonces, ser confrontados con otras prácticas creativas, con otros objetos artísticos, y con otras formas de conocimiento. Así, el trabajo experimental en arte no siempre busca objetivar un resultado que puede ser determinado de antemano, pero es a partir de él que resultados obras, conceptos, procesos, técnicas - surgen, se transforman y se renuevan (IAZZETTA, 2017, p.45-46). 


\subsection{LIVRE IMPROVISAÇÃO: A REFORMULAÇÃO DA CRIAÇÃO COLETIVA}

Do ponto de vista histórico, os precedentes das práticas que hoje são chamadas de "Livre Improvisação" remontam às reconfigurações sociais e econômicas entre as décadas de 1950 e 1960 nos polos culturais norte americano e europeu. As ações políticas pela luta de direitos humanos nos Estados Unidos naqueles anos e que ocorreram de forma análoga na Europa - com ápice nos protestos em Paris em 1968 -, acabaram impulsionando o desenvolvimento de modelos de relações musicais com ênfase nas ideias de liberdade e coletividade a partir de práticas radicais de criação musical. Como indica o pesquisador Manuel Falleiros (2013), os/as músicos/musicistas engajados/as com essas ideias passaram a "formular suas composições como produto do fazer coletivo e rarefazer seu poder individual. Diminuindo a precisão das prescrições musicais em suas composições, legaram ao intérprete a participação no processo composicional" (FALLEIROS, 2013, p.2). Nesse sentido, o Prof. Rogério Costa (2016) acrescenta que as ideias musicais que emergiram naquele contexto que se alinhavam com "a crescente dissolução e permeabilidade das fronteiras entre os 'idiomas' ou sistemas musicais, particularmente após o esgotamento e a superação do tonalismo que passa a ser entendido como um entre vários sistemas possíveis de organização do material sonoro" (COSTA, 2016, p.1-2). A partir de então, diversas propostas artísticas embarcaram na exploração das possibilidades de criação que a Livre Improvisação enseja:

A livre Improvisação é a música que contempla amplamente as particularidades da era pós-moderna. A relação com o fazer em tempo presente, fluxo imediato do pensamento à ação criadora, a instabilidade 
no percurso, o encontro de territórios antes duramente delimitados, são apenas alguns exemplos desta proximidade (FALLEIROS, 2013, p.3).

De modo similar, os estudos acadêmicos sobre essa prática também vêm crescendo, sendo o trabalho do Prof. Rogério Costa uma das referências principais no Brasil. Na abordagem de estudos do Prof. Costa, dentro da qual desenvolvi a presente pesquisa:

[A Livre Improvisação] é pensada como resultado de uma ação criativa, coletiva e intencional de um grupo específico de músicos que se configuram assim, enquanto performers criadores. Nesse sentido, desde já é preciso afirmar que a livre improvisação se coloca como uma proposta estética e de ação musical (COSTA, 2016, p. XXI - grifo no original).

Essa é a perspectiva sob a qual também atua a Orquestra Errante - um grupo de estudos sediado na USP que funciona como laboratório prático para pesquisas sobre improvisação, coordenado pelo Prof. Rogério Costa. A partir das reflexões a respeito da prática da Livre Improvisação com a Orquestra Errante, fomos entendendo e sistematizando alguns pressupostos que formam uma espécie de fundamento da nossa prática, entre eles, por exemplo, está a ideia de que é possível utilizar livremente todo e qualquer som no intuito de construir um fluxo sonoro em tempo real. Também formulamos a ideia de que o agenciamento desse fluxo - os tempos, as proporções, os reforços e os desvios - devem ocorrer de maneira coletiva e colaborativa entre as pessoas participantes.

Para nós, integrantes da Orquestra Errante, a prática da Livre Improvisação se apresenta como um processo criativo sem restrições musicais previamente estabelecidas, a não ser a disposição dos/as instrumentistas em fazer música juntos/as. Nessa perspectiva, a Livre Improvisação é entendida como um processo colaborativo de criação e expressão artística que se sustenta na concretude do momento presente e no investimento nas relações ativadas no devir do jogo. Trata-se de criação e fruição estética que se ancora no processo lúdico e interativo que a prática incita a partir do livre relacionamento de sons e energias. Ou seja, ela requer aquela atitude experimental (IAZZETTA, 2017) citada anteriormente, de manipulação sonora para além das referências em termos de notas e notação musicais tradicionais (COSTA, 2003, 2016; FALLEIROS, 2012). O Prof. Costa explica: 
Outras linhas de força extramusicais importantes para o sucesso dessa proposta são as qualidades necessárias para o convívio - que requer uma dose de disciplina individual - entre os músicos: humildade, generosidade, curiosidade, sensibilidade e paciência. Trata-se de uma ética coletiva. Assim se constrói não uma linguagem conscientemente articulada, mas, passo a passo - cada passo por uma pessoa diferente -, uma coisa simbiótica. $O$ todo excede a soma das partes individuais. Um grupo com esse tipo de funcionamento desenvolve uma segurança na liberdade: todos estão prontos para dialogar com o imprevisto (COSTA, 2016, p.11).

As possibilidades de pesquisa e criação da Orquestra Errante me interessam pois as ideias de música que permeiam nossa prática diluem as fronteiras entre as categorizações de gêneros musicais enquanto idiomas herméticos. No presente estudo, exploro processos de criação a partir das interferências entre referências paraguaias e as ideias de liberdade e coletividade que cultivamos na Orquestra Errante - o que não significa que as criações sejam isentas de friç̧ões pois também interferem nesse processo as referências particulares de cada participante. Nesse sentido, o Prof. Costa indica que "é impossível partir do grau zero. No mínimo estarão lá presentes, como linhas de força, os idiomas, mecanismos e sistemas que atravessam a biografia musical de cada membro do grupo de improvisação" (COSTA, 2016, p.6).

Sendo assim, improvisação "livre" existe? Sim e não.

Ou melhor, só existe relativamente. Há ao menos uma (ou mais) vontade aplicada a um determinado plano ${ }^{12}$ de imanência/composição (...) A improvisação é um ato coletivo dirigido a um certo ambiente territorializável no próprio ato. Pressupõe vários atos de vontade que visam dar consistência a vários elementos e componentes. Estes elementos e componentes - o físico/corpo do músico, os idiomas a que foi submetido, sua biografia musical e pessoal - já delimitam as possibilidades. Os próprios procedimentos (variar, desenvolver, imitar,

\footnotetext{
12 Para o Prof. Rogério Costa: “o plano é, no caso da livre improvisação, um bloco de espaço-tempo indefinível em seus contornos onde acontecem as atuações - agenciamentos -dos improvisadores e onde, por conseguinte, coexistem diferentes energias, atitudes singulares, pensamentos, conexões, histórias pessoas e coletivas. Ele é o 'horizonte de acontecimentos' da livre improvisação que emerge enquanto resultado (em movimentos pois a performance é uma prática) de lances livres e casuais, de interações e conexões paralelas (polifônicas), a-paralelas (melodias acompanhadas), transversais (memórias curtas, médias e longas), verticais (harmônicas) e horizontais (melódicas). O plano é que possibilita o movimento da performance. Ela se dá no interior do plano, mas não se confunde com ele. Uma performance depende da existência deste plano que dever ser preparado a partir do desejo, da disponibilidade e da necessidade (COSTA, 2016, p.38-39).
} 
contrastar, transpor, etc.) que compõem o pensamento musical são ritornelos que traçam caminhos de consolidação (COSTA, 2003, p.169).

Existe o conjunto de procedimentos que inventamos, exercitamos e transformamos ao longo dos encontros semanais da Orquestra Errante, e que podem ser pensados como uma espécie de jogos musicais. Aliás a ideia de jogo é recorrente para a Livre Improvisação pois a premissa de criação grupal de um fluxo sonoro e a manutenção (e desvios) desse fluxo se desdobram na sensação de imersão que alimenta a si mesmo, em outras palavras, "a indicação de continuidade para além do previsto e através do imprevisto estabelece uma ideia de jogo para a Livre Improvisação" (FALLEIROS, 2012, p.19). Um processo experimental no qual as habilidades técnicas não desaparecem, mas mudam de contexto. Utilizando um outro termo fundamental para este estudo, se desterritorializam.

Deixa[m] de apoiar-se em procedimentos estruturados e sedimentados para emergir da própria experiência do que possa parecer, não representa necessariamente um rompimento com as técnicas tradicionais, mais uma compreensão e utilização dessas técnicas por meio de um jogo. Experimentar é testar a falibilidade daquilo que conhecemos, em última instância da própria técnica" (IAZZETTA, 2012, p.229).

A ideia de jogo na Livre Improvisação é apontada na tese (2003) do Prof. Costa desde uma perspectiva que a relaciona com o conceito de jogo ideal formulado pelo filósofo francês Gilles Deleuze (1925-1995).

Deleuze nos diz que não basta opor um jogo 'maior' ao jogo menor do homem, nem um jogo divino a um jogo humano. Para instaurar este jogo ideal é preciso imaginar outros princípios, aparentemente inaplicáveis, mas graças aos quais o jogo se torna puro. Ao contrário do jogo 'menor', neste não há regras preexistentes. Todas as jogadas são possíveis pois cada lance inventa suas regras. Sem a intenção de dividir o acaso em um número de jogadas distintas, o conjunto de jogadas afirma todo acaso e o ramifica em cada jogada (...) O jogo ideal e a livre improvisação são como a realidade do próprio pensamento. Este conceito de jogo ideal se opõe ao conceito genérico estabelecido por Huizinga que diz que uma das principais características positivas do jogo é que ele cria ordem e é ordem (COSTA, 2003, p.41 - grifo no original). 
No contexto da Livre Improvisação dispensam-se parâmetros específicos para avaliar um determinado som como "certo" ou "errado", dado o pressuposto de liberdade de ação que essa prática carrega.

(...) não há critérios de julgamento estético já que o objetivo é instaurar um campo de jogo democrático e não hierarquizado, um ambiente fértil de experimentação que se sustente a partir do desejo, da escuta e da interação, e onde o que importa é a continuidade do jogo (COSTA, 2018, p.179).

Essa outra perspectiva a respeito do "certo" e do "errado", junto com as ideias de jogo e posturas de ação me ajudaram a tecer conexões entre a Livre Improvisação e o Clowning, tema que tratei na minha dissertação de mestrado. Ali, descobri permeabilidades entre as duas práticas artísticas, suas conexões e diferenças, que serviram para pensar e propor estratégias de interação colaborativas. A relação do corpo na performance; o estado de atenção e prontidão acentuadas; a irrelevância (ou a potência) do erro e a liberdade de afrontar o ridículo são alguns dos pontos que observei naquele estudo, e que formam uma espécie de sedimento sobre o qual amplio as conexões da Livre Improvisação, no caso da presente pesquisa, com minhas referências paraguaias.

Nas propostas artísticas em que a criação e a execução se misturam no devir do acontecimento, a ênfase no processo, no "como se faz", ilumina a importância das dimensões físicas, corporais e emocionais dos gestos. Nesse contexto o conceito de performance não diz respeito a questões como desempenho ou rendimento, mas está atrelado a ideia da presença de um corpo realizando atos em situações definidas (ZUMTHOR, 2007) - em outras palavras, algo precisa estar acontecendo naquele instante, naquele local (COHEN, 2013). O pesquisador Falleiros (2018) adverte a respeito da vertente histórica que relaciona a improvisação em oposição à performance, pois entende "a performance a partir da ideia de execução, fidelidade e virtuosismo" (FALLEIROS, 2018, p.196). No caso específico da Livre Improvisação, a ênfase no processo, no como acontecem as relações, reconfigura a ideia de resultados pois a expectativa já não se direciona à "correta interpretação" de alguma questão elementar. É nesse sentido que a ênfase no processo também diz respeito a ênfase no instante presente e à atenção ampliada que se requer, como explica o Prof. Costa: 
A escuta tem uma função diferente daquela que se espera nas práticas interpretativas. Aqui ela não serve para medir, quantificar e comparar resultados atingidos com resultados almejados. Nesse contexto de experimentação, criação coletiva e interação, a escuta é um dos principais fundamentos. É através da escuta, pensada num sentido amplo - não só coclear, mas também visual, tátil, olfativa, emocional que o ambiente se ativa. A escuta é, ela mesma, uma forma de pensamento musical que se configura na interação entre os elementos do ambiente (COSTA, 2018, p.181).

Na presente pesquisa selecionei canções paraguaias, analisei as letras e seus elementos musicais, procurei conhecer os contextos em que foram escritas, extraí delas questões que me pareceram relevantes e potentes para falar do Paraguay e das relações com o Brasil. De certa maneira, tentei escutar e documentar o que aqueles materiais queriam me dizer.

Posteriormente, e munido dessas informações, dirigi encontros com a Orquestra Errante onde trabalhamos elementos musicais paraguaios mediante propostas de improvisação, investigando elementos como síncopas e trechos de melodias, bem como expus o que havia pesquisado sobre o contexto histórico e social das músicas selecionadas como referência para desenvolver as propostas.

Em complemento a esses levantamentos, apresentações e jogos realizados nos encontros regulares da Orquestra Errante, propus processos criativos visando a criação e apresentação de performances dentro e fora da universidade. As performances foram concebidas de maneira colaborativa pelos/as integrantes dos grupos Orquestra Errante e KairosPania Cia. Cênico Sonora. Esta última, como o nome sugere, é uma trupe que transita tanto entre as artes cênicas e as artes sonoras, dialogando ainda com as artes plásticas e audiovisuais. Parte de seus/suas integrantes também participam do NuSom e da própria Orquestra Errante.

As performances criadas pela Orquestra Errante e a KairosPania Cia. Cênico Sonora apresentadas neste trabalho, acionaram referências paraguaias, tanto no sentido de materiais musicais (guarânia "Lejania”, compuesto "Mateo Gamarra") como simbólicas (apagamentos de narrativas, machismos e feminismos).

As interferências decorrentes desses materiais (sonoros, culturais, conceituais) colocados em jogo em processos de Livre Improvisação também rementem à ideia de 
dentro e fora $(\mathrm{I} / \mathrm{O})$, envolvendo idiomas, memórias, fronteiras e relações entre improvisação livre e idiomática.

\subsection{EXPRESSÃO SONORA: ENTRE AS EXPERIÊNCIAS ACUMULADAS E O ATRAVESSAMENTO DE OUTRAS REFERÊNCIAS}

Como já mencionei, a Orquestra Errante se reúne semanalmente há mais de dez anos.

O grupo está aberto ${ }^{13}$ a receber qualquer pessoa disposta a se engajar com nossas propostas. Nosso único requisito é a participação nos encontros com alguma regularidade. Algumas pessoas passam vários anos trabalhando suas pesquisas no grupo até a conclusão de seus estudos, e após formados/as, se distanciam da universidade e do grupo, o que é comum. Nesse sentido também é comum que antigos/as participantes visitem esporadicamente os encontros e até participem de performances e concertos. Ademais, o grupo conta com integrantes bem assíduos/as, que iniciam pesquisas na graduação e continuam a trabalhá-las na pós-graduação, como é o meu caso. Indico tudo isso porque a incorporação de procedimentos, estratégias e ideias de músicas experimentados ao longo dos anos se sedimentam como conhecimentos adquiridos "pela orquestra", de modo que passam a compor a "cara", o "estilo" da própria Orquestra - ela nada mais é do que o resultado do que propõem ou propuseram seus integrantes ao longo do tempo.

Pode-se dizer que a orquestra funciona com um organismo vivo que mantém coesão devido à presença mais ou menos assídua de um centro número de integrantes e da continuidade das pesquisas práticas e teóricas sobre a improvisação que são ali desenvolvidas. Em vários sentidos e aspectos, neste projeto se equilibram as ideias de impermanência (adaptabilidade, informalidade, flexibilidade, porosidade e maleabilidade) e permanência, já que não se trata de um ambiente totalmente aberto e propositalmente desestruturado no qual,

13 “(...) não se exige nenhum tipo de inscrição ou matrícula, não há processos de seleção ou de avaliação, notas ou lista de presença" (COSTA, 2020, p.317). 
a cada ensaio semanal o grupo se modifica totalmente (COSTA, 2020, p.318).

A partir dessa relação entre permanência e impermanência, observo que as interferências entre a repetição de certos procedimentos de interação e a biografia particular de cada participante não só se relacionam com o surgimento de algo parecido a um "estilo" na Orquestra Errante, mas também colocam em movimento os conhecimentos, habilidades e ideias, ou seja, a própria biografia de seus/suas participantes. Pois a dupla relação entre o que permanece e o que se transforma também diz respeito a biografia musical de cada um/a.

Certamente continuo tendo uma forte relação afetiva com a música paraguaia, mas a partir da experiência com a Orquestra Errante minha relação com a música paraguaia não se concentra mais em reforçar uma tradição estabelecida, e sim em ampliar as possibilidades de leitura e escuta, de pesquisa e experimentação, enfim, de relações. Essa é a perspectiva de pesquisa e criação que descobri ao longo dos anos participando da Orquestra Errante e que hoje forma parte da minha experiência.

Nesse sentido entendo que cada músico/musicista tem sua história particular, suas experiências de vida e musicais. Delas decorrem modos particulares de lidar nos diversos contextos musicais. Esses maneirismos e jeitos de ser conformam o estilo particular, o "rosto" de cada músico/musicista, como indica o Prof. Costa:

Podemos dizer, utilizando um conceito de Deleuze que nos parece elucidar todo este processo de acumulação de características, tendências e jeitos de ser resultante da história pessoal de cada um, que o músico traz um rosto e é com base neste rosto que todo e qualquer processo de produção vai se delinear (COSTA, 2003, p.62 - grifo no original).

Por isso, no contexto da Livre Improvisação, mesmo quando se procura improvisar a partir "do nada", na verdade estaremos sempre partindo na nossa história acumulada, das nossas experiências. A liberdade total é uma ideia utópica, pois estamos condicionados/as por inúmeras camadas de experiências incorporadas. O que existe e se manifesta na Livre Improvisação é uma constante busca, uma atitude experimental e criativa. Mas nunca nos livramos de nossos corpos, de nossa história, de nossa subjetividade/singularidade. Nesse sentido, na Livre Improvisação colocamos em jogo criativo - em interferências - referências de identidades. Nas palavras do Prof. Costa: 
Esses componentes históricos, preexistentes, são as condições necessárias e suficientes para a atuação. Eles delineiam uma espécie de virtualidade de atitudes possíveis, são verdadeiros reservatórios de procedimentos. Assim, cada músico poderá ter uma série infinita de atitudes possíveis no contexto da performance real, embora essa série seja limitada às suas vivências. Um músico, ao improvisar, estará sempre 'colocando em jogo sua identidade'. Ou seja: na improvisação o músico é o meio (COSTA, 2016, p.36).

Ainda nesse sentido, o Prof. Costa relaciona a experiência acumulada com o conceito de knowledge base (base de conhecimento) e diferencia suas perspectivas quando aplicadas à Livre Improvisação e à improvisação idiomática. Esta última se relaciona com uma dimensão teórica (sistemas abstratos, regras de sintaxe) e uma dimensão prática cristalizada nas experiências significativas dos/as envolvidos/as com algum idioma particular. Já para a Livre Improvisação a base de conhecimento envolve questões para além dos territórios idiomáticos.

Nesse sentido, pode-se dizer que, para a improvisação livre, a base de conhecimento não é delimitada por uma (ou mais) linguagem musical específica, mas é constituída por todas as experiências sonoras e musicais dos improvisadores e por aquilo que está "antes e além" dessas linguagens (...).

Assim, a base de conhecimento da improvisação livre compreende um know-how que não se expressa em um idioma ou referente particular. Com relação ao improvisador livre, poderíamos dizer que a knowledge base é composta por todas as memórias musicais pessoais de longa duração armazenadas na forma de um know-how (habilidades de percepção emocionais e motoras), e de um know-what (do ilimitado universo de materiais sonoros, que precede o musical e que possibilita infinitas ampliações) (COSTA, 2016, p.195 - grifos no original).

A partir dessas colocações, resgato a importância afetiva de minhas referências paraguaias, que formam parte da minha identidade. $\mathrm{E}$ a isso somam-se as novas possibilidades de pesquisa e criação que os professores Rogério Costa e Fernando lazzeta e os grupos de pesquisa Orquestra Errante e NuSom acrescentaram na minha formação. Nesse sentido, ao se referir a identidade na música latino-americana, o pesquisador uruguaio Rubén Olivera (2019) se refere à importância do contexto de formação de cada pessoa e o relaciona com o conceito de impronta cunhado pelo zoólogo austríaco Konrad Lorenz (1903-1989). O termo impronta deriva da palavra imprinting e se refere a impressão, impresso, marca o sinal. A relação que o pesquisador 
Olivera (2019) traça se refere ao estabelecimento de vínculos duradouros com referências que ficaram impressas em cada biografia particular.

Sermos respeitosos com a impronta cultural de cada pessoa ou sociedade não quita a necessidade de tratar de entender criticamente os padrões que a gestaram e continuam construindo-a. A representação romântica dos gostos como pertencentes a uma espontaneidade natural esquece que elas se constroem condicionadas desde 0 nascimento pelas coordenadas do sistema social em que estão inseridos (OLIVERA, 2019, p.50 - tradução minha ${ }^{14}$ ).

Outro conceito que pode nos ajudar a compor essa ideia de referências e atravessamentos na construção de uma identidade nos é apresentada pelo pesquisador Evandro Higa (2013), que aciona o conceito de habitus - do sociólogo Pierre Bourdieu (1930-2002) - para indicar os contextos em que ocorrem as friç̧ões de identidades.

o habitus não é um destino (...) trate-se de um sistema aberto de disposições que estará submetido constantemente a experiências e, desse modo, transformado por essas experiências (...) as pessoas terão experiências em conformidade com as experiências que formaram o habitus dessas pessoas (...) o habitus - por ser um sistema de virtualidade - só se revela em referência a uma situação (...) é na relação com determinada situação que o habitus produz algo. Ele é semelhante a uma mola, mas é necessário um desencadeador; e, dependendo da situação, ele pode fazer coisas opostas (BOURDIEU apud HIGA, 2013, p.91 - grifo no original).

O habitus musical funciona como um "sistema de disposições duráveis e transponíveis, integra todas as experiências passadas, funcionando ininterruptamente como matriz de percepções, de apreciações e de ações" (HIGA, 2013, p.197). Nesse sentido, os pesquisadores Lilian Campesato e Fernando lazzetta (2019, p.47) apontam para a ideia de que não só criamos os objetos no mundo, mas "os objetos que estão no mundo ajudam a constituir o que somos" - também a partir do conceito de habitus de Pierre Bourdieu.

\footnotetext{
${ }^{14}$ No original: Ser respetuosos de la impronta cultural de cada persona o sociedad no quita la necesidad de tratar de entender críticamente los patrones que la gestaron y la siguen construyendo. La representación romántica de los gustos como pertenecientes a una natural espontaneidad olvida que se construyen condicionados desde el nacimiento por las coordenadas del sistema social en el que se está inserto (OLIVERA, 2019, p.50).
} 
Os habitus são um sistema de condicionamentos sociais e individuais que moldam a maneira como agimos, nossos gostos e nossos corpos. 0 que ouvimos, o que comemos, como nos vestimos, são reflexos desse sistema de condicionamentos. É ele que nos une e ao mesmo tempo nos separa, pois permite que sejam criados modos de classificação e valoração que são particulares (CAMPESATO, IAZZETA, 2019, p.47).

Conectando os pontos anteriores, neste trabalho procuro a fricção entre a atitude experimental de criação e o transbordamento das referências que me formam. E como expressão artística, na esteira da Livre Improvisação, o ato de revisitar músicas paraguaias afirma que, embora elas representem um passado, se apresentassem como algo vivo que ainda têm muito a dizer.

Esse passado é presentificado, manipulado e entra em jogo de acordo com os rumos da performance em tempo real. Há uma intencionalidade que opera a partir da memória da representação ou da memória curta aplicada aos materiais sonoros (...) De fato, o jogo da livre improvisação se dá em um plano de intensa interação e contaminação entre territórios, ou seja, os vários territórios que constituem as biografias musicais de cada músico se interpenetram e ressoam um no outro de maneiras imprevistas (COSTA, 2016, p.78).

É da necessidade de fazer de nossa biografia algo vivo e pulsante que se alimenta o presente trabalho.

\subsection{A LIVRE IMPROVISAÇÃO É CONTRA A LINGUAGEM?}

O pesquisador e guitarrista Derek Bailey foi um dos pioneiros em escrever a respeito da Livre Improvisação, comparando-a com outras formas de improvisação historicamente mais estabelecidas. No livro "Improvisation: its nature and pratice in music" (primeira edição 1980/1993), aponta o que ele entende por duas formas básicas de improvisação. Uma diz respeito às práticas musicais social e historicamente estabelecidas em determinados contextos, constituindo "idiomas" musicais. Para esse conjunto de práticas Derek Bailey (1993) utiliza o termo "improvisação idiomática". Em contraposição, na segunda forma estariam as práticas que se afastam das características que permitem justamente a percepção de idiomas musicais. Nas palavras de Bailey: 
A improvisação não idiomática tem outras preocupações e é mais comumente encontrada na chamada "livre" improvisação e, embora possa ser altamente estilizada, geralmente não está ligada à representação de uma identidade idiomática (BAILEY, 1993, p.xi tradução minha ${ }^{15}$ ).

A dualidade - idiomático, não idiomático - foi uma chave de leitura que facilitou observar as principais diferenças entre os processos de improvisação a que se relacionam determinadas práticas musicais. Nesses termos, o idiomatismo é considerado uma espécie de território compartilhado, com determinados modos de "atuar" e de "falar" aberta para "sotaques", mas a partir de uma mesma "língua" compartilhada.

Os padrões rítmicos-melódicos (clichês) são como um depósito de frases articuláveis, uma "hiperpartitura". A linguagem/sistema de referência se realiza a cada performance. A linguagem fala através daqueles que a realizam. E a linguagem está gravada no corpo, o constrói e é construída por ele.

Num modelo deste tipo existe um sistema ou uma sistematização que delineia um território fechado e limitado dentro do qual se dão as intervenções dos músicos. Há intervenções possíveis e outras impossíveis. Nesse sentido, ele é um campo de possibilidades e não de virtualidades, pois estas explodiriam o campo, seus modelos, julgamentos e leis (COSTA, 2016, p.183).

Por outro lado, o conceito de território também está presente nos estudos sobre gêneros musicais populares, como a polca paraguaia e a guarânia. Para o pesquisador Evandro Higa (2013) o "território" pode referir-se tanto a "um espaço físico e geográfico concreto até um espaço simbólico e abstrato" (HIGA, 2013, p.41).

É nesse sentido de território físico e espaço imaginário que o autor entende a continuidade/descontinuidade geográfica entre o Brasil e o Paraguay, em especial no que se refere às questões de ordem sociais, econômicas e tecnológicas na primeira metade do século $X X$, que intensificaram os fluxos migratórios e tiveram um papel importante na reterritorialização da música paraguaia no Brasil.

Quando nos referimos a processos de territorialização, desterritorialização e reterritorialização, nos reportamos a essa faceta

${ }^{15}$ No original: Non-idiomatic improvisation has other concerns and is most usually found in so-called "free" improvisation and, while it can be highly stylised, is not usually tied to representing an idiomatic identity (BAILEY, 1993, p.xi). 
imaterial do território-rede, que possibilita a constituição de circuitos por onde se constituem sentidos de identidade cultural que os agentes (produtores, mediadores e consumidores) vão construindo na diacronia do tempo e na sincronia dos espaços simbólicos sobrepostos" (HIGA, 2013, p.42).

No que se refere ao âmbito musical, o pesquisador Evandro Higa (2013, p.198) relaciona os idiomas ou gêneros com conjuntos de "eventos musicais - reais e possíveis", pois embora seus contornos sejam constantemente redimensionados na atividade musical cotidiana, seus desenvolvimentos estão vinculados a conjuntos de normas socialmente aceitas. Nesse sentido, o pesquisador Evandro Higa indica que:

os processos que determinam a categorização em gêneros são de natureza semiótica (...), definidos mediante uma rede de códigos que, em muitos casos históricos, já eram amplamente reconhecidos antes mesmo que a invenção de seu nome os consolidasse (HIGA, 2013, p.198).

Nesse sentido, os territórios, os idiomas ou os gêneros musicais sofrem a constante interferência entre a permanência de códigos que os definem e novas possibilidades que emergem da prática cotidiana. Aproximando as perspectivas dos professores, o idiomatismo dos territórios está atrelado às repetições periódicas dos componentes que estão dentro do conjunto de eventos musicais reais e possíveis socialmente aceitos por um determinado tempo histórico. A improvisação idiomática trabalharia por dentro desses preceitos, enquanto a improvisação não idiomática se desvincularia de qualquer compromisso de consenso, o que muitas vezes é entendido como uma postura de negação dos idiomas musicais.

Para o pesquisador Manuel Falleiros (2018), as estratégias de negação de Derek Bailey partem da sua procura por formas de desvinculação com o jazz estadunidense, e encontram sua base no uso radical dos conceitos de improvisação e liberdade:

Ou seja, a improvisação como um fazer sem absoluta preparação e livre de influências automatizadoras da formação e da experiência. Neste empenho, fica evidente a estratégia de sabotagem de um sistema reconhecido como estruturante, fornecendo ao termo liberdade sua significação condizente (FALLEIROS, 2018, p.189 - grifo no original).

As colocações de Bailey (1993) foram uma referência importante nos primeiros anos de encontros da Orquestra Errante. Lembro que naquela época enfatizamos exercícios que nos distanciassem de algum tipo de "idiomatismo". Por exemplo: "tocar só ruídos, sem 
nenhuma nota", "escolher uma região do instrumento para explorar", "evitar sensações rítmicas" eram algumas das abordagens. Assim, sob o pressuposto da exploração dos sons "libertos" de qualquer proximidade com os territórios idiomáticos, muitas vezes realizamos propostas trabalhando com parâmetros e estrições específicos. Algo muito parecido com o método que o pesquisador David Borgo chama de handicapping (limites/deficiências):

Handicapping refere-se a restrições auto impostas destinadas a limitar materiais e técnicas disponíveis para o improvisador. Elas podem ser restrições conceituais ou mesmo físicas impostas sobre o performer. As conceituais poderiam envolver tocar apenas uma nota ou dentro de um intervalo específico ou apontar para um modo uniforme de improvisação (...) Deficiências físicas podem incluir o uso de apenas uma parte específica do instrumento ou apenas uma mão (BORGO, 2002, p.174).

A perspectiva "não-idiomática" foi uma chave de leitura que nos permitiu acessar processos de criação desvinculados de territórios ou gêneros musicais. Foi um caminho necessário para encontrar as estratégias de superação dos idiomas musicais nos quais fomos formados. Uma postura de superação dos idiomas, nas palavras do Prof. Costa:

O músico deve se colocar em um processo constante de desterritorialização (...) Para isso, a partir de seu rosto (seus ritornelos e territórios, suas técnicas, seus sistemas e estilos) deve procurar o nível molecular em que é possível uma prática interativa liberada das estratificações molares (idiomáticas, estilísticas). Só a partir dessa perspectiva é possível uma performance coletiva (pensada enquanto jogo ou conversa) entre músicos de diferentes formações (COSTA, 2016, p.71).

Os conceitos de "Molecular" e "Molar" que o Prof. Costa utiliza para observar os processos na Livre Improvisação são acionados a partir da filosofia de Deleuze e Guattari.

No ambiente da Livre Improvisação predomina o nível molecular, que atravessa os níveis molares. Estes seriam, para Deleuze e Guattari, manifestações da estratificação e se relacionariam com o meio exterior dos estratos. Já o molecular se relaciona com o meio interior. No molar há estratificações particulares do molecular e, consequentemente, haveria uma diferenciação de um todo identificável (estilos, idiomas, sistemas, gestos). Segundo Deleuze e Guattari, é necessário almejar o molecular para superar os idiomas e os sistemas. A conhecida ideia deleuziana de que arte não se trata de reproduzir ou de inventar formas, mas de captar as forças, é fundamental para entender esse conceito de 
molecularidade. As "forças" estão presentes no nível molecular (COSTA, 2016, p.70).

Dessa perspectiva pode-se pensar o conceito de "som" desvinculado dos contextos idiomáticos e em contraposição à nota (que se vincula os sistemas idiomáticos), como "uma linha de força (com sua história energética) [que] se tornaria o material original e potente para uma prática musical liberada de qualquer sistema preestabelecido" (COSTA, 2016, p.71). Nos primeiros anos da Orquestra Errante enfatizamos essa perspectiva e procuramos nos "libertar" de nossas referências de formação. No entanto, como indica também o Prof. Costa, é impossível nos livrarmos das nossas experiencias e biografias. Além disso, outras ideias de músicas também interferiram em nossas reflexões com a Orquestra Errante e o NuSom, nos incentivando a considerar de maneira mais ampla o potencial do som.

Nesse sentido, o Prof. Fernando lazzetta e a Profa. Lilian Campesato alertam sobre a abordagem que considera somente as questões empíricas e materiais do som em detrimento de questões de raça, gênero e hegemonia dentro da prática musical, "ofuscando assim uma série de relações cuja compreensão é primordial para se perceber as diferentes faces da produção experimental" (IAZZETTA, CAMPESATO, 2019, p.17). Por exemplo, é necessário levar em conta a perspectiva afro-americana nos modos de criação de música em tempo real que impactaram profundamente a música a partir da segunda metade do século XX, como aponta o pesquisador e trombonista George Lewis (apud lazzetta, Campesato, 2019), e que foram excluídos dos discursos oficiais da música experimental institucionalizada.

Para Lewis esse tipo de discurso está em acordo com o projeto das vanguardas do pós-guerra que buscaram em alguma medida diminuir a referência à memória e aos contextos históricos, focando num aqui $e$ agora deslocado de contextos específicos (IAZZETTA, CAMPESATO, 2019, p.37 - grifo no original).

Portanto torna-se problemática uma postura que desconsidere os contextos - os lugares de fala - de onde surgem os sons, pois cada músico/musicista que se coloca em jogo na Livre Improvisação, também coloca em jogo suas referências biográficas. Tratam-se de expressões individuais impregnadas das histórias que se cruzam entre si, a partir do livre relacionamento proporcionado por essa prática musical. Para George Lewis, por 
exemplo, essa é uma história impregnada de heranças de escravidão e opressão, por isso:

A destruição da família e da linhagem, a reescrita da história e da memória na imagem da branquitude, é um dos fatos com os quais todas as pessoas de cor devem viver. Não surpreende, portanto, que, do ponto de vista da um ex-escravo, uma insistência em ser livre de memória possa ser vista com alguma suspeita - como uma forma de negação ou de desinformação (LEWIS apud IAZZETTA, CAMPESATO, 2019, p.38).

Essa negação ou desinformação corre o risco de excluir da expressão artística algo precioso, a história colocada em movimento, fricção e fruição. Esse entendimento, nos grupos de estudos NuSom e Orquestra Errante, nos aponta a necessidade de estudar o som como elemento catalizador a partir do qual criam-se relações de ampliação com outras áreas de pesquisa, como indica o Prof. lazzeta, pensar "não apenas o som, mas o som em relação a algo: sua natureza acústica, sua potencialidade estética, suas marcas e resquícios históricos etc." (IAZZETTA, 2014, p.2).

Essas abordagens, junto com as diversas pesquisas realizadas por alunos/as participantes da Orquestra Errante, incentivaram nossa permeabilidade - como grupo entre os procedimentos da Livre Improvisação e referências a componentes idiomáticos-biográficos. Com o tempo, fomos ampliando nossas estratégias ${ }^{16}$ de escuta e interação. Também ampliamos as ferramentas de criação explorando roteiros, partituras gráficas e outros tipos de direcionamentos e diretrizes, especialmente na criação de performances com algum tipo de "arco" semi-definido"

De maneira geral, as novas estratégias que criamos, individual e coletivamente, passaram a não focar mais na negação dos idiomas, mas a privilegiar a potência dos

\footnotetext{
16 Por exemplo a tese "Palavras sem discurso: estratégias criativas na Livre Improvisação" (2012), de Manuel Falleiros, onde desenvolve um estudo sobre a palavra como agente potencializador nos processos de criação em Livre Improvisação. A dissertação "O nativo-experimental: música experimental e seus contatos com a cosmologia nativo-ancestral da América do Sul" (2015) de Jonathan Xavier Andrade; e minha dissertação "O clownprovisadorlivre: um estudo sobre interação e performance na Livre Improvisação Musical” (2016). Pesquisas que foram desenvolvidas em parceria com a Orquestra Errante.

${ }^{17}$ As performances criadas trabalham com algumas diretrizes ou pontos referenciais onde são acionadas referências musicais, culturais ou imagéticas sobre Paraguay. São semi-definidos na medida em que as proporções entre as partes, os tempos internos da performance, a concatenação entre os pontos etc., não estão definidos e dependem da interação entre os/as participantes.
} 
encontros sonoros (com suas energias acústicas e afetivas), jogos em que as referências se entrecruzam e dissipam, se misturam e se transformam, se desterritorializam e reterritorializam, num processo que se aproximam daquilo que o Prof. Costa chama de "gaguejar na própria língua" (COSTA, 2016), colocando "em variação todos os elementos linguísticos e não linguísticos, as variáveis de expressão e as variáveis de conteúdo" (COSTA, 2016, p.3). Nessa abordagem não se desconsideram os "rostos biográficos" (COSTA, 2016) nem os "habitus" (HIGA, 2013), mas eles são colocados em interferência. Em outras palavras, a Livre Improvisação que praticamos na Orquestra Errante atualmente não é contra os idiomas, não se submete a eles, mas transita entre eles e volta a escapar.

Os apontamentos do pesquisador Manuel Falleiros (2018) demonstram como o diálogo entre o idiomatismo e a Livre Improvisação - em contraponto a uma simples oposição se fez importante para dar contorno ao que viemos a designar como fazer musical em livre improvisação:

Fica patente que se impõe aceitar que em nosso tempo se estabeleceu uma diferença definitiva na produção e recepção deste fazer musical. A Improvisação Livre como observamos hoje, inclusa como disciplina de faculdades, temática de festivais, motivo para engajamento criativo de músicos, com comunidades internacionais de troca de informações, como parte da expressão às críticas sociais, com um enorme corpus referencial que circunscreve suas particularidades sonoras etc.; apresenta as mesmas características das músicas idiomáticas que se referenciam historicamente, estilisticamente e que são antes mais fortemente denominadas a partir do estilo que as representam do que pelo termo improvisação em si. A Improvisação Livre, por estas características particulares, já se incluiria sem grande alarde - ainda que exclusivamente segundo os próprios preceitos estabelecidos por Bailey - na esfera das músicas idiomáticas (FALLEIROS, 2018, p.191 - grifo no original).

Na Orquestra Errante nossas ideias sobre Livre Improvisação foram ampliadas, tanto pelas pesquisas e experiências realizadas, como pela busca por um convívio pacífico e produtivo entre diversas visões, desejos e biografias pessoais. As interferências entre as distintas abordagens que experimentamos ao longo desses anos de existência nos permitiram projetar possibilidades de pesquisa e criação tais como as desenvolvidas aqui, que procuram transitar entre territórios e diluir suas fronteiras por meio da improvisação. 


\subsection{REFERÊNCIAS E REFERENTES: DAS TÓPICAS PARAGUAIAS ÀS IMAGENS DE COMPOSIÇÃO}

Para o pesquisador Acácio Piedade (2011) a musicalidade não é a capacidade ou aptidão para a música, mas se refere a uma espécie de memória(s) musical-cultural desenvolvida e compartilhada por "comunidades estáveis no seio das quais possibilita a comunicabilidade na performance e na audição musical" (PIEDADE, 2011, p.104). O pesquisador explica:

\footnotetext{
Vamos entender aqui a comunidade no sentido de agrupamento social com valores compartilhados, como em Bauman (...), seja este grupo territorializado ou não. Qualquer grupo social é sujeito a permanentes transformações, daí que "estabilidade", aqui, significa uma duração historicamente observável de um agrupamento, à qual se atribui significância em termos metodológicos (PIEDADE, 2011, p.104-105).
}

Dois conjuntos de referências profundamente diversos e significativos podem coabitar e se interpenetrar mutuamente. É assim que percebo em minha experiência musical os processos de Livre Improvisação da Orquestra Errante e a música paraguaia. Por um lado, a Orquestra Errante é um grupo "estável" - com mais de dez anos - que desenvolve suas ideias de músicas e metodologias de pesquisa e criação. Por outro, minha formação como músico paraguaio, que envolve estudos em conservatórios, experiências individuais e grupais de estudo e de trabalho profissional, além de meu habitus paraguaio e relação afetiva com minha cultura. 
Mais do que uma língua musical, portanto, musicalidade é uma audiçãode-mundo que ativa um sistema musical-simbólico através de um processo de experimentação e aprendizado que, por sua vez, enraíza profundamente esta forma de ordenar o mundo audível no sujeito (PIEDADE, 2011, p.105).

O conjunto de "audições-de-mundo", de memórias afetivas, de histórias que encontram ressonância, espaço e voz na música popular tradicional, não configuram um sistema fechado e imutável, mas estão em constante trânsito e transformação. Embora existam centros polarizadores ${ }^{18}$ (que entendem tradição como "tradicionalismo", isto é, conservação de certos valores estéticos e rejeição da renovação dos acervos), os contornos dos territórios são permeáveis, pois, músicos e musicistas podem transitar entre territórios, "desenvolvendo uma outra musicalidade, o que significa o exercício de uma competência em uma pedagogia estética sonora particular" (PIEDADE, 2011, p.105). O pesquisador Evandro Higa acrescenta:

(...) a existência de uma margem de interferência dos agentes individuais nesse processo de constituição da musicalidade, considerando que os indivíduos também detêm certa capacidade estruturante a partir de estratégias próprias do cotidiano, configurando historicamente seu habitus musical (HIGA, 2013, p.198 - grifo no original).

Para entender melhor a questão da musicalidade, o pesquisador Acácio Piedade (2013) propõe o conceito de "tópicas musicais" para identificar e isolar elementos musicais, e a partir deles apontar para sua referencialidade a algum idioma musical. Nesse sentido, a teoria das tópicas se apoia numa visão aristotélica que revela o processo retórico nas músicas, e parte do conceito de "topöi, elementos entendidos como lugares-comuns (em latim loci-communes)" (PIEDADE, 2013, p.7 - grifos no original). As tópicas seriam referências a territórios musicais e "pressupõe $(m)$ a visão da música como discurso, no qual se manifestam figuras da retórica musical" (PIEDADE, 2013, p.7).

As tópicas portam significados que são reconhecidos na sua época, se ligando também ao mundo literário, calcados em fortes aspectos

\footnotetext{
${ }^{18}$ Nesse sentido o Prof. Fernando lazzetta e a Profa. Lilian Campesato apontam: “A relação entre centro e periferia é sempre contingencial e autorreferencial. Centro e periferia não são posições absolutas numa cartografia cultural, mas regiões relativas e interdependentes. É o centro que expele certas práticas para os contornos periféricos, assim como são esses contornos que delimitam uma certa porção da cultura que se estabelece como centro" (IAZZETTA, CAMPESATO, 2019, p.16).
} 
socioculturais. Elas derivam de gestos convencionais e de gêneros familiares da comunidade que se situa na base da ação afetiva das tópicas, cobrindo a expressão de um mundo complexo de comunicação, fantasia e mito (PIEDADE, 2013, p.8).

Para o pesquisador Evandro Higa, a teoria das tópicas não só permite reconhecer referências culturais presentes em determinadas escalas, modos e ritmos, "como estabelecer imediatamente um senso comunitário que os une em uma teia de identificação e de solidariedade particular (HIGA, 2013, p.53).

A teoria das tópicas me ajudou a selecionar elementos musicais como referências para explorar em propostas de improvisação na Orquestra Errante.

Na música paraguaia se distinguem dois grandes gêneros: a "Polca paraguaia" e a "Guarânia". Pode-se dizer que existe ainda um terceiro: o "Rasguido doble", único gênero da música paraguaia em compasso binário e que deriva da "Habanera" de Cuba (SZARÁN, 1999). Na atualidade o Rasguido doble é um gênero pouco explorado em novas composições, por isso não dispõe do mesmo status que os dois primeiros.

A Polca Paraguaia e a Guarânia se caracterizam pela a sensação de sobreposição de três batidas contra duas, "construída com a melodia em compasso binário composto sobre uma base de acompanhamento ternário e com frequente utilização de sincopas na linha do canto" (HIGA, 2010, p.162). Esses são gêneros amplamente difundidos, ecoam tanto dentro do Paraguay como reverberam decisivamente na referência cultural musical do país mundo afora. O pesquisador Evandro Higa (2010) - a partir dos aportes do músico paraguaio Juan Max Boettner (1899-1958) -, descreve a estrutura rítmica desses dois gêneros como:

[A] alternância diacrônica de ritmos binários e ternários e, ao mesmo tempo, simultaneidade desses ritmos configurada no acompanhamento em 3 (com ocasionais e rápidas alternâncias binárias) sobre uma melodia em 2, desenvolvendo, portanto, uma polirritmia simultânea (BOETTNER apud HIGA, 2010, p.163).

Essa configuração rítmica é bem perceptível nas gravações da histórica "Banda Koygua" de Alejandro Cubilla, uma das principais referências sonoras que apresentei para a Orquestra Errante durante sessões de escuta de música paraguaia. Alejandro Cubilla (1929-2016) foi saxofonista e fagotista com uma longa e consistente carreira como 
músico em diversas orquestras e bandas militares no país. Por volta de 1957 fundou o grupo "Alejandro Cubilla y su Banda Koygua", dando sequência à antiga tradição das bandas musicais formadas por instrumentos de sopro e percussão que acompanham as procissões religiosas e profanas em datas festivas do Paraguay. Apesar do sucesso do grupo, que participou de turnês internacionais, ganhou prêmios em festivais de música folclórica e se manteve atividade até o falecimento do seu fundador, o grupo original chegou a gravar apenas dois discos. O primeiro foi gravado em 1962 para o selo Marpar e o segundo em 1966 para o selo Cerro Corá.

A partir dessas referências selecionei três tópicas rítmicas em compassos 6/8.

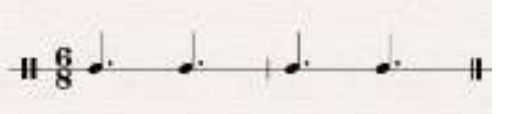

Figura 1. Semínimas pontuadas imagem (batida do chimbal)

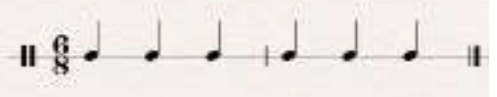

Figura 2. Semínimas (levada da tuba)

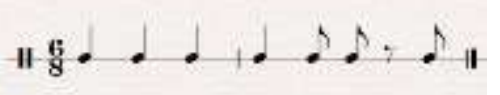

Figura 3. Semínimas e colcheias (variação rítmica típica do bumbo)

Depois da seleção de elementos musicais a partir dessa perspectiva de tópicas paraguaias, passei a explorá-las em jogos de improvisação com a Orquestra Errante.

No entanto, ao longo do trabalho com essas referências, observei que elas devem ser pensadas de outras maneiras na Livre Improvisação, pois em suas formas mais radicais a Livre Improvisação "não utiliza nenhum referencial explícito" como aponta o Prof. Rogério Costa (2016, p.194). Sua apresentação como estopim de um processo criativo no contexto da Livre Improvisação depende de uma perspectiva mais abrangente. É isso que o Prof. Costa indica ao destacar a relevância do referente para a improvisação, na medida em que pode ser entendido "como qualquer estratégia específica local que é 
estabelecida pelos músicos durante ou no começo de uma performance" (COSTA, 2016, p.193).

Nesse sentido, as referências paraguaias foram acionadas (interpretadas) nos começos ou durante as propostas, mas principalmente foram diluídas e transformadas pela criação coletiva. O referente "permite a coordenação do coletivo e, no contexto da improvisação livre, o que se torna coletivo é o passado e o presente da performance atual" (COSTA, 2016, p.196).

Por outro lado, para o pesquisador Acácio Piedade as tópicas dependem de sua "correta" disposição no plano composicional (remete à ideia de criação individual), pois "sua plenitude significativa, seu efeito de tópica se dá não tanto por sua estrutura interna mais pela posição de sua articulação no discurso musical" (PIEDADE, 2013, p.8). Nesse sentido são referências "mais fechadas" que remetem aos consensos musicais de comunidades de artistas e ouvintes.

Assim sendo, determinada figuração musical típica de um repertório partilhado e convencional, dependendo do ponto narrativo onde é apresentada e de como se concatena com figurações anteriores e posteriores no discurso musical, pode ou não funcionar como tópica (PIEDADE, 2013, p.9).

Ou seja, no contexto das tópicas existe o "certo" e "errado" e isso entra em conflito com os procedimentos da Livre Improvisação. No entanto, a partir da teoria das tópicas pude levantar elementos musicais que foram explorados, como mencionei, mas também depois revisitados durante os processos de criação das performances. Ela serviu de inspiração, mas teve seu uso revisitado e adaptado às demandas inerentes aos procedimentos criativos específicos da Livre Improvisação.

Nesse sentido, resgato aqui as aulas ${ }^{19}$ do Prof. Silvio Ferraz onde ele apresentou possibilidades de reescrita musical, tanto do ponto de vista conceitual quanto da prática criativa. A partir das suas colocações, estudamos a "conversão de imagens na prática composicional, não como mera transposição isomórfica (como proposta das leituras

\footnotetext{
${ }^{19}$ Disciplina CMU 6004-1/1 - A Noção de Imagem de Composição - Prof. Dr. Silvio Ferraz.
} 
estruturalistas dos anos 1960), mas como campo complexo de invenção artística" (FERRAZ, ementa da disciplina). Essa ideia de "imagens de composição" apresentada pelo Prof. Ferraz foi outra chave de leitura muito importante nos processos de criação das performances realizadas durante esta pesquisa. Aliás, ela está próxima de algumas ideias composicionais que viemos trabalhando com a Orquestra Errante, como nossas "comprovisações".

\subsection{COMPROVISAÇÃO: UM MODO DE CRIAÇÃO ERRANTE}

$\mathrm{Na}$ Orquestra Errante começamos a estudar a perspectiva da comprovisação em 2015 mais ou menos, numa abordagem que procurava entender o quadro conceitual para as práticas "que ficam a meio caminho entre as propostas de improvisação livre e as práticas composicionais que visam a mais completa determinação dos eventos sonoros" (ALIEL et. al., 2015). Aplicada à nossa prática com a orquestra, fomos entendendo-a como um modo de aproximar processos de composição e de improvisação, abordagens criativas antes consideradas distantes.

Apesar de a comprovisação parecer ser um conceito novo na literatura recente, ela pode ser vinculada à prática musical de início do século $\mathrm{XX}$, desdobrando-se de conceitos como a estética da indeterminação e da aleatoriedade, e surge da procura por processos composicionais através "de elementos estocásticos que aproximam-se da improvisação" (FARACO; FALLEIROS, 2019, p.1). Nesse sentido, para os pesquisadores Manuel Falleiros e Arthur Faraco (2019), a comprovisação pode ser vista como um movimento estético que deriva das práticas radicais de improvisação da década de 1960. Nesse sentido ela "possui interligações diretas com tais estéticas supracitadas porém com aspectos tecnológicos vinculados" (FARACO; FALLEIROS, 2019, p.2). Para os pesquisadores:

A comprovisação se destaca dos movimentos estéticos que perpassam - século XX devido ao uso de processos improvisatórios e composicionais com o uso devido de sistemas interativos tecnológicos 
ou tecnologias que auxiliam os processos (FARACO; FALLEIROS, 2019, p.2).

Foi sob esse viés que criamos junto com a Orquestra Errante e a KairosPania Cia. Cênico Sonora a performance "Suíte [en]quadrada20" -, uma performance desenvolvida no diálogo e tensão entre três linguagens artísticas: Jogo cênico, Livre Improvisação e Live electronics ${ }^{21}$. O processo criativo foi inspirado na peça televisiva “Quad” (1980), do dramaturgo e diretor irlandês Samuel Beckett (1903-1989). A interação que desenvolvemos entre jogo cênico e música na nossa "Suíte" ocorre por meio de um jogo randômico dos focos de luz em cena, que acionam os/as músicos/musicistas a partir do modo como os "escondem" ou "revelam" em cada um dos dez "movimentos" que compõem a performance. Assim, mediante o sorteio de fichas são configuradas as formações instrumentais (duos, trios, quartetos) que serão acionadas em cada um dos dez movimentos que acompanham os gestos dos/as performers de dança em cena. Apenas o técnico de luz conhece o resultado do sorteio - os músicos/musicistas não sabem de antemão e passam toda a performance aguardando se e quando serão iluminados para tocarem, se farão uma improvisação solo ou com colegas. O operador de Live electronics capta os movimentos dos/as bailarinos/as ${ }^{22}$ em cena por meio de uma webcam e os projeta em uma tela, no fundo do palco, e também soma ao material musical uma produção sonora criada automaticamente a partir dos movimentos captados pela câmera.

Cada linguagem artística que compõe a performance conta com certas diretrizes que propõem direcionalidades para o jogo. Nesse sentido, a "Suíte [en]quadrada" foi

\footnotetext{
20 Teaser da apresentação no Centro Cultural São Paulo, durante o Sonologia 2016 - Out of phase International Conference on Sound Studies, no youtube em:
}

\section{https://www.youtube.com/watch?v=ZJbud73u2GM}

Direção: Yonara Dantes e Migue Antar; Performers: Carmen Estevez, Kelly Caldas, Lara Kadocsa e Victor Pessoa; Músicos/musicistas: Antonio Goulart, Mariana Marinelli, Natalia Francischini, Mariana Carvalho, Pedro Sollero, Fabio Manzione e Migue Antar; Live electronics: Luzilei Aliel; Iluminação: Alexandre Passos; Registros audiovisual: Augusto Costa.

${ }^{21}$ Termo utilizado para nomear processamentos de sons e vídeo em tempo real por computadores.

${ }^{22}$ Os artistas que participaram da parte cênica da performance tinham formações em dança e/ou em teatro. Optei por denominá-los bailarinos/as devido ao acento dado à movimentação corporal desses artistas na performance. 
desenvolvida na esteira da criação coletiva e colaborativa (TENENBLAT, 2015). Coletiva na medida em que trabalha com direcionalidades, em vez de uma direção claramente definida, possibilitando vários caminhos para a performance que serão escolhidos e percorridos no devir do trabalho. E colaborativa na medida em que cada núcleo de criação contribuiu nas suas especificidades processuais e o resultado criativo obtido é decorrente do encontro e interferências entre essas linguagens, colocadas em contato.

Embora essa performance não tenha relação direta com a presente pesquisa, ela foi uma experiência muito importante para a Orquestra Errante pois nos abriu uma janela de oportunidades para pensar relações entre aspectos composicionais e jogos de improvisação, como a ideia de criação de performances que trabalhassem "diretrizes" e "contingências".

Entendemos que as diretrizes podem ser referências de qualquer tipo, como por exemplo: a indicação de aleatoriedade nas formações instrumentais que irão tocar determinado trecho, como na performance "Suíte [en]quadrada"; ou a definição de "pontos de passagens" ou de "chegadas", como na performance "TransPosições"23", também criação da Orquestra Errante junto com a KairosPania Cia. Cênico Sonora; ou ainda outros combinados que passam a direcionar as ações e decisões dos/as performers e músicos/musicistas envolvidos em cada performance. Já nas performances produzidas como desdobramento da presente pesquisa, a definição das diretrizes acionadas nas performances que criamos junto com a Orquestra Errante e a KairosPania Cia. Cênico Sonora, esteve submetida às trocas e conversas com os grupos sobre as referências paraguaias que propus que trabalhássemos. Essas performances são "Des a grad a vel", "A Síria não é aqui" e "Delfina”, apresentadas devidamente na segunda parte do presente trabalho.

\footnotetext{
${ }^{23}$ Teaser da apresentação no Festival Bigorna 2016 (praça Jose Molina, São Paulo), no youtube em: https://www.youtube.com/watch?v=Hd9WGankvXE

Direção: Yonara Dantas e Migue Antar; Performers: Carmen Estevez, Kelly Caldas, Yonara Dantas e Victor Pessoa; Músicos/musicistas: Rogério Costa, Ariane Stolfi, Inés Terra, Mariana Marinelli, Natalia Francischini, Mariana Carvalho, Fabio Martinelli, Hildelberto Peretti, Denis Abranches, Max Schenkman, Felipe Fraga, Pedro Sollero, Fabio Manzione, Migue Antar; Registro audiovisual: Luzilei Aliel.
} 
Observamos que por meio da sugestão de diretrizes, a comprovisação resultante induz a formação de estados provisórios (interferências construtivas) que se transformam e se diluem (interferências destrutivas) segundo as interações entre todos/as os/as envolvidos/as na performance. Isso envolve dois pontos importantes: o primeiro é a liberdade de manipulação das referências pensadas enquanto diretrizes. Ou seja, no caso de elementos musicais representados em partituras, o que está em jogo não é a sua "correta" leitura e interpretação, mas uma outra potência que deriva da sua exploração e que não está limitada pela representação gráfica.

O segundo se refere ao gerenciamento das partes e do todo. Ao estarem abertas para contingências - que se vinculam à interação entre os/as participantes -, o "arco de desenvolvimento", no sentido formal da performance, não se submete a uma estrutura fixa com suas partes e seções rigorosamente planejadas e delimitadas. As diretrizes sugerem algumas referências para serem acionadas, mas os tempos dessas ações, suas proporções, as conexões e transformações, estão atreladas à interação dos/as participantes. Em diálogo com essa perspectiva de criação, nas palavras do Prof. Rogério Costa, a comprovisação enfatiza a criação coletiva e colaborativa através da junção de "um planejamento composicional macroscópico (formal) anterior, mas os detalhes (nível microscópico: dinâmicas, durações, frequências, sonoridades etc.) são resolvidos (...) em tempo real durante a performance" (COSTA, 2017, p.10). O resultante final é obtido pela somatória das contribuições dos/as participantes em cada performance que varia a cada execução.

É nesse sentido também que os pesquisadores Manuel Falleiros e Arthur Faraco (2019), relacionam a comprovisação com uma nova leitura para o conceito de "obra aberta" de Humberto Eco, vinculada "não só ao entendimento de práticas musicais por elas mesmas, ou seja, uma discussão teórica que se vale apenas de ideias abstratas musicais, mas que teria como base os vínculos sociais, políticos e econômicos que definem a estética" (FARACO, FALLEIROS, 2019, p.2). Nessa perspectiva se amplia a compreensão da comprovisação como propostas nas quais estão intrínsecas as relações entre composição e improvisação, assistidas por meios tecnológicos, com o entendimento de que essas relações interferem nas questões formais da criação. Para o pesquisador Sandeep Bhagwati (apud FARACO, FALLEIROS, 2019): 
[A comprovisação se relaciona] a um espectro fictício que abrange todas as práticas musicais, tendo como parâmetro deste espectro as relações entre contingências (aberturas ou possibilidades de interpretação aberta nas obras) e elementos reproduzíveis, independentes de contexto (elementos notados e passíveis de reprodução). Logo, os extremos deste espectro seriam a Improvisação Livre (praticamente sem elementos reproduzíveis) e a composição fixa, a qual não é aberta a contingências (BHAGWATI apud FARACO, FALLEIROS, 2019, p.3-4).

Assim também é sob esse viés que temos pensado a comprovisação na Orquestra Errante. Nesse sentido, na presente pesquisa, tanto as propostas de improvisação explorando "tópicas paraguaias" - ou melhor: referentes paraguaios -, como as performances criadas a partir das possibilidades descobertas durante as explorações, podem ser pensadas como comprovisações. Em cada proposta foram desenvolvidas abordagens diferentes para representar ou indicar as diretrizes (as referências), e são elas que descrevo a seguir.

\subsubsection{REPRESENTAÇÕES GEOMÉTRICAS E FLUXOGRAMAS}

O pesquisador Godfried Toussaint apresenta no livro The Geometry of Musical Rhythm (2013), modos de representar estruturas rítmicas e fraseológicas por meio de gráficos circulares, semelhantes ao desenho de um relógio. Para o pesquisador as representações circulares facilitam a descrição de "muitas características estruturais dos ritmos que são mais difíceis de perceber com a notação ocidental da música" (TOUSSAINT, 2013, p.33 - tradução minha ${ }^{24}$ ).

Concordando com Toussaint a respeito da necessidade de se estudar formas de notação diversas da tradicional notação ocidental da música, tomei como base essa proposta de representação como primeira abordagem para explorar os três referentes rítmicos da polca paraguaia que selecionei nesta etapa (vide 2.1). Nesse sentido, para representar

\footnotetext{
${ }^{24}$ No original: many structural features of the rhythm that are more difficult to perceive with standard Western music notation (TOUSSAINT, 2013, p.33).
} 
geometricamente em círculos os ritmos paraguaios selecionados realizei os mesmos procedimentos descritos pelo pesquisador Toussaint nos ritmos que ele aborda.

Primeiramente atentei para o tamanho dos referentes selecionados, no seu sentido cíclico: os três referentes duram dois compassos de 6/8. O que significa que o ciclo de cada ritmo contém 12 batidas de colcheias, ou seja, 12 pulsações por ciclo.

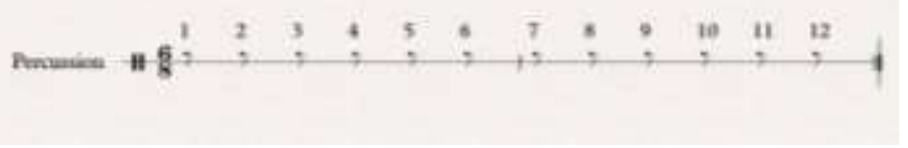

Figura 4. Pulsações por ciclo

Para representar geometricamente em círculos busquei dividir a figura do "relógio" segundo o número de pulsações por ciclo. No caso das referências paraguaias, a divisão dos círculos coincide com a figura típica de um relógio (12 partes), mas em outros casos, como por exemplo, para um padrão rítmico com duração de dois compassos de 4/4 o "relógio" será divido em 8 partes.

A partir da divisão do "relógio" é possível localizar sobre quais pulsações caem as batidas de um determinado ritmo cíclico, sendo que a leitura dos ciclos ocorre no sentido "horário".

A partir desses procedimentos cheguei nas seguintes grafias:
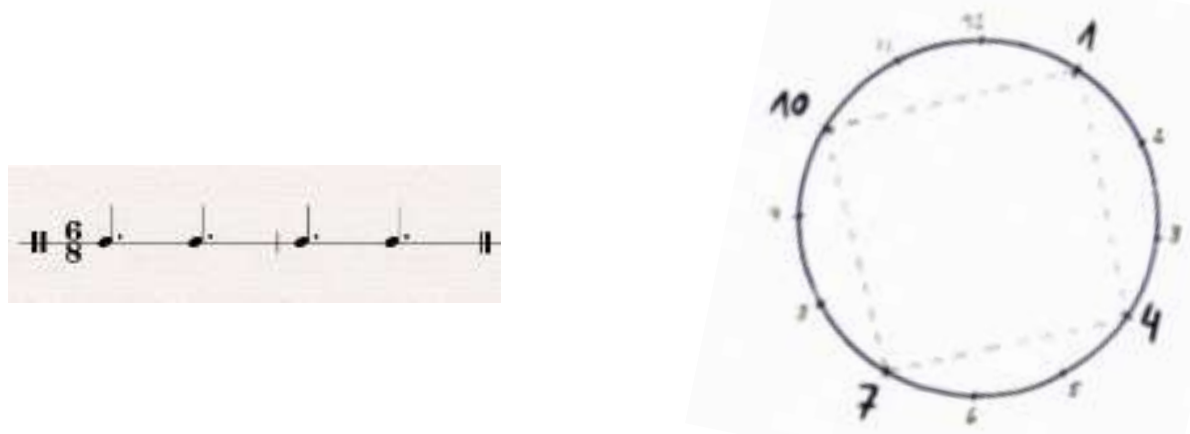

Figura 5. Semínimas pontuadas 

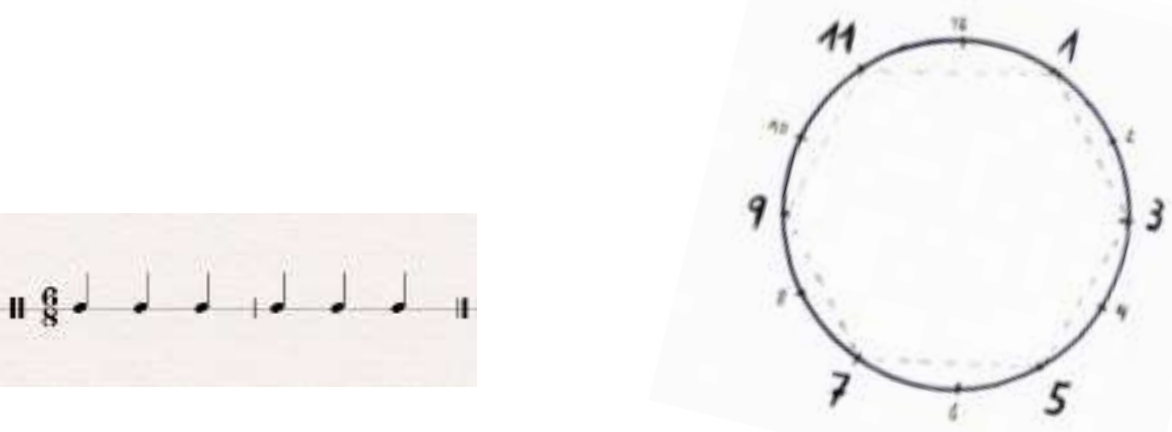

Figura 6. Semínimas
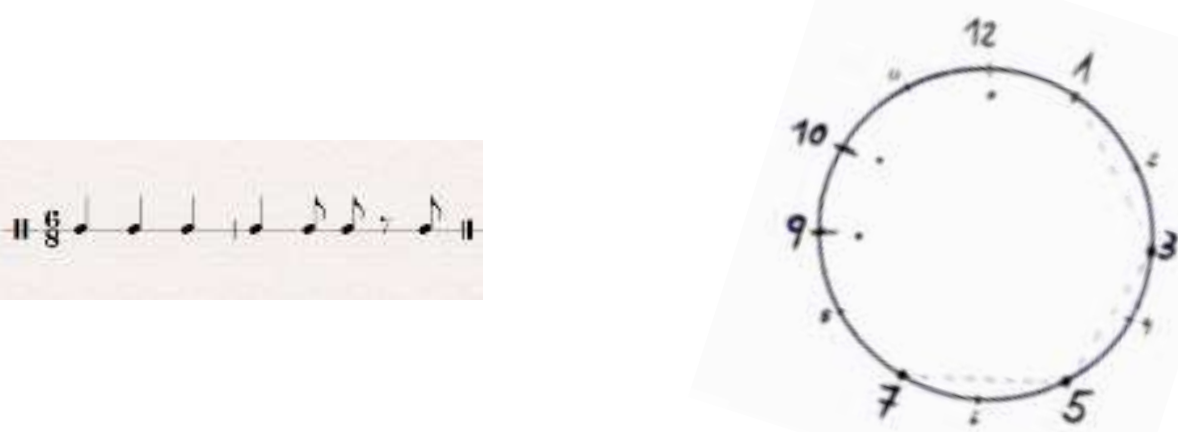

Figura 7. Semínimas e colcheias

Me pareceu interessante o contato com a música paraguaia que me foi proporcionado pela representação geométrica dos ritmos, pois aqui se enfatiza o caráter cíclico das "levadas" ou "grooves", o que permite uma outra apreciação (ou visualização) das sutilezas que envolve. Nesse sentido, nos encontros da Orquestra Errante (realizados no segundo semestre de 2017) em que trabalhamos com essas grafias, realizamos exercícios parecidos àqueles de aulas de percepção, batendo a pulsação com os pés e as figuras rítmicas com as palmas das mãos. Depois disso passamos a explorar as figuras com os instrumentos, em pequenas formações (duos, trios), alternando as três referências entre os grupos. Como já comentado, na dinâmica de encontros da Orquestra Errante prezamos pela reflexão e problematização das diversas propostas apresentadas, o que nos levou no caso dessa proposta a explorar essas grafias algumas 
vezes e a partir dessas experiências avaliamos coletivamente seus limites e potencialidades.

De maneira geral, músicos/musicistas da Orquestra Errante relataram dificuldades para improvisar "livremente 25 " a partir das representações geométricas. Apesar de oferecerem uma alternativa de grafia, enfatizando a questão cíclica do ritmo, o estranhamento que deriva dessa forma não habitual de representação foi observado como um "freio de mão" que não permitiu a fluência da improvisação. Observo ali uma dupla dificuldade: não se trata somente da proposição de uma outra forma de grafia para os materiais musicais, mas da necessidade de apropriação e contaminação desses materiais pelos/as músicos/musicistas. Para enfrentar essa questão, voltei a propor leituras didáticas das referências aliadas a sessões de escuta de músicas paraguaias, como as gravações da Banda Koygua de Alejandro Cubilla.

Apesar das dificuldades encontradas, algumas improvisações foram bastante proveitosas (segundo os comentários dos/as participantes), pois se encontraram alguns caminhos de exploração das referências, como se percebe na gravação ${ }^{26}$ do trio formado por Caio Righi na flauta transversal, Ronalde Monezzi no saxofone tenor e Fábio Manzione na percussão.

Durante os encontros da Orquestra Errante no segundo semestre de 2017 continuamos explorando outras possibilidades de jogos a partir de representações geométricas. Por exemplo, realizamos sessões mais longas de improvisação com pequenas formações instrumentais tocando simultaneamente, porém cada uma partindo de uma referência diferente. Ou em outras sessões onde propus alternar as "partituras" durante as improvisações, de modo a explorar o rodízio de referências no devir das improvisações.

Também propus improvisações combinando outras referências na esteira das representações geométricas. Numa nova "rodada" de jogos, acrescentei sugestões de

\footnotetext{
${ }^{25}$ Aqui no sentido em que utilizamos essa expressão na Orquestra Errante. Mesmo cientes de que estamos explorando alguma comprovisação, nosso lugar de criação sempre parte da Livre Improvisação.

26 O áudio se encontra disponível em: https://soundcloud.com/interferencias sonoras/circulos-iinterferencias-paraguayas-trio-orquestra-errante
} 
notas que poderiam ser tocadas na ordem que cada músico/musicista escolhesse. A escolha das notas era aleatória e não fazia referência a alguma música, escala ou tonalidade específica. Apresentei essas propostas para a Orquestra Errante em diversas folhas de papel, como se fossem "partituras", cada uma pensada para cada pessoa da orquestra e seu instrumento. Como exemplo coloco a seguir a "partitura" sugerida para a pianista Mariana Carvalho. A "partitura" contêm três folhas nas quais aparecem combinações rítmicas e sugestões de notas em círculos separados. Ou seja, dois "relógios" por folha, que equivalem as referências a serem acionadas.

Na folha 1 o círculo de cima sugere as notas do, sol, la, re (sem ordem de leitura), enquanto o círculo de baixo sugere a levada típica do bumbo na polca paraguaia: quatro semínimas, pausa de colcheia, duas colcheias, pausa de colcheia e recomeço do ciclo.

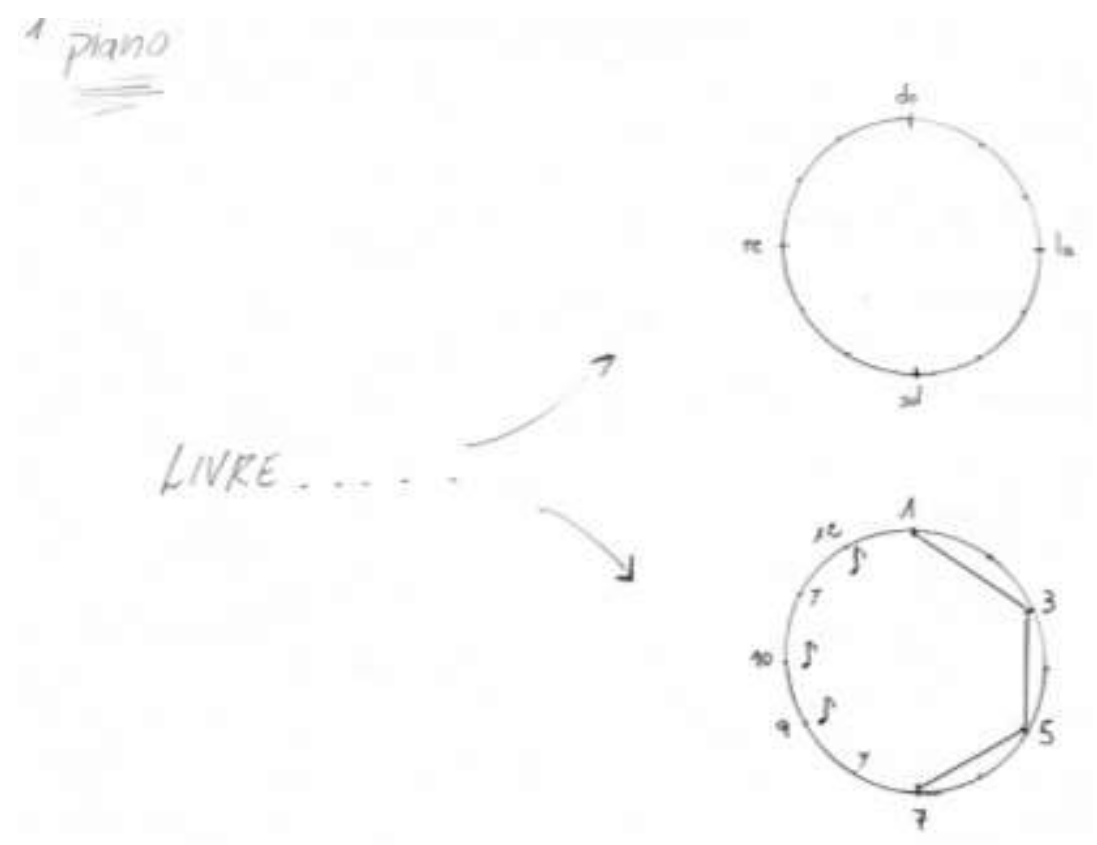

Figura 8. Padrão rítmico típico do bumbo na polca paraguaia e as notas do, sol, la, re.

Na folha 2, o círculo de baixo corresponde à representação geométrica de uma outra variante rítmica bastante utilizada na polca paraguaia: ciclos de silêncio de colcheia + duas colcheias. E no círculo de cima sugiro as notas sol, do, fa, la (sem ordem de leitura). 


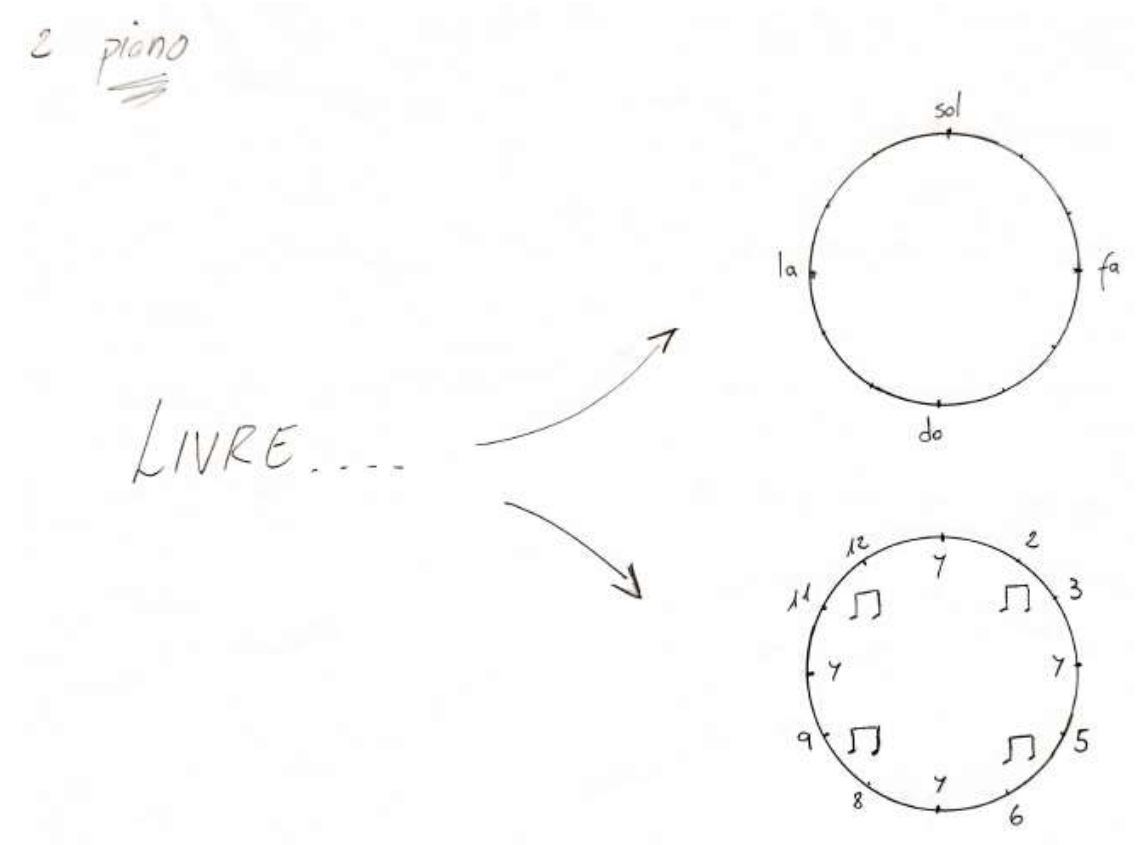

Figura 9. Padrão rítmico silêncio de colcheia + duas colcheias e as notas sol, do, fa, la.

$\mathrm{Na}$ terceira folha o círculo de baixo corresponde à representação geométrica da simultaneidade rítmica que ocorre na polca paraguaia e na guarânia: duas semínimas pontuadas contra três semínimas. E no círculo de cima sugiro as notas re, sol, mi, la (sem ordem de leitura).

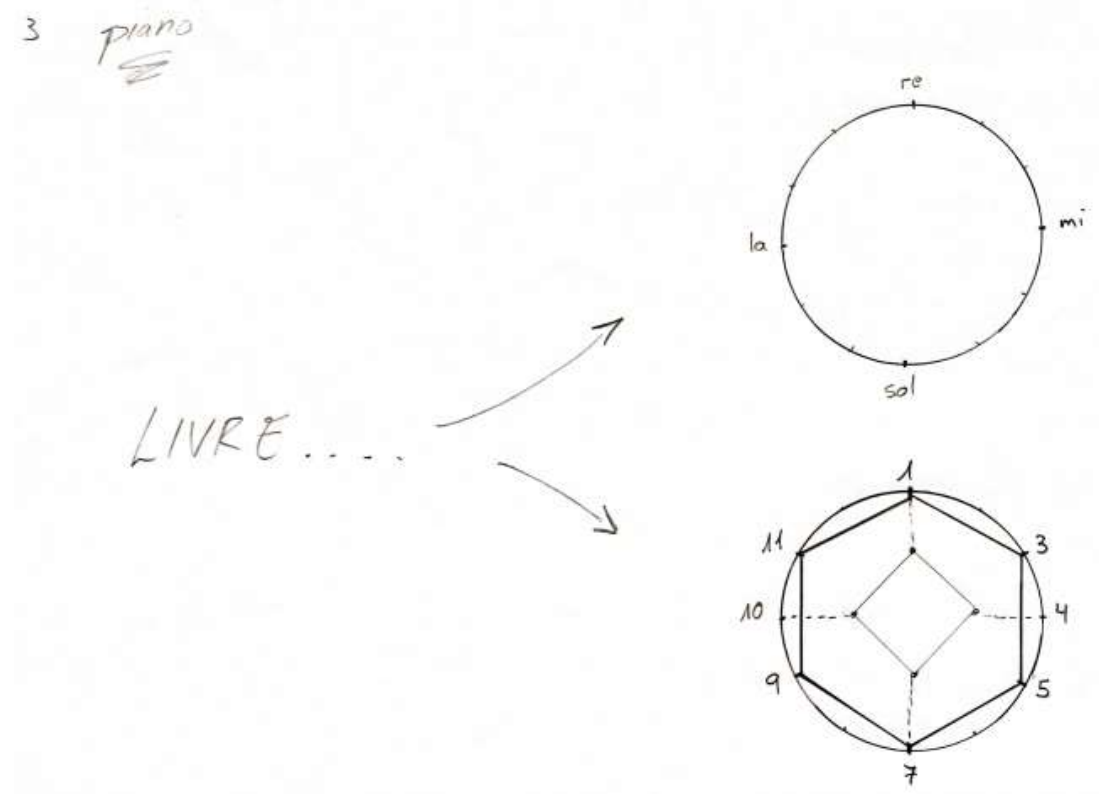

Figura 10. Padrão rítmico duas semínimas pontuadas contra três semínimas e as notas sol, re, mi, la. 
Assim também outros/as participantes receberam partituras com referências semelhantes, com algumas variações rítmicas e de sugestão de notas. O "arco" sugerido de forma coletiva (pois resultou das conversas do grupo sobre maneiras de conduzir a proposta) para o desenvolvimento da improvisação, foi o seguinte: a improvisação deveria iniciar de forma "livre" e só depois de um tempo (não definido previamente), segundo a vontade de cada músico/musicista, as referências seriam acionadas. Além disso cada participante poderia trocar de referência livremente (entre os círculos de uma mesma página ou também trocar de página).

Embora os comentários gerais dos/as participantes durante esses encontros tenham sido positivos no sentido de que se exercitaram a escuta e a interação, não foram em todas as experiências que percebemos a ressonância das referências nas improvisações, seja porque os elementos não foram acionados ou porque mesmo acionados não geraram interesse. Nesse sentido, como já mencionei, é normal que as pessoas problematizem, apontem limites, sugiram modificações e até novas abordagens para as propostas apresentadas. Foi assim que percebi que a utilização das representações geométricas nos ajudou como um primeiro passo para estudar alguns elementos musicais que fazem referência ao Paraguay. Porém, a mediação gráfica e distante das notações tradicionais de música, ampliou as dificuldades para apropriação e manipulação dos materiais sugeridos.

Ainda assim, essas experiências foram importantes para que eu pudesse explorar as interferências de referências durante as improvisações e, nesse sentido, observar como alguns elementos musicais ainda conservam um certo grau de pregnância, mesmo que desterritorializados, como no caso das variantes rítmicas da polca paraguaia: ciclos de silêncio de colcheia + duas colcheias, e duas semínimas pontuadas contra três semínimas. A pregnância, conceito apreendido da Teoria da Gestalt, diz respeito ao grau de facilidade com que uma figura pode ser captada pelo olho humano. Quanto maior a pregnância, maior é a facilidade de destaque da figura. No sentido prático, em um grupo de figuras, aquela que chama a atenção do olho mais rapidamente é aquela que tem maior pregnância. Aplicado à Livre Improvisação, os referentes que têm maior pregnância são aqueles que se destacam do fluxo sonoro e interferem nele, seja reforçando a construção de um bloco/evento, seja dispersando-o. 
Após essas experiências com as representações circulares, propus novas abordagens, dessa vez explorando a grafia tradicional em jogos de combinações livres. Também passei a trabalhar mais com sessões de escuta de músicas paraguaias com a Orquestra Errante.

\subsubsection{DA TRANSCRIÇÃO À COMPROVISAÇÃO: POLCAS "ACHUITA" E} "CIELITO CHOPI"

A partir das experiências com as representações geométricas, percebi a necessidade de maior contato da Orquestra Errante com o repertório paraguaio, por isso propus sessões de escuta onde ouvimos outras gravações de polcas pela Banda Koygua de Alejandro Cubilla. Além disso, o grupo tinha sugerido explorar referências utilizando a notação tradicional, assim, escrevi duas propostas que atendiam a essa expectativa a partir das polcas paraguaias "Achuita" (motivo popular) e "Cielito Chopi" (motivo popular).

Nesse sentido, também é importante mencionar a flexibilização que propus para a "leitura" das referências escritas. A utilização de notação tradicional foi uma proposta que partiu do grupo após as experiências com representações geométricas, e para a abordagem que proponho das referências paraguaias me interessa que elas sejam acionadas como sugestões e impulsos, e não que estejam condicionadas a alguma "correta" leitura no sentido tradicional. Ou seja, mantive aquilo que é uma marca da Orquestra Errante, uma total liberdade para modificar as referências sugeridas.

A polca "Achuita", de autor desconhecido, faz parte do repertório de música tradicional popular e, em especial, é uma polca muito executada junto às companhias de dança folclórica do Paraguay. Embora na bibliografia de música paraguaia a qual tive acesso eu não tenha encontrado dados a respeito desta obra em particular, existem gravações da polca "Achuita" por diversos grupos artísticos, na sua grande maioria, em versões instrumentais. 
Uma exceção é a gravação ${ }^{27}$ de 1927 pelo Duo Gimenez Pucheta (Herminio Gimenez ${ }^{28}$ e Justo Pucheta ${ }^{29}$ ), onde a polca conta com a letra apresentada no idioma guarani. Foi nesse mesmo ano de 1927 que Gimenez e Pucheta iniciaram o trabalho em duo e foram contratados pela "Casa de Música de Manuel Viladesau", em Buenos Aires, Argentina, onde gravaram dez discos de música paraguaia pelo "Sello Guaraní". Para o pesquisador Luis Szarán (1999), “este empreendimento contribuiu para preservar antigas criações do cancioneiro popular como: El Karaü, Caazapá, Jazy moroti, Korazö rasy entre outras" (SZARÁN, 1999, p.223 - grifos no original - tradução minha ${ }^{30}$ ), e é nesse contexto que se insere essa histórica gravação de "Achuita” pelo Duo Gimenez Pucheta. O resgate dessa música, feita naquela época, sem dúvida contribuiu para sua permanência no repertório paraguaio, o que faz da polca "Achuita" uma das músicas mais populares nas festas tradicionais do país.

Embora a versão do Duo Gimenez Pucheta para "Achuita" conte com a presença da letra e o arranjo da música apresente outros elementos que não estão presentes nas demais gravações - como quadratura e interlúdios instrumentais diferentes -, essa versão não costuma ser utilizada como referência da música no contexto das celebrações populares, pois na atualidade ela é uma polca instrumental. Atentando a isso, apresentei para a Orquestra Errante outras versões da música disponíveis no youtube, em especial as gravações "amadoras", feitas pelo público desses eventos, de maneira a mostrar também o contexto de celebração onde se insere esse repertório. Um exemplo é a

\footnotetext{
${ }^{27}$ A gravação (que foi utilizada para montar um vídeo de dança) se encontra disponível no youtube em: https://www.youtube.com/watch?fbclid=IwAR14xwVylg37eA-

v6qulgYXcHiDv16tkWgyyYo170ZBBTA1peSFxUoEDj88\&v=atECCZSuVtQ\&feature=youtu.be (último acesso janeiro 2021).

${ }^{28}$ Herminio Gimenez (1905-1991), foi um reconhecido músico, compositor e regente paraguaio. Durante a Guerra del Chaco (1932-1935) entre Bolivia e Paraguay, foi assignado Diretor da Banda Militar. Ao longo de sua carreira como regente esteve à frente de orquestras em Buenos Aires, Rio de Janeiro e Nova York. Foi exiliado político durante a ditadura de Alfredo Stroessner.

29 Justo Pucheta Ortega (1904-s/d), foi músico e junto com Herminio Gimenez realizou algumas das primeiras gravações de músicas paraguaias no fim da década de 1920. Anos depois se voltou para a carreira de direito, tornando-se magistrado e Presidente da Corte Suprema de Justicia no Paraguay.

${ }^{30}$ No original: este emprendimiento contribuyó a preservar antiguas creaciones del cancionero popular como: El karaü, Caazapá, Jazy moroti, Korazö rasy entre otras (ZSARÁN, 1999, p.223).
} 
gravação ${ }^{31}$ da apresentação do "Ballet Folklorico Juvenil del Instituto Municipal de Arte (IMA)", do Paraguay, com a coreografia da Profa. Maria Magdalena Duarte.

A partir dessas audições de versões instrumentais e "mais modernas", escrevi ${ }^{32}$ (no primeiro semestre de 2018) um pequeno arranjo de “Achuita" para a Orquestra Errante com as respectivas vozes para os instrumentos: saxofones soprano, alto e tenor, trombone baixo e piano. Cada uma das vozes foi apresentada em folhas separadas para cada instrumento. A parte do piano continha as cifras, servindo de guia para outros instrumentos como guitarras, violões, vozes e contrabaixo. Escolhi escrever somente para esses instrumentos de sopros e o piano porque apesar de esperar que todos/as os/as integrantes do grupo compareçam a todos os encontros, é normal que a cada semana uma parte do grupo seja composta por outras pessoas. Assim, garantindo a escrita dos sopros e do piano, entendia ser possível desenvolver a proposta na Orquestra Errante independente da formação instrumental de cada encontro.

Propus a realização de várias leituras da proposta, tanto na tentativa de proporcionar um "estudo" das referências, como também de possibilitar a execução de improvisações a partir delas. No entanto, as improvisações que surgiram nessa proposta se limitaram a leitura clássica "jazzística" da forma musical, com repetições das partes A e B nas mesmas proporções (pulsações e número de compassos) que as pautadas pela grafia tradicional em partitura. Dessas sessões destaco a gravação ${ }^{33}$ de julho de 2018 (vide nota de rodapé) da qual participaram: Rogério Costa, saxofone soprano, Caio Righi, saxofone alto; Rafael Clarin, saxofone tenor; Paola Pichersky, violão de sete cordas; Denis Abranches, luteria experimental; Fabio Manzione, bateria; e eu, no contrabaixo.

Esse momento de "estudo" das referências paraguaias num sentido mais didático e musical foi importante para afirmar e balizar algumas questões - como por exemplo a

\footnotetext{
${ }^{31}$ A gravação se encontra disponível no youtube em: https://www.youtube.com/watch?v=BbUfE-2lubE (último acesso janeiro 2021).

${ }^{32}$ A grade completa se encontra no Apêndice $A$ do presente trabalho.

33 O áudio da gravação se encontra disponível em:

https://soundcloud.com/interferencias sonoras/achuita-interferencias-paraguayas-orquestra-errante
} 
polirritmia paraguaia de 2 contra 3 - que podem ser difíceis e distantes de se incorporar na prática se o contato com a música se concentra apenas na explicação teórica e mesmo em alguns exercícios de percepção corporal.

Após algumas semanas e encontros de "mergulho" nas referências paraguaias, propus uma nova abordagem para o trabalho a partir de estruturas "comprovisatórias", mantendo a utilização da notação tradicional.

\subsubsection{EXPLORANDO PARTITURAS-CARTAZES: POLCAS "GALOPERA", "PÁJARO CAMPANA" E "CIELITO CHOPI".}

Para esta nova etapa de investigação, pensei propor jogos de improvisação a partir da livre combinação de referências paraguaias apresentadas em grandes folhas de cartolina, como uma espécie de "partituras-cartazes". Para a escrita das referências também optei pela grafia tradicional, ou seja, as coloquei no pentagrama. Esta nova série de jogos contou com duas versões. Na primeira, que tratarei agora, escolhi escrever os elementos musicais em grades, com alguns instrumentos (transpostos ou não) na mesma folha de cartolina. Assim, na grade, todos/as poderiam ver as diferentes referências para cada um/a. Desse modo, em cada partitura-cartaz inseri quatro pequenas grades ao redor de um círculo que sugere movimentos horário e anti-horários para a troca de referências, ou seja, das grades.

Nesta primeira versão das partituras-cartazes escolhi escrever para os seguintes instrumentos: saxofones soprano, alto e tenor, trombone baixo, piano e percussão. A Orquestra Errante conta com mais instrumentos (violino, viola, guitarras, violões, luteria experimental, vozes), mas escolhi não escrever para eles. Minha opção foi convidá-los para que interagissem livremente com as referências acionadas pelos instrumentos com grades a seguir.

Outra questão discutida foi a leitura das partituras-cartazes a partir da ideia do círculo, problematizada já nas primeiras experiências com essa proposta. O grupo achou melhor não se submeter às opções horário e anti-horário, permitindo uma leitura livre e 
alternada entre as referências, assim cada músico/musicista poderia escolher a referência que quisesse, no momento que julgasse mais adequado.

Nesta etapa, para a seleção das referências, escolhi duas músicas muito conhecidas tanto no Paraguay como no Brasil, interpretadas de inúmeras maneiras por diversos/as artistas de ambos os países: "Galopera", composta pelo flautista e violinista paraguaio Mauricio Cardozo Ocampo (1907-1982) e "Pájaro Campana" composta pelo harpista paraguaio Félix Pérez Cardozo (1908-1952).

Essas músicas fazem parte de um repertório amplamente tocado nas regiões fronteiriças, como indicam a pesquisadora Geni Rosa Duarte e o pesquisador Emilio Gonzales (2013) quando relatam as experiências de músicos/musicistas que estiveram em constate deslocamento pelas fronteiras entre Paraguay, Argentina e Brasil entre os anos 1960 e 1970. Esse trânsito de artistas de vários países pelas suas regiões de fronteira promove uma "complexa integração, fazendo isso através da música, da arte (...) [consegue] flexibilizar aquela rigidez do Estado-Nação e das linhas de fronteira preestabelecidas" (GONZALEZ, DUARTE, 2013, p.49). Dos comentários sobre o caso particular do músico paraguaio Casemiro Pinto Castro que viveu essa experiência de fronteira - nascido em 1944 e radicado desde 1960 em Foz do Iguaçu -, destaco:

(...) são poucas as músicas que ele é chamado a tocar que representem para os turistas aquilo que é paraguaio, ao que se segue, segundo ele, o que é argentino e o que é brasileiro, muitas vezes combinando música e dança. Dessa forma, para lembrar o Paraguay, Casemiro toca Pájaro Campana, Recuerdos de Ypacarai e Galopera, composições que ele identifica com antigas. Portanto, inscritas numa tradição, elas evocam o Estado-Nação a partir do seu passado, da sua história (GONZALEZ, DUARTE, 2013, p.50 - grifos no original).

"Galopera" e "Pájaro Campana" são músicas que representam o Paraguay. Contudo, as versões em português apresentam tamanha força no cancioneiro brasileiro que também constam no repertório de música folclórica brasileira. "Galopera" é amplamente conhecida devido a sua gravação pela dupla sertaneja Chitãozinho e Xororó. "Pájaro Campana" conta com diversas denominações - conhecida como "Araponga" na região de Campo Grande, Mato Grosso, foi titulada "A volta do Guaira Campana", no disco Raiz 
Pantaneira (1997) da violonista Dona Helena Meirelles ${ }^{34}$ (1924-2005); e ainda grafada como "A volta do Guyra Campana", no disco "Ao vivo", também da Dona Helena.

Tendo escolhido essas duas músicas para trabalhar nas próximas propostas, as apresentei para a Orquestra Errante em sessões de escuta. Dentre as versões ouvidas se destaca a versão de "Galopeira" gravada35 pela Banda Koygua de Alejandro Cubilla, escolhida pelo trabalho com instrumentos de sopros. Também ouvimos as versões das duas músicas gravadas por Dona Helena Meirelles. A partir delas transcrevi alguns motivos melódicos que utilizei como referências para compor as partituras-cartazes. Atentei para a manutenção da liberdade de modificar notas e ritmos, a permutação entre referências e o agenciamento grupal das "proporções", aspectos que caracterizam as comprovisações da Orquestra Errante.

Da polca "Galopera" selecionei a parte do refrão muito conhecida em que se sustenta a terceira sílaba da palavra "galopera". Em várias versões paraguaias, o tempo da sustentação dessa nota não dura mais que 4 compassos, como nos casos das gravações da Banda Koygua de Alejandro Cubilla (gravação da década de 1960), de Luis Alberto del Paraná com o Trio Los Paraguayos (gravação 36 de 1958), e a versão brasileira de Dona Helena Meirelles, que está no documentário37 de Dainara Toffoli, "Dona Helena”, de 2006. Aliás, no documentário, Dona Helena se refere a essa música como "Capelinha Branca". Na versão da dupla Chitãozinho e Xororó, o arranjo introduz a sustentação por 11 compassos, o que hoje aparece como clichê e paródia da música paraguaia.

\footnotetext{
${ }^{34}$ Dona Helena Meirelles (1924-2004) foi uma violeira e cantora brasileira, filha de paraguaios e brasileiros (MEIRELLES apud TOFFOLI, 2006) que se tornou referência da música de Campo Grande. Gravou seu primeiro disco em 1994, aos 70 anos de idade. Foi eleita pela revista americana Guitar Player como uma das 100 melhores instrumentistas do mundo.

${ }^{35}$ A gravação se encontra disponível em: https://soundcloud.com/interferencias sonoras/galoperabandita-koygua-de-alejandro-cubilla

${ }^{36}$ A versão de "Galopera" pelo Trio Los Paraguayos se encontra disponível no youtube em: https://www.youtube.com/watch?v=dTsAEQ0GPUk (acesso janeiro 2021).

${ }^{37}$ Disponível no youtube no link: https://www.youtube.com/watch?v=nTGOLwoOYa0 (acesso janeiro 2021).
} 
Da polca "Pájaro Campana" selecionei o motivo inicial, onde se alternam apenas duas notas num movimento que aos poucos vai acelerando, a partir da versão original gravada ${ }^{38} \mathrm{em} 1951$ pelo compositor, o harpista Felix Perez Cardozo, e lançada em um disco póstumo em 1960.

A partir dessas referências compus quatro pequenas grades, que depois coloquei em numa grande folha de cartolina formando a partitura-cartaz. No meio da folha de cartolina desenhei um círculo e marquei as posições "meio-dia", "três horas", "seis horas" e "nove horas" como se fosse num relógio (lembrando as propostas de representação geométricas) e as quatro pequenas grades ficaram posicionadas ao redor do círculo, cada uma numa "hora" do relógio. As referências que propus para cada grade foram:

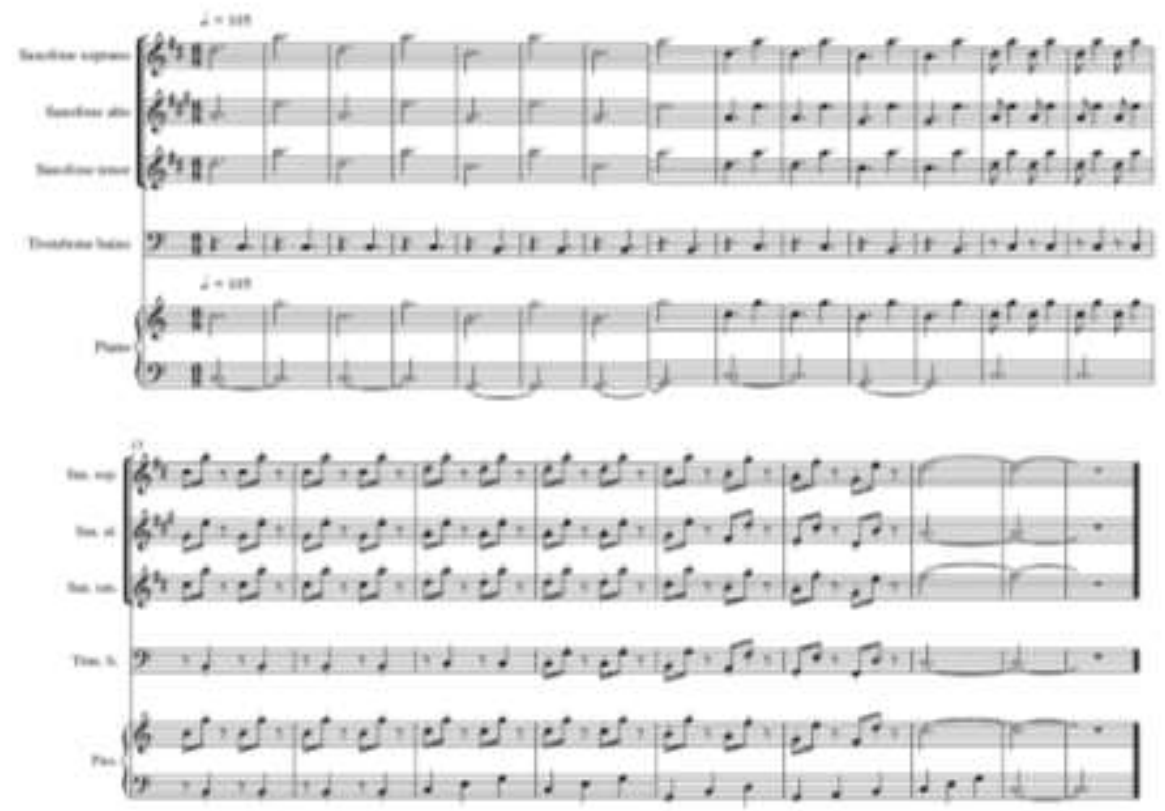

Figura 11. Material “meio-dia”, a partir da polca "Pájaro Campana”

${ }^{38}$ A gravação original de "Pájaro Campana" por Félix Perez Cardozo se encontra disponível no youtube em: https://www.youtube.com/watch?v=eP Y9Rogqbl (acesso janeiro 2021). 


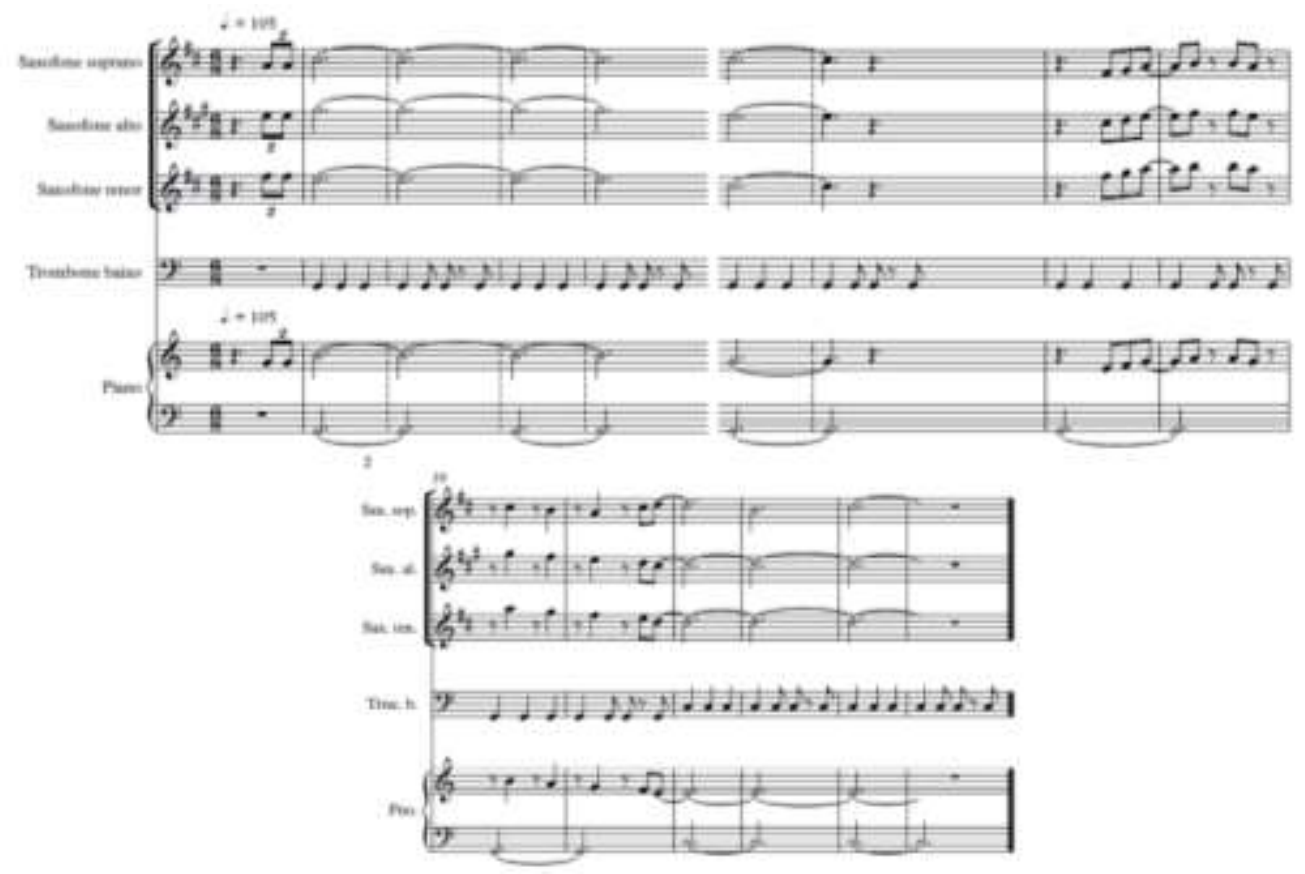

Figura 12. Material "três horas", a partir da polca "Galopera"

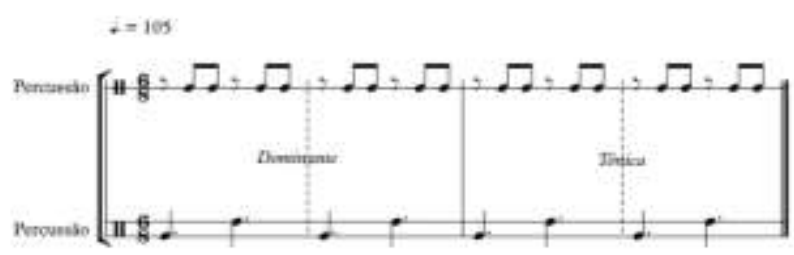

Figura 13. Material "seis horas" da partitura-cartaz 


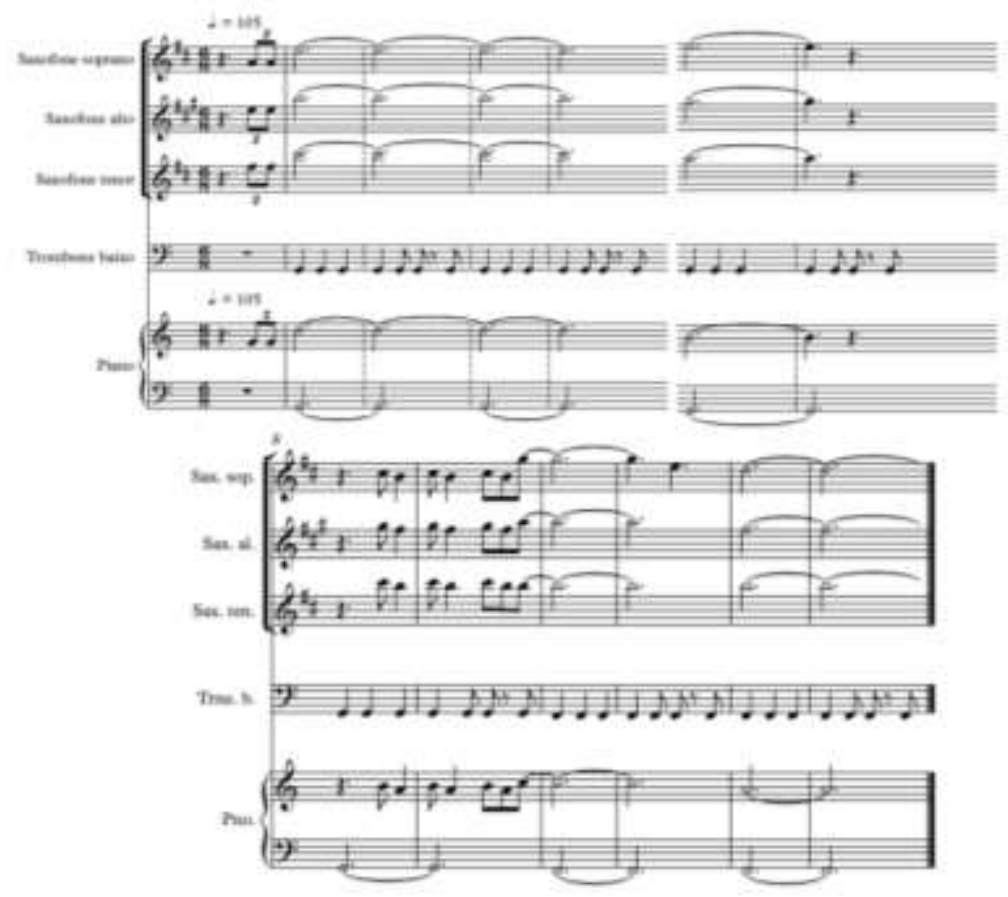

Figura 14. Material "nove horas", a partir da polca "Galopera" 
Como mencionei, esses materiais foram colocados ao redor de um círculo em uma grande folha de cartolina, ficando da seguinte maneira:

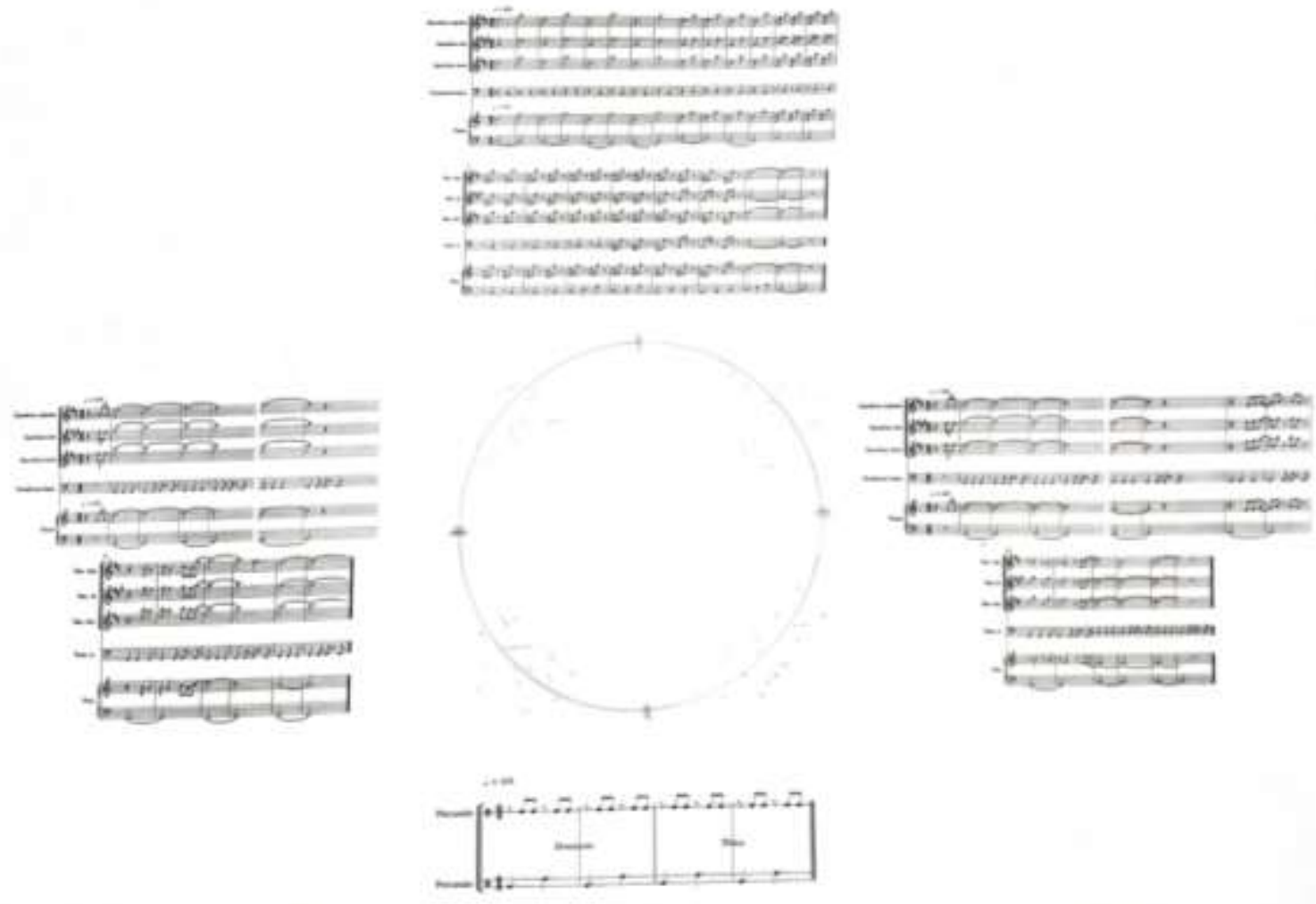

Figura 15. Partitura-cartaz com quatro materiais sugeridos
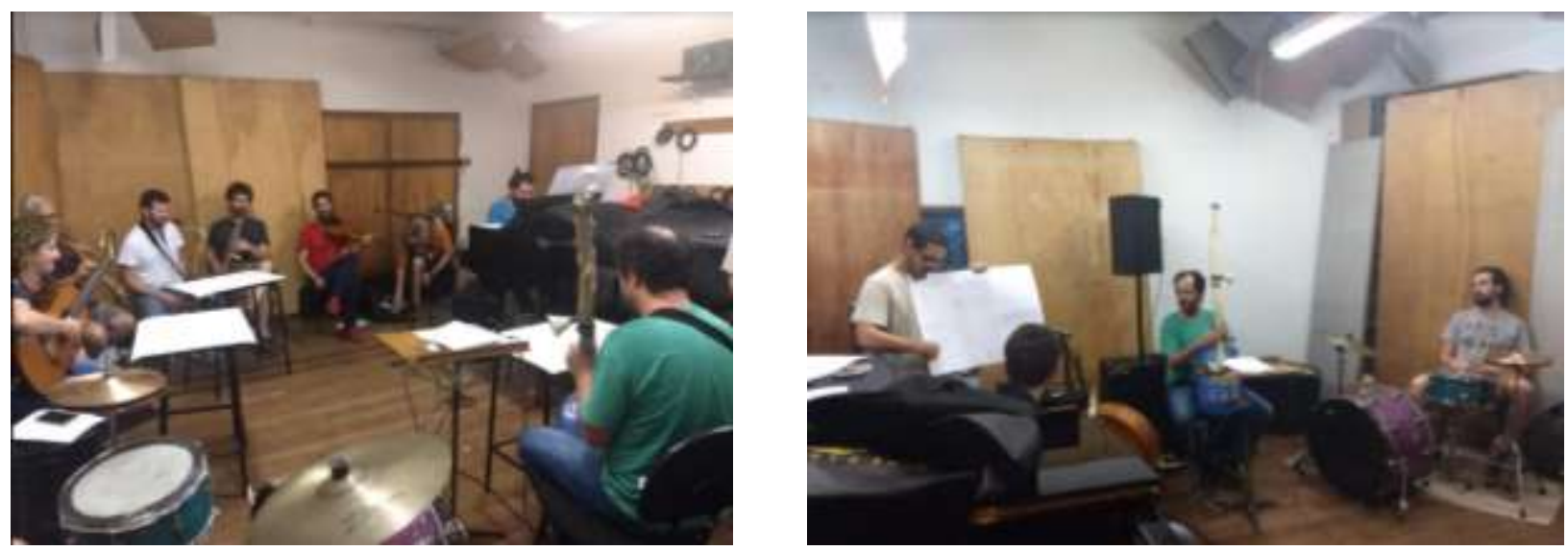

Figura 16. Encontros da Orquestra Errante em novembro de 2018. Registros de Yonara Dantas. 
Realizei várias cópias da partitura-cartaz, para que todos/as da Orquestra Errante pudessem realizar uma leitura confortável. Porém uma das primeiras dificuldades que os/as participantes relataram foi com relação às grades, já que o tamanho da fonte, ou seja, das notas colocadas nas pautas, não foi grande o suficientemente para ajudar na leitura. Outro ponto destacado nesta proposta foi que, como as referências estavam escritas "em grade", o acionar da maioria delas se executou de maneira quase sincronizada pelos naipes de instrumentos, como se percebe na gravação ${ }^{39}$ de uma dessas experiências no segundo semestre de 2018 (vide nota de rodapé). Participaram: Rogério Costa, saxofone soprano; Caio Righi, saxofone alto; Rafael Clarín, saxofone tenor; Marina Mapurunga, violino; Cesar Martini, viola; Paolo Picherzky, violão de sete cordas; Guilherme Beraldo, violão; Stênio Biazon, piano; Fábio Manzione, bateria; e eu, no contrabaixo.

Nessa improvisação decidimos que o início seria livre. Por volta do 2' o material "seis horas" (Pájaro Campana) é acionado pelos sopros o que se percebe com a utilização de silêncio de colcheia + duas colcheias, que rapidamente interferem e contaminam o fluxo do coletivo. Mais adiante, por volta do 4', se percebem os fragmentos correspondentes ao material "nove horas" (Galopera), desta vez interferindo na sustentação que essa "tópica" sugere. Um pouco depois se aciona o material "meio-dia" onde se percebe o fragmento inicial da polca "Pájaro Campana". Já a resposta para a frase da Galopera, no sentido da frase conclusiva referente ao refrão original, aparece ao final da improvisação, no 8'.

Nessa experiência observei que a memória compartilhada dessa música (muito conhecida no Brasil) parece ter facilitado a pregnância do material. As vozes que se surgem em resposta aos impulsos - as referências - afirmam essa potência da memória e da criação. Também observei que as referências acionadas no contexto da Livre Improvisação que praticamos na Orquestra Errante deixaram de funcionar como tópicas, pois os materiais (des)(re)territorializados foram livremente colocados no fluxo

\footnotetext{
${ }^{39}$ A gravação se encontra disponível em: https://soundcloud.com/interferencias sonoras/galopera-ypajaro-campana-interferencias-paraguayas-orquestra-errante
} 
sonoro durante seu devir. Neste ponto cabe lembrar a perspectiva do pesquisador Acácio Piedade (2013), para quem as tópicas só funcionam como tal devido a sua correta colocação dentro do discurso musical.

Após algumas semanas, voltei a propor uma nova partitura-cartaz para o Orquestra Errante. Para essa nova abordagem escolhi uma outra polca paraguaia e a partir dela escrevi materiais específicos para alguns instrumentos, ao invés de escrever em "grades". Elaborei as partituras-cartazes separadamente, uma para cada instrumento: saxofone soprano, saxofone alto, saxofone tenor, trombone baixo, piano, violino, percussão, contrabaixo e voz. Também aumentei o tamanho das fontes para facilitar a leitura.

A música de referência para esta nova iniciativa foi a polca "Cielito Chopi", que é também a música de uma dança paraguaia, oriunda do repertório tradicional e tida como motivo popular, sem autor/a definido/a. A pesquisadora Celia Ruiz De Domínguez (2005) indica que a dança "Cielito Chopi" deve seu nome a uma ave, tem origem nas antigas danças denominadas "El cielo" ou "Cielito" da época do Mariscal Solano López (1826-1870), sendo também conhecida pelo nome de "Santa Fé". Segundo a pesquisadora:

O Chopi ou Santa Fé foram duas músicas diferentes. Como sua coreografia era a mesma, o tempo facilitou sua fusão. Na atualidade é conhecida como uma só dança, nomeada indistintamente Chopi, Cielito Chopi ou Santa Fé (...). Essa é a dança de conjunto mais conhecida, animada, alegre e de maior preferência no gosto popular (DOMINGUEZ, 2005 - tradução minha ${ }^{40}$ ).

\footnotetext{
${ }^{40}$ No original: El Chopi o Santa Fe fueron dos músicas diferentes. Como su coreografía era la misma, el tiempo facilitó su fusión. En la actualidad es conocida como una sola danza, nombrada indistintamente Chopi, Cielito Chopi o Santa Fe (...) Esa es la danza de conjunto más conocida, animada, alegre y de mayor preferencia en el gusto popular (DOMINGUEZ, 2005, online). Disponível no youtube em: https://www.youtube.com/watch?v=0q4DOAV2eHE\&t=716s (acesso janeiro 2021).
} 
O pesquisador Evandro Higa (2013) resgata o relato do juiz de direito José de Melo e Silva, da cidade Bela Vista, fronteiriça entre Brasil e Paraguay, no final da década de 1930, onde se que diz:

Entre os descendentes guaranis tudo é motivo para danças, inclusive acontecimentos fúnebres. A música é a polca paraguaia e o Chopin ou santa-fé. Predestinado para a arte dos sons, tem ele música própria, de ritmo peculiar, coisa típica e inflexível, e que não se submeteu, até hoje, a influências estranhas" (SILVA apud HIGA, 2013, p.80 - grifo no original).

Realizei as transcrições da polca "Cielito Chopi" a partir da gravação da Banda Koygua de Alejandro Cubilla na década de 1960. A partir das transcrições, escrevi as novas referências para a Orquestra Errante. Como já mencionei, desta vez realizei partiturascartazes individuais e, em vez de apresentar para cada músico/musicista os mesmos materiais, apresentei várias referências diferentes para cada participante, todas a partir de fragmentos da polca "Cielito Chopi".

Para a elaboração dessas novas partituras também levei em consideração as sugestões dos/as integrantes da Orquestra Errante para tentar uma notação hibrida, que partisse da escrita tradicional, mas permanecesse aberta para as interferências de cada participante. Além da liberdade de alterar os materiais sugeridos e acioná-los na ordem e tempo que quisessem, a quantidade de informação e os detalhes (o modo como estão escritos) em cada partitura-cartaz foi diferente. Adotei esses procedimentos para evitar uma possível sincronia de "leitura". Por exemplo, a partitura-cartaz que pianista Mariana Carvalho utilizou continha quatro referências como sugestões para improvisação, enquanto a partitura-cartaz utilizada pelo trombonista Fábio Martinelli continha três. As fotos a seguir ilustram ambas as partituras-cartazes. 


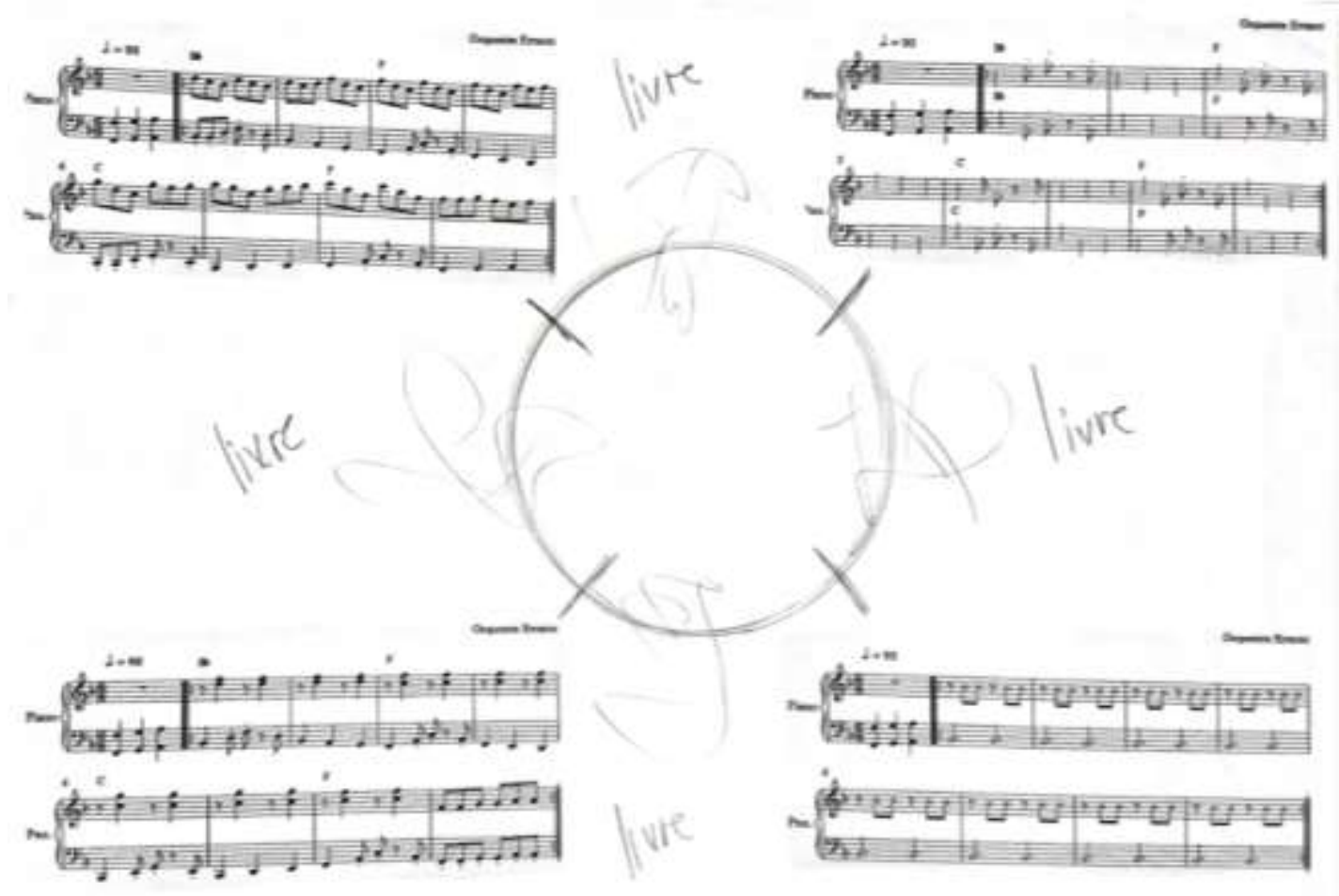

Figura 17. Partitura-cartaz apresentada ao piano

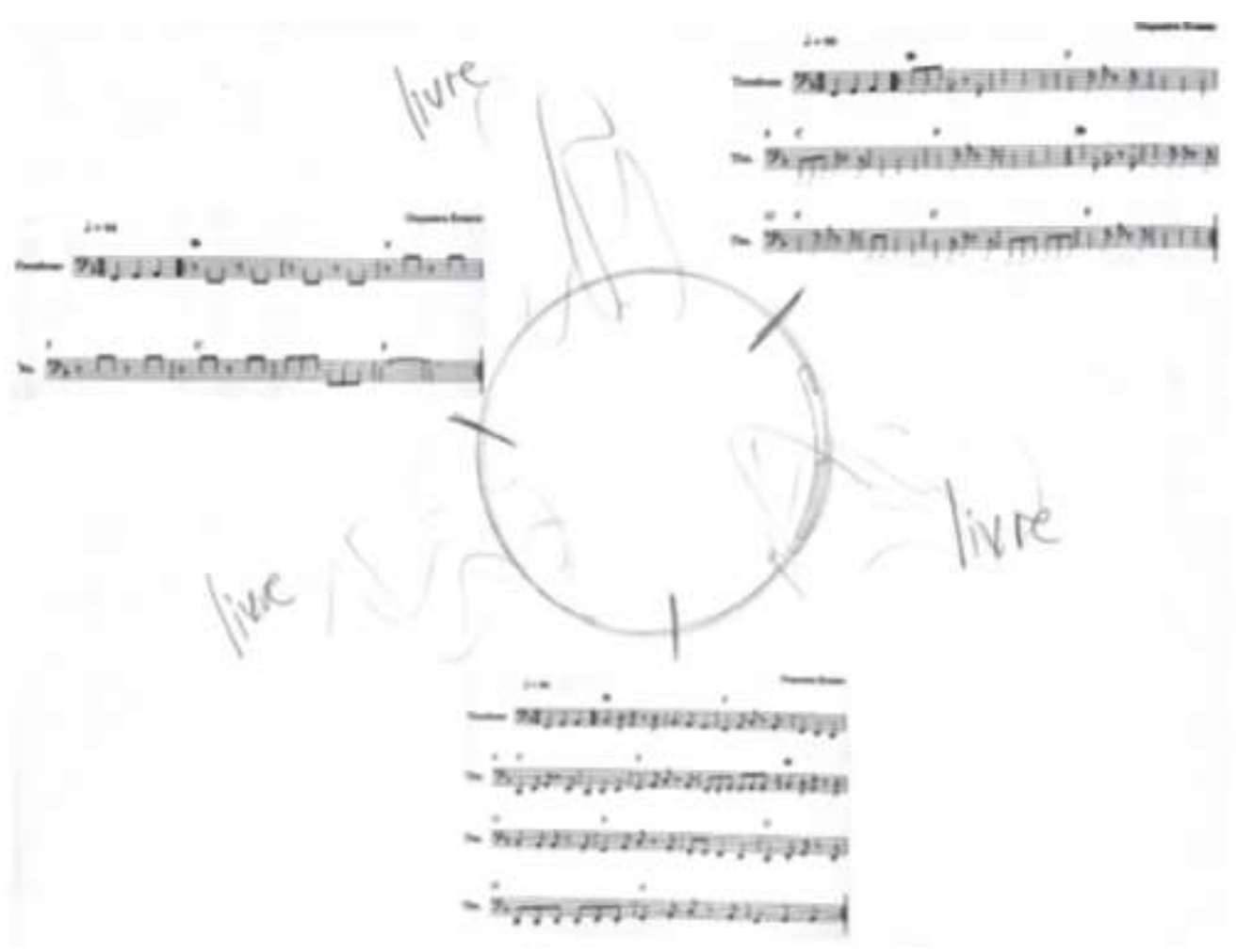

Figura 18. Partitura-cartaz apresentada ao trombone 
Dentre as experiências realizadas a partir dessa proposta destaco para audição duas improvisações gravadas pela Orquestra Errante durante os encontros no segundo semestre de 2018. Na primeira gravação ${ }^{41}$ participamos: Rogério Costa, saxofone alto; Mariana Carvalho, piano; Lucia Esteves, guitarra; e eu, no contrabaixo. Nesse registro se percebe o acionamento das referências e como elas contaminam o devir da improvisação. Percebem-se também os materiais estudados anteriormente como o padrão rítmico "silêncio de colcheia + duas colcheias"; a sobreposição de "duas batidas contra três" (duas semínimas pontuadas contra três semínimas); a alternância entre núcleos polarizadores como dominante e tônica, ademais de contínuas linhas de fugas. As interferências dos materiais (des)(re)territorializados configuram estados provisórios e transitórios que evocam memórias do idioma de onde foram retirados. A escuta e interação a partir da livre conexão e contaminação das referências - que durante a improvisação funcionam como referentes (COSTA, 2016) -, (re)direcionam o fluxo da improvisação na qual estados provisórios são formados mediante os materiais sugeridos.

A segunda gravação ${ }^{42}$ que destaco teve a participação de dez instrumentistas: Marina Mapurunga, viola; Rogério Costa, saxofone alto; Caio Righi, saxofone alto; Felipe Fraga, clarinete; Fabio Martinelle, trombone baixo; Natalia Francischini e Pedro Sollero, guitarras preparadas; Mariana Carvalho, piano; Denis Abranches, percussão e luteria experimental; e eu, ao contrabaixo.

A improvisação começa de forma livre. Por volta do minuto 1' aciono fragmentos das referências, com três notas ascendentes. Este referente ecoa no saxofone soprano aos 1'50", que insiste no material até que aos 3' ele já se tornou pregnante o bastante para gerar acumulação por camadas. As contaminações desse material logo são percebidas, desencadeando um estado provisório de exploração desses referentes por todo o grupo.

\footnotetext{
${ }^{41} \mathrm{~A}$ áudio da gravação se encontra disponível em: https://soundcloud.com/interferencias sonoras/cielito-chopi-i-interferencias-paraguayas-orquestraerrante

$42 \mathrm{O}$ áudio da gravação se encontra disponível em: https://soundcloud.com/interferencias sonoras/cielito-chopi-ii-interferencias-paraguayas-orquestraerrante
} 
Se configuram sincronias de pulsação e estados provisórios rítmicos e tonais, promovendo alternância entre núcleos polarizadores dominante e tônica. Todavia, interferências mais ousadas, como a que promove uma das guitarras a partir do ponto 4'30', conseguem desestabilizar o estado provisório (a sensação de sincronia de padrões rítmicos-melódicos) ocasionando difusão das ideias de novos direcionamentos ao fluxo. O saxofone soprano insiste no material que ainda se estica até a marca de 5', onde novamente as interferências de outros instrumentos como a guitarra e o piano diluem o estado anterior e redirecionam o fluxo da improvisação. A partir desse ponto se percebe um novo arco no qual o piano e o violino repetem os materiais que antes apareciam nos sopros e estes ecoam resquícios desses materiais transformados. Essa intervenção acaba diluindo o fluxo numa textura rarefeita (6') que, por sua vez, é redirecionada para uma espécie de "coda" ( $\left.7^{\prime}\right)$, onde o trombone baixo retoma fragmentos das referências e induz a sensação rítmica, porém o grupo não retoma nessa direção e acaba de tocar aos poucos, finalizando a improvisação aos 8'.

No artigo "Orquestra Errante: uma prática musical entranhada na vida" (2020), o Prof. Rogério Costa faz um relato da sua experiência com essas propostas de interferências paraguaias na Livre Improvisação:

O processo de interferência que envolve uma vivência emocional, racional e corporal com o repertório, passou pela audição de uma gravação, uma explicação sobre o seu contexto sociocultural e uma reprodução informal de canção pelo grupo (a partir da escuta e da leitura de uma partitura). Em seguida, realizamos várias performances em que deveríamos improvisar dialogando de alguma forma (através da utilização transformada de elementos rítmicos, melódicos, harmônicos, formais, de caráter etc.) com a vivência que tínhamos tido com a canção" (COSTA, 2020, p.325).

De forma geral, entendo que o grupo conseguiu explorar novas possiblidades de improvisação com referências paraguaias e, além disso, ampliou seu contato com a cultura paraguaia. De minha parte, acredito que revisitar músicas paraguaias conhecidas no Brasil também foi uma maneira de desfazer o estigma de interpretação que as torna uma espécie de paródia, como é o caso da polca "Galopera".

Ao discutir o caminho percorrido, a Orquestra Errante chegou ao consenso de que as partiturascartazes são úteis como um primeiro jogo de contato com as referências sugeridas, porém, depois de algumas experimentações com o material, é possível descartar o uso das partituras, 
outorgando assim maior liberdade ao acionamento e agenciamento das referências. As partituras-cartazes viabilizaram um modo de representar as estruturas abertas, ou seja, as comprovisações. Na minha opinião, foi uma etapa importante para aprofundar o estudo das referências paraguaias. Porém, dada a preferência da Orquestra por abordagens mais livres, com propostas sem partituras, mas que ainda possibilitassem o trabalho com música paraguaia, me senti motivado a explorar improvisações "livres" com o mote "memórias" ou "ressonâncias" dos estudos realizados até esse momento.

\subsubsection{RESSONÂNCIAS - EXPERIMENTOS SEM PARTITURAS}

Para as propostas a partir da ideia de "ressonâncias" não elaborei partituras nem sugeri diretrizes como referências. Simplesmente conversei com o grupo, lembrando algumas características da música paraguaia, as sessões de escuta e as abordagens que exploramos a partir das referências selecionadas até então. Nesse sentido, reiterei minha proposta de interferências paraguaias a partir do livre acionamento e manipulação de referências que, por vezes, criaram estados sonoros provisórios que ecoaram territórios tonais. Em outras palavras, materiais (des)(re)territorializados deveriam ser postos em jogo na Orquestra Errante. A partir dessa abordagem sem partituras e contando somente com a memória das experiências anteriores, passamos a explorar improvisações "livres-paraguaias".

Dentre as improvisações realizadas com a Orquestra Errante nessa etapa (segundo semestre de 2018) destaco duas gravações. Na primeira gravação ${ }^{43}$ sobressaem polarizações harmônicas como I IV V I (não necessariamente nessa ordem) e uma leve sincronia rítmica que gera a sensação de levada típica da polca com duas batidas contra três. Participaram dessa gravação: Rogério Costa, saxofone alto; Caio Righi, flauta

\footnotetext{
${ }^{43} \mathrm{O}$ áudio da gravação se encontra disponível em: https://soundcloud.com/interferencias sonoras/livrei-interferencias-paraguayas-orquestra-errante
} 
transversal; Mariana Carvalho, piano; Paola Picherzky, violão; Fabio Manzione, percussão; e eu, ao contrabaixo.

Na segunda gravação ${ }^{44}$ se percebem a utilização de padrões rítmicos estudados nos encontros anteriores, como "silencio de colcheia + duas colcheias" e a sobreposição de "duas semínimas pontuadas contra três semínimas". Também foram geradas camadas rítmicas mais densas como uma espécie de textura de elementos tercinados. Participaram dessa gravação: Rogério Costa, saxofone soprano; Caio Righi, flauta transversal; Mariana Carvalho, piano; Yonara Dantas, voz; Pedro Sollero, guitarra; Fabio Manzione, percussão; e eu, ao contrabaixo.

\subsubsection{AMPLIANDO O OLHAR SOBRE AS REFERÊNCIAS PARAGUAIAS}

As músicas escolhidas para serem investigadas no presente trabalho foram acionadas no sentido musical, a partir de fragmento de melodias, como já descrito, mas também no sentido extramusical, onde busquei entender os aspectos socioculturais impressos nas canções e que também tomaram parte dos trabalhos. Entender os contextos históricos, tanto das referências paraguaias que me interessam como dos procedimentos de Livre Improvisação que me são caros, foi um passo fundamental para realizar este estudo. Nesse viés, o levantamento de questões socio históricas foi um passo necessário nos processos criativos, na medida em que me permitiu amplificar as potencialidades das referências a partir do entendimento das marcas e resquícios históricos impressos nas músicas.

Uma das escolhas que foi perpassada por esses aspectos foi utilizar a Banda Koygua de Alejandro Cubilla como principal referência sonora para a Orquestra Errante. Foram as suas gravações que subsidiaram nossas investigações das músicas "Cielito Chopi",

\footnotetext{
${ }^{44} \mathrm{O}$ áudio da gravação se encontra disponível em: https://soundcloud.com/interferencias sonoras/livreii-interferencias-paraguayas-orquestra-errante
} 
"Galopera" e "Achuita". E a relevância dessas gravações no cenário musical paraguaio me fez estudar o contexto de formação e a história por trás da proposta de Alejandro Cubilla.

A história da música tradicional popular do Paraguay, que obviamente se vincula a história do próprio país, também é uma história de (des)(re)territorializações de sonoridades. Desde a colonização (que é a história a que temos acesso, não sendo, no entanto, o início da história musical do território paraguaio) diversas culturas locais e estrangeiras entraram em fricção por todo o continente. No Paraguay, restou o idioma guarani como herança dos povos originários, mas a cultura musical está muito mais próxima dos padrões estéticos dos colonizadores do que aqueles que alguma vez foram os "padrões locais".

O músico e pesquisador paraguaio Arturo Pereira (2011) escreve sobre o caráter impositivo do ensino musical nas reduções dos jesuítas e dos franciscanos nas Américas, denunciando seu uso como ferramenta de submissão e apaziguamento dos povos originários. A formação de alunos/as nas reduções promoveu a formação de bandas musicais, criadas para acompanhar atos litúrgicos e festas profanas. Com o tempo essas mesmas agrupações foram as responsáveis por sedimentar a cultura musical tradicional do Paraguay. Segundo o músico e pesquisador Mauricio Cardozo Ocampo (apud PEREIRA, 2011), nas reduções franciscanas se aplicava um método de educação musical mais liberal, combinando o religioso com o profano. É a partir da formação desses músicos/musicistas que o cenário musical do Paraguay começa a ser forjado.

Como a música se produz mediante os músicos [e musicistas], descobrimos também que esses foram os indígenas, depois os mestiços e filhos de mestiças e mestiços que eram diferentes dos chamados crioulos. É quando começa lentamente a se produzir o caráter profano das manifestações populares e se descola lentamente da influência da Igreja, incorporando-se nas agrupações musicais os elementos rítmicos das danças nativas ancestrais. É nesse sincretismo de lenta produção no tempo, onde podemos encontrar a "gênese da Música Paraguaia" (PEREIRA, 2011, p.35 - grifo no original - tradução minha ${ }^{45}$ ).

\footnotetext{
45 No original: Como la música se produce mediante los músicos, descubrimos también que éstos eran os indígenas, luego los mestizos e hijos de mestizas y mestizos ya diferenciados de los llamados criollos. Es cuando comienza lentamente a producirse el carácter profano de las manifestaciones populares, y
} 
A partir da independência do Paraguai em 1811 e com a constituição de organismos oficiais de Estado, a formação musical passa a estar vinculada à formação militar. Dessa relação se originaram as "Bandas de Música do Paraguay", agrupações tradicionais muito importantes para a manutenção e transmissão da música paraguaia. 0 pesquisador paraguaio Luis Szarán (1999) cita algumas bandas famosas do século XIX e suas relações com as instituições militares do Paraguay ao lembrar que a grande maioria dos integrantes das bandas de música popular tiveram sua formação musical nas instituições militares.

Paralelamente coexistem desde finais do século passado (XIX) as bandas populares "Okara de Pinozá", "Hy'ekue de Trinidad" e, desde a década de 1950 as bandas "Valenzuela", "[Bandita] Koygua de Alejadro Cubilla", la "Bandita de Luque de Chiquitín Cuéllar", la "Bandita de San Lorenzo" entre outras (SZARÁN, 1999, p.77 - grifo meu - tradução $\left.\operatorname{minha}{ }^{46}\right)$.

Para o pesquisador paraguaio Arturo Pereira (2011) as bandas militares exerceram um papel decisivo para a formação e transmissão da música no país, pois "se constituíram em um verdadeiro pedestal que sustentou a origem, o desenvolvimento e a formalização da Música Paraguaia, e foram as instituições musicais vínculo e produto de acontecimentos trágicos e gloriosos na nossa história social” (PEREIRA, 2011, p.75 tradução minha ${ }^{47}$ ).

É desse contexto de bandas populares que se dedicam à música tradicional do Paraguay que selecionei uma referência muito importante nesta pesquisa: a Banda Koygua, de Alejandro Cubilla, e mais especificamente os dois discos gravados pelo grupo na década

desprendiéndose lentamente de la influencia de la Iglesia van incorporándose a estas agrupaciones musicales los elementos rítmicos de sus ancestrales danzas nativas. $Y$ es en esa sincretización de lenta producción en el tiempo donde podemos encontrar la "génesis de la Música Paraguaya" (PEREIRA, 2011, p.35).

${ }^{46}$ No original: Paralelamente coexisten desde finales del siglo pasado las bandas populares Okara de Pinozá, Hy'ekue de Trinidad y, desde la década del 50 las bandas Valenzuela, Koygua de Alejandro Cubilla, la Bandita de Luque de Chiquitín Cuéllar, la Bandita de San Lorenzo y otras (SZARÁN, 1999, p.77)

47 No original: (...) se constituyeron en un verdadero pedestal en los que se sostuvieron el origen, desarrollo y formación de la Música Paraguaya y fueron las instituciones musicales vinculo y producto de acontecimientos trágicos y gloriosos de nuestra historia social (PEREIRA, 2011, p.75). 
de 1960, material musical que eu costumava escutar reiteradamente junto com meu avô, Pedro Antar.

\subsubsection{AlEjANDRO CUBILlA: DE Músico MILITAR A MILITANTE} SOCIALISTA

Alejandro Cubilla (1929-2016) foi filho de um reconhecido regente de bandas militares, Rogelio Cubilla (1903-1958). Em 1941, aos 12 anos, Alejandro ingressou na "Banda de la Policía" de Paraguay e em 1948 passou a integrar a "Banda de la $1^{\circ}$ División de Caballería", até 1951, quando foi demitido por não aceitar se afiliar ao Partido Colorado, pois naquela época ele já frequentava as reuniões do "Partido Revolucionario Febrerista", principal grupo de oposição. Aqui é importante lembrar a conturbada vida política do Paraguay naquele período, tendo enfrentado uma guerra civil em 1947 e pouco depois, em 1954, vivenciado o início de um período de ditadura militar que perduraria até 1989.

Após seu desligamento do exército, em 1951, Alejandro fundou a "Orquestra Alex Cull y sus caballeros del jazz", grupo com o qual alcançou grande sucesso. A repercussão foi tamanha que, um tempo depois, foi chamado de volta por antigos camaradas militares que nesse interim haviam sido promovidos a chefes na Comandância da Cavalaria do exército paraguaio. Foi assim que Alejandro atuou como regente do "Conjunto Orquestral de la $1^{\circ}$ División de Caballería" (SZARÁN, 1999, p.156) entre os anos 1956 a 1960. Porém, novamente por pressões políticas, teve que afastar-se novamente das atividades musicais militares.

Em paralelo às atividades no exército, por volta de 1957, Alejando Cubilla fundou sua "Banda Koygua", dedicada ao repertório tradicional com arranjos instrumentais para naipe de sopro (trompetes, saxofones, clarinete, trombone, tuba) e percussão (bumbo, caixa e pratos). A palavra "koygua" é de origem guarani e significa "camponês". A proposta de Ajelandro Cubilla com sua Banda Koygua era resgatar a tradição das antigas bandas musicais que acompanhavam as festas e procissões no interior do Paraguay. 
Além de atuar nas datas festivas do país, a Banda Koygua "se tornou número imperdível de Festivais a favor dos Direitos Humanos e da liberdade" (PortalGuarani, online tradução minha ${ }^{48}$ ), atuando ao lado de outros importantes nomes latino-americanos como Mercedes Sosa (1935-2009) e Eladio Martinez (1912-1990). Foi por causa da sua militância política contra o ditador Alfredo Stroessner (1912-2006) que, em 1974, Alejandro sofreu um atentado sendo agredido fisicamente por um grupo de simpatizantes do governo. Os golpes sofridos na ocasião foram de tamanha violência que provocaram o desprendimento das retinas dos olhos, desencadeando um problema de glaucoma e consequente perda da visão pelo músico.

Histórias como essa e tantas outras são o pano de fundo de onde emergem a música, a cultura e a arte paraguaia, assim como se observa em boa parte da música popular latino-americana. Não podem ser menosprezadas como aspectos extramusicais, pois são parte fundamental desse fazer musical. Como mencionei anteriormente, observar as questões envolvidas nas referências paraguaias que acionei neste trabalho, enriqueceram, ou melhor, potencializaram os processos criativos permitindo um encontro musical que - se não permitia uma imersão completa no cancioneiro paraguaio - tampouco poderia reiterar apagamentos.

Essa perspectiva de trazer proposições extramusicais ao espaço da criação musical dialoga ainda com aquilo que o Prof. Rogério Costa defende para a Livre Improvisação, aproximando-a de ideias políticas autonomistas, autogestionárias e libertárias. "É um lugar do pensamento menor, de heterotopias, na medida em que está sempre procurando fugir das hegemonias e das estruturas de poder" (COSTA, 2017, p.71). Nesse contexto, a dicotomia popular/erudito se dilui para abrir caminho a uma outra forma de relação, na qual consigo aproximar, ou melhor, colocar em interferência minhas referências paraguaias com os processos de improvisação e criação coletiva.

\footnotetext{
48 No original: (...) fue número infaltable de los Festivales a favor de los Derechos Humanos y de la libertad (PortalGuarani, online, acesso janeiro 2021).
} 
Nesta parte do trabalho apresento as performances criadas pela Orquestra Errante e a KairosPania Cia. Cênico Sonora, que envolveram outras disciplinas artísticas e também partiram de músicas paraguaias que utilizamos como disparadoras dos processos criativos. É talvez nesses trabalhos que os estudos de aspectos sócio históricos da cultura paraguaia, e de questões como violência, apagamento e ressignificação foram acionadas de maneira mais contundente.

3.1 COMPROVISAÇÃO: UM MODO DE CRIAÇÃO INDISCIPLINAR. KAIROSPANIA CIA. CÊNICO SONORA E ORQUESTRA ERRANTE

A KairosPania Cia. Cênico Sonora é uma companhia artística que se dedica ao diálogo indisciplinar, isto é, além da interdisciplinaridade no propósito de diluir das fronteiras entre práticas artísticas. O trabalho da KairosPania Cia. Cênico Sonora se inicia em 2016 a partir do desejo de criar coletivamente entre artistas de dança, teatro, artes plásticas, música, live electronics e audiovisual.

A KairosPania Cia. Cênico Sonora tem fortes vínculos com o NuSom e a Orquestra Errante, pois vários de seus/suas integrantes também participam desses grupos de estudos. Nesse sentido, a indisciplinaridade artística da companhia se fundamenta nas pesquisas sobre performance, as relações dos corpos e os espaços (convencionais ou não) como material estético junto com a música, ao som e ao ruído, na esteira dos estudos em Sonologia. 
Nesses quase cinco anos de atividades, a KairosPania teve participação dos seguintes artistas (dispostos em ordem alfabética): Anna Kobzareva, Carmen Estevez, Fábio Manzione, Filipe Augusto, Kelly Caldas, Lara Kadocsa, Natalia Francischini, Samya Enes, Tarita de Souza, Victor Pessoa, Yonara Dantas, e eu. Além de ter contado com a colaboração de Luzilei Aliel em muitas de suas performances.

O nome do grupo cria um amalgama com as palavras Káıpos (Kairós), do grego, que se refere a um tipo específico de tempo, e Companhia, nome dado a um coletivo teatral. Kairós não é o tempo do relógio, "cronos", que metodicamente conta os minutos, as horas, os dias, os meses e os anos. Kairós, na verdade, se refere a um tempo oportuno ou nas palavras de Giorgio Agamben, tempo messiânico. É o tempo em que uma conjunção de fatores se revela favorável para que algo aconteça. É nesse sentido que a KairosPania Cia. Cênico Sonora desenvolve seu trabalho promovendo encontros criativos, disparando processos de pesquisa e imersão tendo como linha condutora procedimentos experimentais como a Livre Improvisação, jogos cênicos, exercícios corporais, experimentações em artes plásticas e processamentos eletrônicos em tempo real de imagens e sons.

O tipo de processo criativo desenvolvido pela KairosPania encontra referência em um dos artigos produzidos pelo Prof. Rogério Costa (2017) que apresenta uma classificação ${ }^{49}$ preliminar de contextos artísticos que se fundamentam (ou que estão fortemente ligados) em processos de consistência da Livre Improvisação. Ao se referir ao trabalho de criação coletiva e colaborativa, o Prof. Costa relaciona essas abordagens com a comprovisação e a interdisciplinaridade que caracterizam essas práticas.

(...) intérpretes são chamados a colaborar de forma criativa (improvisando) em peças compostas (às vezes em processos de criação coletiva) em tempo diferido, eventualmente, interagindo com dispositivos eletrônicos durante a performance. Em alguns casos as performances são multimidiáticas (incorporam artes visuais, vídeos, movimento, dança etc.). Geralmente, existe um planejamento composicional macroscópico (formal) anterior, mas os detalhes (nível

\footnotetext{
49 “As categorias propostas não são necessariamente excludentes uma vez que os limites entre elas não são claros, sendo que muitas delas se interpenetram e que é comum encontrar artistas e grupos que atuam em mais de uma das modalidades descritas" (COSTA, 2017, p.8)
} 
microscópico: dinâmicas, durações, frequências, sonoridades etc.) são resolvidos (interativamente, a partir de regras pré-estabelecidas e através de uma escuta intensificada) em tempo real durante a performance (COSTA, 2017, p.9-10).

Os níveis macroscópico (composição) e microscópico (improvisação), de modo geral, se relacionam com o levantamento de potenciais diretrizes durante os processos de experimentação (composição), colocadas em jogo por meio do seu agenciamento coletivo. Ao longo dos encontros de ensaio/experimentação, tais diretrizes vão sendo testadas, mantidas ou descartadas, chegando a uma espécie de canovaccio (termo oriundo da Comédia del Arte, se refere a um roteiro sobre o qual o elenco improvisa) que oferece um certo sentido para as ações desenvolvidas na performance.

Nas criações de performances realizadas pela KairosPania Cia. Cênico Sonora - em parceria direta ou indireta com a Orquestra Errante $^{50}$ - esses dois níveis (composição e improvisação) se retroalimentam durante dos processos criativos. Uma referência é apresentada e explorada em jogos de improvisação. Depois das experimentações o grupo (ou os grupos) conversa sobre o jogo realizado, levanta novas possibilidades para a referência inicial, ou mesmo propõe a testagem de novas referências. Elas podem servir de diretrizes para uma nova rodada de jogos onde essas ideias são exploradas por meio de outros jogos de improviso. Na medida em que os jogos avançam, se percebe que determinadas estruturas são importantes e, segundo consenso do grupo (ou dos grupos), se chega a uma estrutura comprovisatória - com diretrizes que sugerem certa

\footnotetext{
50 Os dois grupos teceram parceria direta nas performances "TransPosições" (2016), "Suíte [en]quadrada" (2016-2017), “Des a grad a vel” (2017), “A Síria não é aqui" (2017) e "Sinfonieta de abertura” (2017). Nessas performances, parte do trabalho era desenvolvido pela KairosPania, parte pela Orquestra Errante, e outra parte ainda pelo Luzilei Aliel em sua intervenção como live electronics. Os/as artistas que participam de ambos os grupos - KairosPania e Orquestra Errante - teciam uma ponte entre os processos de criação desenvolvidos em cada um dos grupos e promoviam o amálgama necessário para a execução do projeto. Luzilei, por seu turno, acompanhava alguns ensaios da KairosPania, dialogava comigo e com a Yonara que comumente dirigimos as performances.

A parceria indireta entre Orquestra Errante e KairosPania se deu na performance Delfina (2018). Nesse caso, a performance foi desenvolvida nos encontros da KairosPania, com profusão de métodos criativos advindos da Orquestra Errante, mas somente atuaram os membros que participaram do início ao fim do processo de criação.
} 
direcionalidade, mas aberta a escolhas e propostas que serão acionadas de forma original em cada atuação -, que é o plano geral da performance.

Mantém-se, assim, aquilo que Renato Cohen (2013) entende como fundamento da performance: ela não se repete - mesmo com alguns combinados prévios, cada execução é única. Pensando desde a perspectiva da performance, ela se desfaz quando acaba. O registro (fotográfico ou audiovisual) não é a performance, mas um documento que pereniza apenas uma das possibilidades de execução.

Isso também se relaciona com o modo de criação que na KairosPania Cia. Cênico Sonora e na Orquestra Errante nomeamos como comprovisação, pois mesmo chegando a um "plano composicional" que baliza a "estrutura" da performance, a cada execução novas possibilidades podem ser descobertas e outras deixadas de fora. Por isso, cada execução é uma atualização.

Sobre tais procedimentos, o pesquisador Sandeep Bhagwati (2013) observa a relação entre composição e improvisação a partir da distinção entre elementos "independentes do contexto" e que por isso permanecem mais ou menos semelhantes entre diferentes performances, e elementos considerados "contingentes" a uma determinada performance (BHAGWATI; 2013). Para o pesquisador Bhagwati, a comprovisação abrange os vieses dessas duas categorias, sendo considerada uma atividade criativa baseada em um "intertravamento esteticamente relevante de elementos performáticos contingentes e elementos independentes do contexto" (BHAGWATI, 2013, p.171 tradução minha ${ }^{51}$ ), com a seguinte ressalva:

A frase-chave nesta definição é "esteticamente relevante", pois aponta para a necessidade de um engajamento consciente, por parte dos/as participantes em um determinado contexto musical, com a dicotomia repetível/contingente que permeia as práticas criativas musicais contemporâneas (BHAGWATI, 2013, p.171 - tradução minha ${ }^{52}$ ).

\footnotetext{
${ }^{51}$ No original: aesthetically relevant interlocking of context-independent and contingent performance elements (BHAGWATI, 2013, p.171).

52 No original: A key phrase in this definition is "aesthetically relevant"; it points to the necessity of a conscious engagement, by participants in a given musicking context, with the repeatable/contingent dichotomy that pervades contemporary creative music practices (BHAGWATI, 2013, p.171).
} 
O engajamento necessário para várias pessoas agenciarem uma performance diz respeito justamente ao caráter coletivo da comprovisação. Segundo o pesquisador Marcel Cobussen (2017), a comprovisação não promove "uma análise, interpretação ou mero encontro reduzido a um ou mais constituintes individuais da improvisação, mas ao contrário, considera os comportamentos coletivos e inter-relacionados desses constituintes" COBUSSEN, 2017, p.25 - tradução minha ${ }^{53}$ ).

A colaboração direta entre a KairosPania Cia. Cênico Sonora e a Orquestra Errante na criação das performances ocorreu não somente pela participação de pessoas como Yonara Dantas, Natália Francischini, Fábio Manzione e eu que atuamos diretamente em ambos os grupos (o que nos permitia "conectar" os processos criativos entre os grupos), mas principalmente pela participação das demais pessoas da orquestra na "reta final" dos processos de criação e execução das performances (ver nota de rodapé ${ }^{50}$ sobre participação direta e indireta). Nesse sentido, a organização dos trabalhos de investigação e dos processos criativos ocorreram, de maneira geral, em duas frentes. Como primeira etapa, realizamos encontros semanais com a KairosPania Cia. Cênico Sonora onde foram apresentados ${ }^{54}$ e discutidos os "temas" ou "motes" que eventualmente direcionariam as criações, como as referências paraguaias que apresentei ao grupo. Exploramos possiblidades (de espaços, de gestos, de imagens, de sons etc.) a partir de pontos levantados no processo de pesquisa e criação do grupo KairosPania Cia. Cênico Sonora. Paralelamente a esse processo, também levantamos possíveis diretrizes para os/as músicos/musicistas da Orquestra Errante, que é a outra frente de trabalho. Essas diretrizes eram exploradas pela orquestra como uma primeira etapa de "estudo", mas esse processo ainda não se configurava como "ensaio" da proposta.

\footnotetext{
${ }^{53}$ No original: an analysis, interpretation, or mere encounter should not be reduced to one or more of the improvisation's individual constituents, but, on the contrary, should take the collective and interrelated behaviours of these constituents into account (COBUSSEN, 2017, p.25).

${ }^{54} \mathrm{Em}$ alguns casos os "temas" ou "motes" partiram das próprias chamadas de participação em eventos artísticos, como a série ¿Música?, do NuSom.
} 
A partir de certa etapa do processo criativo com a KairosPania Cia. Cênico Sonora quando algumas imagens de composição começavam a tomar forma -, apresentávamos a proposta para a Orquestra Errante e iniciávamos o processo criativo musical juntamente com a orquestra durante os encontros semanais. Ao fim deste processo, geralmente marcávamos encontros extras com os dois grupos (KairosPania Cia. Cênico Sonora e Orquestra Errante), "juntávamos" as partes e "ensaiávamos" a performance. Ensaiar a performance? Seria, talvez, mais correto dizer "estudávamos". Isso porque, neste caso, esses encontros serviam para que pudéssemos nos (re)conhecer entre todos, combinar e explorar possibilidades de interação a partir da estrutura comprovisatória elaborada durante o processo criativo.

Para o presente trabalho, selecionei dentre as performances desenvolvidas entre esses grupos aquelas em que utilizamos músicas, temas ou motes de origem paraguaia como disparadores do processo de criação. Vamos a elas:

\subsection{PERFORMANCE "DES A GRAD A VEL"}

A performance "Des a grad a vel" é uma criação da Orquestra Errante e a KairosPania Cia. Cênico Sonora, com colaboração de Luzilei Aliel, em resposta à chamada para participação na décima segunda edição da série ¿Música? ${ }^{55}$ realizada pelo NuSom. A décima segunda edição ocorreu em maio de 2017 e teve como proposta crítica e reflexão políticas de cerceamento dos espaços de convivência na ECA USP. Alguns meses antes, em dezembro de 2016, haviam sido instaladas grades em volta da "Prainha" da Escola de Comunicações e Artes (ECA) da USP, um espaço de cerca de mil metros quadrados, situado entre os fundos da Reitoria e os fundos do prédio central da ECA. Nele se encontram, além de uma área verde com bancos e árvores, um edifício de andar

\footnotetext{
${ }^{55}$ A série ¿Música?, realizada desde 2005 pelo NuSom, integra prática artística colaborativa e reflexão crítica sobre a produção em música e arte sonoro. Nas apresentações se misturam diferentes formas artísticas como música eletroacústica, instalação sonora, improvisação livre, performances e intervenções em espaços públicos.
} 
térreo que alberga o Sindicato dos Trabalhadores da USP (Sintusp), o Centro Acadêmico Lupe Contrim (Calc) dos/as estudantes da escola, a ECAtlética e um restaurante que aluga parte do edifício do Calc. Após a instalação da grade, o acesso ao espaço público passou a ocorrer apenas pelo prédio da ECA, e em determinados dias e horários passava a ser restrito unicamente aos/às alunos/as e funcionários/ias com "carteirinha". Nesse contexto, a chamada para participação na décima segunda edição da série ¿Música?, indicava que essas medidas:

[parecem] reverberar tendências políticas que têm se instalado tanto no cenário brasileiro como internacional. Nesse sentido, compreendemos que a Sonologia é um campo vocacionado à diversidade, abarcando diversas áreas do conhecimento, como demonstra a diversidade do nosso grupo de pesquisa, e, assim, pode se constituir como um campo de enfrentamento às direções políticas supracitadas. Dessa forma, abrimos a chamada para ¿Música? \#12 com o tema: Trânsitos e Cancelas (Chamada interna, NuSom, 10 de abril de 2017).

A chamada propunha que as performances ocupassem a área externa em frente ao Departamento de Música, algumas salas do departamento e a área externa do prédio que compartilham o Departamento de Artes Cênicas com o Departamento de Música, na parte posterior de ambos os prédios.

Cientes da proposta disparadora do evento, buscamos pesquisar e nos aprofundar nos paralelos entre essas iniciativas de (de)limitação dos espaços e imposições autocráticas à circulação de pessoas nas dependências da ECA USP com movimentos sociais mais amplos, como as iniciativas de coerção e segregação social impostas aos movimentos migratórios intensificados pela guerra na Síria. Partimos de uma experiência cotidiana vivida no próprio espaço da ECA USP para pensar em outras e certamente mais agressivas cancelas e grades que estavam se levantando mundo afora.

Somava-se a isso que, na época, o então presidente dos Estados Unidos, Donald Trump, estava empenhado na construção de um muro contra os imigrantes na fronteira com Mexico. Também observávamos a oposição de alguns países ao Pacto Global para Migração, uma iniciativa com o objetivo de promover maior cooperação entre as nações para lidar com a migração de forma eficaz, não fazendo distinção entre os direitos concedidos aos migrantes regulares e irregulares, ou entre migrantes econômicos e refugiados. No Brasil, vivenciamos a implementação de operações policiais como a 
"Operação Muralha", uma série de barreiras promovidas pelo exército (e não pela Polícia Rodoviária) para intensificar o controle nas rodovias que ligam Brasil ao Paraguay.

Com o grupo KairosPania Cia. Cênico Sonora decidimos ocupar os fundos do pátio compartilhado entre o Departamento de Música e o Departamento de Artes Cênicas. Naquele lugar, o portão que separa o pátio compartilhado entre os departamentos e a Praça do Relógio nos pareceu oferecer um material potente para trabalhar a questão da separação entre as pessoas. Nesse sentido, todos os "ensaios" ou melhor, os encontros durante o processo criativo, foram feitos naquele local, configurando no final do processo uma performance site specific.

\section{MAPA CÉNICO}

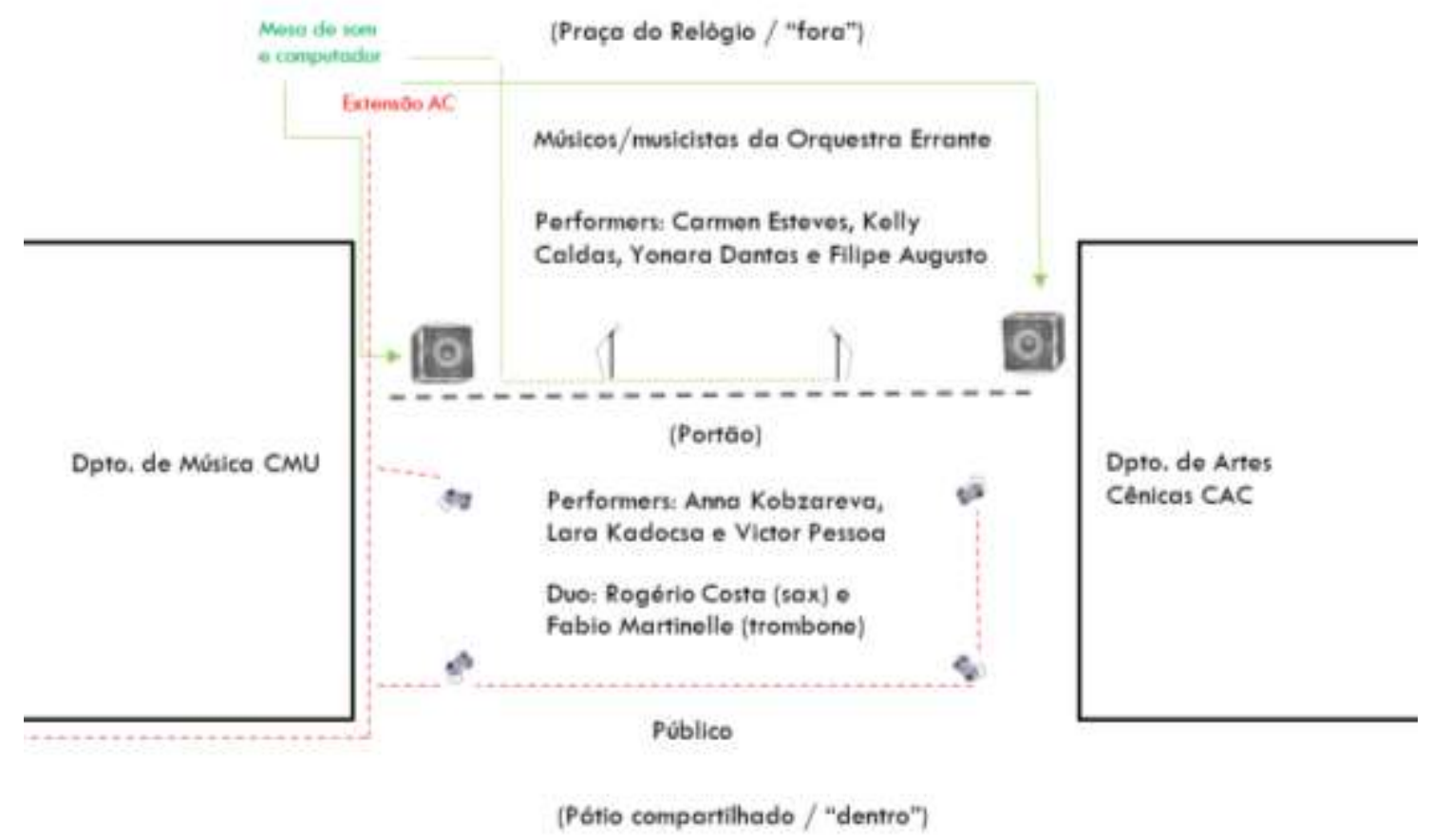

Figura 19. Mapa cênico desenvolvido para a performance "Des a grad a vel"

A disposição espacial que exploramos a partir do portão nos permitiu criar uma sensação de "dentro e fora", pois utilizamos o espaço dentro do pátio e o espaço fora dele, ou seja, na Praça do Relógio. Os espaços de dentro e de fora são bastante diferentes, em termos de piso e de iluminação e, consequentemente, nos ofereciam desde já um cenário profícuo para compormos nossa narrativa. Os espaços são divididos justamente 
por um portão fechado - como uma grade, um muro. Além disso, cobrimos com mantos pretos algumas das luzes da Praça do Relógio que ficam perto do portão, de forma que - lado de "fora" ficasse na escuridão, ao contrário que o lado de "dentro" onde reforçamos a iluminação do local com luzes extras.

Durante o processo criativo com a KairosPania Cia. Cênico Sonora recolhemos imagens e depoimentos de refugiados que depois foram acionados na performance. Para isso, imprimimos os depoimentos em pequenas tiras de papel que, embaralhados, foram repartidos aleatoriamente entre as performers que estariam de lado de "fora" da grade, como que esperando que se abrissem para entrar (Carmen, Kelly, Yonara e Filipe). Durante a performance, eles liam os depoimentos que, depois de lidos, iam sendo depositados na grade enquanto performers situadas do lado de "dentro" (Anna e Lara) reforçavam as "fronteiras" com retalhos de tecido negro (que remetiam também à cicatrizes impressas nas grades). De forma complementar, o músico de live electronics Luzilei Aliel, desempenhava uma proposta semelhante ao disparar trechos de depoimentos gravados, processando-os em tempo real.

Também do lado de "dentro", junto ao público, o performer Victor Pessoa, estava sentado numa cadeira, ao lado de uma pilha de jornais. Em um determinado momento, ele começava a mexer nas folhas, primeiro folheando-as devagar e, aos poucos, intensificando o ritmo de manuseio com os papeis até passar de um jornal a outro de forma intensa e abrupta, criando uma "chuva de notícias" que se espalhavam no chão. Perto dele, dois músicos da Orquestra Errante (Rogério Costa e Fábio Martinelle) improvisam a partir de fragmentos de uma música paraguaia que sugeri como referência para esse trabalho. Enquanto isso, do lado de "fora", os depoimentos continuavam sendo relatados, a grade continuava sendo "reforçada" pelos retalhos de tecido negro. No dia da performance, que foi após do pôr do sol, as tiras de tecido negro, somadas ao breu da parte de fora da grade, ampliaram a invisibilidade de quem estava do lado de "fora".

Musicalmente, na parte de "dentro", músicos improvisavam a partir da guarânia "Lejania". Já os músicos dispostos da parte de fora improvisavam livremente citações 
dos padrões rítmicos da música paraguaia, como que tentando conversar com a parte de dentro.

O público ficava situado do lado de dentro do "território", olhando com clareza os jornais voando, os músicos de "dentro" tocando, as performers intensificando a grade e vendo se apagarem paulatinamente os performers dispostos do lado de fora, condenados à escuridão intensificada pelos tecidos que reforçavam a grade. Somente o som vindo da parte externa insistia em lembrar que eles seguiam ali, como que à espera de uma oportunidade.

\subsubsection{SOBRE A REFERÊNCIA MUSICAL: GUARÂNIA “LEJANIA".}

A referência paraguaia que propus trabalhar nessa performance foi a guarânia "Lejania", composta em 1937 por Herminio Gimenez (1905-1991), destacado compositor e regente de orquestra. De modo semelhante a muitos músicos paraguaios, Gimenez teve sua formação musical nas instituições militares, chegando a ser regente de bandas militares. No entanto, devido a sua postura contrária ao regime do ditador Alfredo Stroessner, foi desvinculado e obrigado a deixar o país em 1970 para viver em exílio na Argentina, voltando ao país apenas em 1989, após a queda da ditadura.

Escolhi a guarânia "Lejania" como referência devido a temática apresentada na letra, que trata de amor, separação, memória e reconhecimento. E também porque essa música é muito popular tanto no Paraguay como no Brasil, sendo que a versão em português de José Fortuna e Pinheiro Júnior, aqui conhecida como "Meu primeiro amor", e que ficou famosa a partir da gravação de Cascatinha e Inhana de 1952.

Além disso, a história mesma dessa guarânia repõe uma história de apagamentos, ela é um exemplo de apagamento da identidade paraguaia no Brasil. Ela é resultado de uma política de estado, como indica o pesquisador Evandro Higa (2013). Para ele, a postura do governo brasileiro durante a década de 1940 com políticas nacionalistas e tendências imperialistas apontavam "uma aspiração do país à hegemonia no continente, mais do 
que uma efetiva parceria. A cultura dos demais países da América Latina era concebida como um campo a ser conquistado, mais do que reconhecido" (HIGA, 2013, p.55). Ao referir-se especificamente à guarânia "Lejania", o pesquisador indica:

(...) a célebre gravação da guarânia "Meu primeiro amor" (versão da guarânia paraguaia "Lejania" de Hermínio Gimenez, feita por José Fortuna e Pinheiro Jr. e registrada no disco Todamérica TA-5179) feita por Cascatinha e Inhana em 1952 estava registrada como "canção" e não como "guarânia". Essa situação se repetiu muitas vezes, principalmente quando se tratava de versões brasileiras de guarânias paraguaias" (HIGA, 2013, p.101).

Isso revela uma tendência de apagamento sistemático das referências que apontam a origem paraguaia de canções regravadas no Brasil. Além disso, em 2009, a guarânia "Lejania" foi alvo de notícias nos principais jornais paraguaios e brasileiros por consequência de uma nota jornalística ${ }^{56}$, apresentada no programa "Fantástico" da Rede Globo no dia 29 de novembro daquele ano. Na reportagem, se omitia a origem paraguaia da música. Na ocasião a embaixada paraguaia solicitou o esclarecimento e retratação frente ao ocorrido, que foi realizada uma semana depois também no programa "Fantástico".

Para utilizar a guarânia "Lejania" como referência no processo criativo da performance "Des a grad a vel", realizei a transcrição de fragmentos da melodia em duas páginas de cartolina (uma para cada músico) que serviram de diretriz para Rogério Costa (saxofone alto) e Fábio Martinelle (trombone baixo). De maneira proposital omiti alguns parâmetros de escrita nos fragmentos de melodia que sugeri, de modo a reforçar a ideia de liberdade na execução e transformação das diretrizes por parte dos músicos Rogério Costa e Fabio Martinelle.

\footnotetext{
${ }^{56}$ Disponível nos seguintes links: https://www.douradosnews.com.br/noticias/rede-globo-corrigira-erroque-irritou-paraguaios-acc8535754252ad871c49/375067/ (acesso janeiro 2021); https://noticias.uol.com.br/ultnot/internacional/2009/12/04/ult1859u1996.jhtm (acesso janeiro 2021); https://paraguaiteete.wordpress.com/2011/04/06/a-rede-globo-se-retrata-sobre-a-autoria-daguarania/ (acesso janeiro 2021).
} 


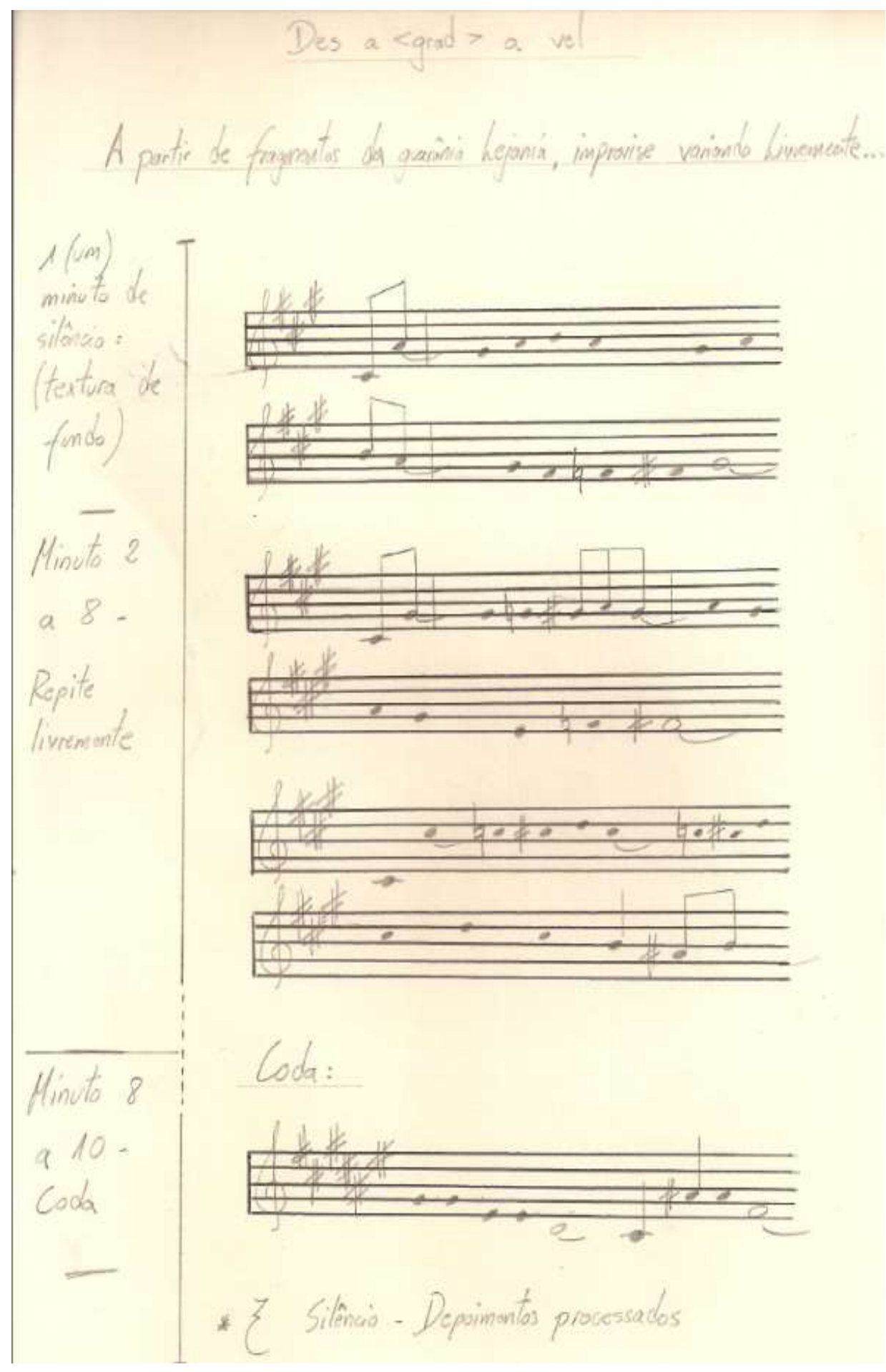

Figura 20. Partitura com as diretrizes para Rogério Costa (saxofone alto) 


$$
\text { Des a rarad }=\text { a vel }
$$

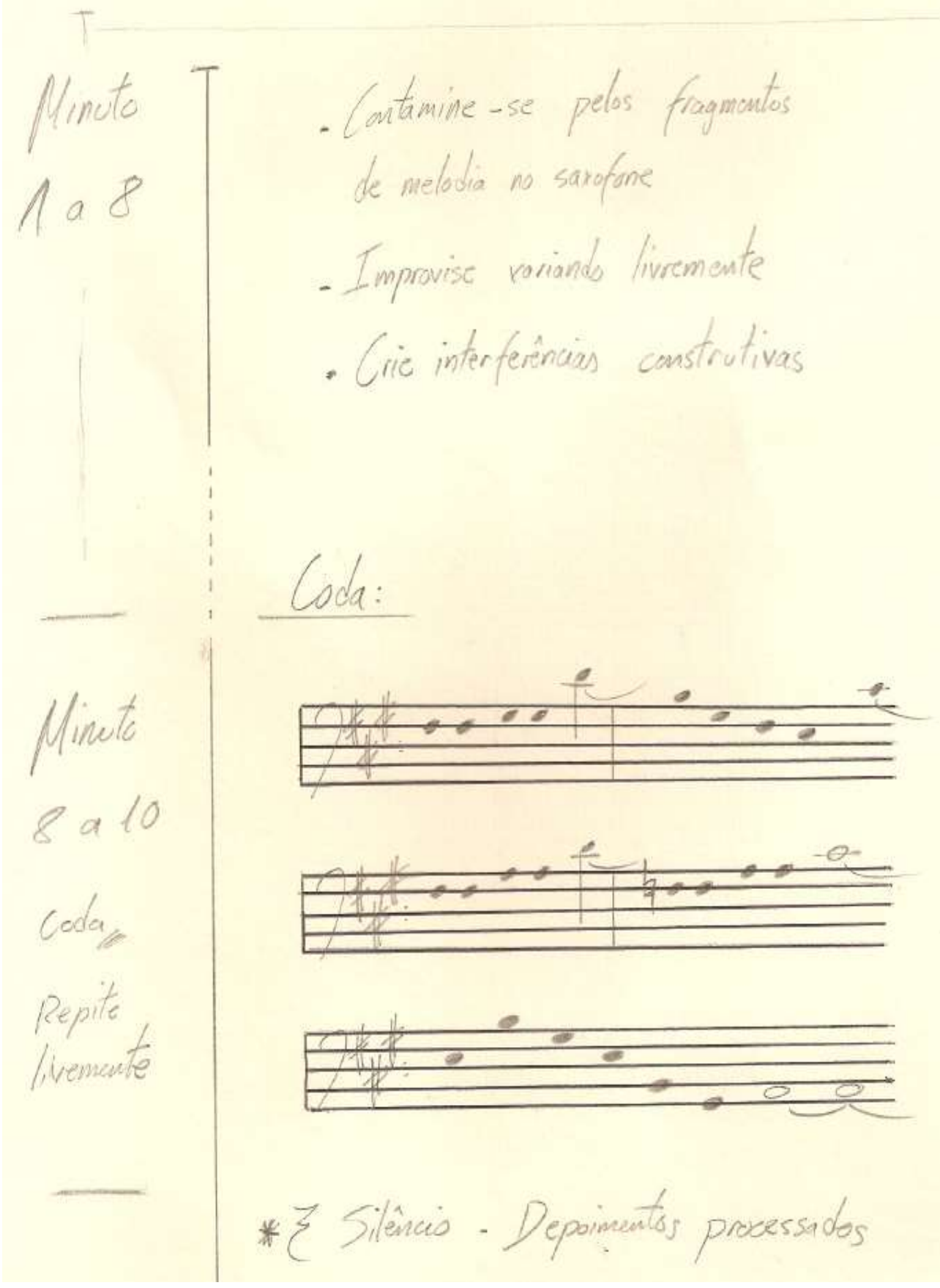

Figura 21. Partitura com as diretrizes para Fábio Martinelle (trombone baixo) 
Para os/as demais integrantes da Orquestra Errante, posicionados/as do lado de "fora" da grade, sugeri que improvisarem uma textura sonora da qual poderiam destacar-se brevemente citações dos padrões rítmicos da música paraguaia como: silencio de colcheia + duas colcheias e/ou duas semínimas pontuadas contra três semínimas. Neste caso optei por não escrever essas diretrizes em "partituras" ou mesmo indicar pessoas e instrumentos específicos. Essa opção atentava a uma característica comum na dinâmica do grupo, que nem todas as pessoas que participaram dos "ensaios" efetivamente participassem da performance - por isso achei melhor deixar essa parte da "orquestração" em aberto. No dia da performance, os/as músicos/musicistas da Orquestra Errante (além de Rogério Costa e Fábio Martinelle) que participaram foram: Ariane Stolfi (percussão), Fábio Manzione (bateria), Caio Righi, flauta transversal, Max Schenkman (luteria experimental), Luzilei Aliel (live electronics) e eu ao contrabaixo.

A improvisação musical acionada pelas referências sugeridas trabalhou simbolicamente a ruptura das grades que separam as pessoas, pois músicos/musicistas, cada um do seu "lado" da grade, acabaram se contaminando e interagindo apesar da separação, devido a pregnância de certos materiais como as configurações rítmicas, e a construção de estados provisórios a partir deles. Como exemplo, selecionei um áudio ${ }^{57}$ gravado durante um dos encontros da Orquestra Errante onde estudamos as diretrizes sugeridas (vide nota de rodapé). Esse encontro foi anterior aos "ensaios" de entrosamento junto com a KairosPania Cia. Cênico Sonora, por isso, o áudio não contém ainda os depoimentos. Cabe mencionar que no dia da performance não foi possível realizar um registro sonoro.

O nome da guarânia, "Lejania", remete a uma terra distante, de onde se sente saudades. Mesmo a tradução por "Meu primeiro amor" fala de algo que está perdido, de um sentimento que guarda uma certa pureza, inocência, e aponta para o desejo de retornar a algo que existe apenas como lembrança. Essas referências que a música aciona em

\footnotetext{
$57 \mathrm{O}$ áudio da gravação se encontra disponível em: https://soundcloud.com/interferencias sonoras/interferencias-sonoras-lejania-1-orquestra-errante
} 
nosso imaginário foram fundamentais para a criação da performance e decisivas para a sua escolha.

Na performance "Des a grad a vel", a música atua como meio possível de superação das barreiras mediante a interação sonora entre os/as participantes. Os depoimentos de lado de "fora" da grade revelam histórias de dor e dificuldade frente a migração forçada. Lembrando que mesmo que a grade física seja transposta, muitas outras grades e cancelas se impõem a vida de um migrante. Já do lado de "dentro", o que aparece é a indiferença perante essa questão, reforçando o muro real e simbólico que separa povos e culturas. Os depoimentos eram parcialmente sufocados pelas interferências sonoras de cada lado da grade. Nesse sentido, a performance não tem um caráter apaziguador, mas revela esteticamente a violência da situação.

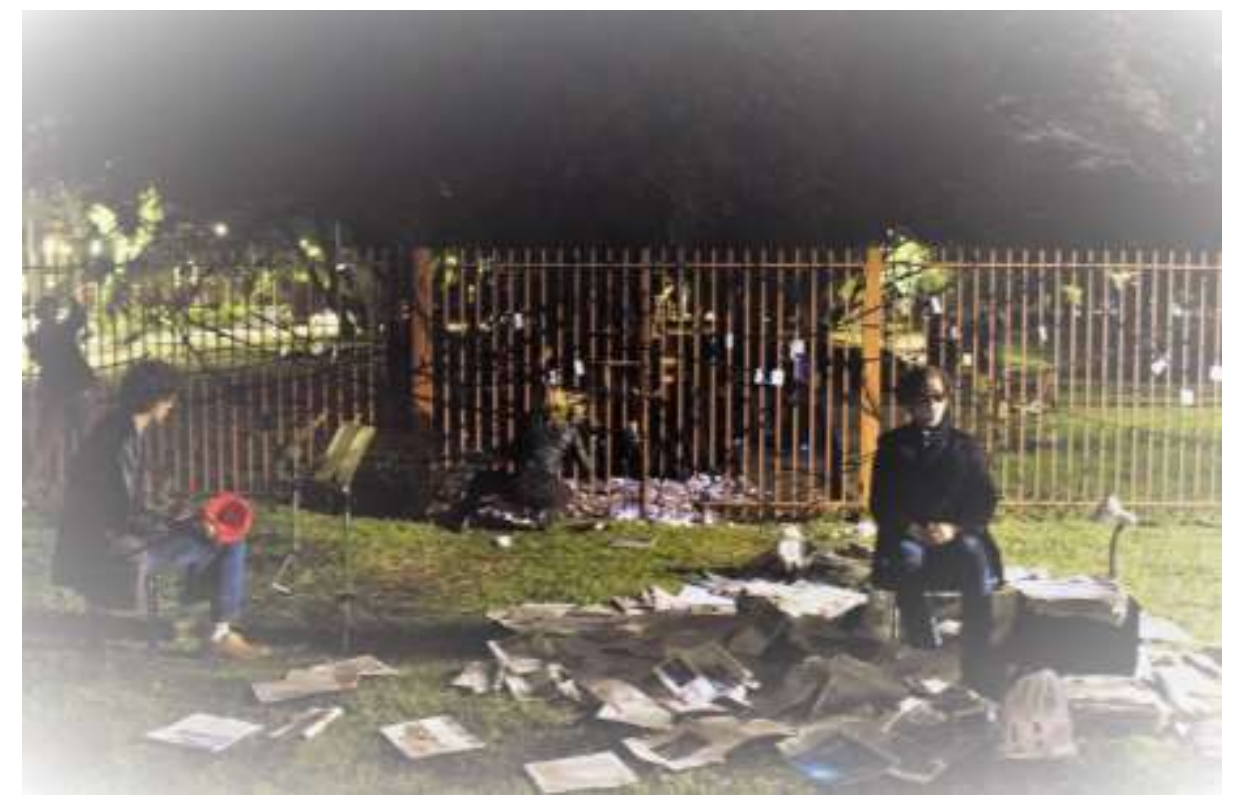

Figura 22. Performance "Des a grad a vel" KairosPania Cia. Cênico Sonora \& Orquestra Errante. Registro fotográfico de Pedro Paulo Kohler. Maio 2017.

A provocação acionada pelo ¿Música? em sua décima segunda edição, nos permitiu refletir a respeito do imenso trânsito de migrantes, refugiados e as péssimas políticas de acolhimento demonstradas pelos países - nos dedicar a pensar e reverberar essas questões nos impactou profundamente. Nos sentimos - e acredito que posso falar pelos integrantes da KairosPania Cia. Cênico Sonora e da Orquestra Errante -, chocados, 
tocados e impotentes ao ver homens, mulheres e crianças se lançando ao mar numa tentativa desesperada de sobrevivência e de busca por um futuro que não apenas o de esperar a morte.

O festival seguinte, ¿Música? \#13, foi organizado para o encerramento da Jornada de Música e Política do Instituto de Estudos Brasileiros da USP, em outubro de 2017. Dado que se tratava de discutir relações entre música e política, e do pouco tempo disponível entre um e outro trabalho, optamos por desenvolver outra performance sobre o mesmo tema. Revisitamos os materiais que levantamos na performance "Des a grad a vel" e criamos uma performance a partir deles.

\subsection{PERFORMANCE "A SÍRIA NÃO É AQUI”}

O evento ¿Música? \#13, organizado pelo NuSom, ocupou o Espaço das Artes (antigo Museu de Arte Contemporânea na USP). A performance "A Síria não é aqui" foi apresentada em um dos corredores entre as galerias do espaço.

A performance "A Síria não é aqui" 58 foi desenvolvida para ser executada a partir de um cubo de metal vazado de $2 \mathrm{~m}^{2}$. A performance não teve um caráter site specific como a primeira versão, porém estabelecemos que o perímetro do cubo nos ofereceria os motes dentro-fora, interno-externo, individual-social. A simples presença do cubo no espaço demarca essa relação, a materialidade de seus contornos ressalta isso. As grades foram substituídas pelas linhas do cubo, que demarcaram o lugar da performance.

Definimos com a KairosPania Cia. Cênico Sonora que o desejo e urgência de sair do cubo fariam alusão às experiências das pessoas que fogem da guerra. Mas a fronteira é uma barreira quase intransponível - afinal, mesmo quando ela for rompida, outras barreiras se apresentam. Então, não dava para tratar essa fronteira como algo invisível, imaginário. Ela precisava ser real. Por isso, nessa performance, optamos por envolver o

\footnotetext{
${ }^{58} \mathrm{O}$ teaser da performance está disponível em: https://www.youtube.com/watch?v=SeVRFgu15Vw
} 
cubo com um grande tecido elástico, de cor cinza. No tecido - convertido em parede e tela de projeção - projetamos imagens recolhidas de uma reportagem especial do jornal Folha de São Paulo que retratavam acontecimentos vividos nas fronteiras europeias, imagens que se transformavam, se somavam e se revezavam entre si, pilotadas por Luzilei Aliel por meio de processamentos de live electronics. Aliás, apenas Luzilei permaneceu do lado de fora do cubo. Mas tampouco podia ser visto pelo público. Ele ficou "escondido", operando o computador num quarto ao lado do corredor. Os/as demais participantes, tanto da KairosPania Cia. Cênico Sonora como da Orquestra Errante (numa versão reduzida em número de participantes, dado o espaço disponível), estávamos dentro do cubo. Assim, participaram da performance "A Síria não é aqui": Carmen Esteves, Kelly Caldas, Samya Enes, Yonara Dantas, Caio Righi (flauta transversal), Mariana Marinelli (saxofone tenor) e eu no violão.

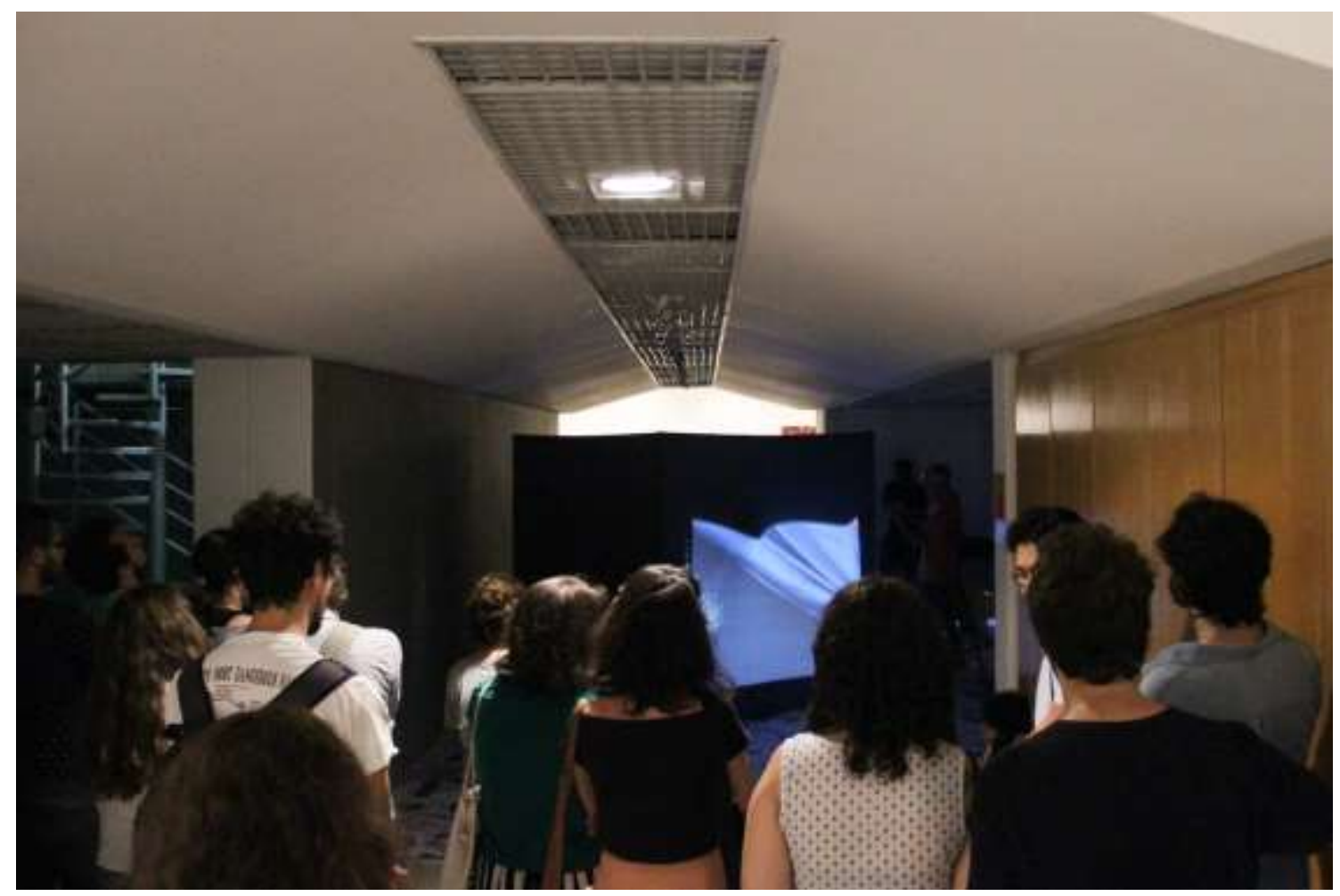

Figura 23. Performance "A Síria não é aqui". KairosPania Cia. Cênico Sonora \& Orquestra Errante. Registro de autoria indefinida. Outubro 2017.

Do lado de dentro, os corpos das performers Carmen Esteves, Kelly Caldas, Samya Enes e Yonara Dantas, imprimiam formas no tecido esticando-o para fora como se tentassem 
sair. Esses movimentos se configuravam como moldes pulsantes que deformavam as imagens projetadas na tela. A ideia era tratar os corpos como pulsão, como vida, lembrando a vida que pulsa por trás das imagens. Também de dentro do cubo emergia o som que explorava vestígios de uma canção suave (a guarânia Lejania), mas que não conseguia se desenvolver pois eram vestígios de lirismo, quase ininteligíveis. Essa textura sonora foi promovida pela exploração de fragmentos da guarânia Lejania que já tinham sido trabalhadas anteriormente (na performance "Des a grad a vel") com a Orquestra Errante. Corpos, imagens e sons atuaram juntos numa tripla perspectiva: exposição, deformação e pulsação.

Para a performance "A Síria não é aqui", não apresentei partituras gráficas ou propostas escritas, já que Caio Righi (flauta transversal) e Mariana Marinelli (saxofone tenor) conheciam a guarania Lejania pelo processo criativo da performance anterior. Desse modo, trabalhamos os fragmentos de melodias apenas a partir da memória e da livre interação.

Durante os encontros de preparação com os performers foram surgindo algumas direcionalidades, resultante das reflexões do coletivo. Estudamos quais gestos e movimentos desenvolvidos no contato dos corpos com o tecido conversavam ou contrastavam melhor com as imagens projetadas no tecido - ampliando suas possibilidades narrativas - bem como sincronizamos silêncios gestuais e sonoros "perto do fim" da performance e essas se tornaram diretrizes para a performance.

Do ponto de vista sonoro, Caio, Mariana e eu procuramos explorar a criação de alguns estados provisórios para esses gestos, além de conexões e interferências "mais livres" para os momentos de transição de imagens e movimentação das performers. 


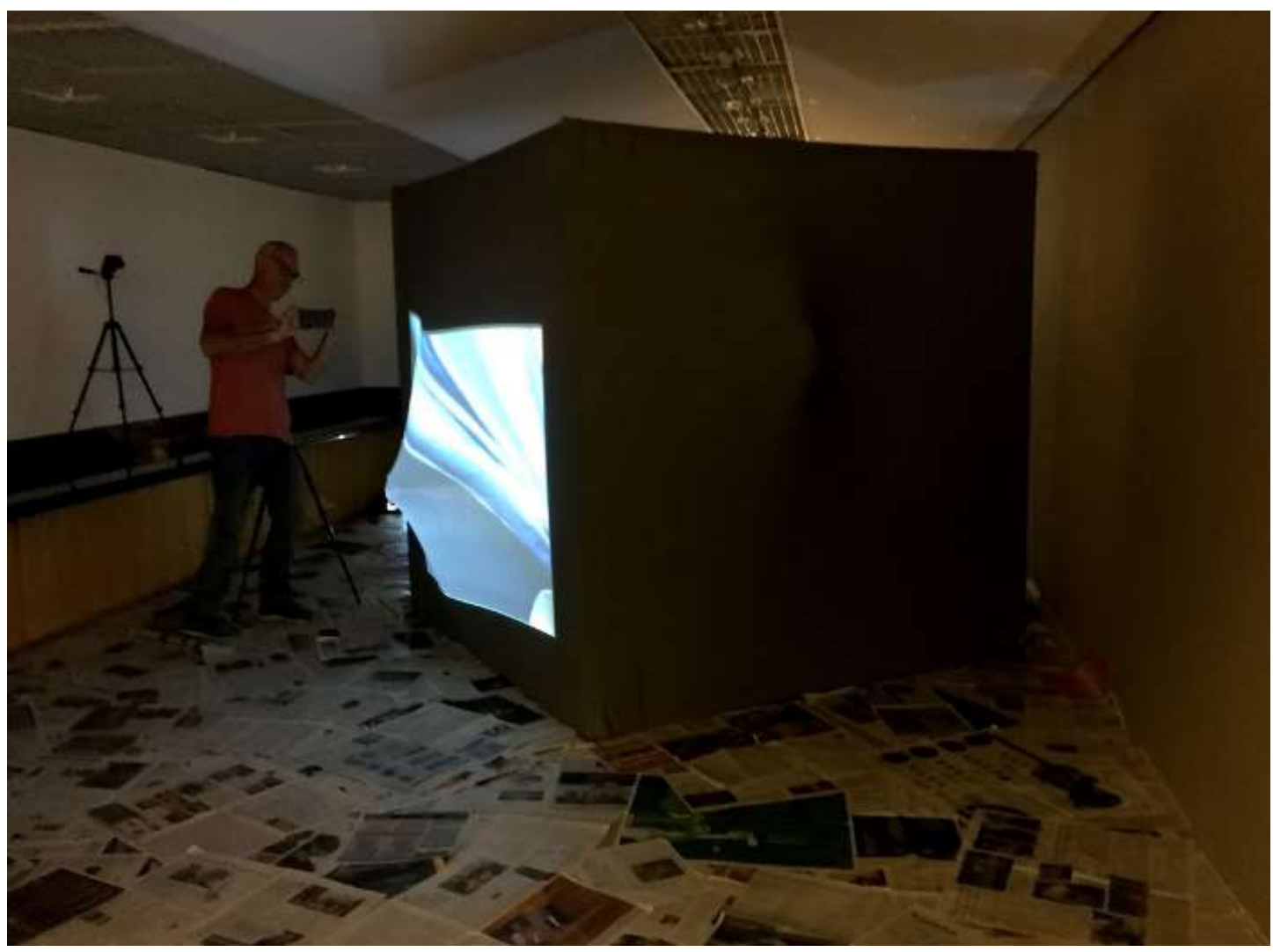

Figura 24. Performance "A Síria não é aqui". KairosPania Cia. Cênico Sonora \& Orquestra Errante. Registro de autoria indefinida. Outubro 2017.

Outro material revisitado da performance anterior foram os jornais. Desta vez eles surgiram cobrindo o chão ao redor do cubo. Reunimos várias edições de jornais e decidimos selecionar para que ficassem visíveis, dentre as notícias, aquelas que tratassem direta ou indiretamente sobre o tema dos refugiados, de modo que formassem um "tapete" de jornais no chão. Para nossa surpresa, diferente do que tínhamos observado nos jornais de maio daquele mesmo ano, haviam agora raríssimas reportagens que tratavam do tema. E não porque a crise tivesse cessado. Mas porque nada havia de novo sobre o assunto, que seguia, e ainda segue, sem horizontes de resolução. 


\subsection{PERFORMANCE "DELFINA"}

Diferente das performances apresentas acima, o processo de criação da performance Delfina iniciou sem relação a alguma chamada de festival ou concerto. Apresentei à KairosPania Cia. Cênico Sonora a polca paraguaia "Mateo Gamarra" onde se narra um trágico evento ocorrido no interior do Paraguay por volta de 1930, uma briga de um casal (Mateo e Delfina) que acaba no assassinato de Mateo por parte de Delfina. Essa polca é muito conhecida no Paraguay e vários grupos musicais gravaram suas versões ao longo dos anos.

A polca "Mateo Gamarra" pertence a uma categoria chamada compuesto, um tipo de canção paraguaia (com ritmo de polca) que se dedica ao registro de fatos verídicos. Os compuestos mais antigos que se tem referência datam da primeira década do século XX e são considerados um importante meio de transmissão de acontecimentos marcantes da sociedade. Para o pesquisador Florentín Gimenez (1997) o compuesto aparece como um modo de crônicas "depois da Guerra Grande ${ }^{59}$ [1864-1870], para suprir as necessidades de comunicação das cidades. Sua modalidade artística, exclusivamente de caráter narrativo, relata fatos que comoveram a população" (GIMENEZ, 1997, p.262 tradução minha $\left.{ }^{60}\right)$. Os compuestos são cantados nos diversos ritmos paraguaios como polca, guarânia e rasguido doble.

A KairosPania Cia. Cênico Sonora abraçou a ideia de desenvolver uma performance a partir do compuesto "Mateo Gamarra", e desde o início o grupo decidiu continuar utilizando o cubo de $2 \mathrm{~m}^{2}$ - o mesmo que foi utilizado na performance "A Síria não é aqui" -, sendo o único material "reciclado" para esta nova performance chamada "Delfina".

\footnotetext{
${ }^{59}$ A guerra dos aliados Brasil, Argentina e Uruguay contra Paraguay entre 1864-1870, também é nomeada como Guerra do Paraguay, Guerra Grande, Guerra Guazú e Guerra da Tríplice Aliança.

${ }^{60}$ No original: después de la Guerra Grande, para suplir a las necesidades de comunicación ciudadana. Su modalidad artística, que fue exclusivamente de carácter narrativo, relata aquellos hechos que conmovieron a la población (GIMENEZ, 1997, p.262).
} 
Da performance "Delfina” participaram Carmen Esteves, Samya Enes, Yonara Dantas, Natália Francischini, Fábio Manzione, André Teles e eu.

Para o processo criativo iniciamos pela audição da música e o estudo da letra do compuesto, por isso fiz a tradução do guarani para o português. A partir desse estudo, nos dedicamos a pensar com a KairosPania Cia. Cênico Sonora sua relevância no imaginário paraguaio, como ela revelava alguns mecanismos de construção identitária no Paraguay, bem como apontava diferenças entre Paraguay e Brasil, em especial no que se refere à figura feminina. $O$ estudo dos aspectos históricos e sociais presentes nessa música foram de tal sorte que resultaram na publicação do artigo "Apontamentos sobre narrativa oral, identidade, machismos e feminismos no compuesto Mateo Gamarra61" (2019), escrito por mim junto com Yonara Dantas. Embora nesse artigo não tenhamos abordado questões específicas do processo criativo da performance Delfina, os apontamentos que levantamos sem dúvidas subsidiaram o nosso processo criativo. Nos impressionava, dentre outras coisas, a qualidade do relato e a precisão de algumas informações como nome e sobrenome dos envolvidos, dia, hora e local do ocorrido, a força da figura feminina na narrativa, ao mesmo tempo em que a personagem masculina, mesmo em desvantagem, insiste em tomar a palavra e ser o protagonista.

Na performance, e com vistas a completar e alimentar nosso imaginário a respeito da história, identificamos alguns elementos na letra que nos permitiam depreender situações prévias a cena narrada, ligadas ao âmbito privado, como uma potencial situação de violência sofrida por Delfina por parte de Mateo. O desenlace dessa relação se dá o âmbito público, durante uma festa na qual Mateo desrespeita Delfina (o que imaginamos que devia acontecer no âmbito privado de forma cotidiana, aqui é explicitado). Ela, cansada com a situação, acaba matando-o com cinco tiros na frente de todos/as. Sob essa perspectiva, o cubo também funciona poeticamente como moldura que dá contorno a situação. Foi assim que utilizamos o cubo "vazio" sem as paredes de

\footnotetext{
${ }^{61} \mathrm{O}$ artigo completo se encontra no Anexo A do presente trabalho.
} 
tecido de modo que seus contornos delineassem os âmbitos privado (dentro do cubo) e público (fora do cubo) que inspiravam nossa leitura performática da canção.

O fato de ser um episódio ocorrido numa pequena cidade do interior e que ganhara perenidade e publicidade ao se tornar uma canção popular do país, diz da importância da canção como documento da memória coletiva.

Apresentamos a seguir a letra da música em seu idioma original e nossa tradução ao português: 


\section{Mateo Gamarra (versão original)}

I

Atención pido señores un momento pe hendumí la desgracia ha sucedido en el Puerto Guarani el 12 mes de octubre un baile ojeofrese omanó Mateo Gamarra en manos de su mujer

\section{II}

O je'oi la farra hápe pe pyhareve asaje rodando en este mundo para siempre en este día

el miércole desgraciado a las once del mediodía en la casa de Miguel Medina la desgracia osucede

III

"Oguahê upépe Gamarra una polca para mi"

onohê ombojeroky una tal Emilia Ortiz

sin recelo voi Gamarra Emilia-pe omongeta

ha héra la iserviha una tal Delfina Servín

IV

Upéicha ndaje Gamarra toda la pieza ojapo he'íma chupe Delfina "anivéna péicha reiko" "no hay caso", he'i Gamarra ha upéichante oseguí

"si es que ojedigustárõ che apoíntene ichugui".

V

Haupéva ohendu Delfina Gamarra pe osê he'i "ha nde nde gosaharâ quién sabe che karai, che ha'e Delfina Servín ne'îra chekuaapa, kuña jepe niko che, anicheva'erã che burlá"

VI

Osêma upépe Delfina con un revólver en la mano

los cinco tiros seguido Gamarrape ojapipa, ho'áma upépe Gamarra socorro ojerure,

"mba'ere piko Delfina rejapo kóicha che rehe"

VII

"Reikuaámapa Gamarra" ku Delfina oje'eha

"anichéne rejequeja si a tiempo ro avisa"

Gamarra no ñe'êvéima más que solo he'iva'ekue

"Adiós mante los amigos, pe vyaitékena che rehe".
Mateo Gamarra (tradução nossa)

I

Atenção peço senhores um momento pra ceis ouvir

a desgraça que aconteceu no Puerto Guarani no dia 12 de outubro um baile aconteceu lá morreu Mateo Gamarra pelas mãos de sua mulher

II

estavam indo pra farra que se ofereceu no meio da manhã

rodando neste mundo para sempre nesse dia a quarta-feira desgraçada às onze do meio-dia na casa de Miguel Medina a desgraça aconteceu

III

"Gamarra, aqui estou esperando uma polca para mim"

disse com vontade de dançar uma tal Emilia Ortiz

sem receio então Gamarra paquerou Emilia sendo que ele tinha uma patroa, uma tal Delfina Servín

IV

E desse jeito Gamarra continuou por toda a festa Delfina cobrou dele "para com isso"

"não tem jeito", disse Gamarra e então continuou

"se te incomoda, eu posso te deixar e pronto"

V

quando Delfina ouviu Gamarra, ela disse

"disfruta aí, quem sabe meu senhor,

eu sou Delfina Servín ainda não me conheces por completo

eu sou mulher, mas não por isso você vai zoar de mim"

VI

Então apareceu Delfina com um revólver na mão os cinco tiros seguidos em Gamarra atirou caindo então Gamarra socorro pedia “porque Delfina você fez isso comigo?"

VII

"você sabe bem, Gamarra" Delfina respondeu

"não venha se queixar se a tempo te avisei" Gamarra quase sem conseguir falar, só falou isso "adeus meus amigos divirtam-se bastante por mim". 


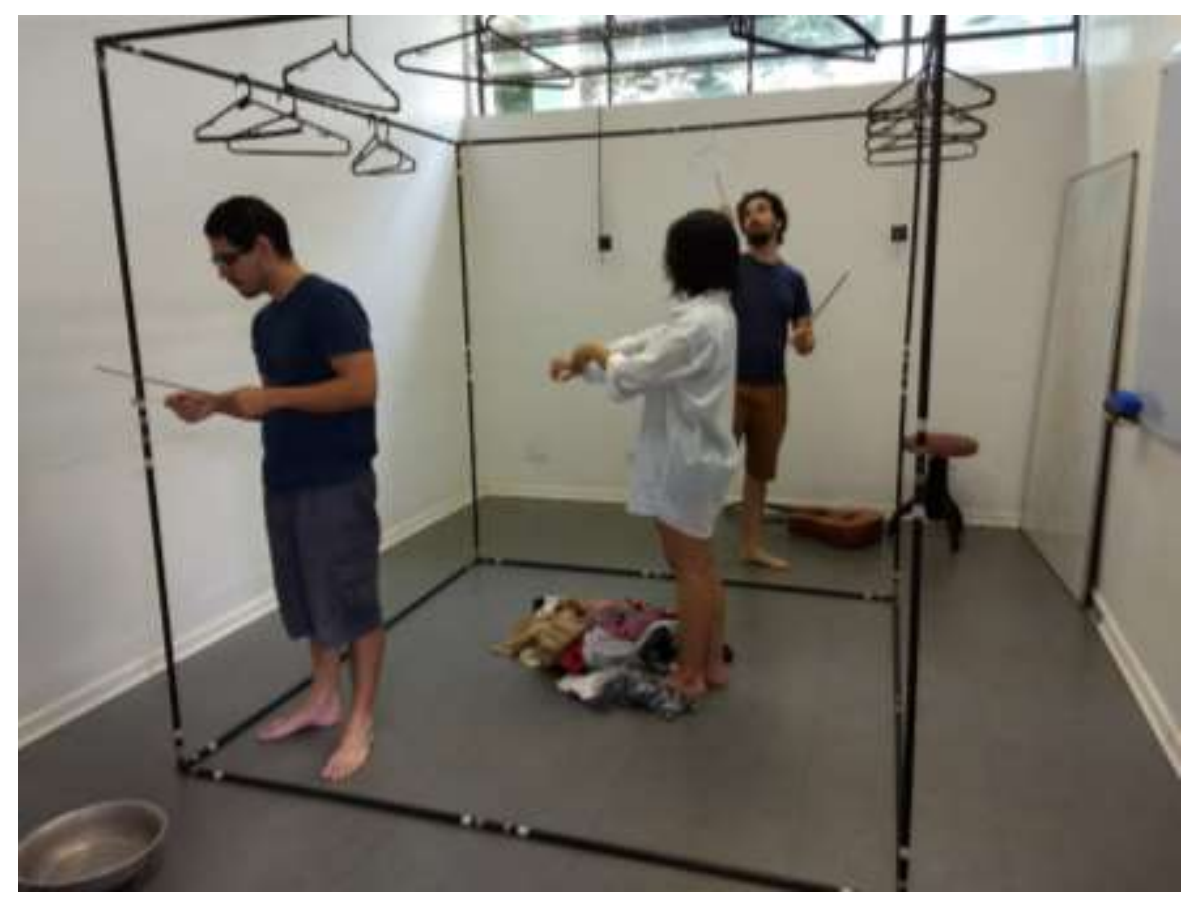

Figura 25. Primeiros encontros de preparação para performance "Delfina". Migue Antar, Samya Enes e Fabio Manzione. Registro Yonara Dantas. Maio 2018.

Além do estudo da letra do compuesto Mateo Gamarra, a história das personagens e o contexto socio histórico que a popularizou, outras referências também foram apresentadas e estudadas pela KairosPania Cia. Cênico Sonora durante os encontros de criação. Algumas delas inclusive sem aparente conexão com o universo retratado na letra, mas que se mostraram potentes na apresentação de ideias capazes de habitar nosso processo criativo.

Uma das primeiras referências acionadas pelo grupo foi o texto "Até que o dia os separe ou uma questão de luz" de Peter Handke. Nesse texto, a mulher citada por Krapp personagem da peça teatral "A última gravação do Krapp" de Samuel Beckett, responde ao personagem. Ela, que é citada an passant na peça original, chama a palavra e assume a narrativa.

Ainda para tratar do tema, buscamos músicas conhecidas no Brasil e que tratassem sobre crimes ou discussões passionais. Nesse sentido, escutamos e discutimos as músicas "Domingo no parque" (1968) de Gilberto Gil e "Maria da Vila Matilde" (2015), de Douglas Germano, gravada por Elza Soares - numa fusão impressionante da letra da música com a história de vida de sua intérprete, o que imprime força e contundência à 
interpretação. Já Domingo no Parque talvez seja a música sobre o tema mais conhecida no Brasil.

Outras duas referências que alimentaram o processo criativo "A última gravação do Krapp" de Samuel Beckett (também, mas não só, por sua relação com o texto de Handke) e a performance "2216 VHS Tapes ${ }^{62 "}$ de Lorenzo Durantini. Em ambos os trabalhos existe um olhar para fitas magnéticas de gravações, dispositivos que nos interessavam pois remetiam à ideia de que essas personagens que ficaram presas à essa história e a forma como elas foram contadas, como é o caso de Delfina e Mateo.

Cito essas referências pois, embora a principal seja o compuesto "Mateo Gamarra", elas foram complementares as pesquisas do grupo durante o processo de criação da performance "Delfina" e ampliaram as possibilidades estéticas e narrativas que a música nos oferecia. Tais referências nos ofereceram materiais para as explorações na sala de ensaio, propiciaram uma criação colaborativa e coletiva onde essas referências (algumas mais conhecidas que outras) colocadas em jogo com o material original nos permitiram depreender direcionalidades ao trabalho a partir das interferências desses materiais entre si, e na forma como cada participante os aportava no processo criativo.

Se trabalhamos com direcionalidade, se faz importante descrever o que entendemos com essa perspectiva. Para a pesquisadora Nitza Tenenblat (2015) é possível identificar enfoques metodológicos de criação a partir do peso que as proposições coletivas têm no processo de criação. Nesse sentido ela diferencia a "direção" da "direcionalidade", sendo esta última uma abordagem com maior grau de colaboração coletiva.

Isso significa dizer que além de um alto grau de propositividade entre os membros, há também muita flexibilidade. As escolhas são definidas apenas como consequência dos resultados das experimentações/explorações/diálogos entre criações e criadores (TENENBLAT, 2015, p.6).

O próprio material de referência não se apresentava como uma direção inequívoca para o processo criativo, mas como algo que nos revelava uma possibilidade. É nesse sentido

62 A performance "2216 VHS Tapes" de Lorenzo Durantini se encontra disponível no vimeo em: https://vimeo.com/66269376 (acesso janeiro 2021). 
que embora a referência principal para o processo de criação da performance "Delfina" fosse o compuesto "Mateo Gamarra", as referências complementares nos ofereceram materiais de exploração e "imagens de composição" que acrescentaram novos caminhos para a performance. Assim, alguns materiais acabaram sendo apresentados nos ensaios (o cubo, as fitas de vhs, a letra do compuesto, alguns possíveis figurinos etc.) e a partir de improvisações eles pudemos definir diretrizes para a performance. Nesse sentido, as escolhas das diretrizes não apontam a um planejamento no nível dos detalhes, no sentido de estabelecer dinâmicas ou durações. O foco do processo foi o planejamento composicional no nível macroscópico, procurando algo com um "grande arco" que conjugasse a nossa proposta, mas que a mantivesse aberta às interferências entre performers e materiais durante o devir da performance. Em outras palavras, 0 processo de preparação a partir de improvisações conjuntas foi fundamental para elaborar a estrutura comprovisatória por trás da performance "Delfina". Desse modo chegamos a um roteiro curto, com quatro momentos para a performance:

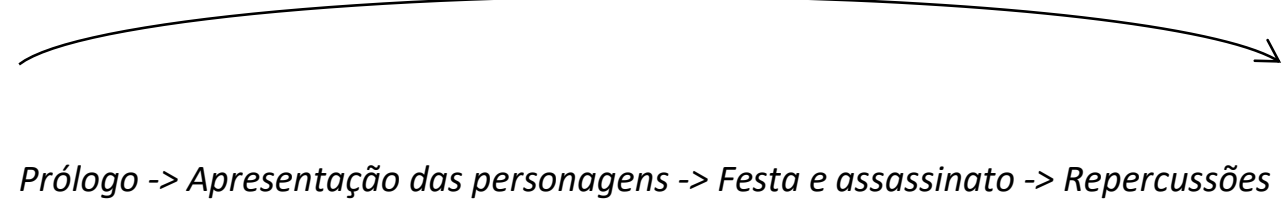

O tempo de duração, as dinâmicas e intensidades envolvidas, e a própria transição de uma parte para outra não estava determinada e dependia das relações ativadas no devir da performance. Como grupo procuramos nos aproximar de uma duração média de 30 minutos, porém dada a abertura e certa imprevisibilidade de sua própria estrutura composicional, as execuções da performance duraram entre 20 a 40 minutos.

No que se refere à parte "musical", destaco que realizamos sessões de escuta de diversas versões gravadas por grupos paraguaios do compuesto "Mateo Gamarra", e "contaminados" por esses materiais passamos a improvisar (Fábio Manzione e eu) com fragmentos da melodia. Essas improvisações não seguiam uma ordem linear de desenvolvimento e transformação, mas eram improvisações "livres" onde o fluxo 
sonoro era atravessado pela interferência dos fragmentos do compuesto "Mateo Gamarra".

Os sons produzidos durante a performance eram gravados e processados em tempo real por live electronics operado por André Teles. A captação dos sons ocorria mediante um microfone manipulado pela performer Carmen Esteves em cena. De maneira poética, ela caminhava pelo espaço com o microfone, procurando dar voz tanto aos materiais sonoros (instrumentos) como aos materiais que não tem voz (blusas, camisas, cabides etc.). Os sons eram gravados ao longo dos momentos "Apresentação das personagens" e "festa e assassinato", previstos no roteiro. Na parte "repercussões" tais gravações eram processadas e reproduzidas pelo live electronics, coincidindo cenicamente com um momento em que fitas VHS "inundavam" o cubo. Este ponto em específico buscava ecoar as diversas apropriações e versões da música original e da história de Mateo e Delfina, como detalhamos no artigo em anexo.

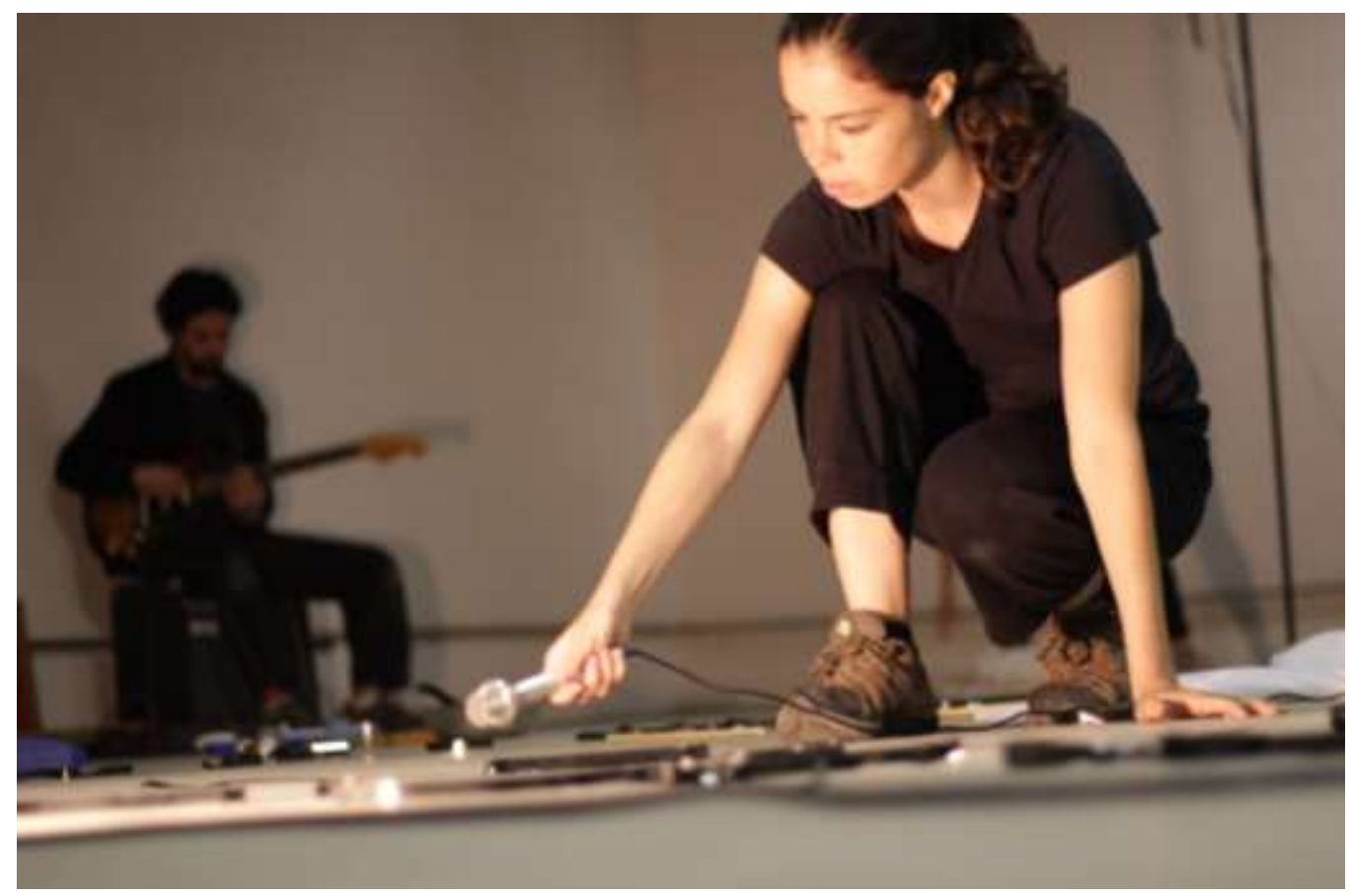

Figura 26. Carmen Estevez na performance "Delfina". KairosPania Cia. Cênico Sonora. Registro Itamar Dantas. Agosto 2018. 
A performer Natália Francichini propôs um trabalho de artes plásticas para a performance "Delfina". Ela traçava no chão com fita crepe retas e trilhos que seriam percorridos e investigados pelos/as demais performers (Carmen e Samya). E interferia na narração ao registrar em folhas de papel as palavras e expressões mais fortes da letra. Comentando o que estava sendo apresentado em cada momento, por vezes, como mulher e como performer, Natália, assumiu ainda a responsabilidade de dar fim à performance, desligando os amplificadores, as luzes, retirando os performers. Isso não era uma diretriz, mas por vezes foi acionado por ela.

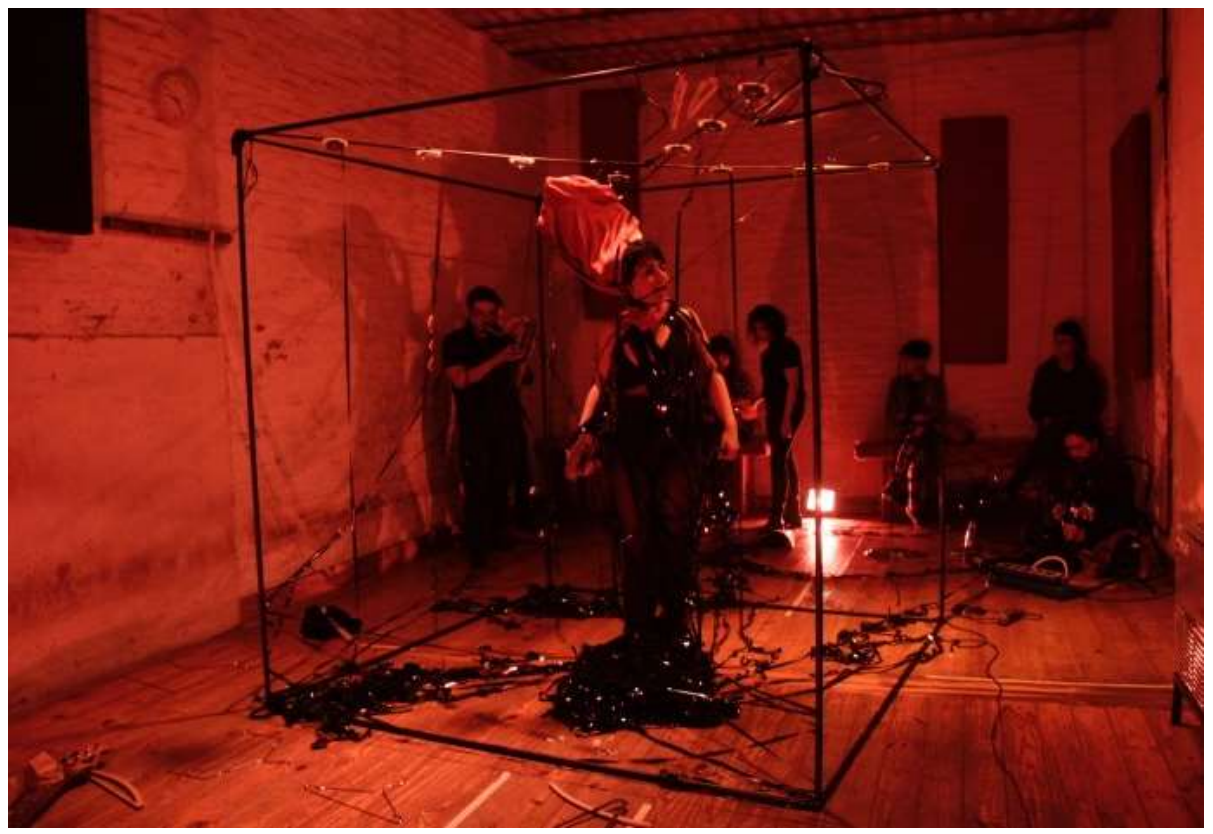

Figura 27. Performance "Delfina”. KairosPania Cia. Cênico Sonora. Casa Muñecas, Buenos Aires, Argentina. Registro Yonara Dantas. Setembro 2018.

Já a performer de dança contemporânea, Samya Enes, estava no centro da narrativa, apresentando e "vestindo" as personagens por meio das roupas em cabides penduradas no cubo. Por meio de sua dança, se apresentavam Mateo, Delfina e Emilia, as três personagens que protagonizam o trágico evento. Delfina vê Mateo tirando Emilia para dançar, pede que ele não o faça e ele a ignora, dizendo que se ela está insatisfeita, ela que se retire. Ela o adverte, mas ele não faz caso. Ela o assassina com cinco tiros em meio a festa. No fim, só resta ela, Delfina, pressa na sua história e nas lendas que dela surgem. 
A performance "Delfina" teve sua estreia em Buenos Aires, Argentina, apresentada no dia 13/09/2018 no Centro Cultural Zaguán Sur e no dia 14/09/2018 no Espaço Muñecas. Também foi apresentada em São Paulo no Espaço Redimunho como parte do Festival Satyrianas, numa data especial, dia 12/10/2018 (aniversário dos acontecimentos registrados na letra) e no dia 07/11/2018 no Departamento de Música da ECA USP, reunindo alunos/as das disciplinas de pós-graduação "A música como arcabouço da cena", do prof. Fabio Cintra, e "Os Territórios da Improvisação: Pensamento e Ação Musical em Tempo Real", do prof. Rogério Costa. 
Além dos exercícios realizados nos ensaios da Orquestra Errante e das performances desenvolvidas na parceria da Orquestra Errante com a KairosPania Cia. Cênico Sonora, trabalhos descritos anteriormente, apresento duas músicas que foram gravadas pela Orquestra Errante e que partiram de releituras de músicas paraguaias. A primeira, "Ndajekehai de mi suerte ambopúgui Orquestra Errántepe" compus como homenagem à orquestra para integrar o primeiro CD do grupo. A segunda, "Lucia Purahei" desenvolvi como uma proposta que pudesse envolver amigos do Paraguay e a Orquestra Errante.

\subsection{NDAJEKEHAI DE MI SUERTE AMBOPÚGUI ORQUESTRA ERRÁNTEPE}

Em 2019 a Orquestra Errante foi convidada para gravar um álbum musical que seria lançado no Selo Berro, recentemente inaugurado pelo NuSom. A gravação (que virou álbum duplo) ocorreu entre os meses de setembro e novembro de 2019 e o lançamento ocorreu em maio de 2020 de maneira virtual devido à pandemia do Corona vírus.

Após o convite de gravação pelo NuSom, a Orquestra Errante teve alguns encontros nos quais cada participante colocou suas ideias e juntos/as chegamos ao acordo de que iriamos gravar todas as propostas que surgissem, sendo que cada propositor/a se encarregaria de produzir e ajudar nas questões relativas à gravação e à mixagem de suas respectivas propostas. Organizamos uma agenda de modo a contemplar as propostas e 
realizamos as gravações toda quinta-feira no horário habitual dos encontros ${ }^{63}$ da Orquestra Errante.

Minha proposta para a Orquestra Errante partia de uma (re)composição da polca "Ndajekehai de mi suerte" do compositor paraguaio Odilio Román (1969-2019). O título em guarani significa "Não reclamo da minha sorte" e a letra trata da importância das amizades e companheirismo.

Odilio Román (1969-2019) - foi um representante do gênero polca paraguaia sendo autor de várias músicas de sucesso no passado recente, além de intérprete de músicas consagradas. Nasceu em setembro de 1969 na cidade de San Pedro del Paraná a 80 km de Encarnación - cidade fronteiriça do Paraguai com a Argentina - e a 306 km da capital Asunción. Com o grupo “Odilio Román y Los Románticos” obteve grande destaque no cenário musical do Paraguai, participando em diversos festivais folclóricos e fiestas patronales, muito comuns no interior do país. O grupo gravou 29 álbuns e realizou algumas turnês internacionais pela Europa.

O falecimento de Odilio em agosto de 2019, em consequência de uma doença hepática, foi muito sentido no país e obteve ampla cobertura dos meios de comunicação. Coincidentemente no dia de seu falecimento, domingo 4 de agosto de 2019, estávamos retornando de Asunción para São Paulo em uma viagem de carro - o que nos deu acesso a ouvir várias rádios paraguaias. Durante todo o caminho em território paraguaio ouvimos nas distintas rádios locais homenagens e dedicatórias ao artista acabara de partir. Também foram tocadas reiteradas vezes as músicas gravadas por Odilio e Los Románticos, entre elas, "Ndajekehai de mi suerte".

Na minha proposta de "releitura" para a música de Odilio Román, coloquei o título "Ndajekehai de mi suerte ambopúgui Orquestra Errántepe", que significa "Não reclamo da minha sorte porque eu toco na Orquestra Errante".

63 Um detalhe importante é que nossos encontros acontecem no estúdio de gravações do LAMI Laboratório de Acústica Musical e Informática, do Departamento de Música da USP, e por conta disso já tínhamos familiaridade com o espaço e o técnico de gravação Pedro Paulo Kohler. 
Escrevi a proposta em notação tradicional (partituras) para os seguintes instrumentos: voz, saxofone soprano, saxofone alto, viola, violão, trombone baixo, piano, baixo acústico e percussão. Na partitura se intercalam sessões "escritas", "sugestões" e também sessões "livres" nas quais se revezam algumas estratégias de interação já conhecidas pelas Orquestra Errante como: desenvolver improvisações a partir de diretrizes, investir no potencial dos materiais (ficar no problema), acreditar e entregarse no jogo (clownprovisar). Nesse sentido minha proposta foi uma homenagem à alegria dos encontros e uma expressão de gratidão por tantos momentos lindos e inopinados que tive a oportunidade de vivenciar nesse grupo. Participaram da gravação: Caio Righi, saxofone; Denis Abranches, luteria experimental; Fábio Manzione, bateria e percussão; Guilherme Beraldo, violão; Marina Mapurunga, voz, viola e violino; Migue Antar, contrabaixo; Paola Picherzky, violão; Rogério Costa, saxofone; Stênio Biazon, voz; Wilson Esteves, piano; e Yonara Dantas, voz.

Embora tenha escrito o "arranjo" em partitura, a estrutura a música alterna fragmentos da melodia original com momentos de Livre Improvisação cujas "proporções" (tempos, durações etc.) não estão determinadas pela pauta no papel. No dia da gravação, apresentei a proposta em partituras individuais para cada músico/musicista

Primeiramente apresentei à Orquestra Errante os trechos que contêm os fragmentos de melodias, para lermos juntos/as e tirar eventuais dúvidas. Depois passamos a explorar um pouco os jogos sugeridos para as sessões livres, que nada mais eram algumas sugestões o tipo: "textura sem pulso", "sensação de pulso", "loops e variações livres", "ficar no problema" etc. Após algumas "passagens" pelas partes, passamos a juntá-las todas. Assim, realizamos dois "testes" e a partir do terceiro começamos a gravar. Foram três takes, sendo que para o álbum escolhemos o terceiro deles. Na pós-produção do áudio não realizamos grande edições como cortes ou colagens, somente "mixamos" os volumes. Cabe ressaltar que a sala de gravações é uma só e todos/as estávamos juntos/as na mesma sala, o que influencia na relação espacial dos instrumentos no áudio final. 
O áudio ${ }^{64}$ da música "Ndajekehai de mi suerte, ambopúgui Orquestra Errántepe", assim como todas as demais faixas, se encontram disponíveis no Selo Berro na plataforma Bandcamp, e podem ser acessadas pelos seguintes links:

\section{https://berro-nusom.bandcamp.com/album/orquestra-errante-vol-1}

\section{https://berro-nusom.bandcamp.com/album/orquestra-errante-vol-2}

Na gravação se percebe a alternância entre os fragmentos da melodia original e duas grandes sessões de Livre Improvisação a partir dos procedimentos da Orquestra Errante.

De maneira resumida a estrutura resultante ficou assim:

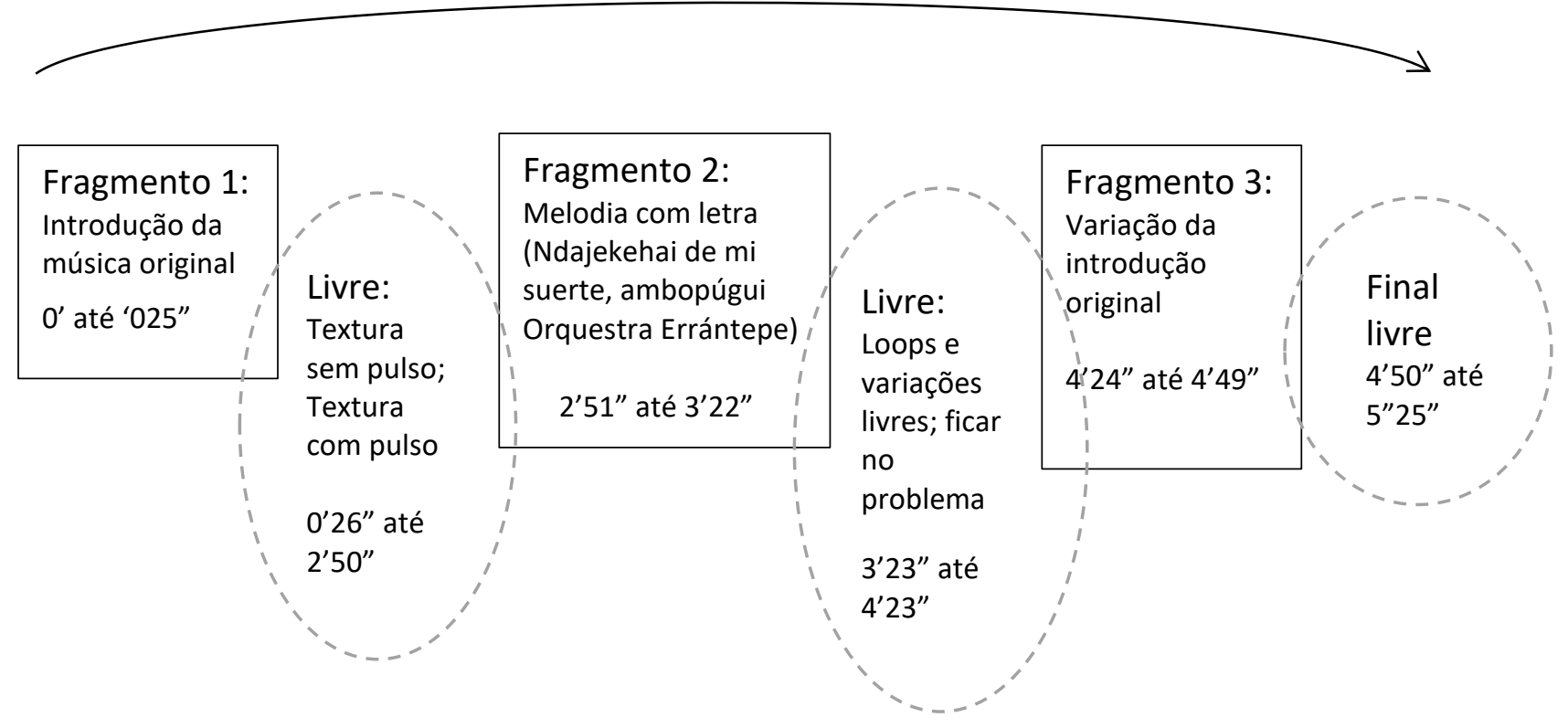

A grade da partitura completa se encontra no Apêndice B do presente trabalho.

${ }^{64}$ De maneira específica a música "Ndajekehai de mi suerte, ambopúgui Orquestra Errántepe" está disponível em: https://berro-nusom.bandcamp.com/track/nda-jekehai-de-mi-suerte-ambop-vaorquestra-err-ntepe 


\subsection{LUCIA PURAHEI (ORQUESTRA ERRANTE E AMIGOS DO PARAGUAY)}

A segunda gravação corresponde a música "Lucia Purahei", que em português significa "O canto de Lucia". Essa proposta surgiu como desdobramento de um estudo sobre a categoria "purahei jahe'o", um tipo de polca paraguaia característico das zonas rurais e do interior do Paraguay. A partir da análise de algumas polcas dessa categoria, Yonara Dantas e eu escrevemos o artigo "Desintegração de vozes, reintegração de posses: apontamentos sobre a polca purahei jahe'ó como narrativa de aspectos sócio-históricos da cultura paraguaia" (2020), que se encontra disponível no Anexo B do presente trabalho.

As reflexões levantadas no artigo eram o início de trabalho para uma possível nova performance, porém, com a chegada da pandemia do Corona vírus, nos vimos obrigados a reconfigurar o processo criativo. Nesse sentido, decidi realizar uma composição a partir de fragmentos das músicas acionadas no artigo: a polca "Chokokue Purahei" (canto do camponês), composta em 1937 por Francisco Alvarenga (1903-1957) e Mauricio Cardozo Ocampo (1907-1982); e o compuesto de Lucia Agüero sobre o Massacre de Curuguaty ${ }^{65}$ que se encontra no documentário ${ }^{66}$ "Fuera de Campo" (2014) dirigido por Hugo Giménez com produção de Tekoha Audiovisual para o IV DOCTV Latinoamérica. Esta última foi a referência principal da qual me inspirei para compor a música que foi gravada pela Orquestra Errante e amigos do Paraguay.

O relato de Lucia no seu compuesto descreve a violência com que os camponeses foram tratados pela polícia paraguaia, sem qualquer chance de defesa. E ressalta a forma como o Estado paraguaio tem tratado a questão fundiária sob a perspectiva camponesa. $\mathrm{Na}$ sétima estrofe, Lucia diz que "até aqui vou contar", e interrompe de súbito a música. É

\footnotetext{
65 No dia 15 de junho de 2012, um contingente de mais de 300 policiais e membros do Grupo de Operaciones Especiales (GEO), realizaram uma operação de reintegração de posse a favor da firma Campos Morombi, que resultou na morte de 17 pessoas (11 camponeses e 6 policiais). 0 trágico evento ficou conhecido como Massacre de Curuguaty.

66 O documentário "Fuera de Campo" (2014) se encontra disponível no vimeo em: https://vimeo.com/125523406 (acesso janeiro 2021).
} 
um choro que a faz interromper. Choro de revolta e de tristeza impresso naquilo que foi composto e também naquilo que sai espontaneamente na interpretação. E assim encontramos, Yonara e eu, a música como meio fundamental de registro de narrativas e de transmissão de histórias que seguem reivindicando melhores condições de vida das paraguaias e paraguaios camponeses, como indicamos no artigo (vide anexo).

A letra cantada ${ }^{67}$ por Lucia é a seguinte:

67 O compuesto cantado a cappella por Lucia Agüero, que relata o acontecido em Curuguaty, é apresentado no documentário Fuera de Campo (2014), no minuto 44, e se encontra disponível na internet com acesso livre na plataforma vimeo no seguinte link: https://vimeo.com/125523406 
Verso 1

Upépe ningo oikóma hete vece desalojo, policía mbaretépe umi carpero pe omoiama Upégui oñeformá entre setenta unido iderecho odefendemivo hasta omanovareaha

Verso 2

El vierne el 15 de junio, en el año 2012, osêjeima la orden desalojo oikohaguâ Carperokuéra ojeprepara ha oavisa policiápe: romanombáta ko'ape historia opytã haguã

Verso 3

A la siete de la mañana policía ja oallanáma Comisário Lovera oarteáma mâapa jefe oporandu Che ha'e he'i Pindu osêvo oimongetávo Avelino Espinola he'ipávo hesêma oñembokapu

Verso 4

Pastotýre isarambi odispara la pyaevéva ha umi itapykuéva yvatégui ojejapi Helikóterope oî policía con metralleta ha umi odisparaséva cobardemente ojejapi

$\underline{\text { Verso } 5}$

Ambulancia ogueroja policía muerto ha erido campesino katu erido pastotýre ojeehekuta Ule húme ojelelia oñemombo ojoári hopital Paraguaýpe pasillope inemba

Verso 6

Culpable ojehecha ha'eha parlamentário, senador há dipudado estáncia járape oladea Policia ojeignora há ojefelicita opytávo campesino sobreviviente imputado opytapa

Verso 7

Apevéntema amombe'u... (corte súbito)
Verso 1

Lá houveram vários atos de despejo os policiais com sua força os camponeses expulsaram Depois disso se uniram entre setenta pessoas para defender seus direitos até a morte

Verso 2

Na sexta-feira, 15 de junho, no ano 2012, Se emitiu uma nova ordem de despejo

Os camponeses se prepararam e deram aviso a polícia:

Aqui vamos morrer todos para que fique na história

\section{Verso 3}

As sete da manhã a polícia irrompeu no lugar o comissário Lovera perguntou quem era o chefe sou eu, respondeu Pindú, indo para conversar, apenas falou seu nome - Avelino Espínola - e começaram a atirar nele

\section{Verso 4}

Na pastagem se dispersaram, correndo os mais ágeis, já os atrasados, desde o alto atiravam neles No helicóptero estavam policiais com metralhadores os que tentaram correr, covardemente foram fuzilados

$\underline{\text { Verso } 5}$

A ambulância fazia o traslado de policiais mortos e feridos,

já os camponeses feridos foram executados na pastagem

Em sacos pretos foram colocados e amontoados um em cima do outro nos corredores do hospital de Assuncão,

os corpos já tinham cheiro

\section{$\underline{\text { Verso } 6}$}

Viu-se que os culpados foram os parlamentares, os senadores e deputados saíram em favor do dono da fazenda

A polícia saiu impune e foi felicitada,

os camponeses sobreviventes foram todos indiciados

Verso 7

Até aqui vou contar... (corte súbito)

Ambas as músicas (Chokokue Purahei e o compuesto de Lucia Agüero) revelam uma questão fundamental: a profundamente desigual distribuição de terra e de renda, realidade tanto no Brasil como no Paraguay. Partindo desse imaginário em comum, escolhi desenvolver um processo de criação que aliasse artistas de ambos os países. 
Da polca Chokokue Purahei ${ }^{68}$ selecionei a parte da introdução e inspirado nela, elaborei a introdução e a "levada" da proposta "Lucia Purahei" para a Orquestra Errante. Do compuesto de Lucia Agüero, retirei a melodia que ela canta ( $d o, l a$, sol, descendentes) e também atentei para o número de vezes que Lucia repete os versos, que são seis. No início do sétimo verso, ela interrompe o relato abruptamente. Na proposta que compus se revezam a "levada" que ecoa a primeira referência com os "versos" da segunda, sendo que a música acaba como o canto de Lucia, de maneira abrupta, no início do que seria o sétimo verso.

Devido às restrições por conta da pandemia do Corona vírus, o processo de gravação foi realizado à distância, cada músico gravando em sua casa. Nesse sentido, organizei a sequência de gravações da seguinte maneira: Primeiro gravei o contrabaixo e mixei uma faixa de áudio com alguns sons midi correspondentes às partes escritas dos instrumentos de sopro. Essa faixa de áudio serviu como guia para os bateristas Sebastian Ramirez (de Paraguay) e Fábio Manzione (de Brasil).

Uma vez que cada um gravou e me enviou sua parte, realizei uma nova mixagem com baterias e o contrabaixo. Essa nova faixa foi a guia para que David Rodriguez (de Paraguay) gravasse o saxofone alto e Ronalde Monezzi (de Brasil) gravasse o saxofone tenor e a flauta transversal. Uma vez que eles me enviaram as suas gravações, realizei uma nova mixagem e esta última enviei para o Prof. Rogério Costa (de Brasil) que gravou por último o saxofone soprano.

A faixa de áudio final se encontra disponível em:

https://soundcloud.com/interferencias sonoras/lucia-purahei-orquestra-errante-e-amigos-deparaguay

A grade da partitura completa se encontra no Apêndice $C$ do presente trabalho.

68 Tomei como referência a gravação de 1973, do grupo paraguaio Vocal Dos, disponível no youtube em: https://www.youtube.com/watch?v=mMZO9xe6kck (acesso janeiro 2021). 
Esta pesquisa me permitiu aproximar música paraguaia e procedimentos de Livre Improvisação. Nesse sentido, a presente tese é como um desdobramento de uma investigação iniciada ainda como aluno da graduação em Música - a cada etapa (TCC, mestrado e agora, no doutorado) eu pude desdobrar um aspecto da Livre Improvisação e, com isso, pude ir me aprofundando nas suas possibilidades expressivas, ampliando e desenvolvendo meu repertório teórico e prático como músico. As experiências junto com a Orquestra Errante e o trabalho do Prof. Rogério Costa transformaram minhas ideias sobre música, me permitindo acessar ferramentas de pesquisa e criação fundamentais em minha trajetória por meio de exercícios e criações que se ancoram na interação, escuta, colaboração e companheirismos. Se é pelo mergulho na particularidade que o todo se revela, espero que a presente tese, bem como as experiências e criações aqui sistematizadas, possam servir de fonte de pesquisa e inspiração para outros/as pesquisadores/as, a partir de suas histórias pessoais e ganchos possíveis com essa vasta e complexa área de criação artística que é a Livre Improvisação.

Afinal, é fundamentalmente de liberdade que se trata essa prática. A liberdade de transitar pelos diversos territórios musicais que nos influenciam de alguma maneira e, também a procura por fugir deles, explorar novos lugares, e com isso nos permitir, de forma individual e coletiva, abraçar ideias de jogo e criação. A perspectiva que acionei como chave de acesso para esses encontros de universos musicais, o conceito de interferências, é um dentre tantos possíveis. É a porta ou janela - ou melhor, lente - que utilizei e que se mostrou mais promissora para me permitir visualizar o encontro e confronto de referências com os procedimentos experimentais da Orquestra Errante. 
Isso significa que ocorreu uma diluição das referências paraguaias? Em parte, sim: no sentido sonoro, em especial na perspectiva das "tópicas" (Piedade 2013). Os elementos musicais desterritorializados perderam sua conexão com o idioma e, portanto, deixaram de funcionar como "tópicas". Em parte, não: porque no processo criativo das performances outras referências não somente musicais - por exemplo: o contexto histórico, suas lutas simbólicas, a análise das personagens e situações apresentadas nas letras das canções etc. -, também foram estudadas e levadas em consideração. Essas referências funcionaram como "referentes" (COSTA, 2016) para a improvisação e, nesse sentido, se mantiveram presentes e pulsantes.

No que se refere aos procedimentos musicais, as experiências realizadas com a Orquestra Errante - tanto os exercícios citados no capítulo dois, como as músicas que chegaram à etapa de gravação e apresentadas no capítulo quatro - exigiram um duplo movimento, meu e dos/as demais integrantes do grupo. De minha parte, exigiu escuta dos materiais originários buscando neles aquilo que para um cidadão e músico paraguaio é óbvio, mas que precisava ser nomeado, sistematizado e organizado para ser apresentado a músicos e musicistas não fluentes em suas especificidades. $E$, nisso que me parecia óbvio, haviam nuances que eu mesmo precisava desvendar. Talvez, como analogia, tenha sido como passear a pé por um caminho que sempre se percorre de carro. A paisagem é conhecida, mas a pé é possível ver e se dedicar a coisas que, de carro, se conhece apenas an passant. Por parte dos/as demais integrantes do grupo, exigiu uma escuta atenta e dedicada, que saísse da zona de conforto de estereótipos e de referências por vezes afetivas e mnemônicas advindas do parentesco da música paraguaia com uma linhagem da música "caipira" brasileira. Essa memória coletiva foi importante, no entanto, não podíamos perder de vista que era de música paraguaia que se tratava, o que é parecido não é igual.

Creio que esses exercícios exigiram de todos nós um movimento em direção ao outro, aprofundaram relações afetivas e musicais. E essa é outra das características que formam - e forjam - a Orquestra Errante. Cada músico ou musicista, ao improvisar com o coletivo, ao se colocar em jogo, leva consigo sua biografia e a imprime nesse coletivo. Sem dúvidas, a Orquestra Errante é o que é devido ao encontro e, por que não, às interferências que seus integrantes conferem à linguagem e à identidade artística desse 
coletivo. Encontros que se dão de forma pacífica e dialogada, bem como os encontros marcados por dissensos e confrontos.

A presente pesquisa me fez aprofundar ainda um outro olhar iniciado no mestrado - a aproximação da Livre Improvisação com o corpo e a narratividade advindas da Dança e do Teatro e apresentada no capítulo três da presente tese. A presença do corpo, do movimento, de imagens e materiais, e de um jogo cênico inspirado por narrativas impressas nas letras e histórias das músicas pesquisadas, fez com que essas músicas colocadas em interferência revelassem camadas discursivas que apenas sua audição talvez não fosse capaz de revelar.

Em síntese, as iniciativas desenvolvidas exigiram um papel ativo e criativo por parte dos/as músicos/musicistas a partir de uma perspectiva de ação experimental e colaborativa, promovendo alternativas de expressão, inclusive em repertórios consolidados no folclore e tradição. Somou-se a isso o caráter interdisciplinar de trabalho da KairosPania Cia. Cênico Sonora que alia dança, artes cênicas, artes plásticas à música da Orquestra Errante, sistematizando um modo de criação profundamente afeito à perspectiva da comprovisação.

Depreende-se do presente trabalho uma potente perspectiva de interferência entre processos de improvisação e referências paraguaias. Espero eu, capaz de apontar caminhos criativos para outros/as artistas da música, bem como revelando a força e qualidade da música e cultura paraguaias. 
ALIEL, L.; COSTA, R.; KELLER, D. Comprovisação; Abordagens desde a Heurística Estética em Ecocomposição In: 15o. Simpósio Brasileiro de Computação Musical - SBCM, 2015, v.1. p.169 - 180. Campinas: Editora da universidade de Campinas, 2015.

ALONSO, Chefa. Improvisación Libre: la composición en movimiento. Baiona: Editora Dos Acordes, 2008.

BAILEY, Derek. Improvisation: its nature and pratice in music. British Library National Sound Archive, 1993.

BHAGWATI, Sandeep (2013). Notational Perspective and Comprovisation. In: ASSIS, W.; COESSENS, K.. Sound \& Score: Essays on Sound, Score and Notation: 165-177. Leuven: Orpheus Institute Press. 2013.

BOETTNER, Juan Max. Música y Músicos del Paraguay. Asunción: Edición de autores paraguayos asociados, 2011.

BORGO, David. Negotiating Freedom: values and practices in Contemporary Improvised Music. In: Black Music Research Journal, vol.22, n², p.165-188, Columbia College Chicago and University of Illinois Press, 2002.

BRAUN, Luci F. Motter; BRAUN, Thomas. A montagem de Young no estudo da interferência, difração e coerência de fontes luminosas. Instituto de Física UFRGS. Cad.Cat.Ens.Fis., v.11, n³, p.184-195, dez., 1994.

CAMPESATO, Lilian; IAZZETTA, Fernando. Práticas locais, discursos universalizantes: relendo a música experimental. In: Desobediência Sonora: Selos de Música Experimental e suas Tecnologias de Sustentabilidade. Org. Cristiano Figueiró, p.7-42. Salvador, 2019.

COBUSSEN, Marcel. The Field of Musical Improvisation. Leiden: Leiden University Press.

COHEN, Renato. Performance como linguagem. Perspectiva, São Paulo, 2013.

COSTA, R.; SCHAUB, S. Expanding the concepts of knowledge base and reference. In: Anais do XXIII Congresso da Associação Nacional de Pesquisa e Pós-Graduação em Música, UFRN, p. 1-9. Natal-RN, 2013. 
COSTA, Rogerio. 0 músico enquanto meio e os territórios da Livre Improvisação. Tese (Doutorado em comunicação e semiótica) Programa de Pós-Graduação da Pontifícia Universidade Católica de São Paulo, São Paulo, 2003.

. Livre Improvisação e pensamento musical em ação: novas perspectivas. In. FERRAZ, Silvio. Notas Atos Gestos. p. 143-178. Rio de Janeiro, 2007.

. A livre improvisação e a filosofia de Gilles Deleuze. Revista Per Musi (UFMG), v.26, p.60-66, 2012.

Na Orquestra Errante ninguém deve nada a ninguém. Revista Música Hodie, vol 13, n¹, Goiânia, 2013a.

A livre improvisação musical enquanto operação de individuação. Artefilosofia (UFOP), v. 15, p. 34-45, Ouro Preto, MG, 2013 b.

. Música Errante: o jogo da improvisação livre. Editora Perspectiva, FAPESP, São Paulo, 2016.

. Transversalidades: música e políticas. In: Música, transversalidade. Org. Felipe Amorim, José Antônio Baêta Zille. EdUEMG, Belo Horizonte, 2017.

A improvisação livre não é lugar de práticas interpretativas. Revista Debates, v.20, n¹, Editora da Unirio, Rio de Janeiro, 2018.

. Orquestra Errante: uma prática musical entranhada na vida. Revista Música, $v^{\circ} 20$, p.309-328, (online), 2020.

CREYDT, Oscar. Formación Histórica de la Nación Paraguaya. ServiLibro, Asunción, 2010.

DOMINGUEZ, Célia Ruiz de. Danzas tradicionales del Paraguay. Teleeducación, FONDEC, Asunción, 2005. Link de acesso: https://www.youtube.com/watch?v=0q4DOAV2eHE\&t=716s (último acesso em janeiro 2021)

ELIAS, R. La investigación musical en Paraguay: una reseña. Online: http://docplayer.es/15312930-La-investigacion-musical-en-paraguay-una-resena.html (último acesso dezembro 2018).

FALLEIROS, Manuel. Palavras sem discurso: Estratégias criativas na Livre Improvisação. Tese (Doutorado em Artes) - Programa de Pós-Graduação em Música da Escola de Comunicações e Artes da Universidade de São Paulo, São Paulo, 2012.

A Livre Improvisação no contexto pós-moderno: indícios de uma "Hiperimprovisação". In: Anais do XXIII Congresso da Associação Nacional de Pesquisa e Pós-Graduação em Música, UFRN. Natal-RN, 2013.

Roteiros, Propostas e Estratégias: por uma poética mosaica da Improvisação Livre. Revista Debates, n²0, p.188-208, mai. 2018 
FARACO, Arthur; FALLEIROS, Manuel. Mystery and Manners: comprovisação, localidade e cosmopolitismo. In: Anais do XXIX Congresso da Associação Nacional de Pesquisa e Pós-Graduação em Música ANPPOM, UFPel, Pelotas, RS, 2019.

FERRAZ, Silvio. Apontamentos realizados durante as aulas da disciplina: A noção de Imagem de Composição, oferecida no Departamento de Música da USP no $1^{\circ}$ semestre de 2018.

GIMENEZ, Herminio. La música paraguaya. Editorial El lector, Paraguay, 1997.

GIMENEZ, Hugo. Fuera de Campo. Documental de Tekoha Audiovisual para el IV DOCTV Latinoamérica, 2014. Disponível no link: https://vimeo.com/125523406 (último acesso em janeiro 2021).

GONZALEZ, E.; DUARTE, G. Música e músicos na Tríplice Fronteira (Brasil, Argentina, Paraguai). Revista Tempo da Ciência, vol.20, n³9, p. 39-60, 2013.

GONZALEZ, Emilio. Entre Rios, Sonoridades e Memórias: a construção de identidade(s) culturais a partir de diálogos musicais na Tríplice Fronteira Brasil / Paraguai / Argentina. Anais do VI Congresso Internacional de História. Universidade Estadual de Maringá. Maringá, 2015.

HASEMAN, Brad. A Manifesto for Performative Research. Media International Australia incorporating Culture and Policy, theme issue "Practice-led Research" n 118, p.98-106, 2006.

HIGA, Evandro. Os gêneros musicais Polca Paraguaia, Guarânia e Chamamé: formas de ocorrência em Campo Grande Mato Grosso do Sul. Dissertação (Mestrado em musicologia) Programa de Pós-Graduação da Universidade de São Paulo, São Paulo, 2005.

Polca paraguaia, guarânia e chamamé: estudos sobre três gêneros musicais em Campo Grande-MS. Editora UFMS, Campo Grande, 2010.

Para fazer chorar as pedras: o gênero musical guarânia no Brasil. Tese (Doutorado em música) Programa de Pós-Graduação da Universidade Estadual Paulista Júlio de Mesquita Filho, São Paulo, 2013.

A assimilação dos gêneros polca paraguaia, guarânia e chamamé no Brasil e suas transformações estruturais. In: VII Congresso IASPM Rama Latino-americana, Havana, Cuba, 2006.

HORST, René Harder. El Régimen de Stroessner y la Resistencia Indígena. CEADUC Centro de Estudios Antropológicos de la Universidad Católica "Nuestra Señora de la Asunción". Asunción, 2007.

IAZZETTA, Fernando. Música e Mediação Tecnológica. Perspectiva: FAPESP, 2009. 
Técnica como meio, processo como fim. In: Teoria, crítica e música na atualidade. Org. Maria Alice Volpe. Série Simpósio Internacional de Musicologia da UFRJ. Universidade de Rio de Janeiro, 2012.

. Palestra inaugural, série Estudos do Som. Centro de Formação e Pesquisa do SESC, São Paulo, 2015.

Entre a pesquisa e a criação: a experiência dentro da sonologia. In: Anais do XXIV Congresso da Associação Nacional de Pesquisa e Pós-Graduação em Música, Unesp, p. 1-9. São Paulo, 2014.

- La música es mucho más (o menos) que la música: reflexiones sobre investigación musical en el contexto de la academia. In: Creación musical, investigación y producción académica: Desafíos para la música en la universidad. Daniel Quaranta (coordinador). CMMAS - Centro Mexicano para la Música y las Artes Sonoras. Casa de la Cultura. México, 2017.

IAZZETTA, Fernando; CAMPESATO, Lilian. La serie ¿Música? Arte sonoro desde contextos locales. I Simposio Internacional de Arte Sonoro: Mundos Sonoros: cruces, circulaciones, experiencias. p.143-152, UNTREF. Buenos Aires, Argentina. 2019.

IAZZETTA, Fernando; CAMPESATO, Lilian. La serie ¿Música? - arte sonoro desde contexto locales. In: Sulponticello - Revista online de música y arte sonoro. 1 julio 2020 (online). Link para acesso: https://sulponticello.com/iii-epoca/la-serie-musica-artesonoro-desde-contextos-locales/ (acceso en diciembre de 2020).

Notas sobre a guarânia Lejania: http://www.abc.com.py/espectaculos/red-globopresenta-musica-paraguaya-como-brasilena-45941.html

https://www.ultimahora.com/brasilenos-se-apropian-la-guarania-lejanian278790.html https://www.ultimahora.com/embajada-paraguaya-brasil-exige-rectificacionguarania-n279924.html;

https://noticias.uol.com.br/ultnot/internacional/2009/12/04/ult1859u1996.jhtm; https://www.ultimahora.com/red-globo-rectifica-y-reconoce-autoria-paraguayalejania-n280689.html; http://www.abc.com.py/articulos/globo-corrige-el-error-sobreguarania-lejania-48103.html

OLIVERA, Rubén. El concepto de identidad y el espacio sonoro en América Latina. In: La Música en Paraguay: situación actual y perspectivas de futuro - Ponencias presentadas en el $1^{\circ}$ Simposio de la Música en Paraguay. Asunción, Paraguay, 2019.

PENNER, H.; ACOSTA S.; SEGOVIA M., El descubrimiento del castellano paraguayo a través del guaraní: una historia de los enfoques lingüísticos. Centro de Estudios Antropológicos de la Universidad Católica Nuestra Señora de la Asunción - CEADUC. Paraguay, 2012.

PEREIRA, Arturo. Origen Social de la Música Popular Paraguaya. Fondec, Asunción, 2011. 
PIEDADE, Acácio. Perseguindo fios da meada: pensamentos sobre hibridismo, musicalidade e tópicas. Revista Per Musi, n²3, p.103.112, 2011.

A teoria das tópicas e a musicalidade brasileira: reflexões sobre a retoricidade na música. In: Revista El Oído Pensante, vol.1, n²1, 2013.

RIVEROS, Justiniano. La polca "Mateo Gamarra", una historia verídica que cumplió 86 años. In: Última hora. 13 de out. 2017. Disponível em: < https://www.ultimahora.com/lapolca-mateo-gamarra-una-historia-veridica-que-cumplio-86-anos-n1112958.html>.

(último acesso dezembro 2020).

SZARAN, Luis. Diccionario de la música en el Paraguay. Asunción: Société Générale de Surveillance, 1999.

TENENBLAT, Nitza. Direção e Direcionalidade na criação em coletivo. Revista do LUME - Núcleo Interdisciplinar de Pesquisas Teatrais - n²7, agosto - UNICAMP, 2015.

TOFFOLI, Dainara. Dona Helena. M. Schmiedt Produções. Documentário. 2004. Disponível em: https://www.youtube.com/watch?v=nTGOLwoOYa0

TOUSSAINT, Godfried. The geometry of musical rhythm. CRC Press Taylor \& Francis Group, 2013.

ZAMBONI, Silvio. A pesquisa em Artes: um paralelo entre arte e ciência. Editora Autores Associados. Campinas SP. 1998.

ZAMBONI, Silvio. A pesquisa em Artes: um paralelo entre arte e ciência. Editora Autores Associados. Campinas SP. 1998.

ZUMTHOR, Paul. Performance, recepção, leitura. Cosac Naify, São Paulo, 2014. 
APÊNDICE A. GRADE DO ARRANJO DE ACHUITA PARA A ORQUESTRA ERRANTE 


\section{Achuita}

Motivo Popular

Orquestra Errante
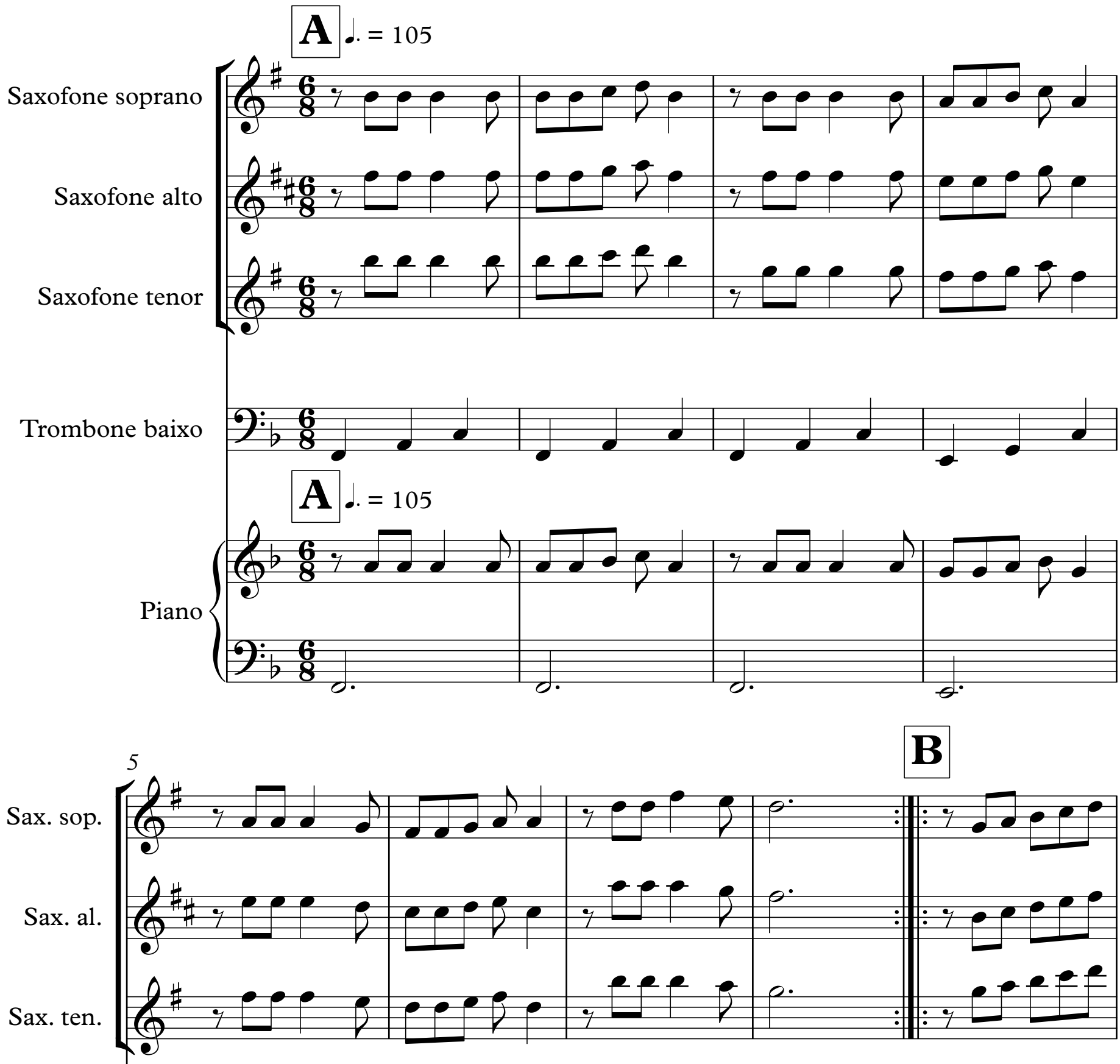

Trne. b.

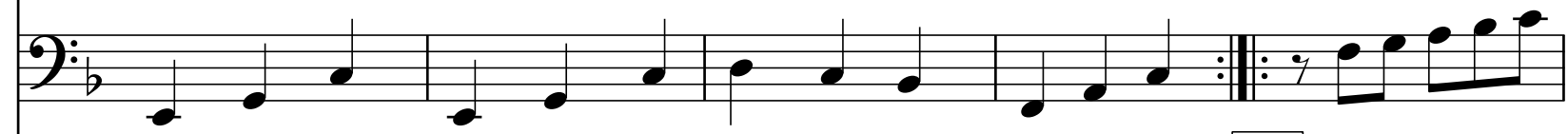

B

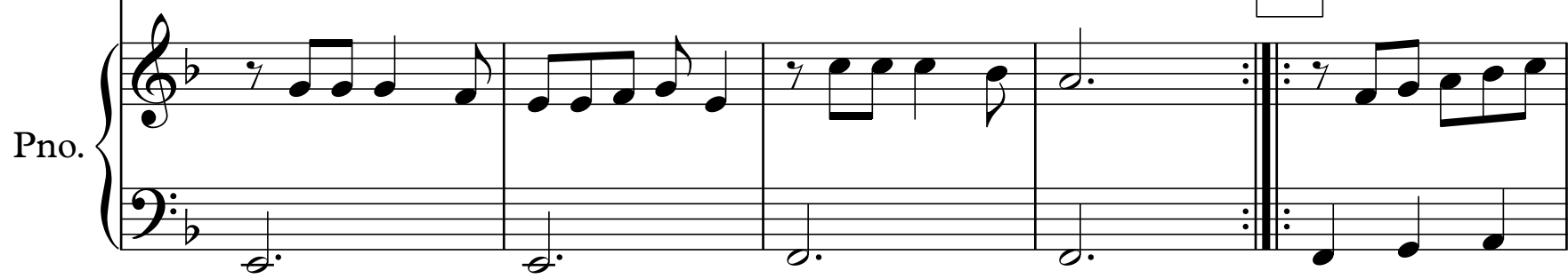




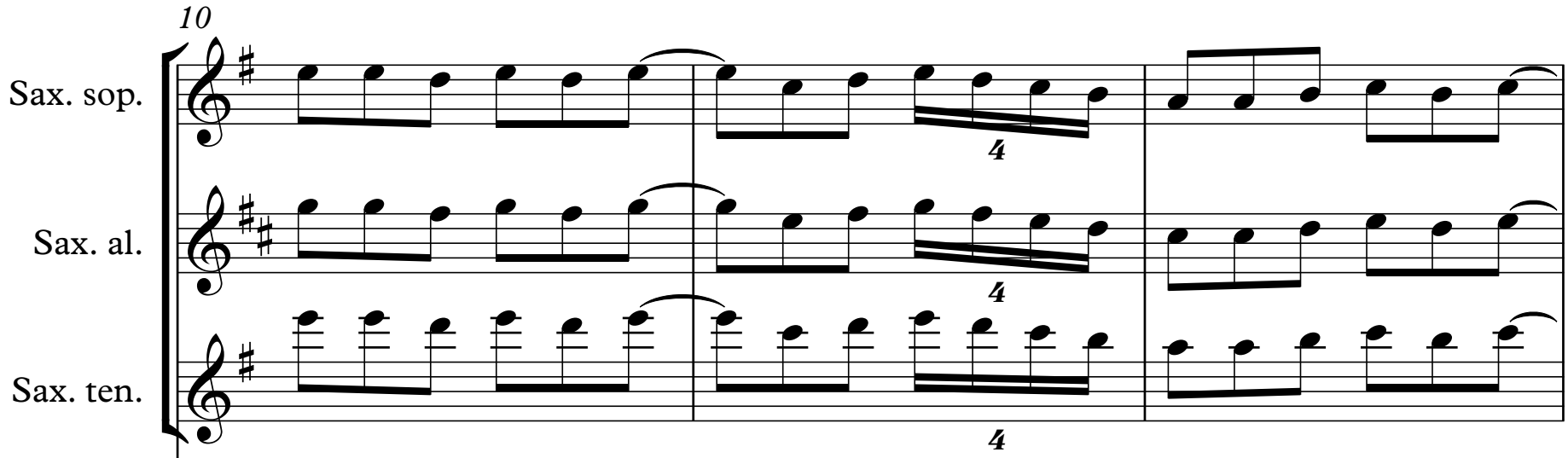

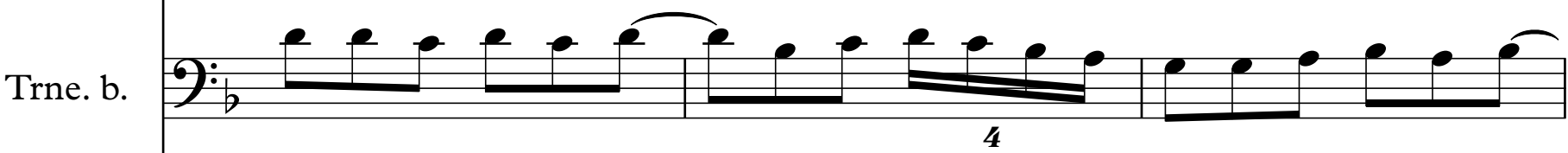

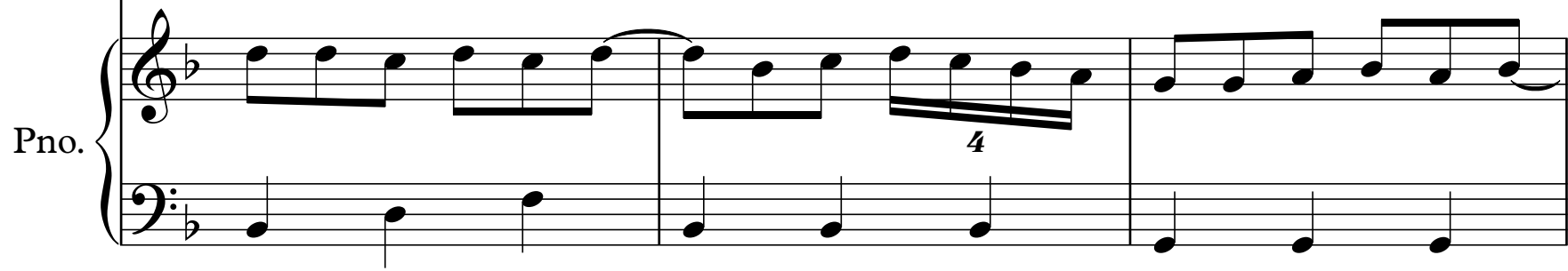

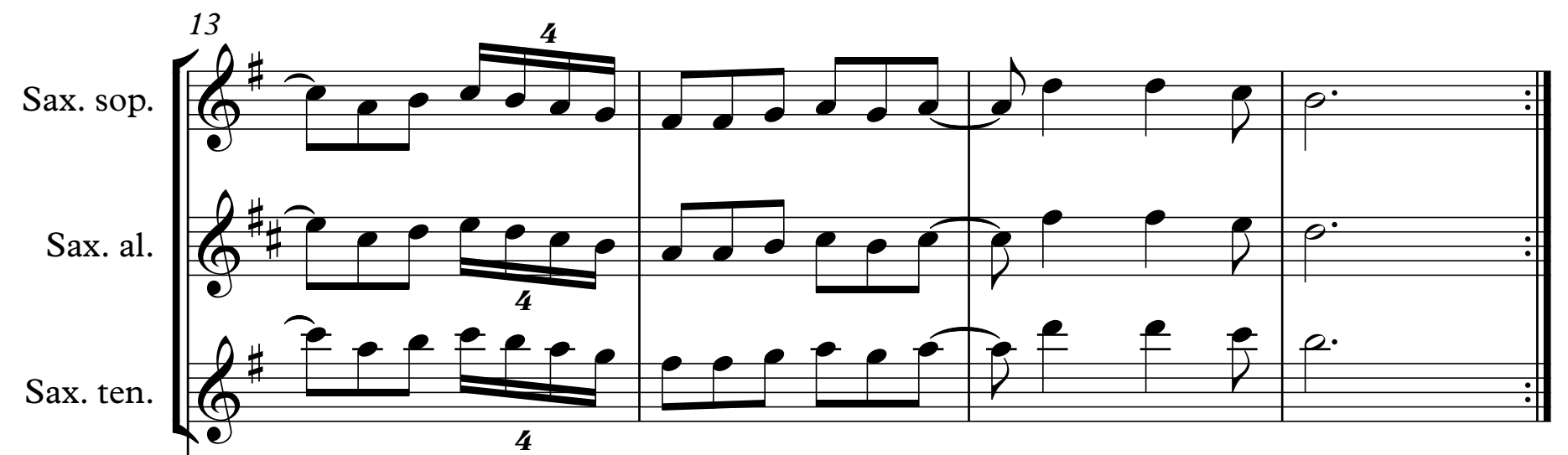

Trne. b. Pno. $\left\{\begin{array}{|l|l|l|l|l|l|l|l|l|l|}\hline \\ \hline y\end{array}\right.$ 
APÊNDICE B. GRADE DA MÚSICA NDA JEKEHAI DE MI SUERTE, AMBOPÚGUI ORQUESTRA ERRANTEPE 


\section{Nda jekehai de mi suerte, ambopúva Orquestra Errantepe}

Odilio Román

Orquestra Errante
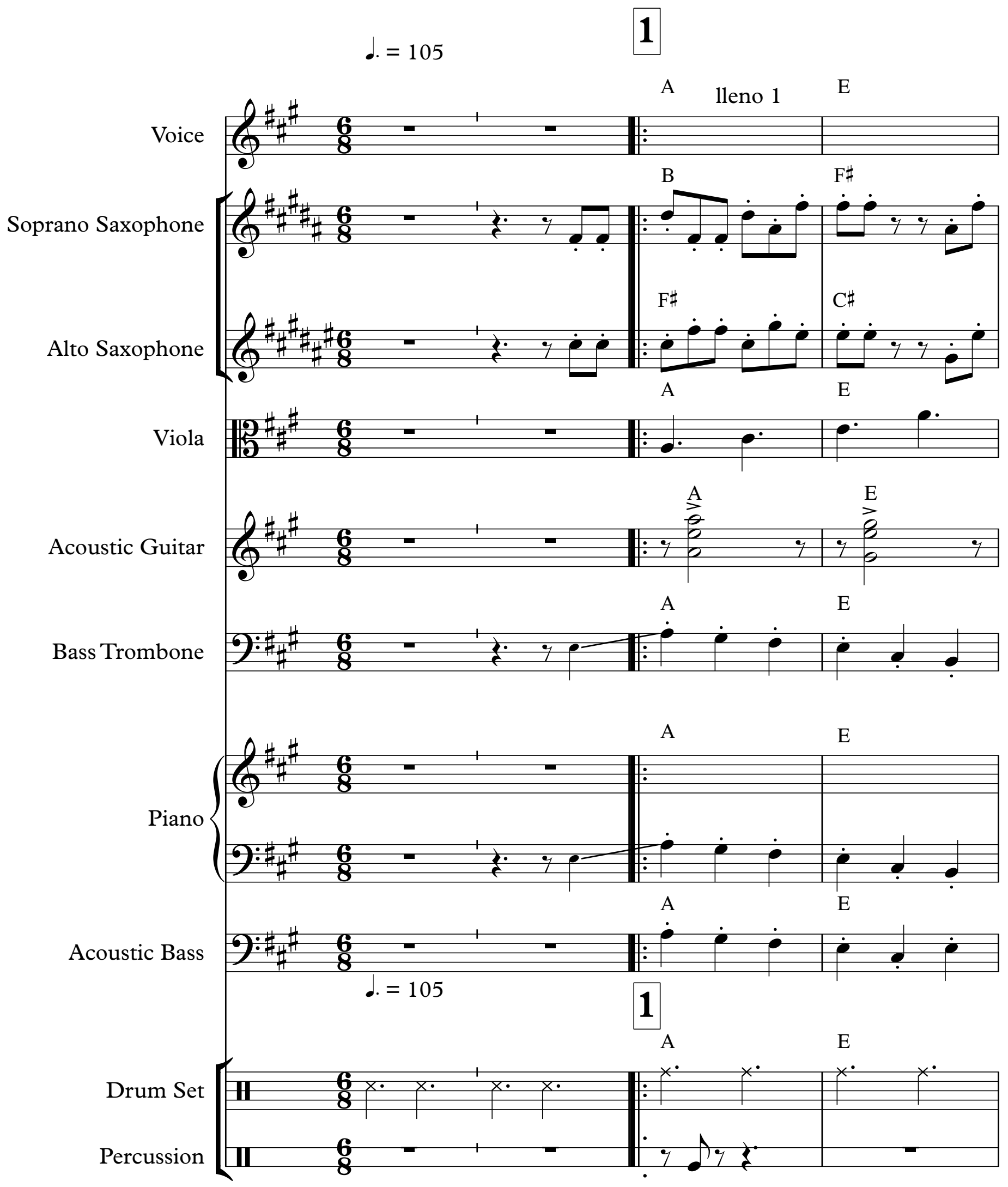
2

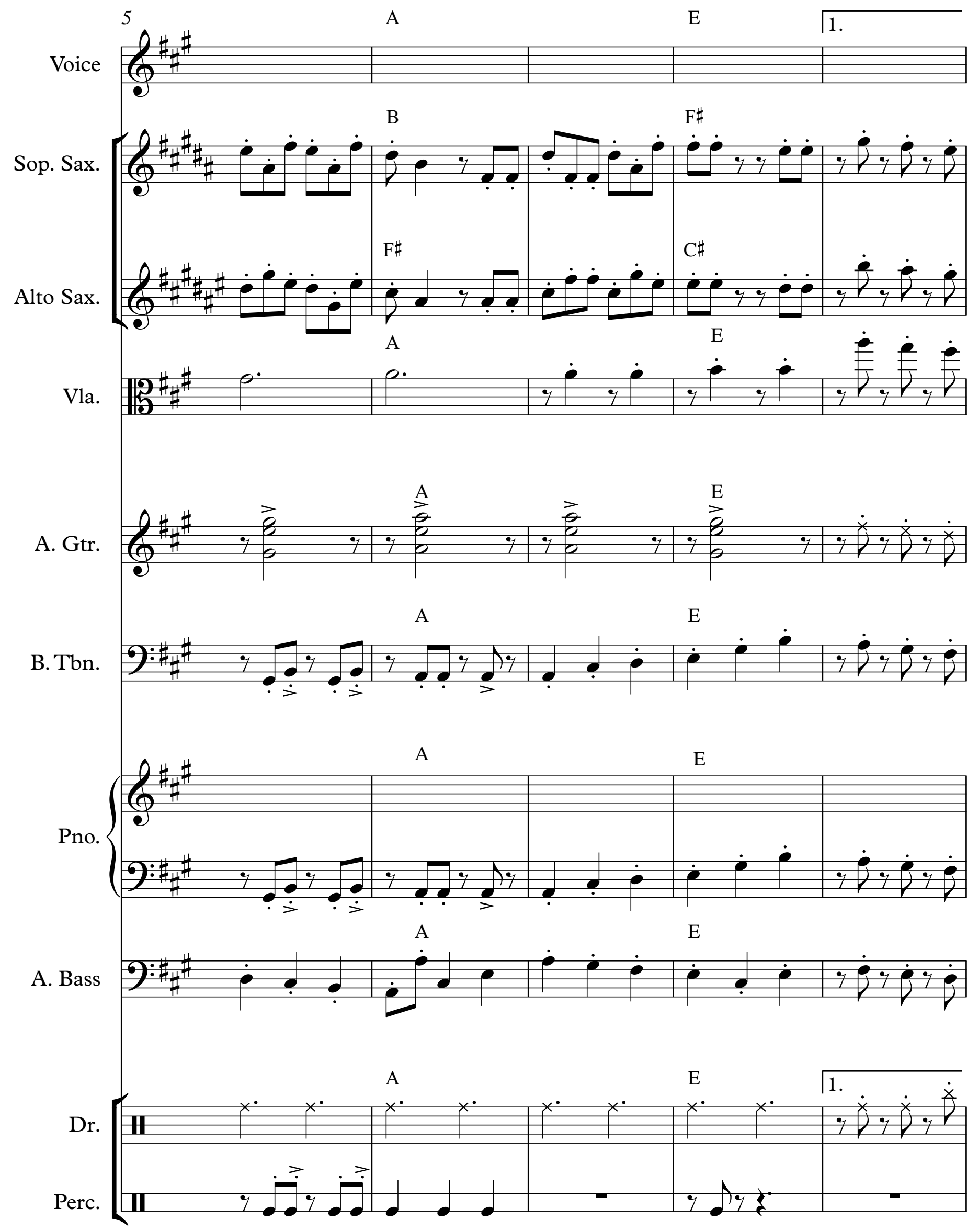



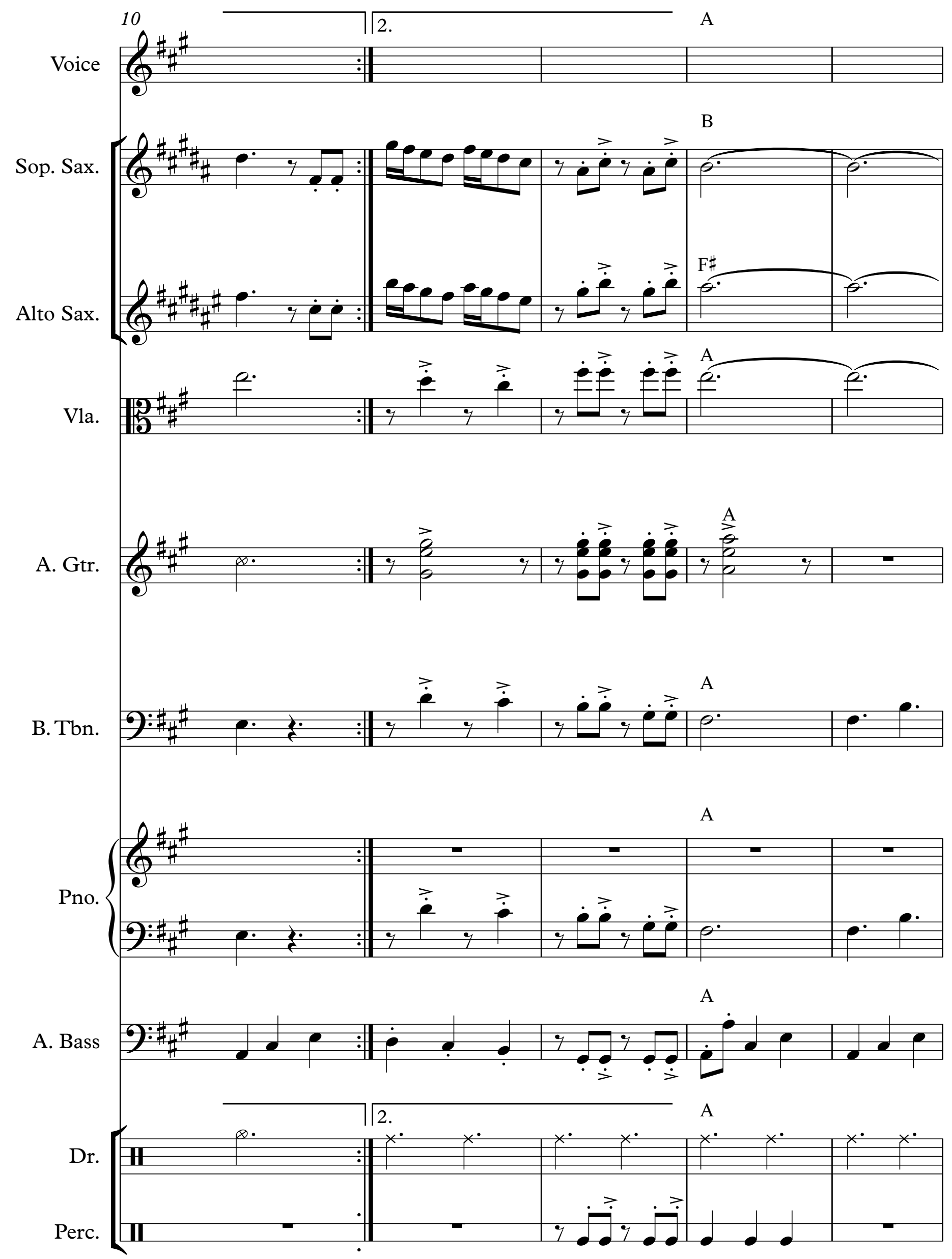


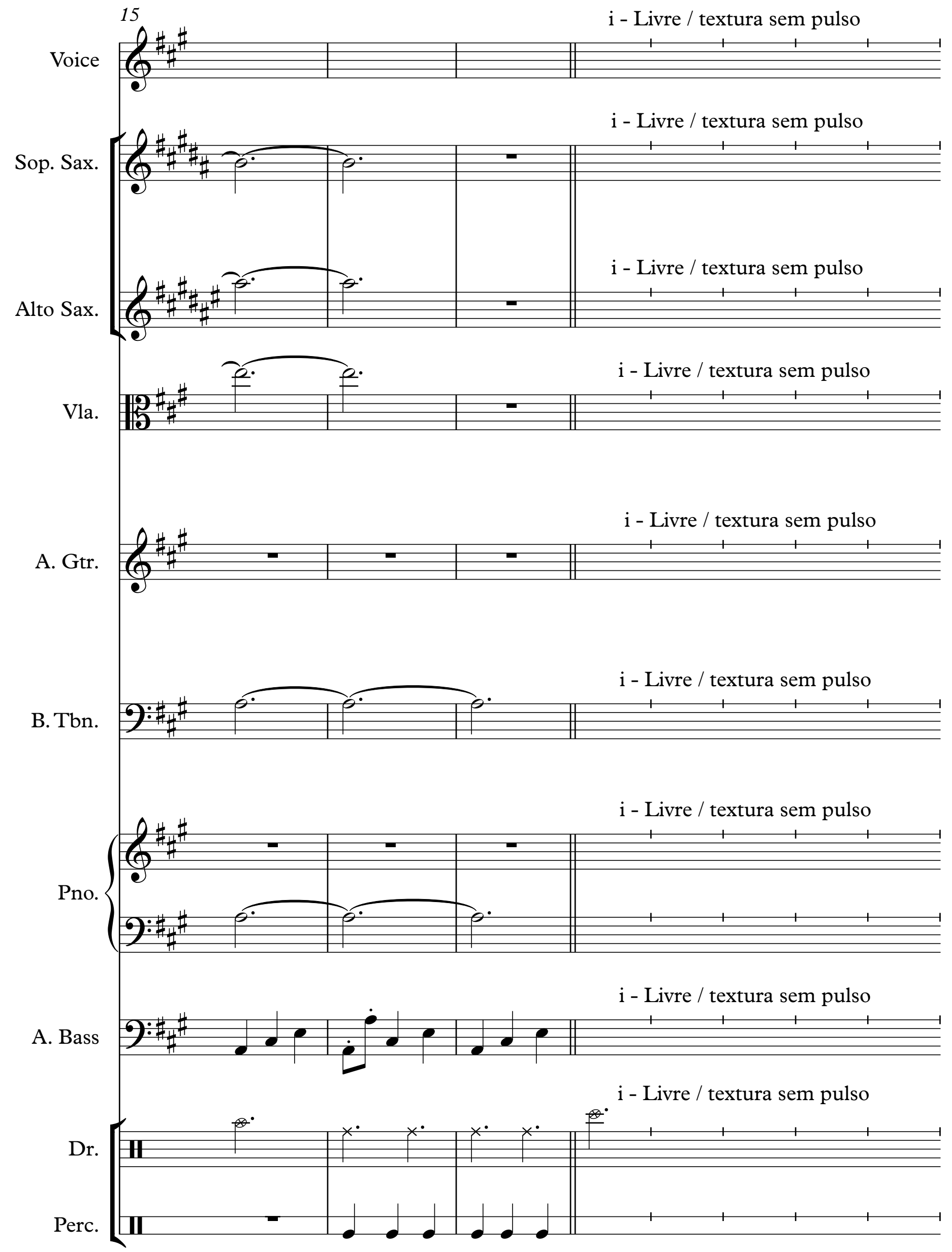




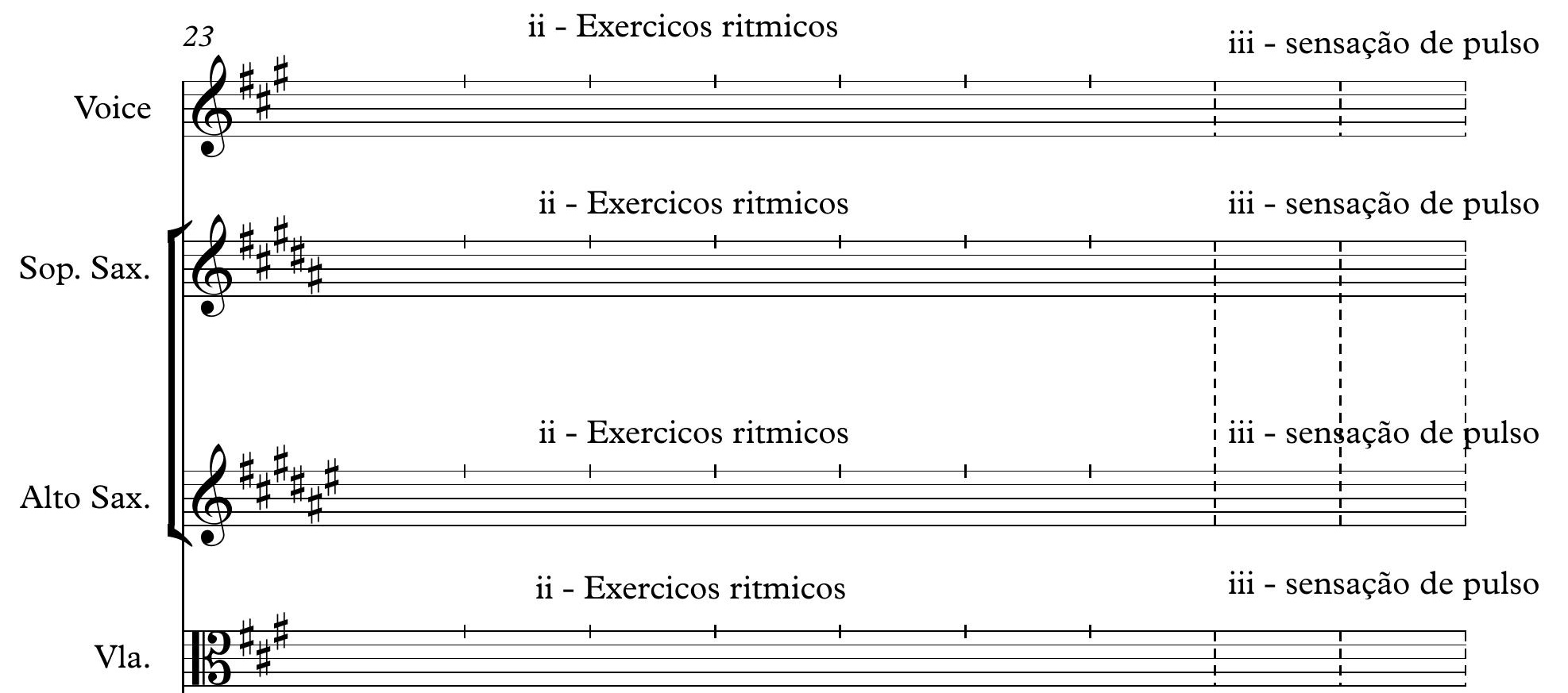

A. Gtr.

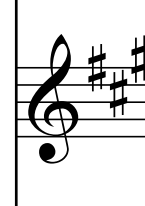

ii - Exercicos ritmicos

iii - sensação de pulso

B. Tbn.

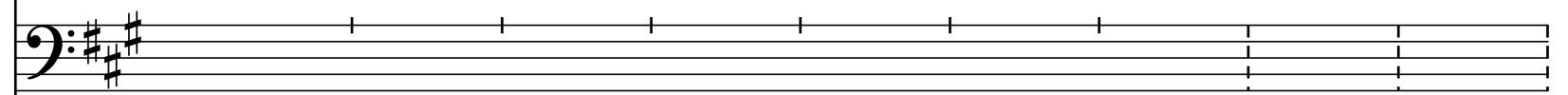
ii - Exercicos ritmicos
iii - sensação de pulso

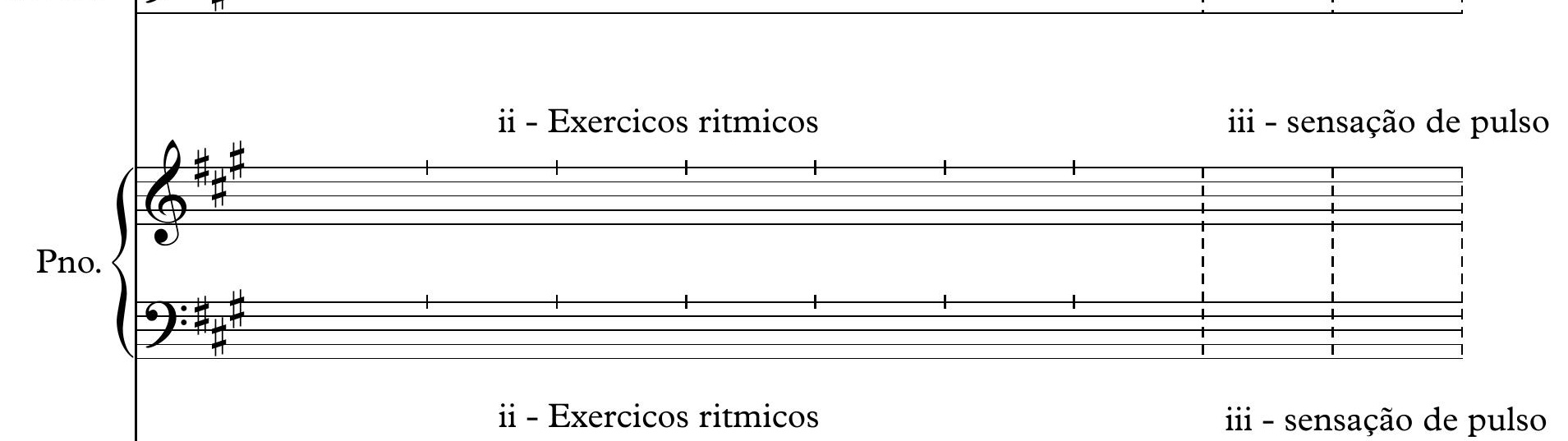

A. Bass
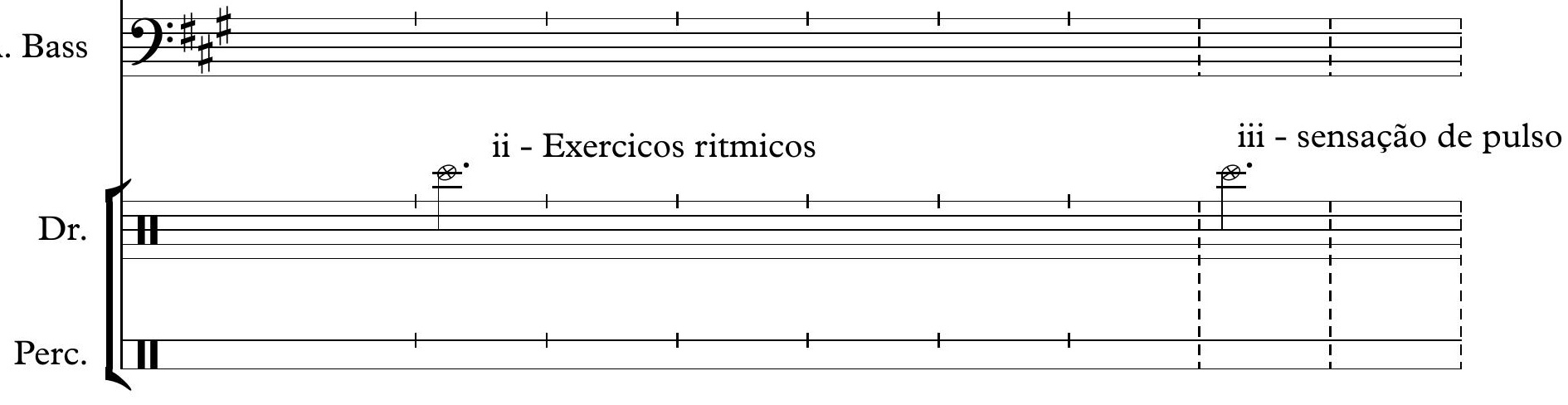


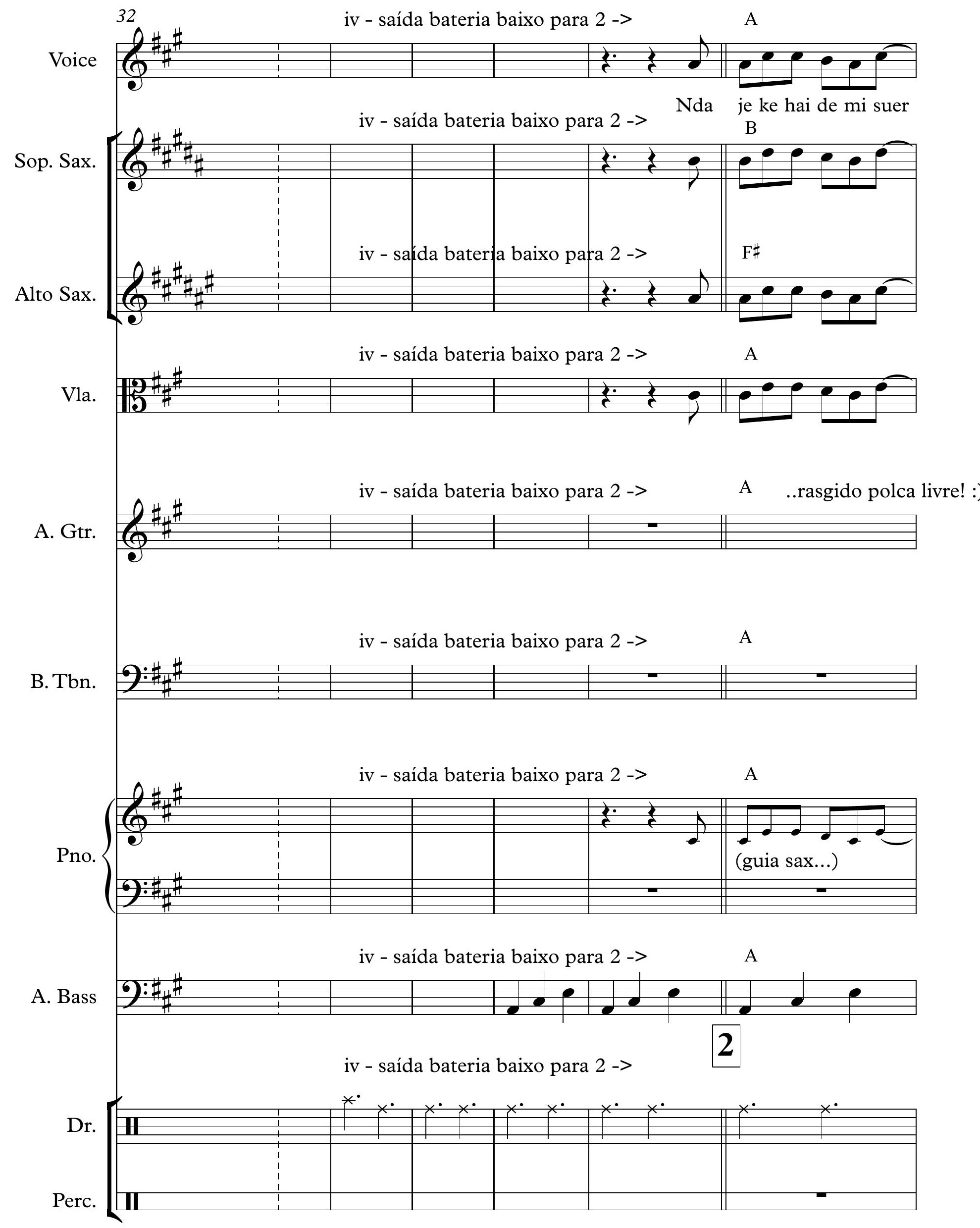




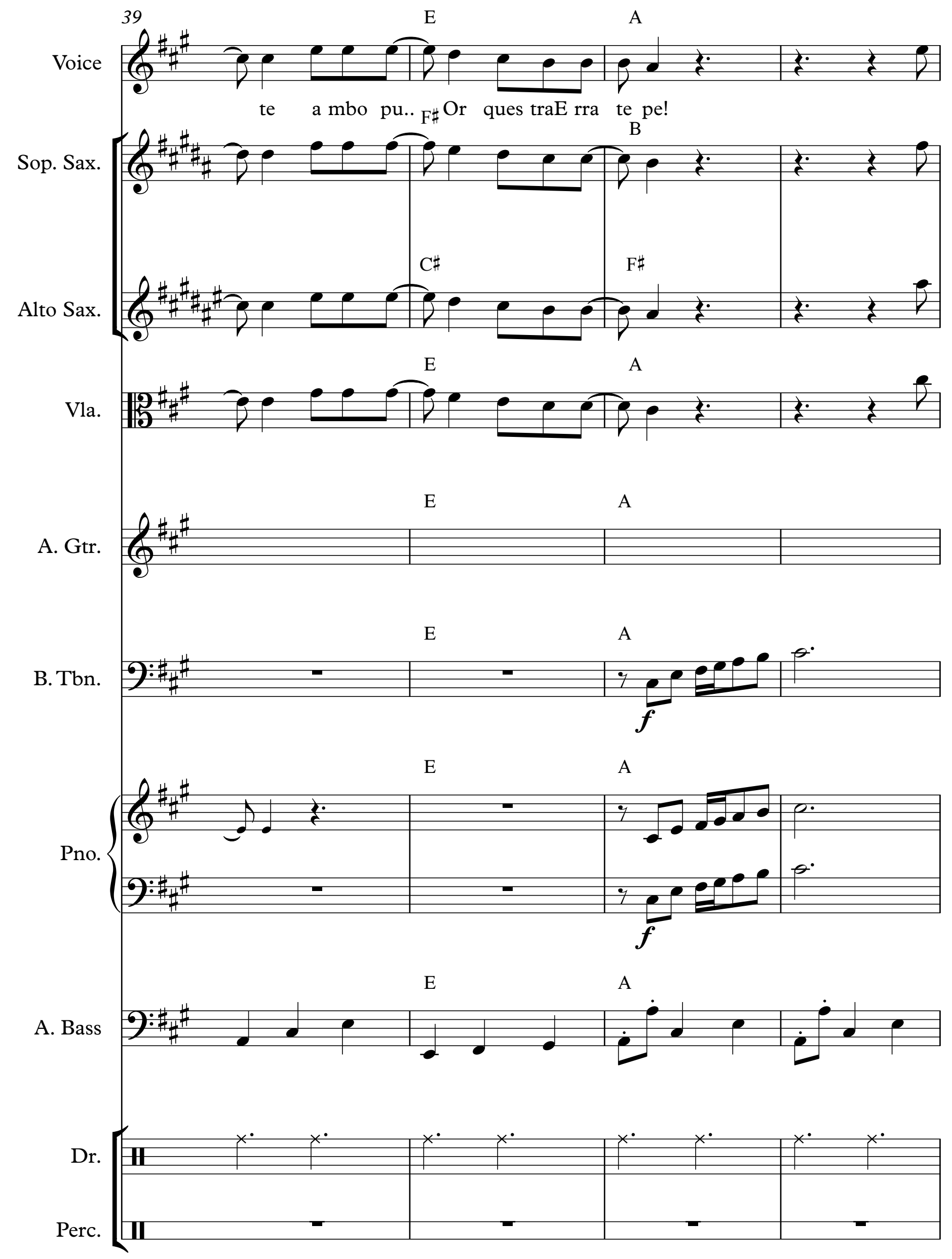




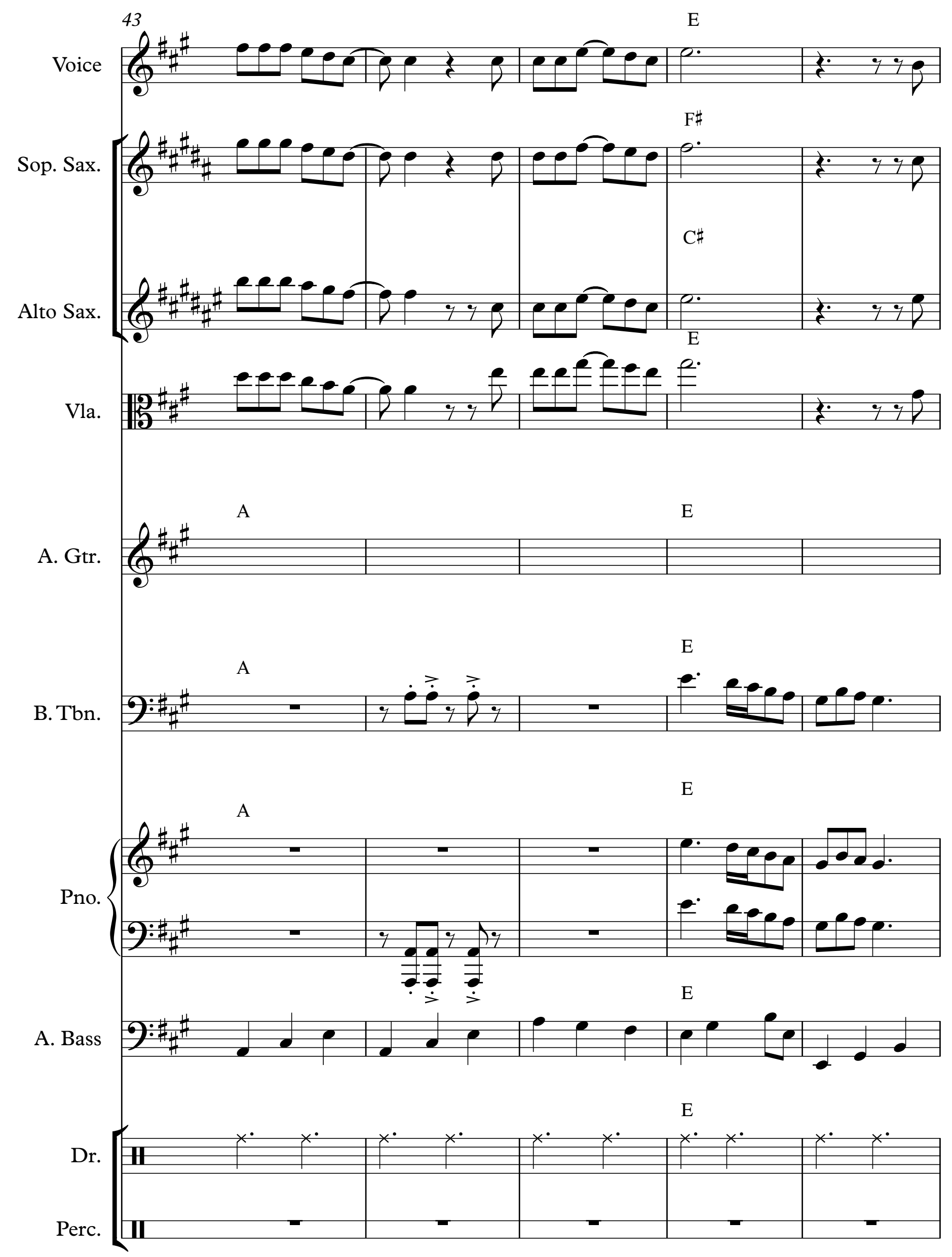




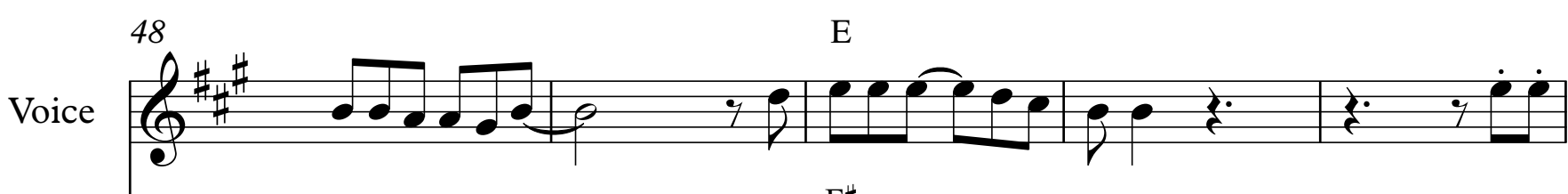
$\mathrm{F} \#$

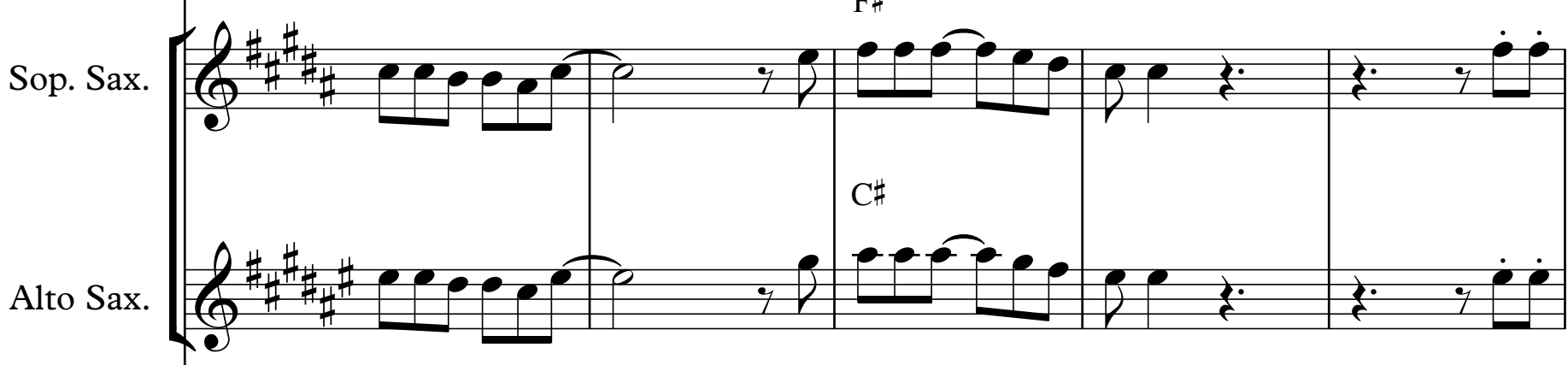

Vla.

E

A. Gtr.

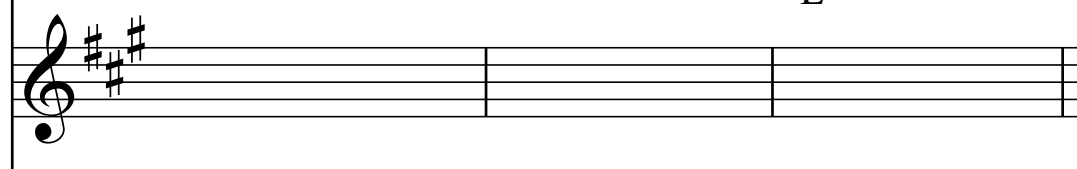

B. Tbn.

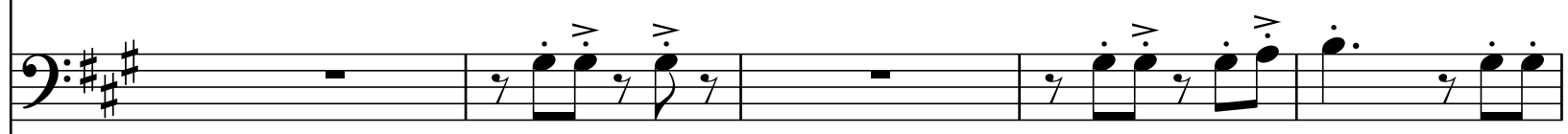

A. Bass

E
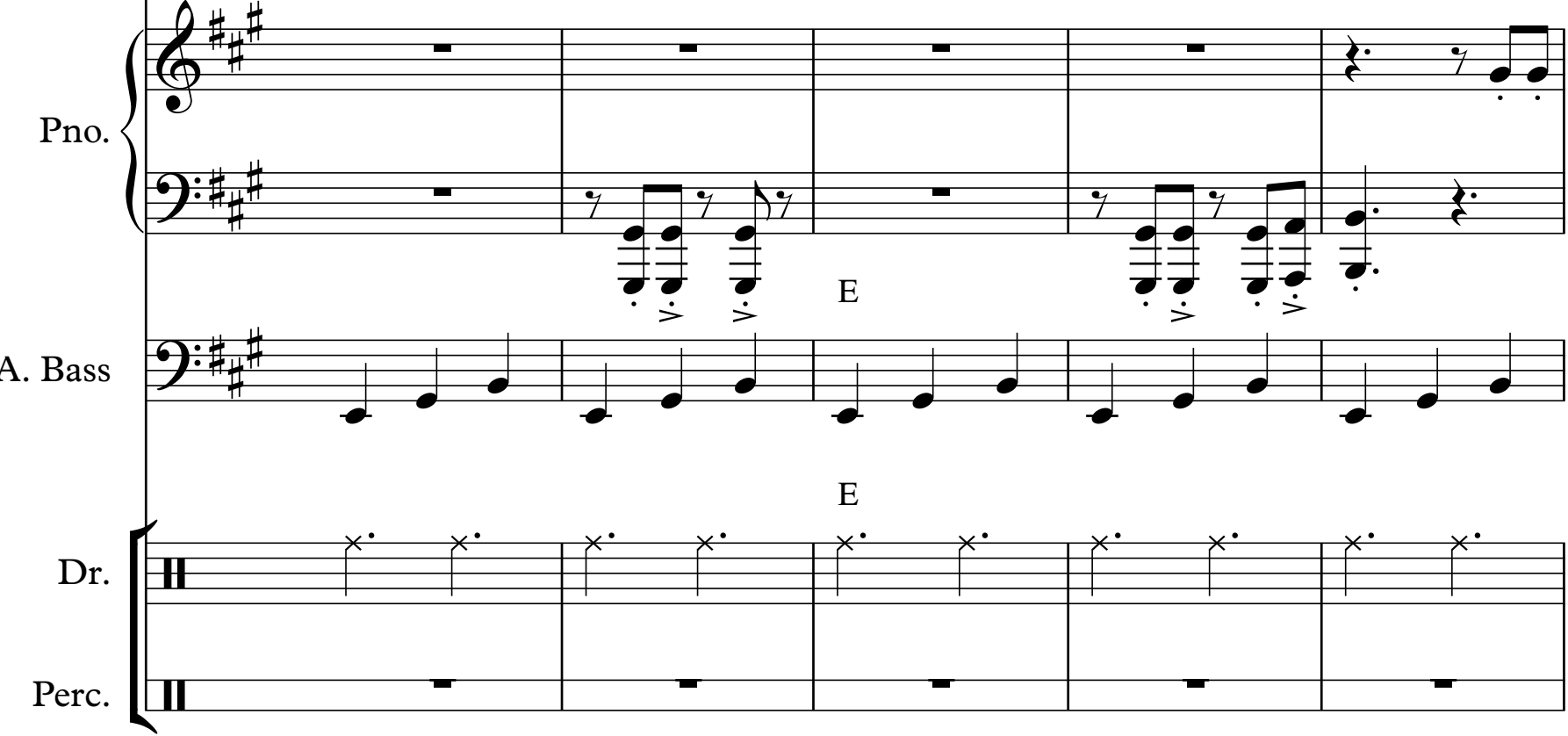


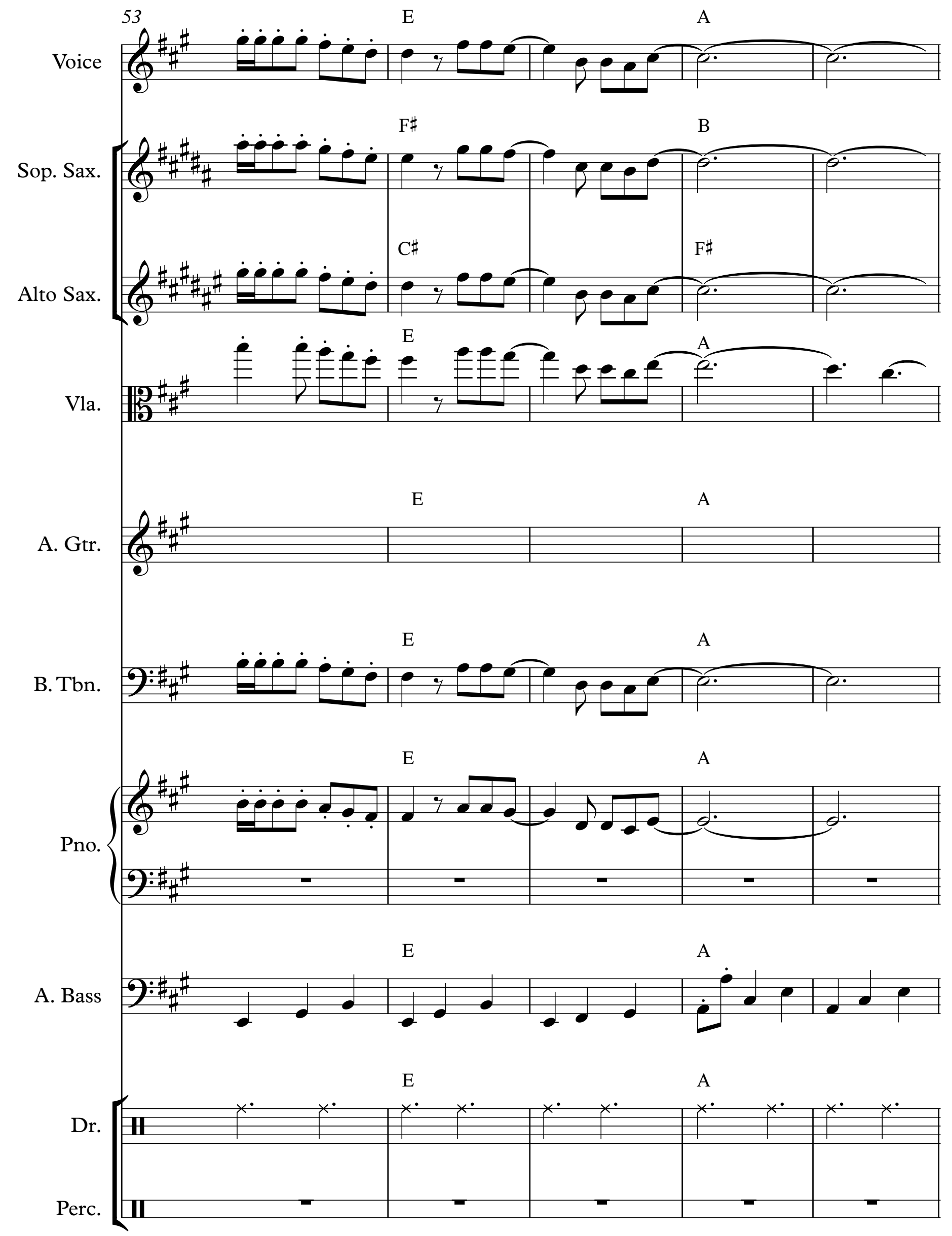




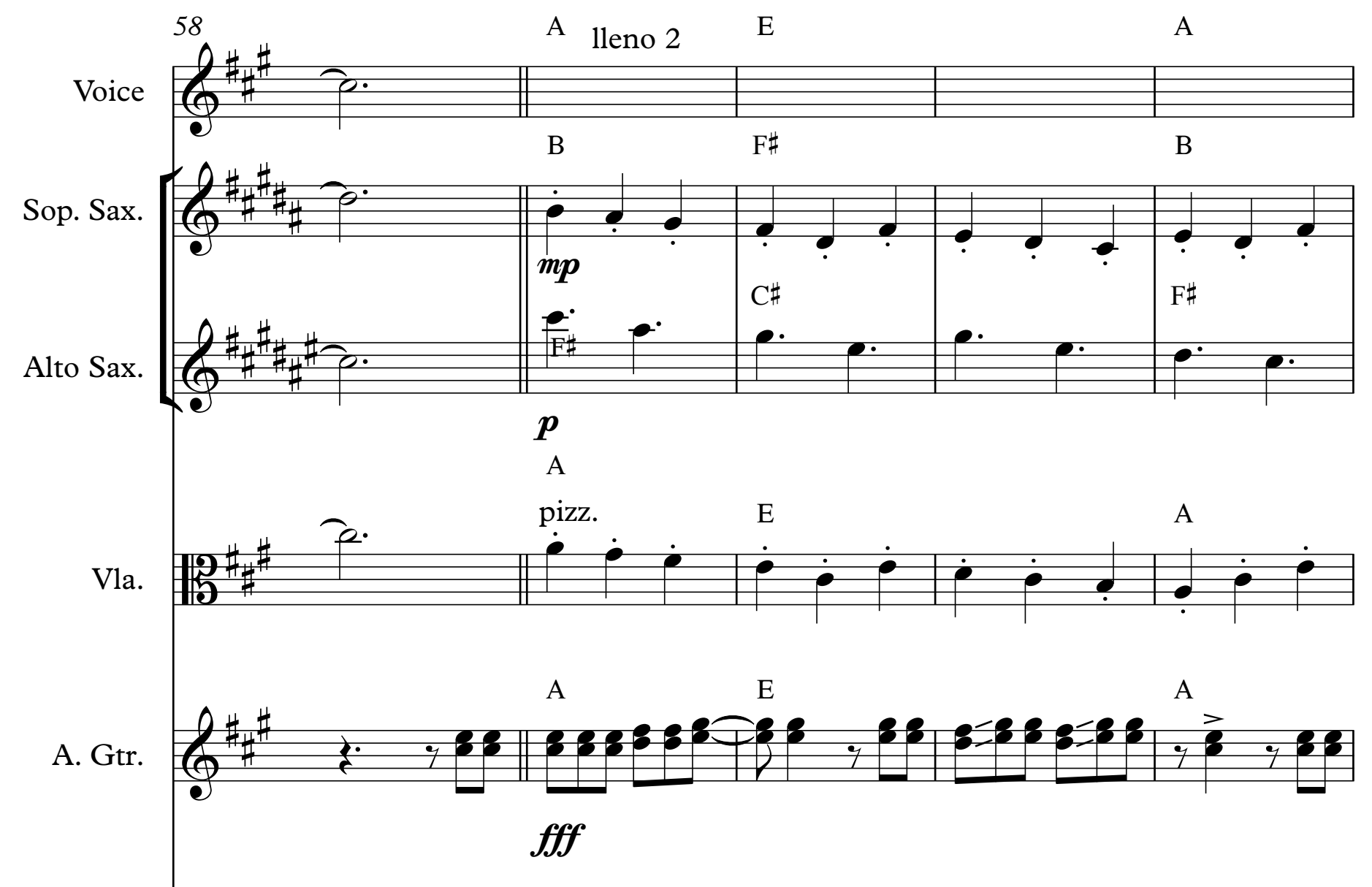

A lleno 2 E A

B. Tbn.
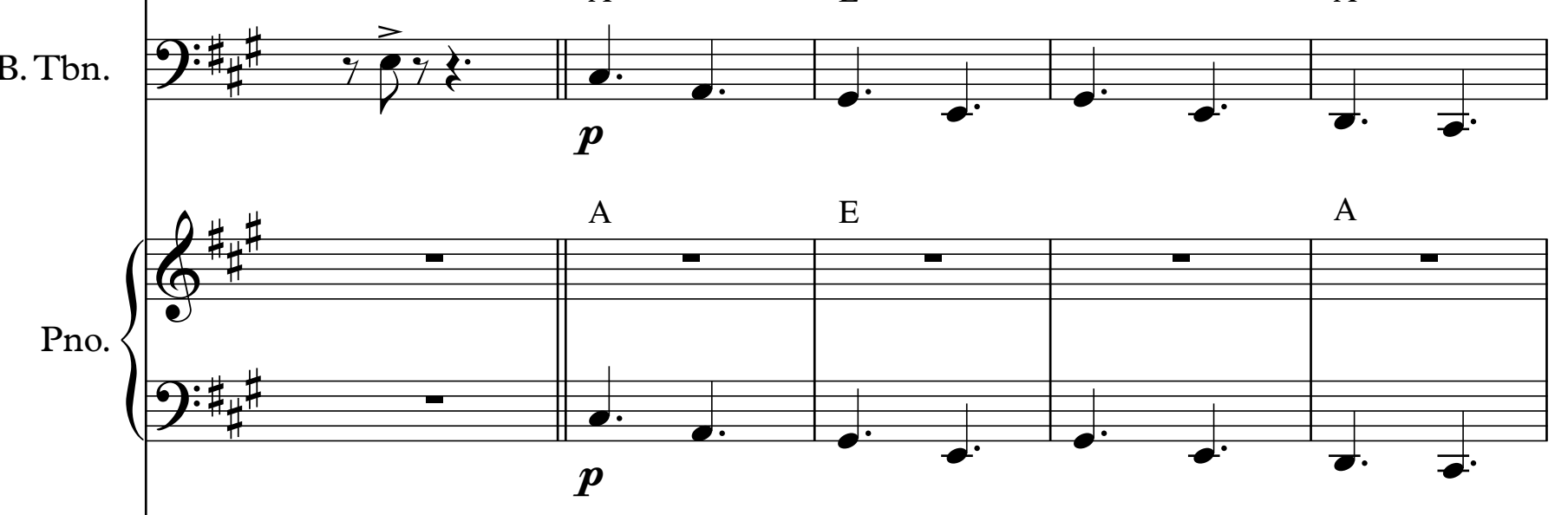

A. Bass
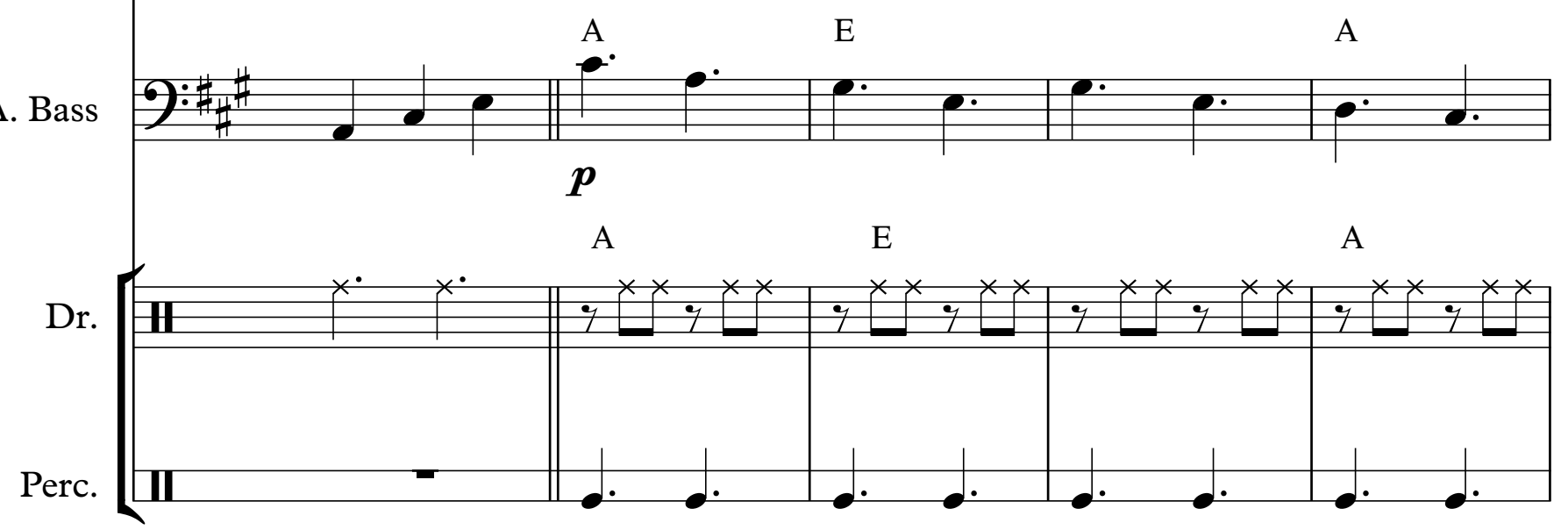


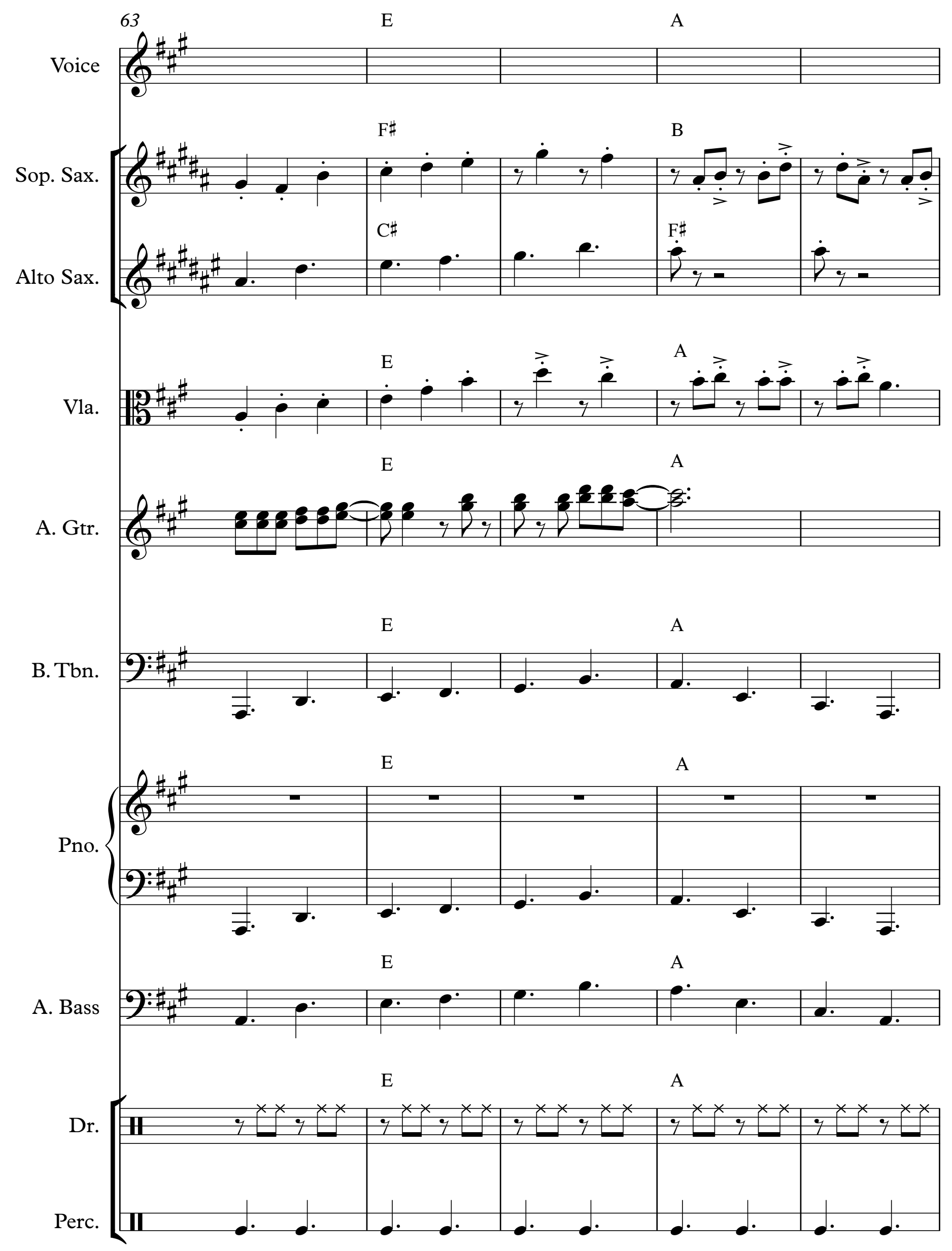




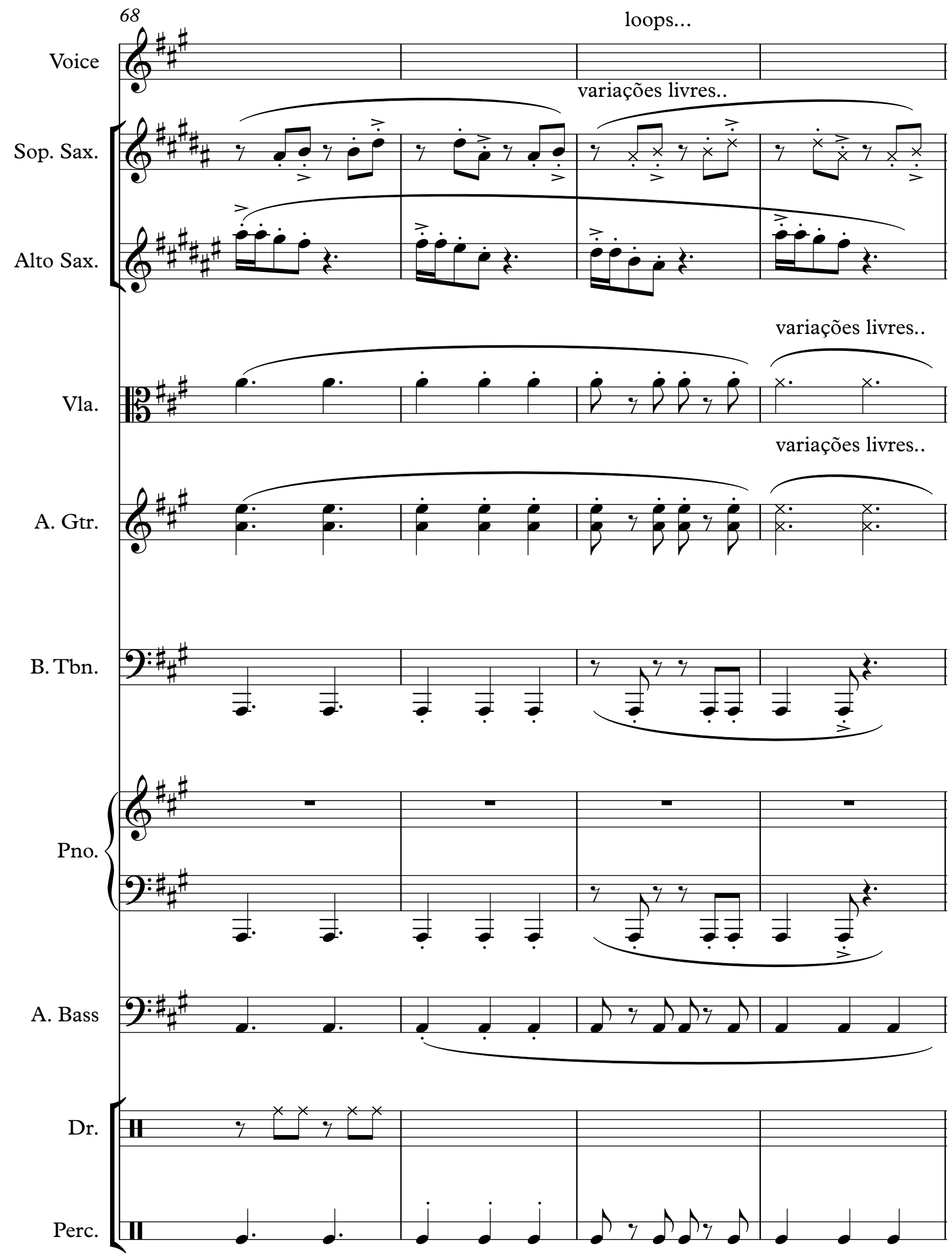




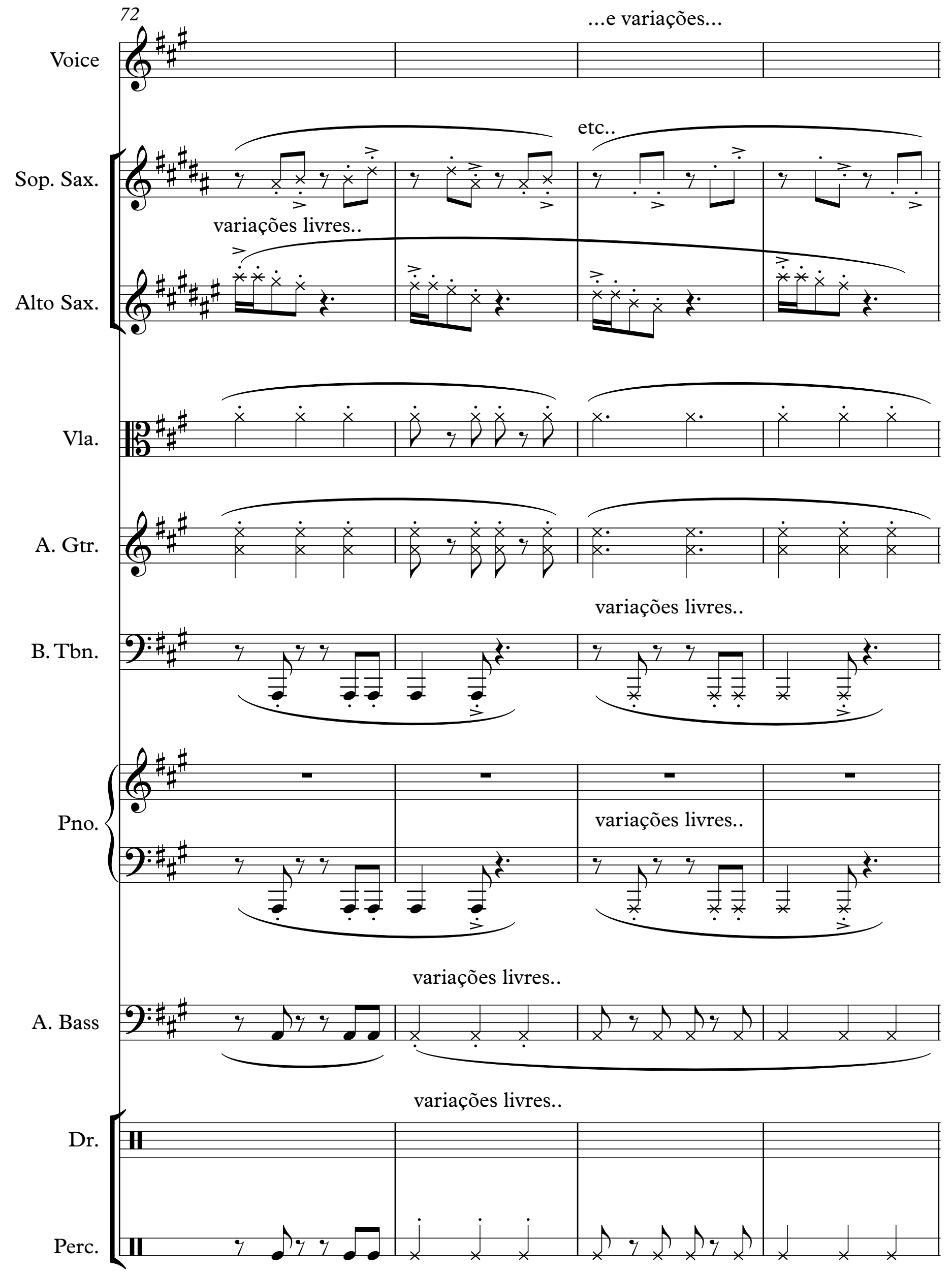




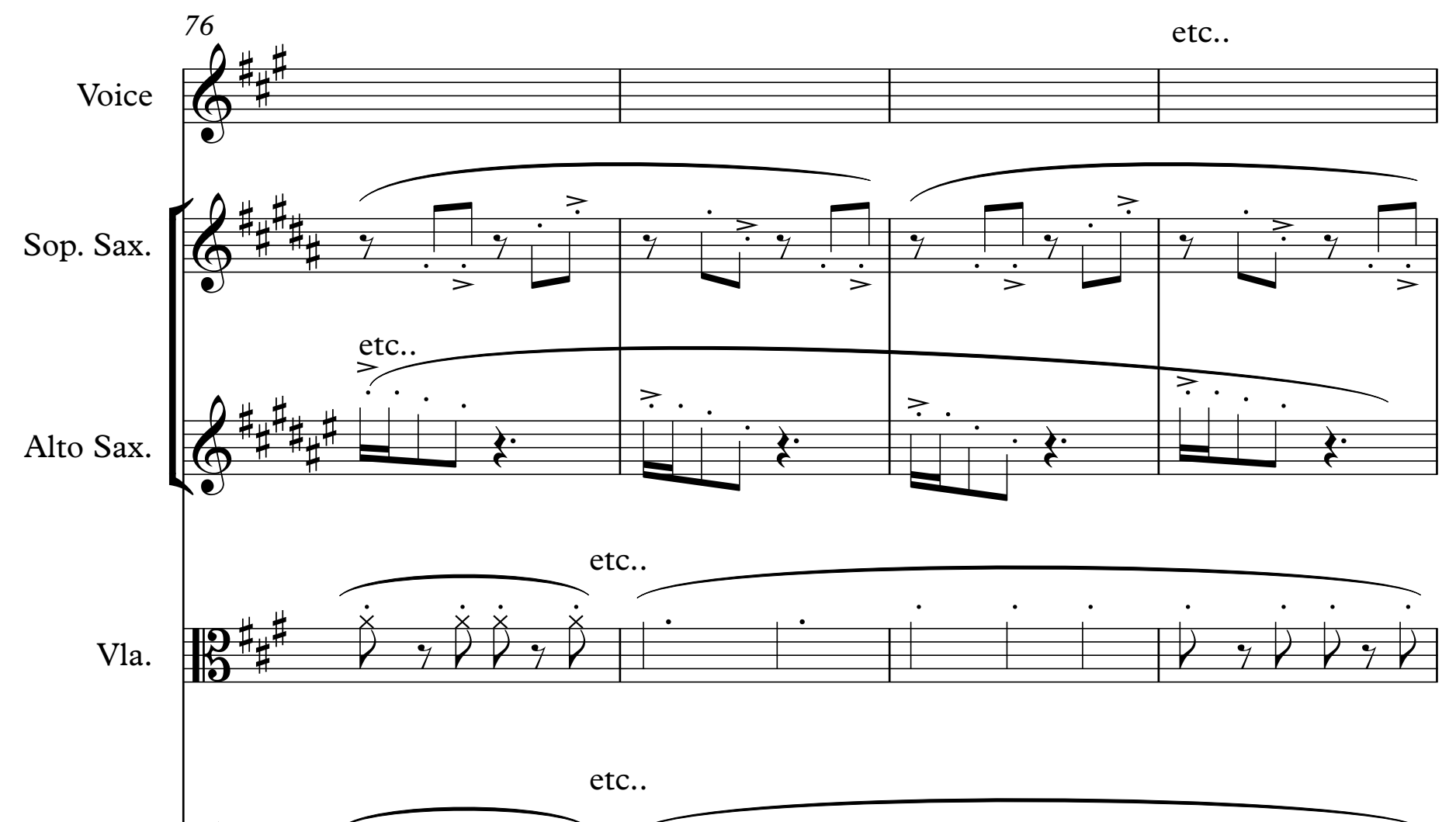

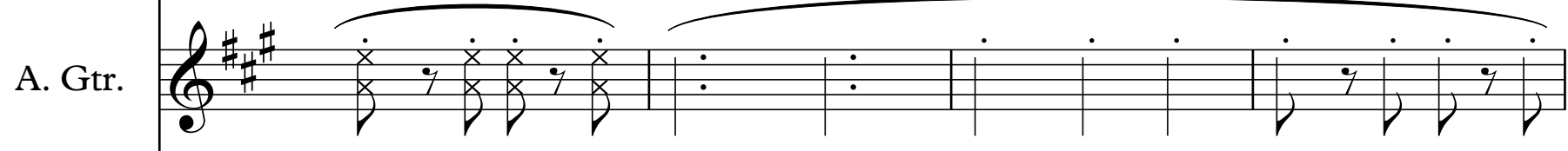
etc. .

B.Tbn.

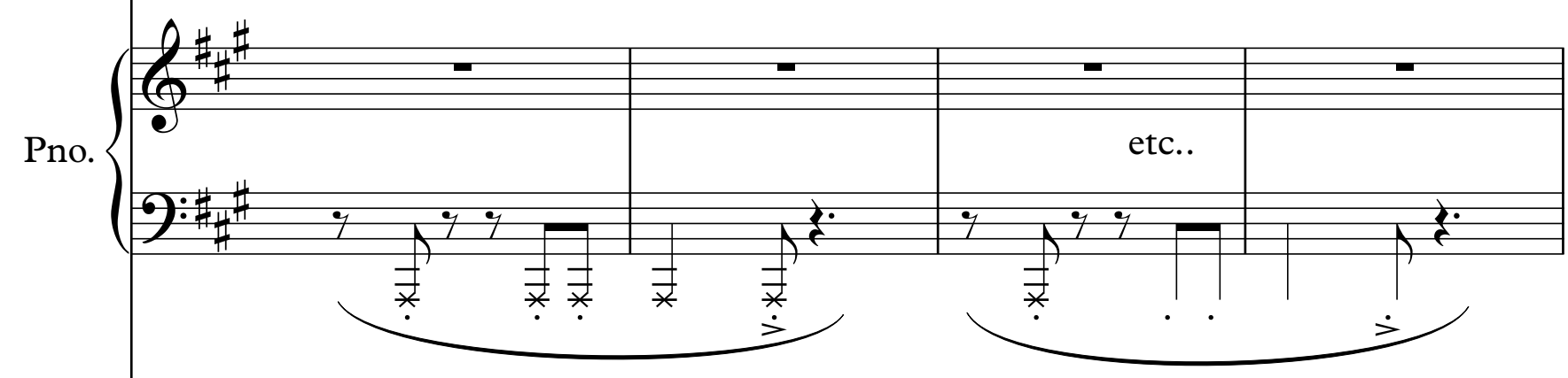

etc..

A. Bass

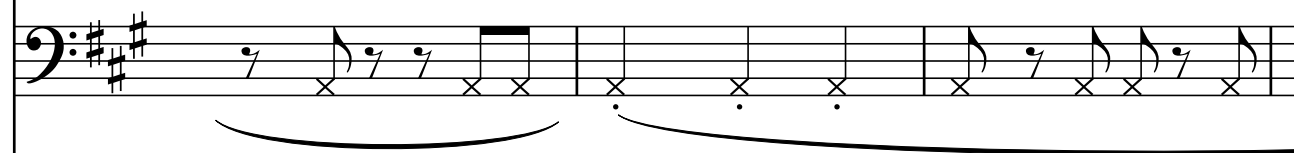

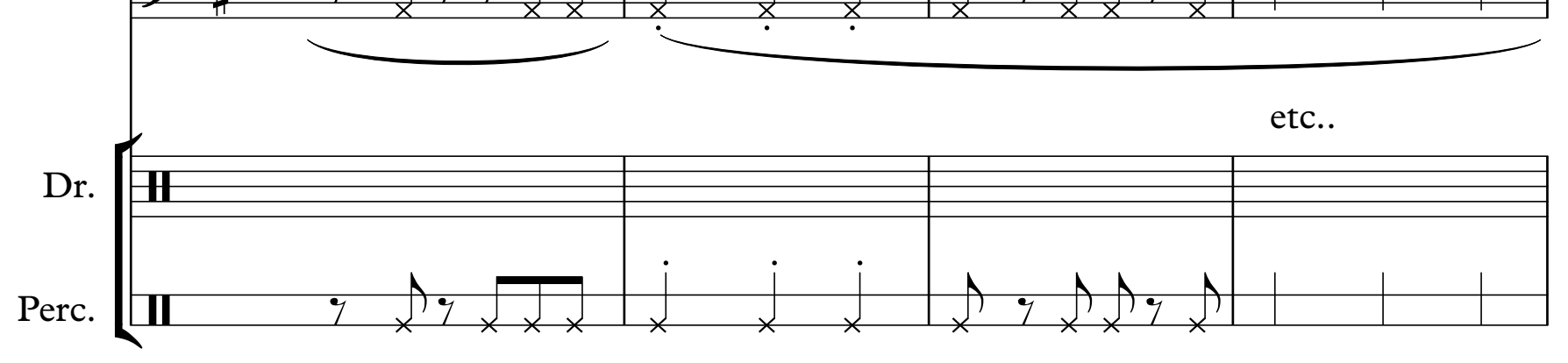




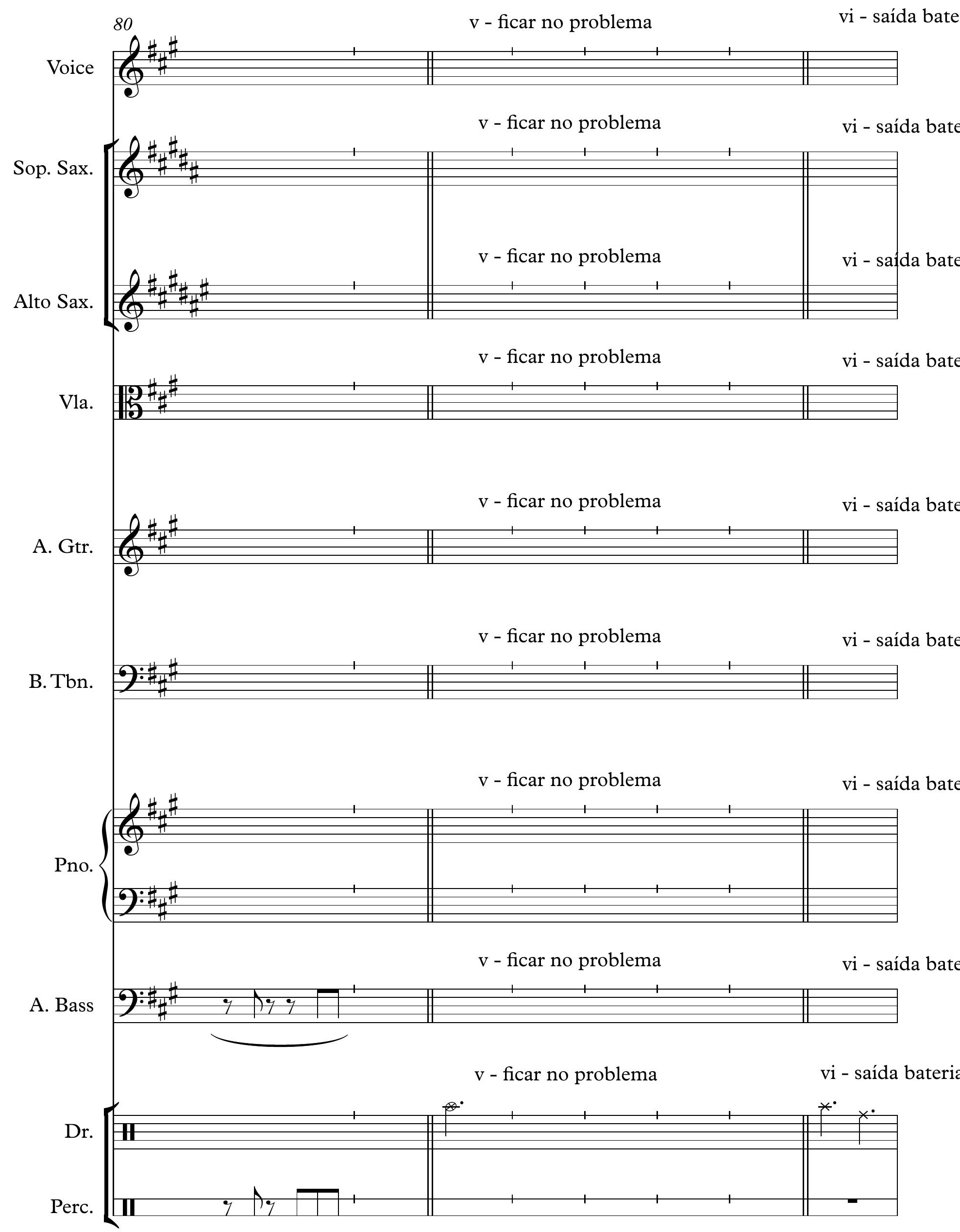


3 A

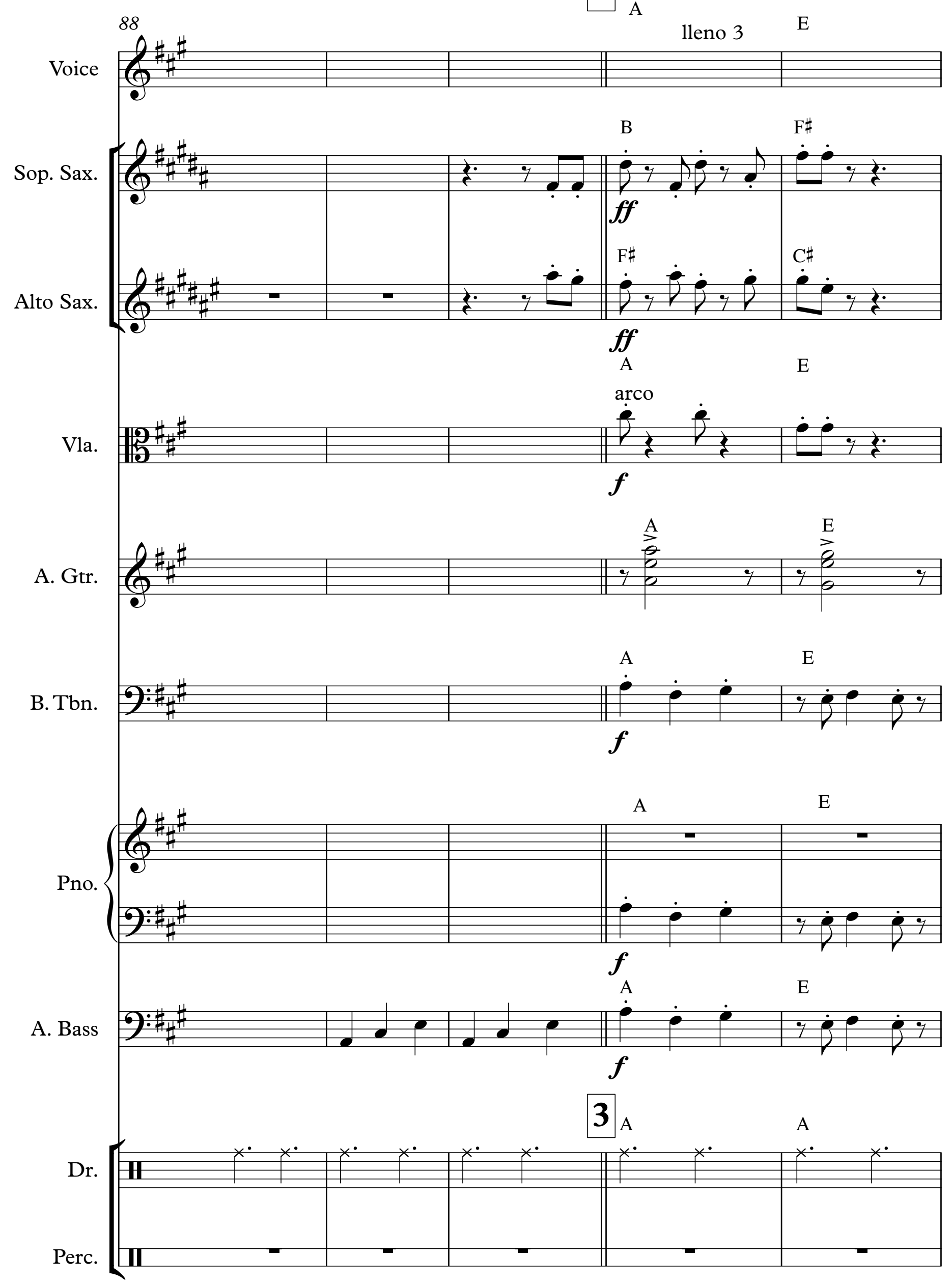




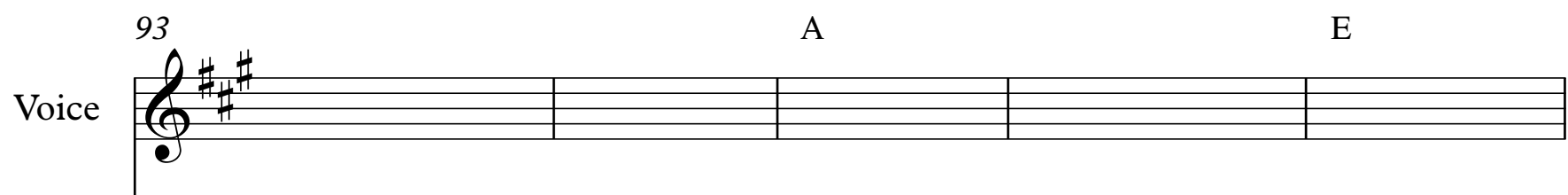

B $\quad F^{\#}$

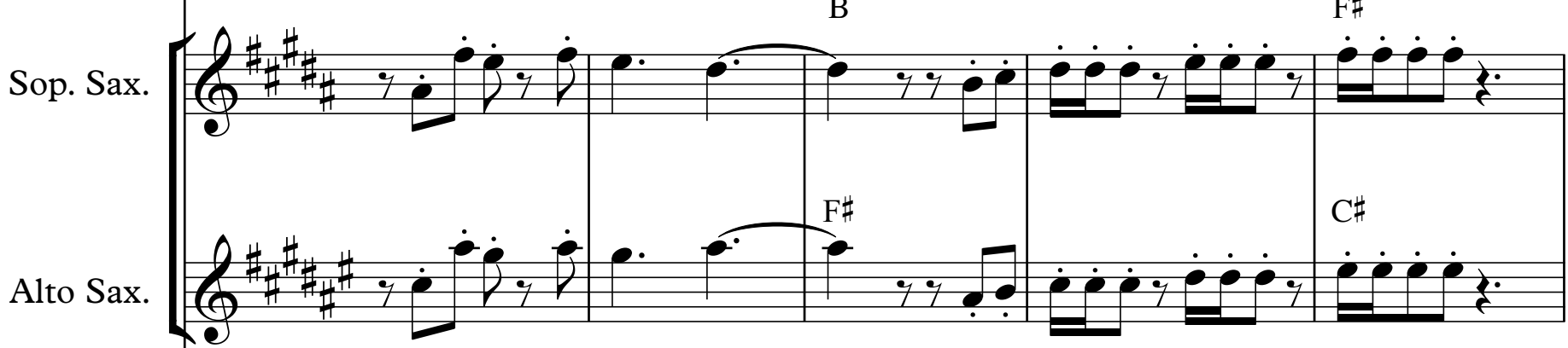

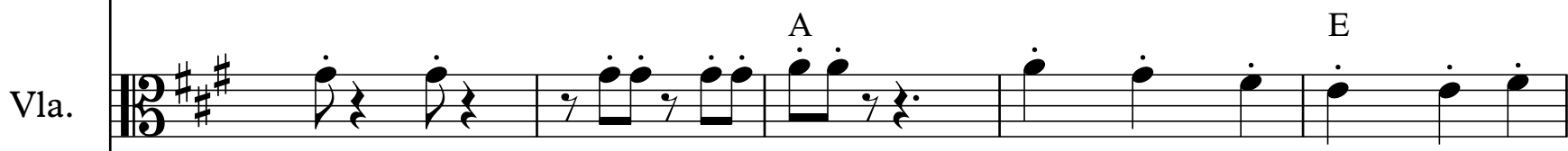

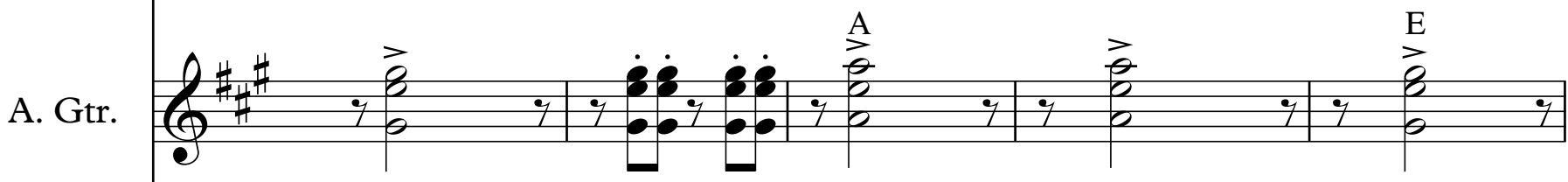

A

E

B. Tbn.

官:

A

E

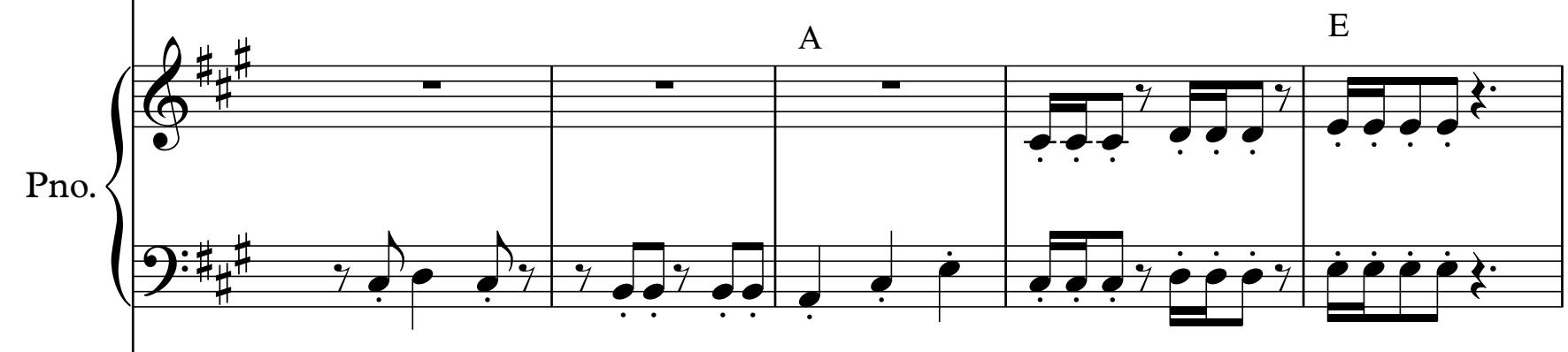

A

E

A. Bass

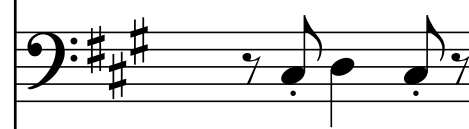

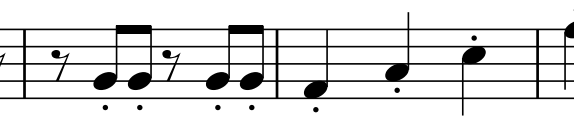

A

E

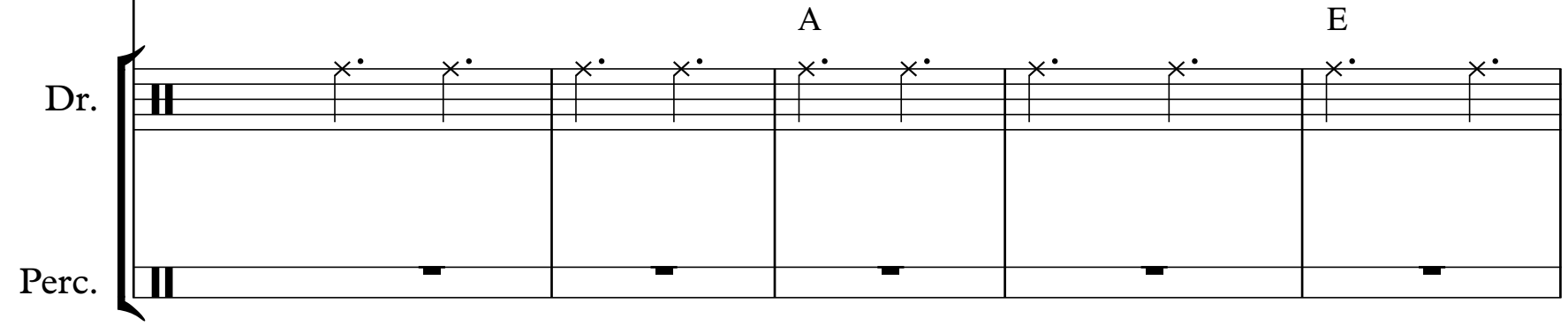




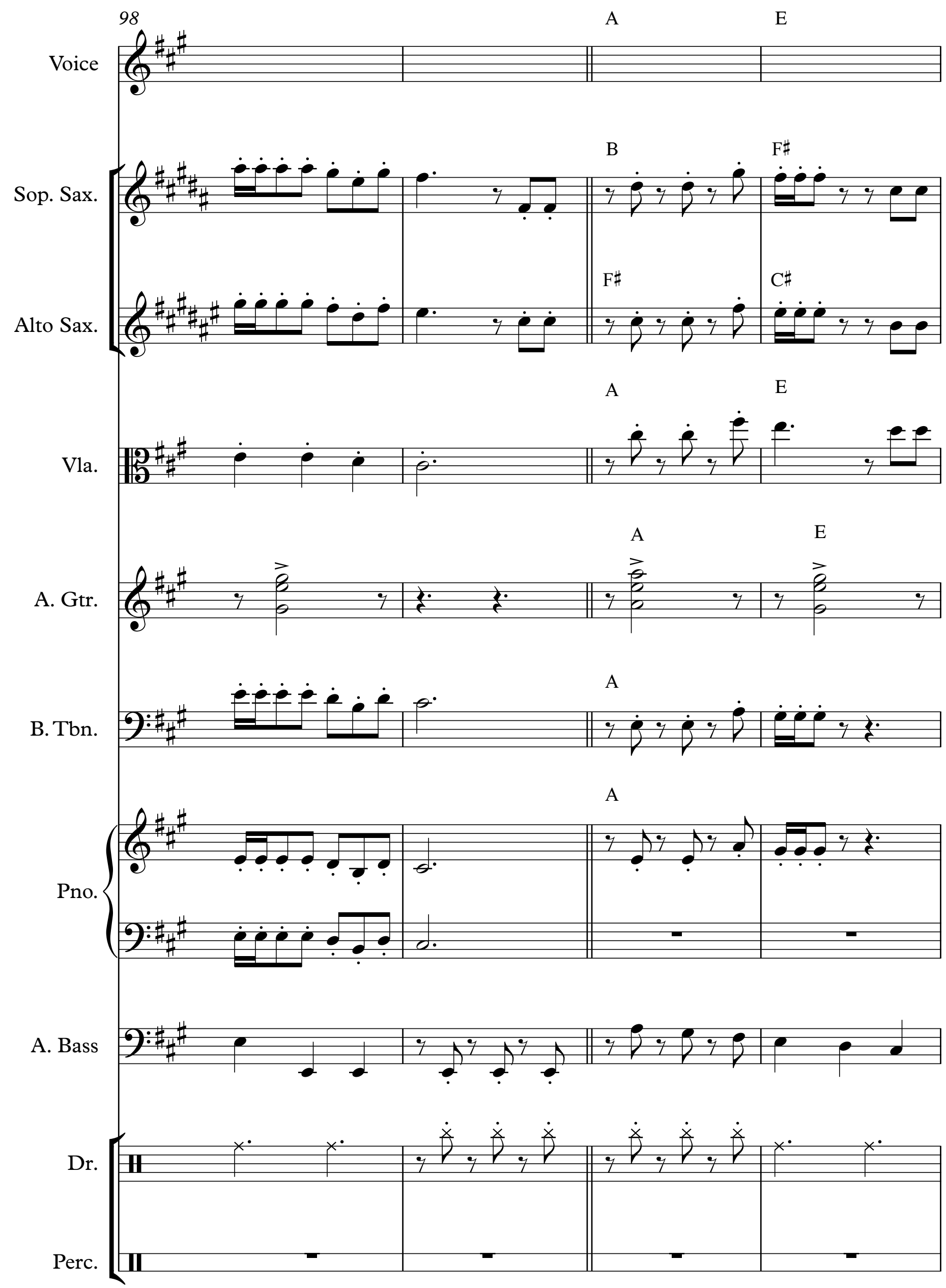




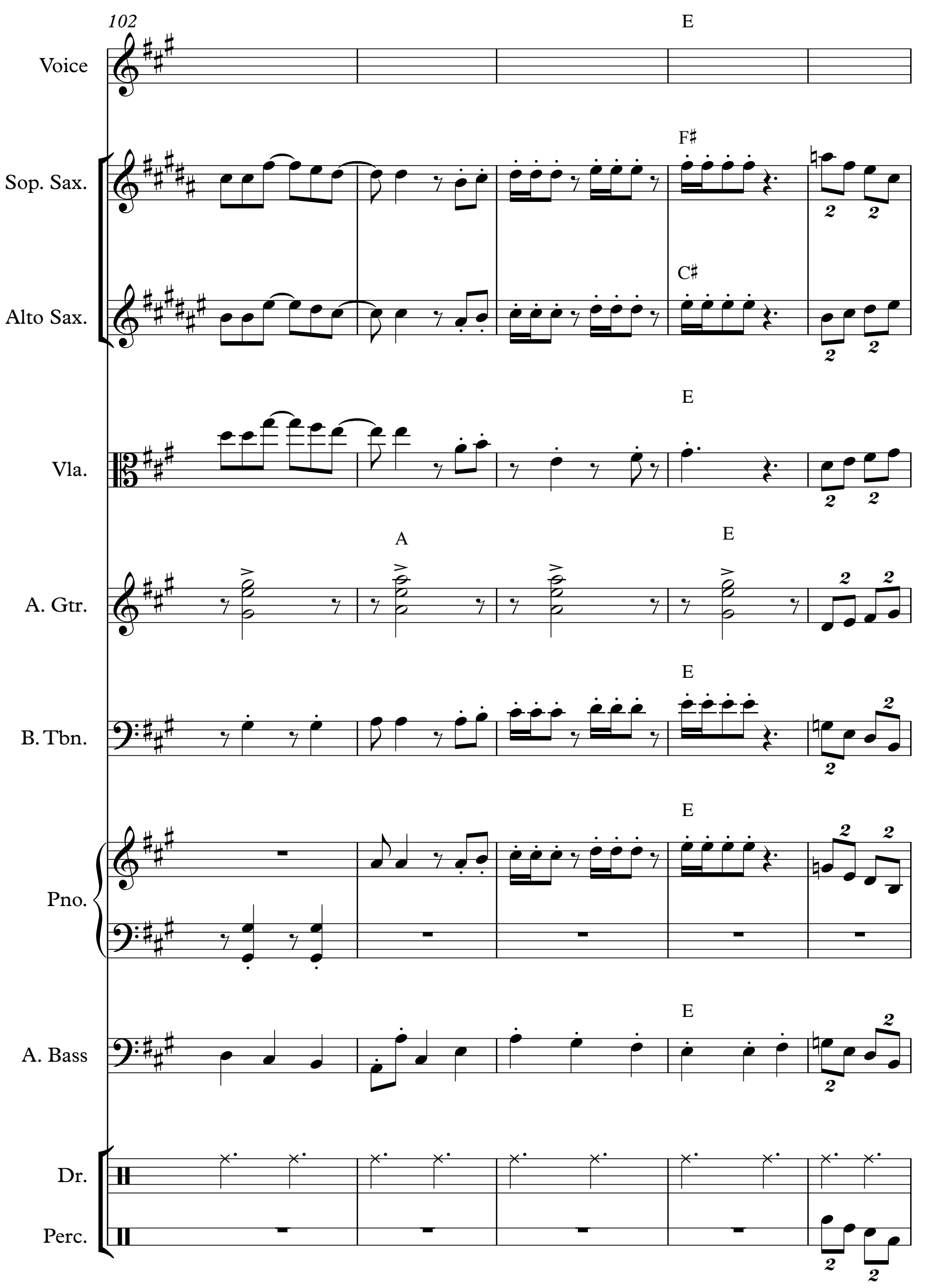




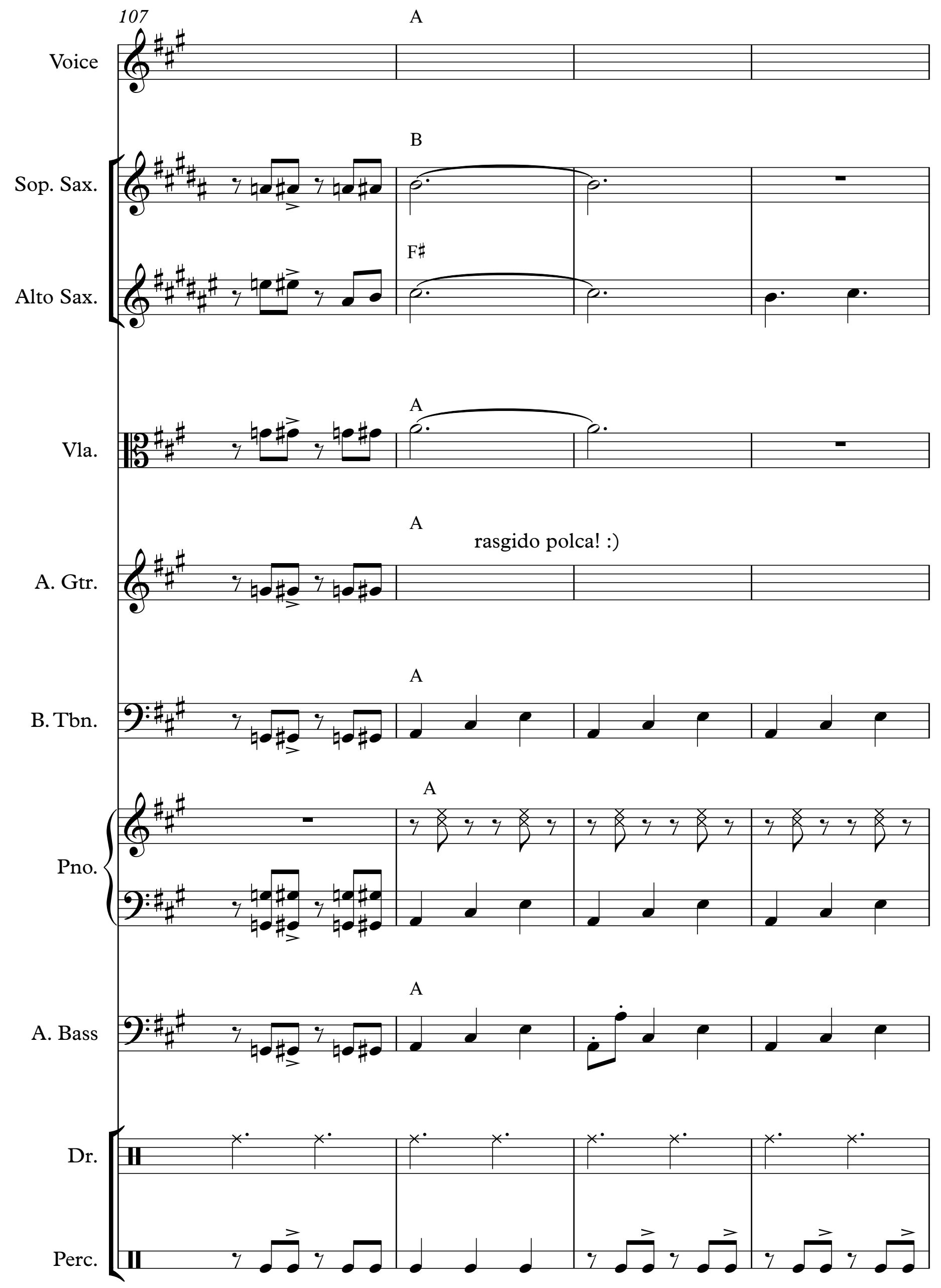




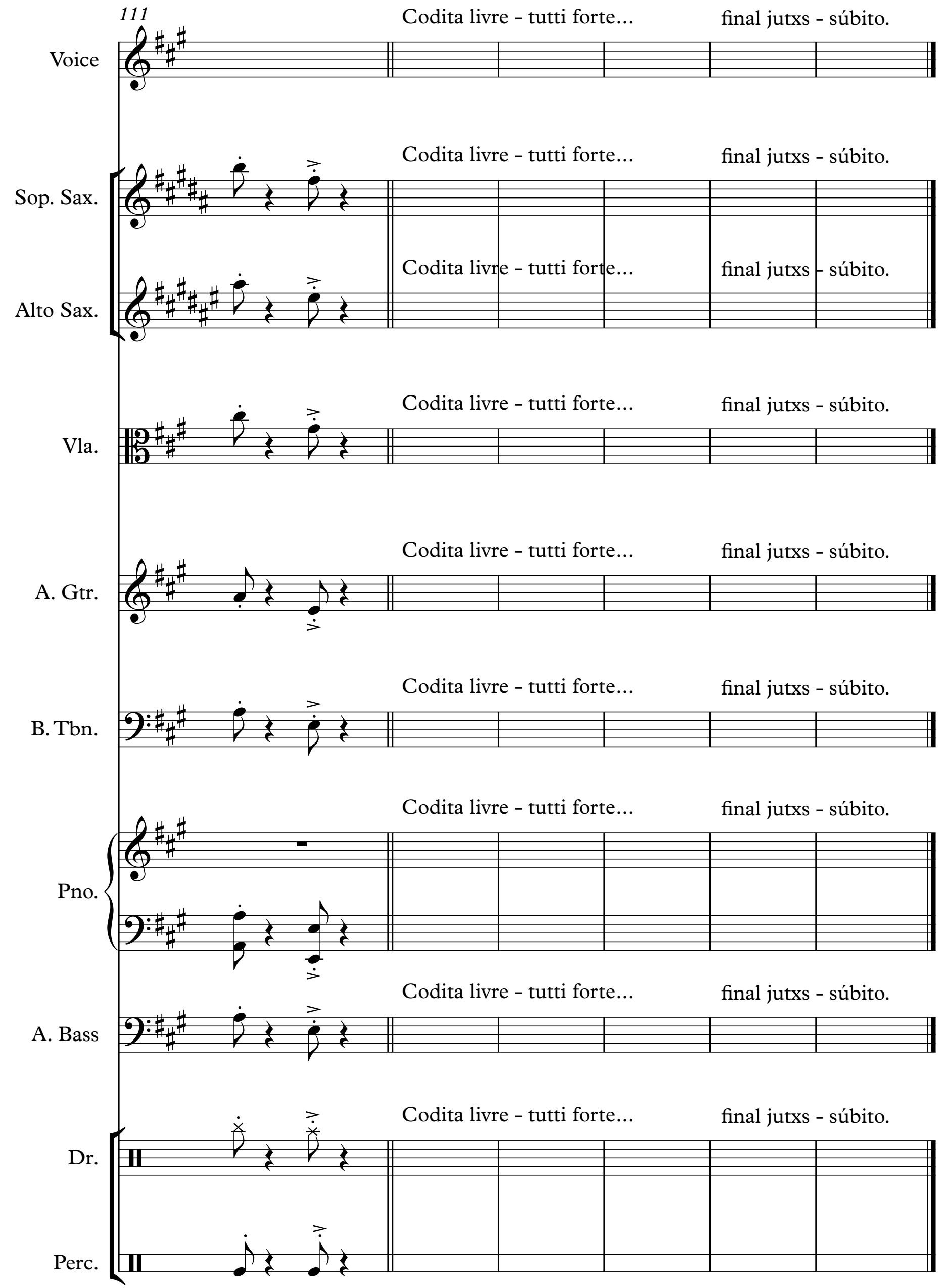


APÊNDICE C. GRADE DA MÚSICA LUCIA PURAHEI PARA A ORQUESTRA ERRANTE E AMIGOS DO PARAGUAY 


\section{Lucia Purahei}

Orquestra Errante
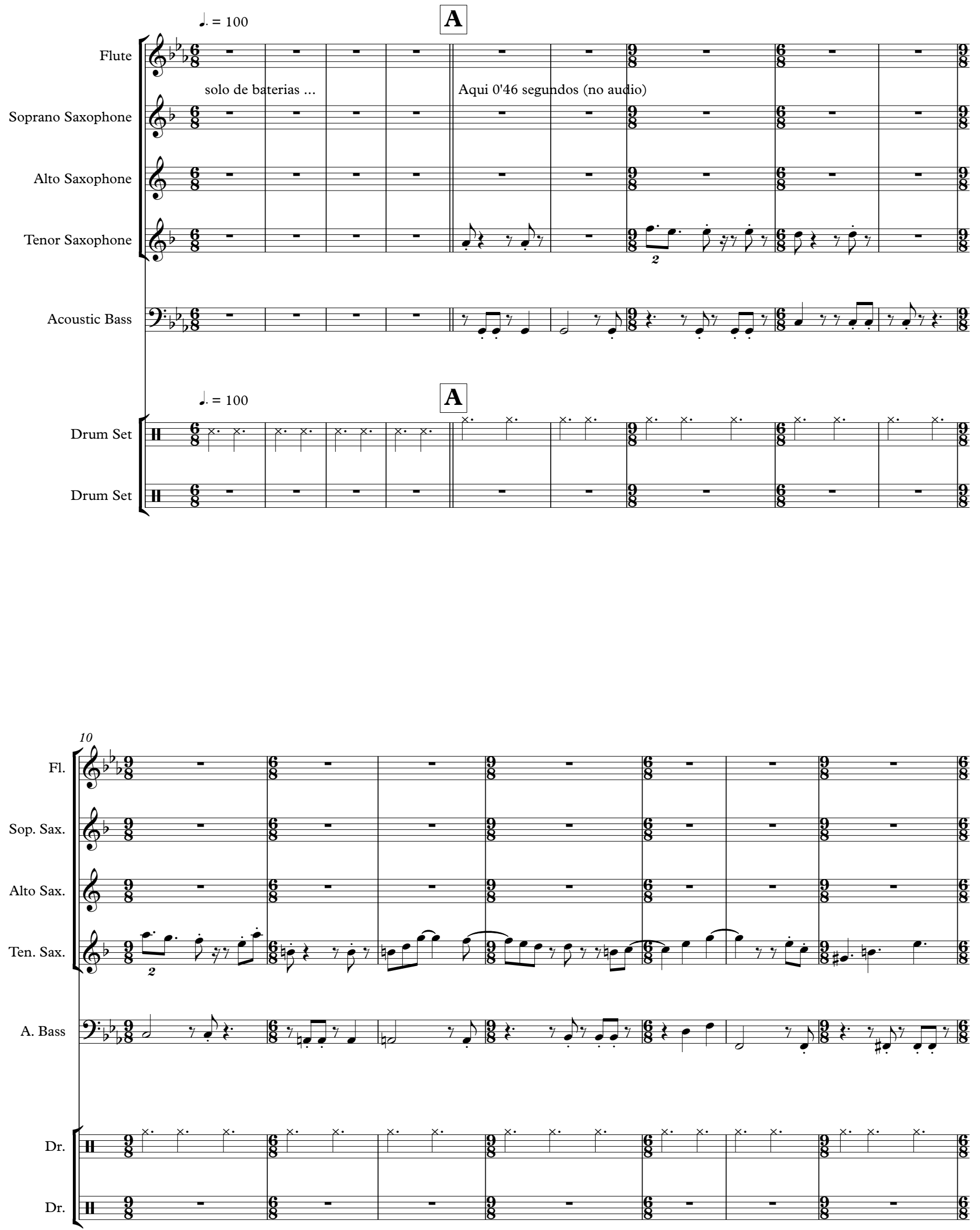

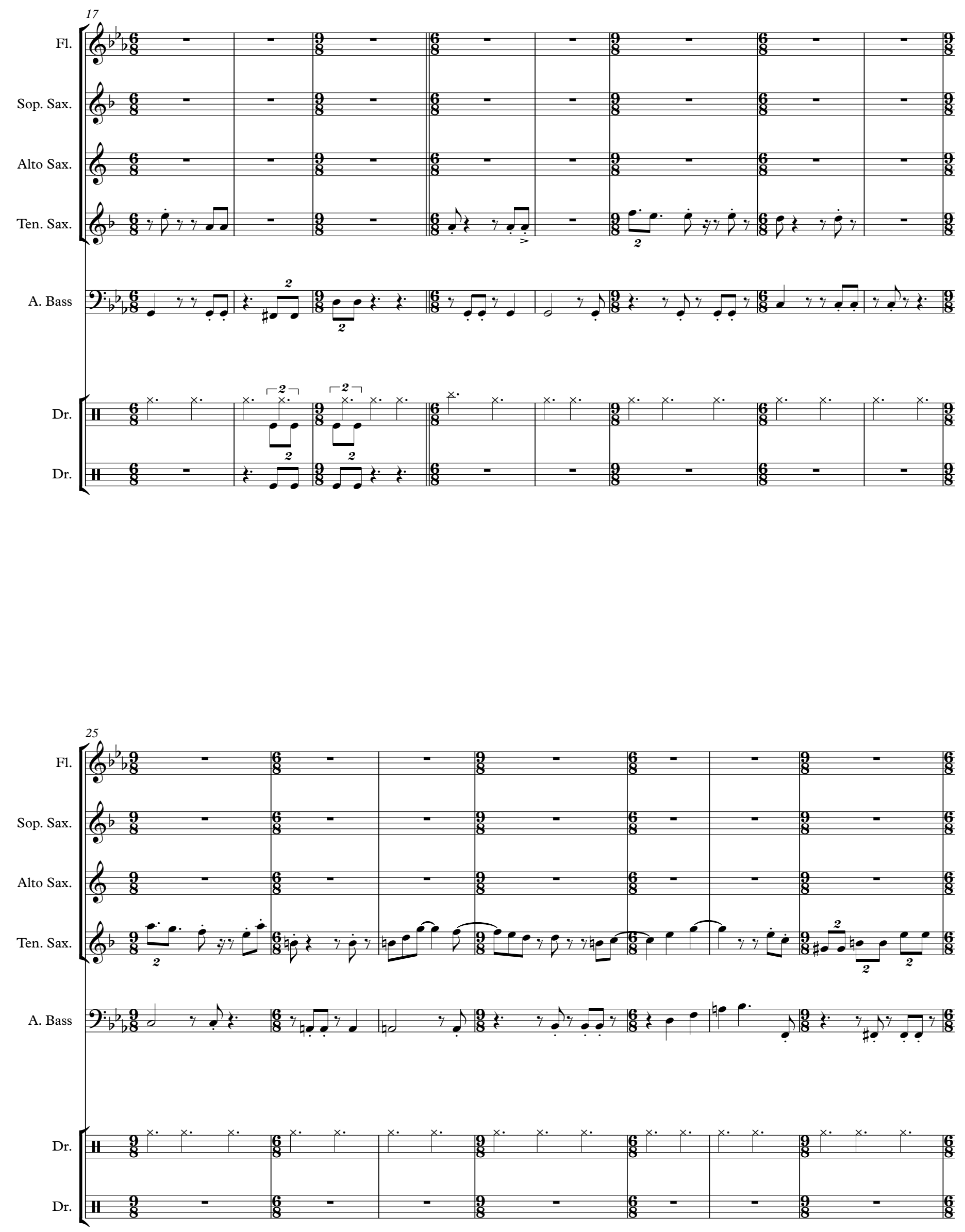

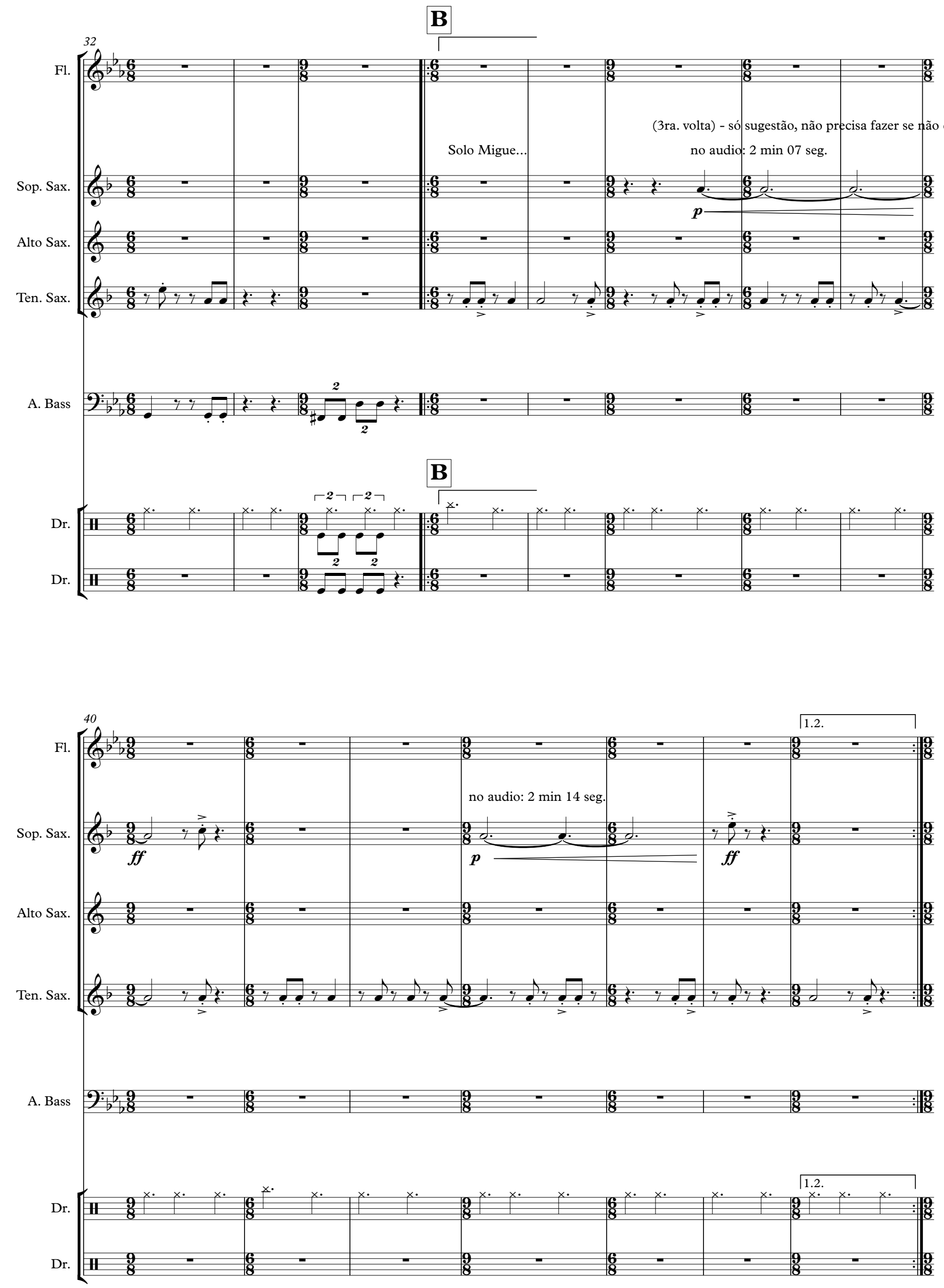

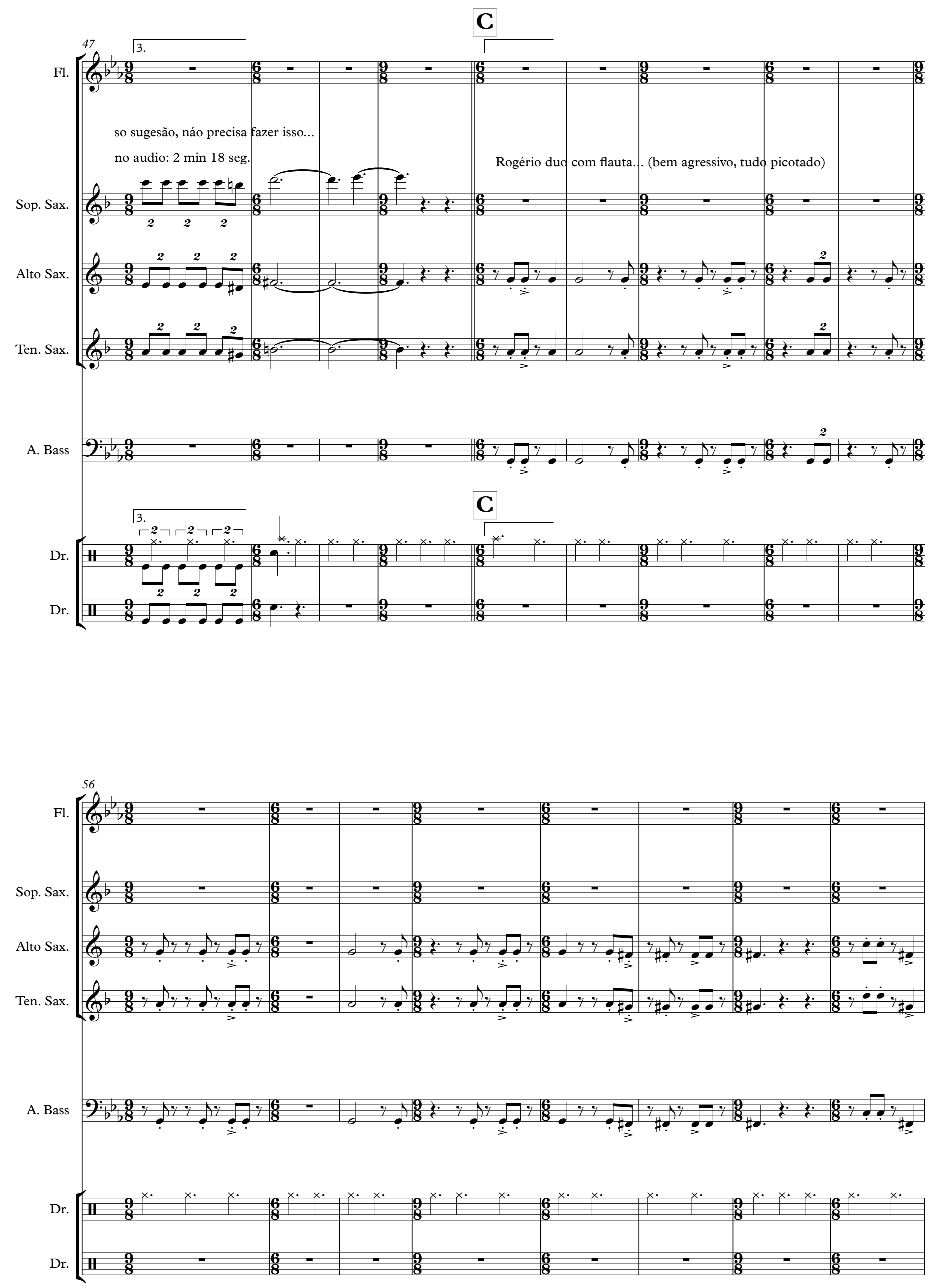

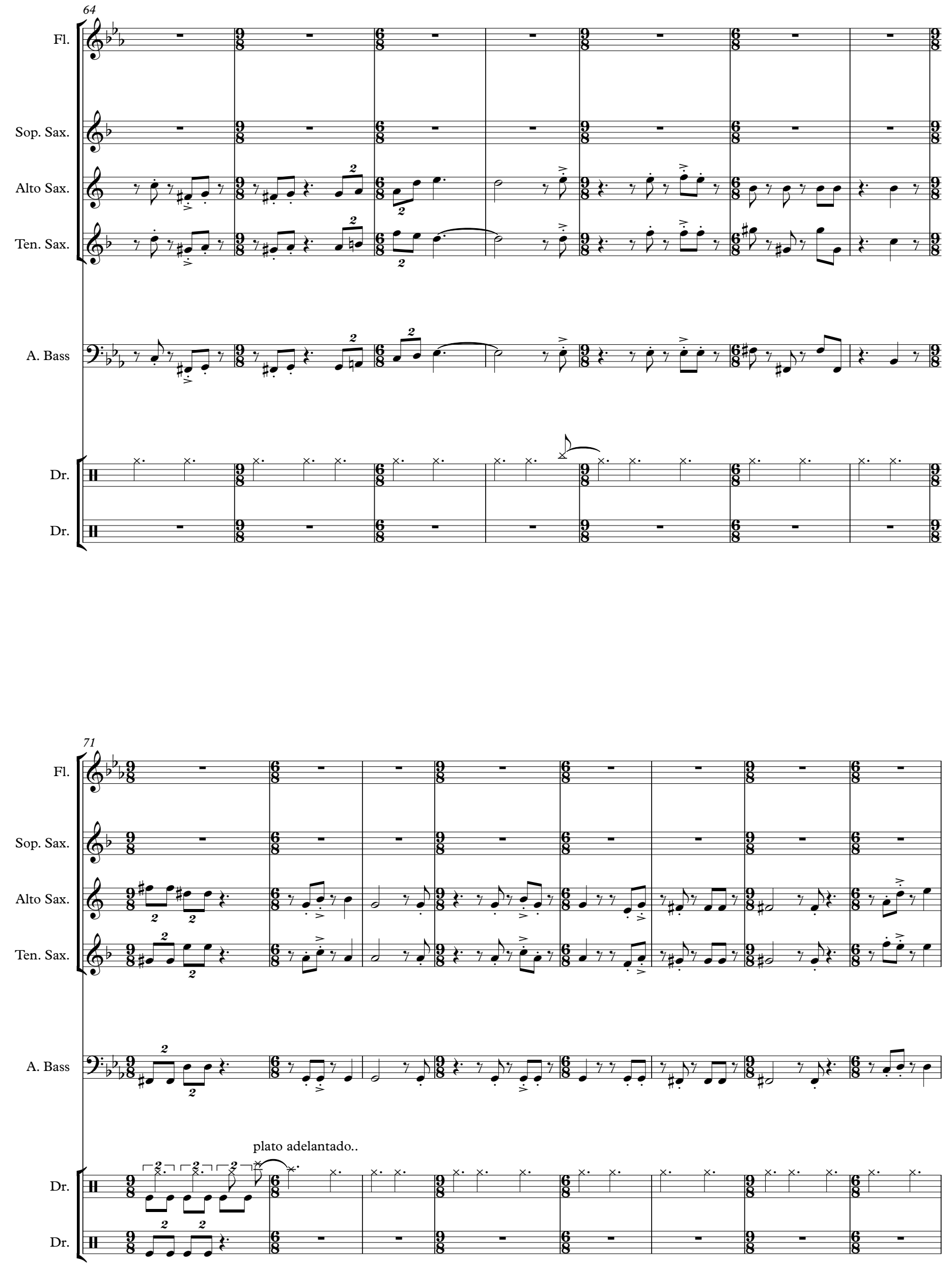


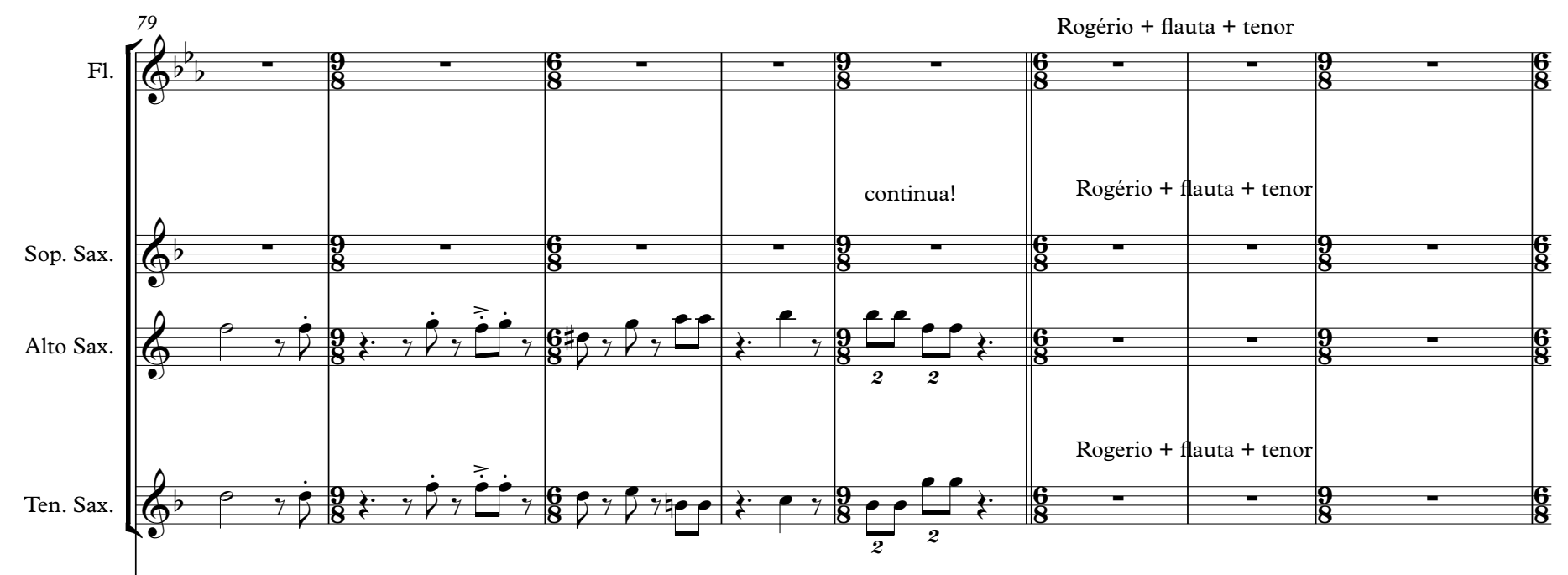

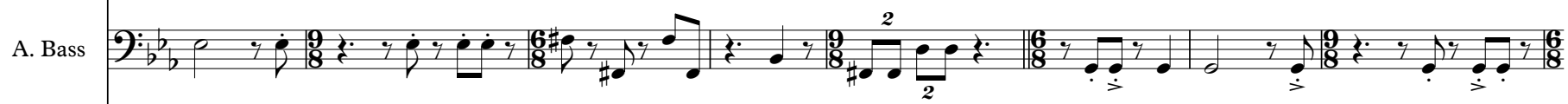
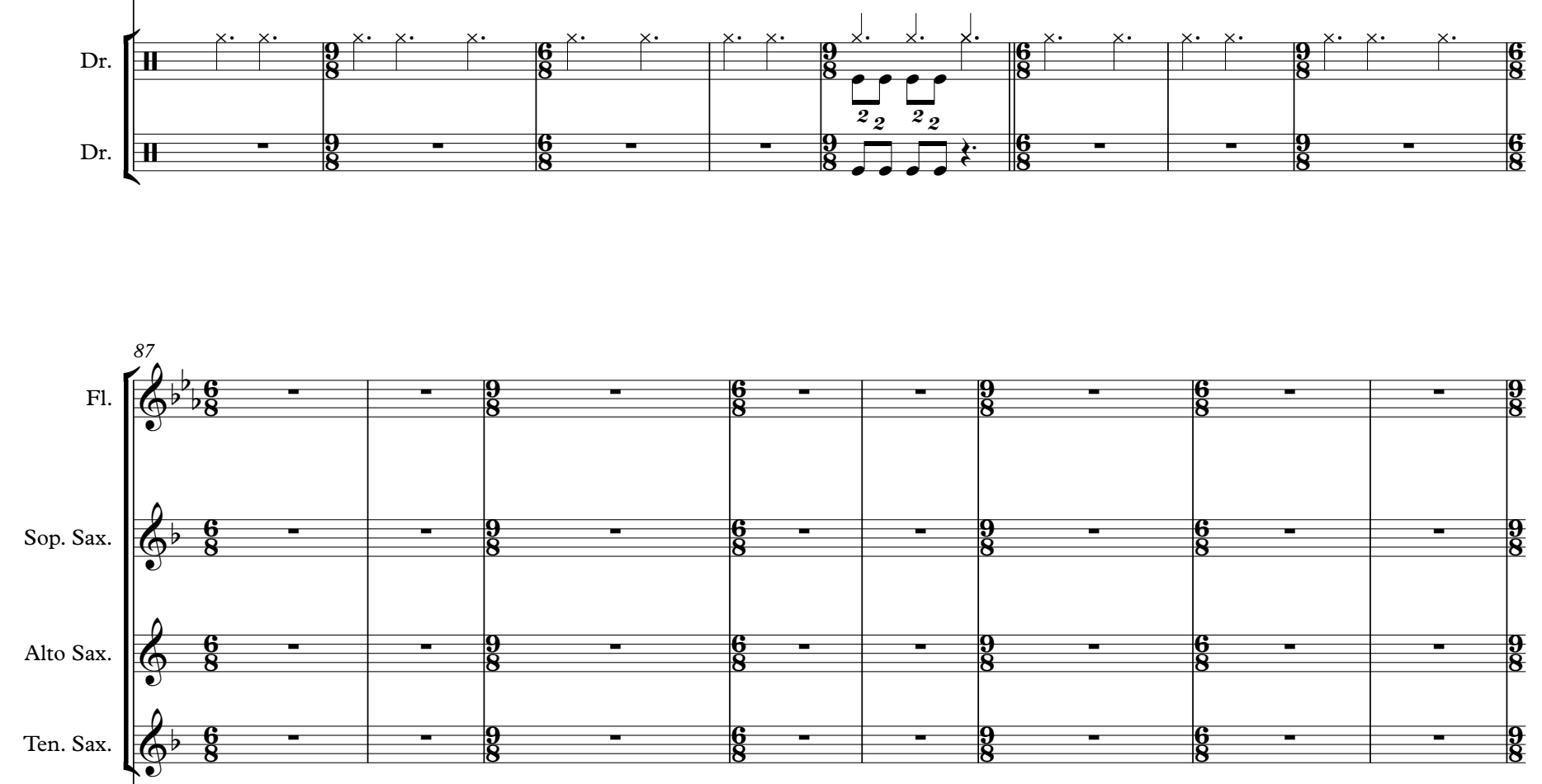

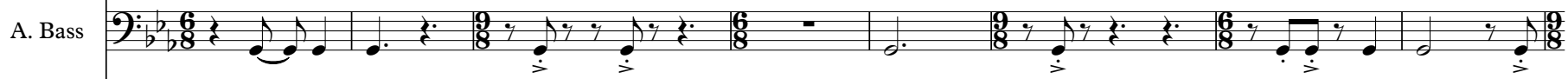

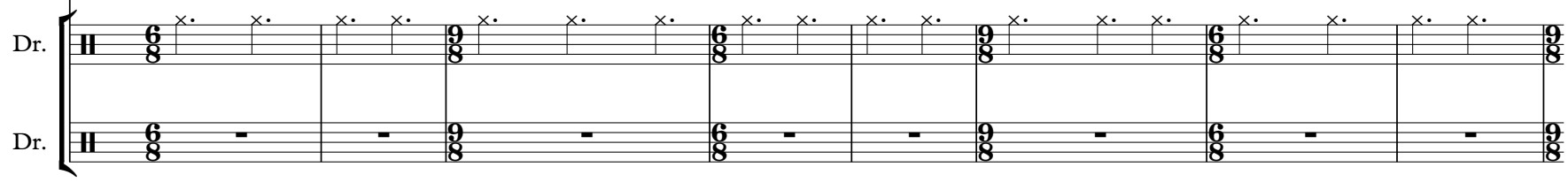


D
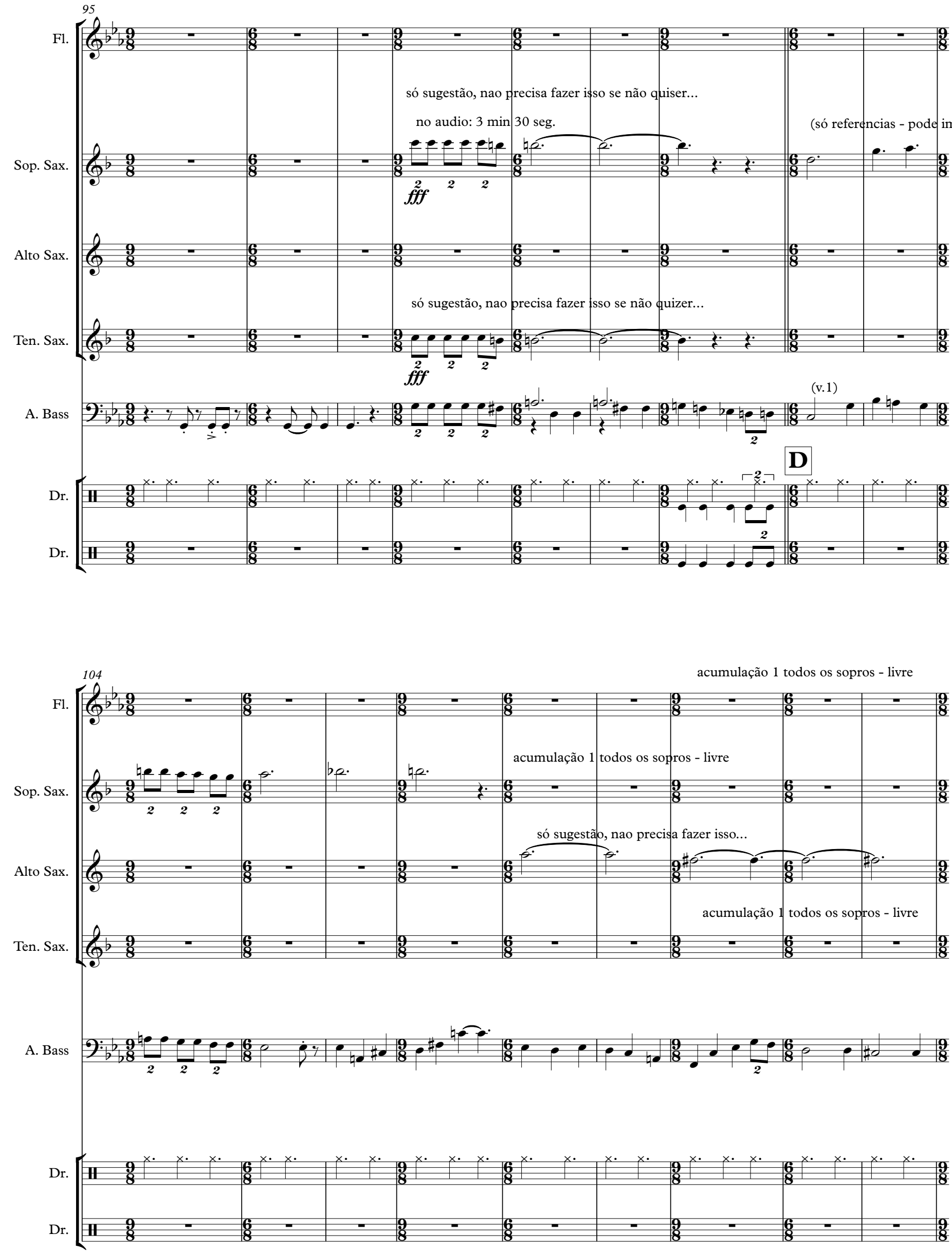


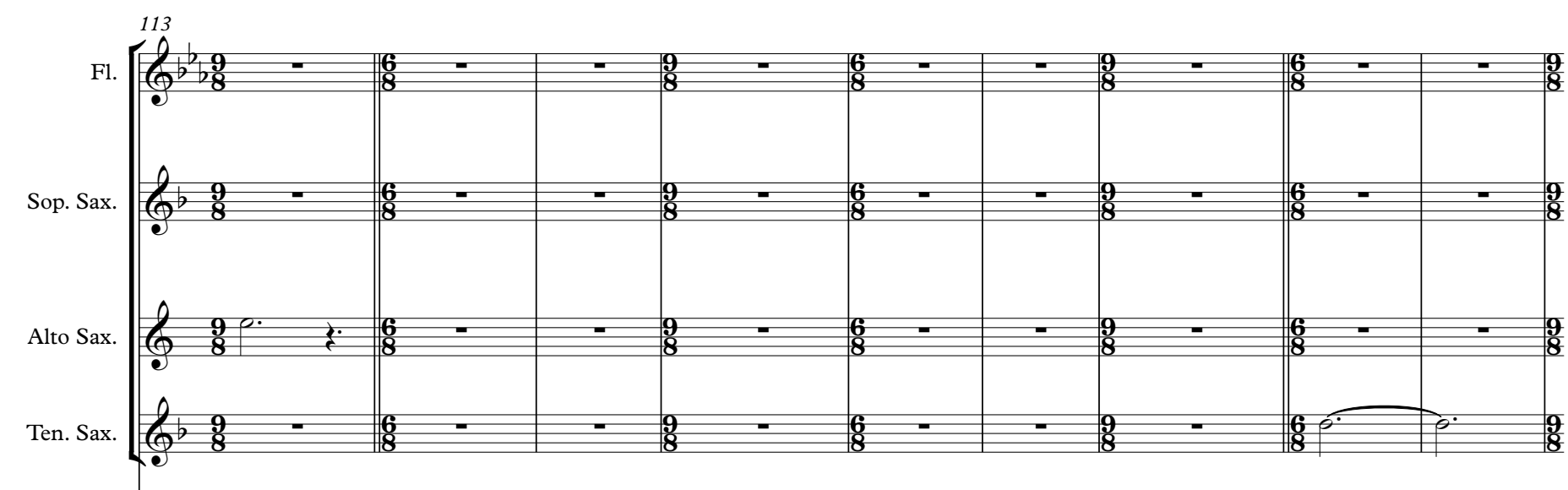

(v.2)

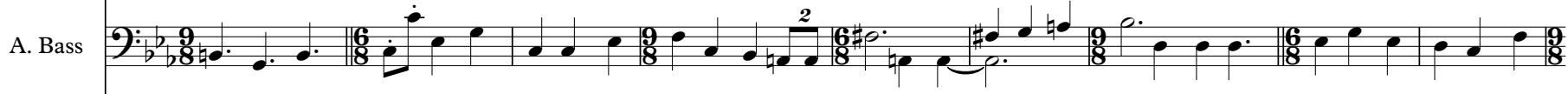
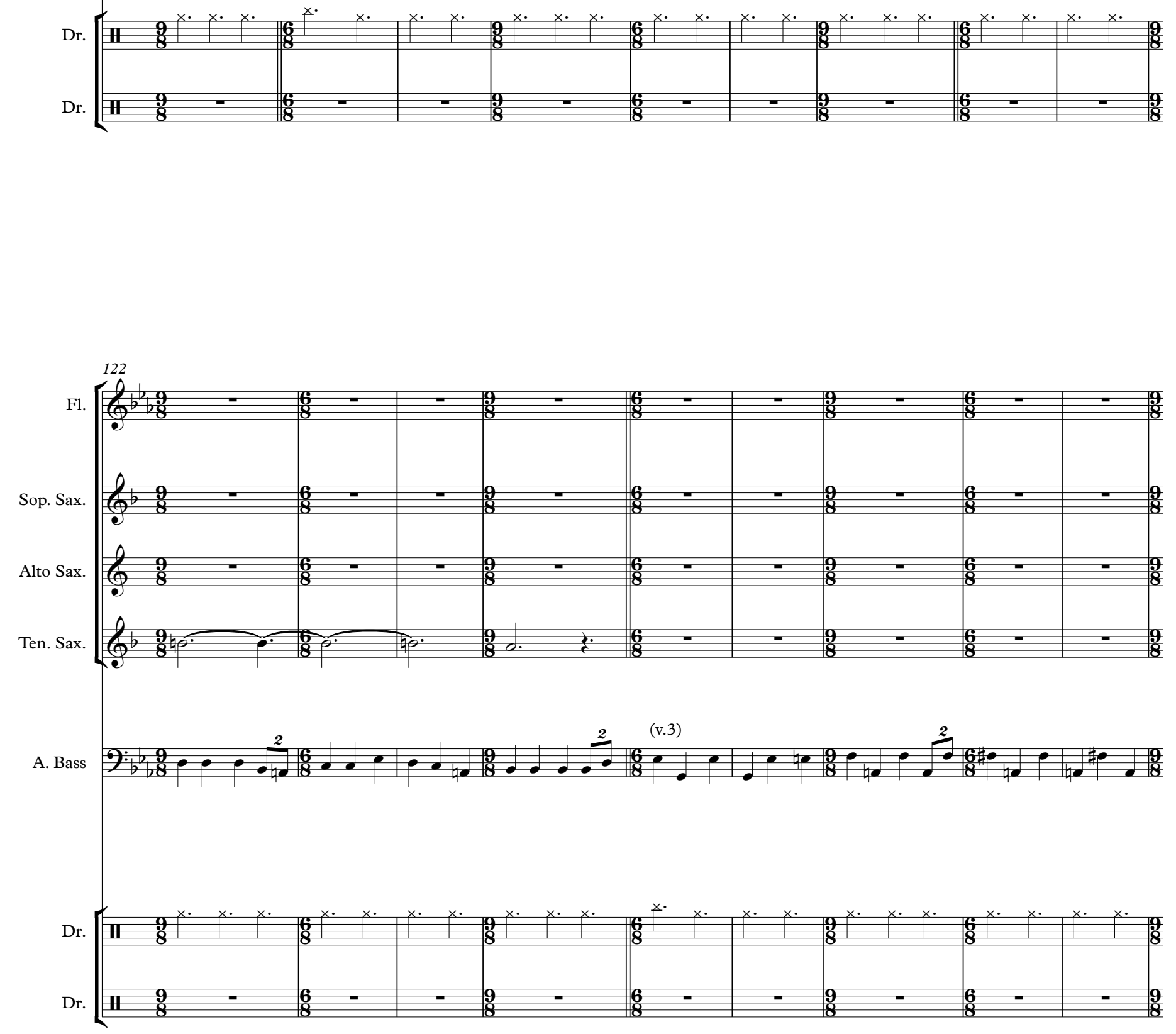


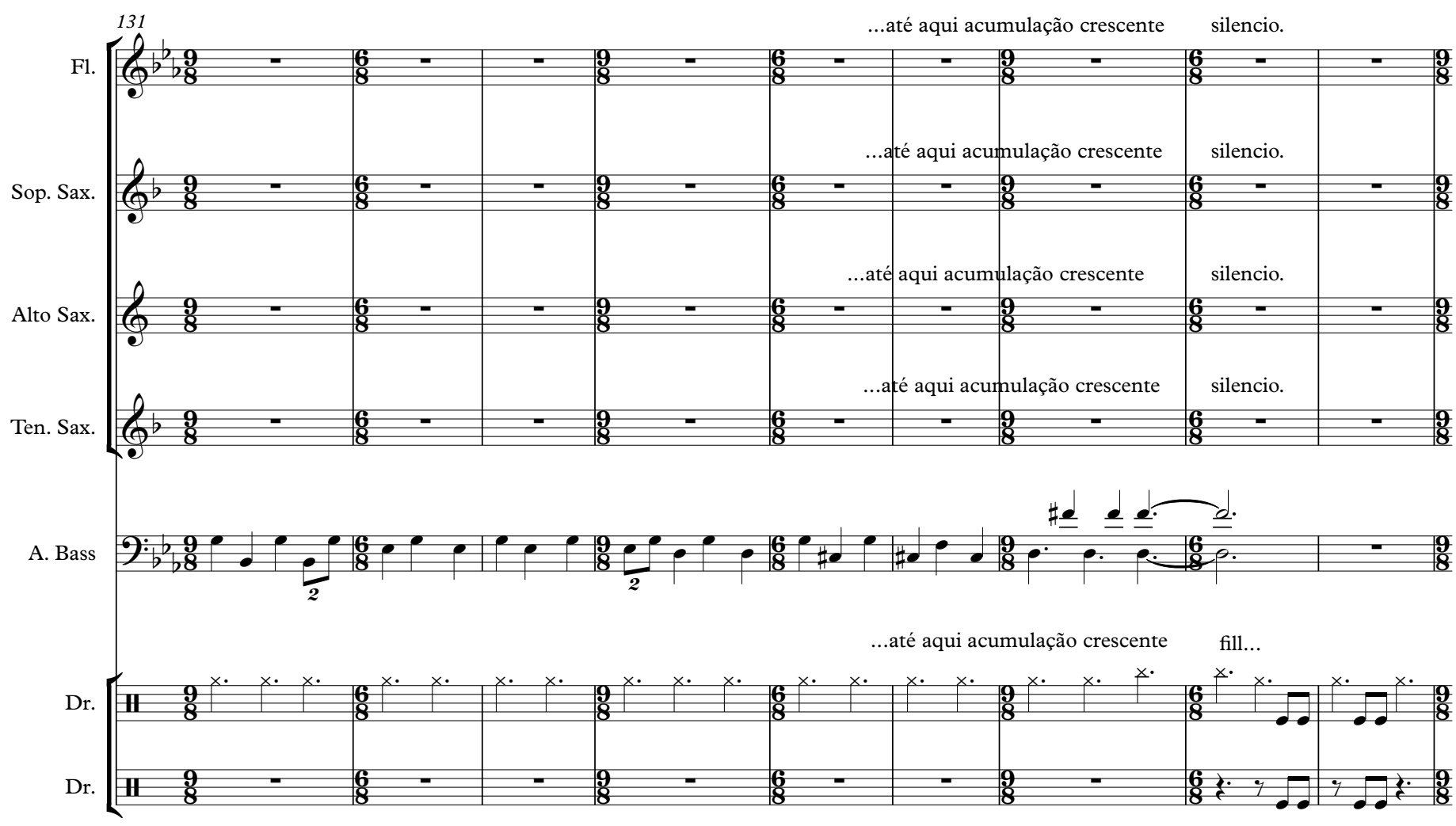

E

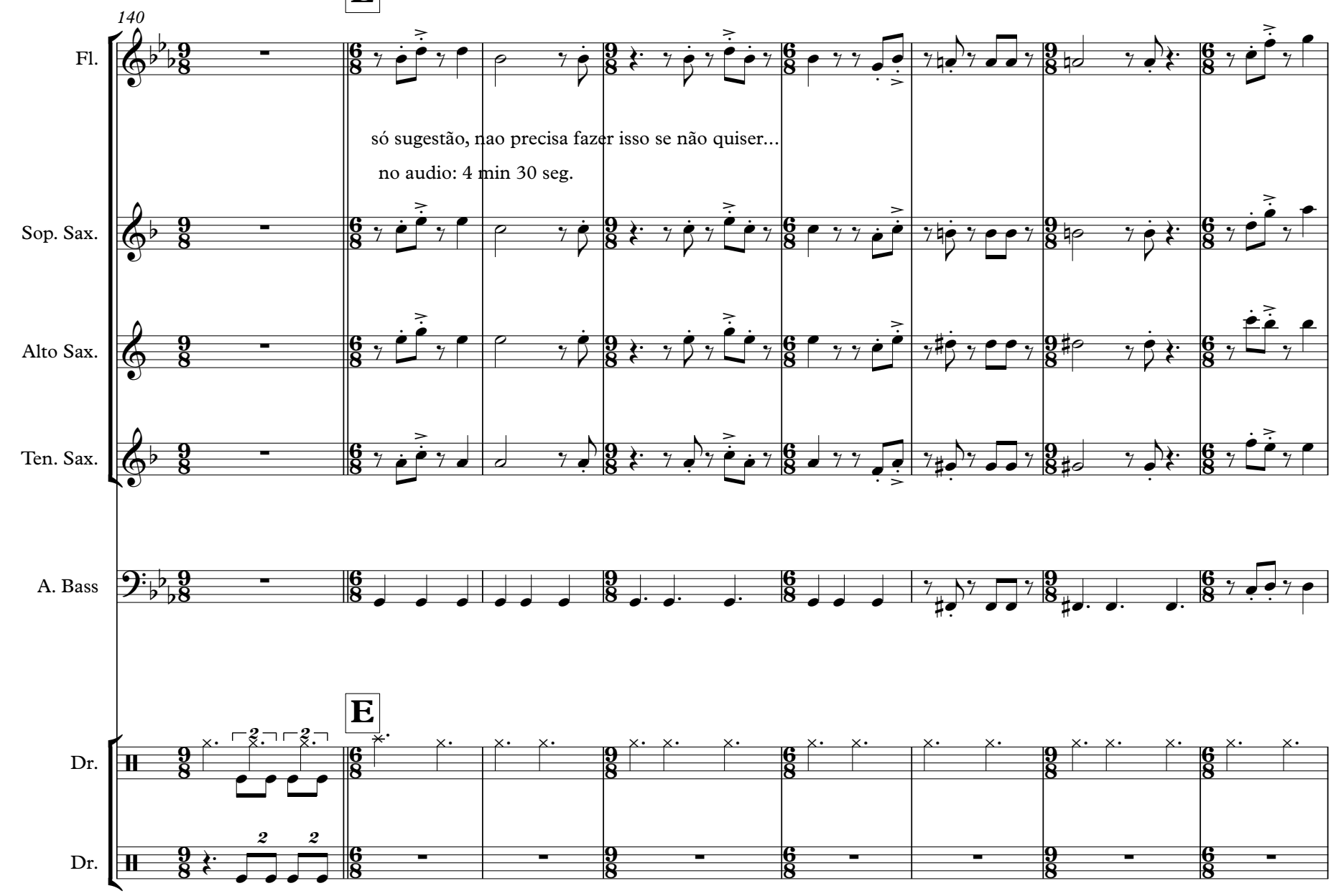


F

só sugestão... pode fazer outra coisa...
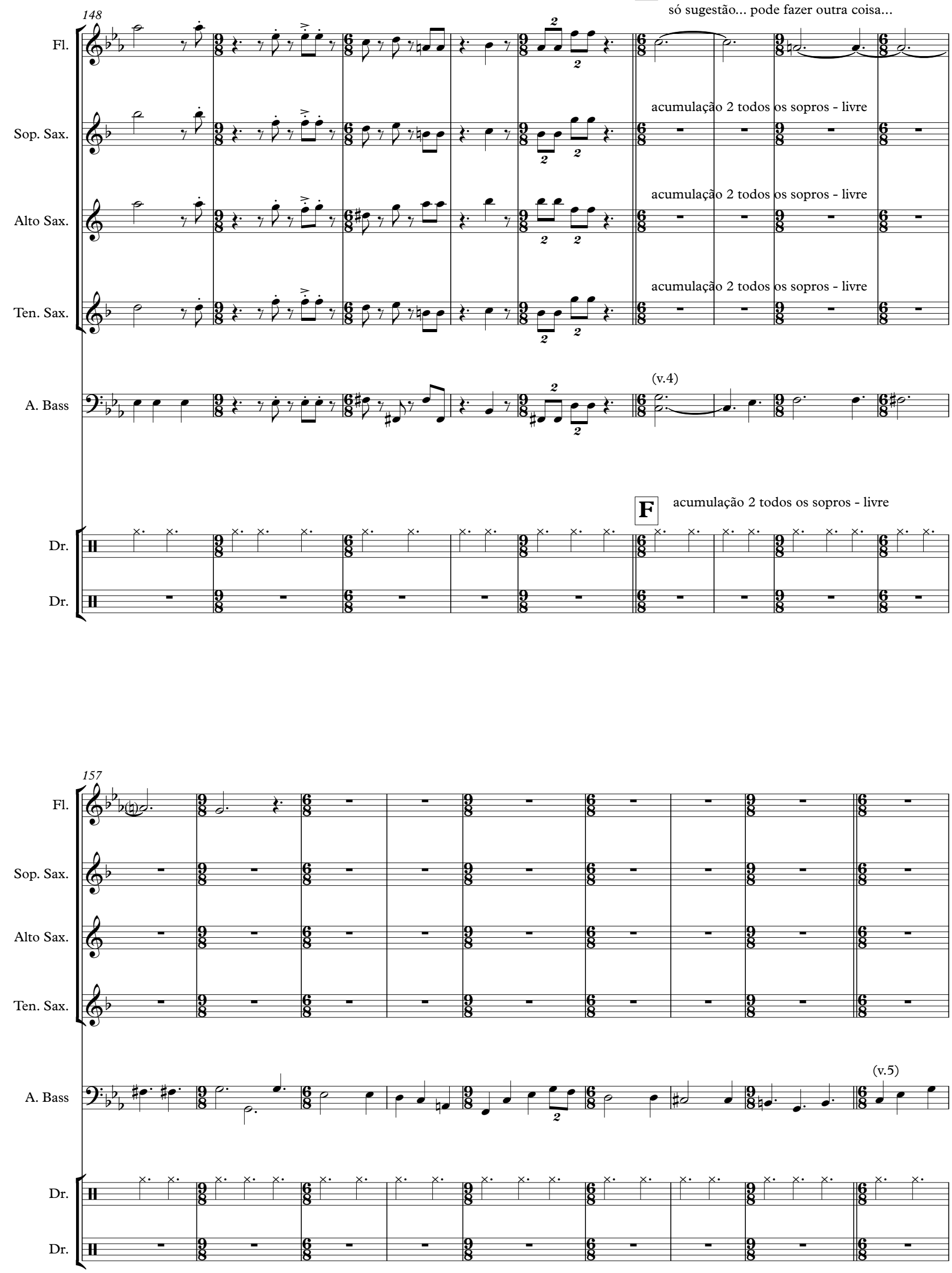


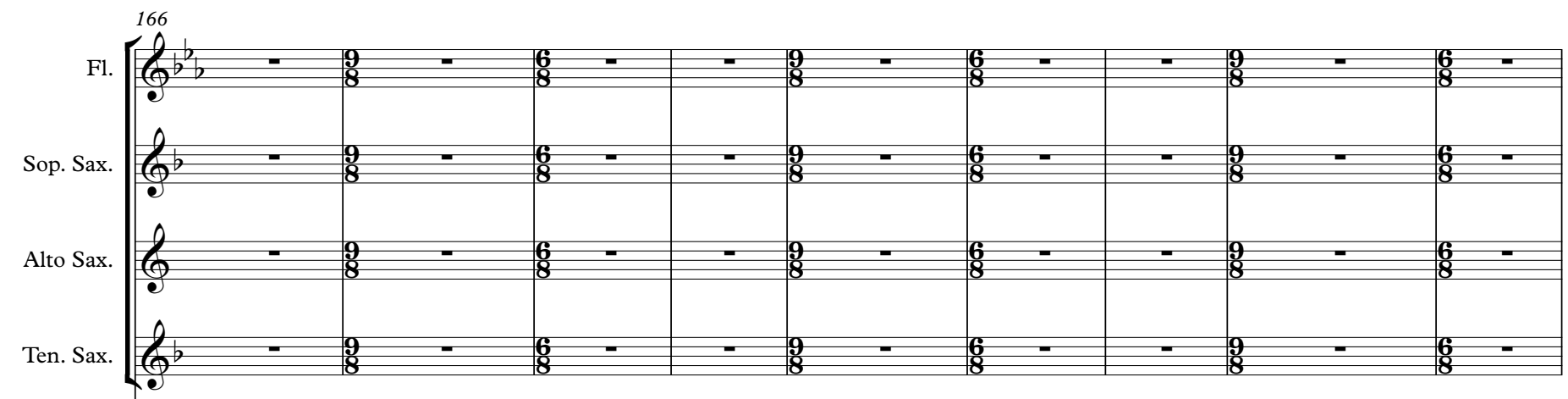

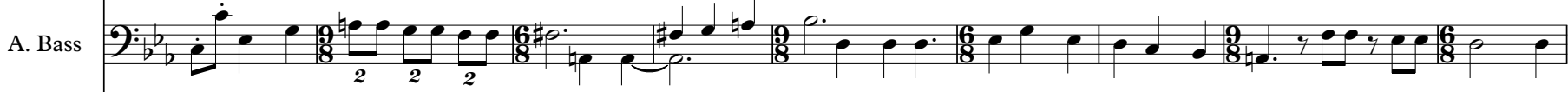
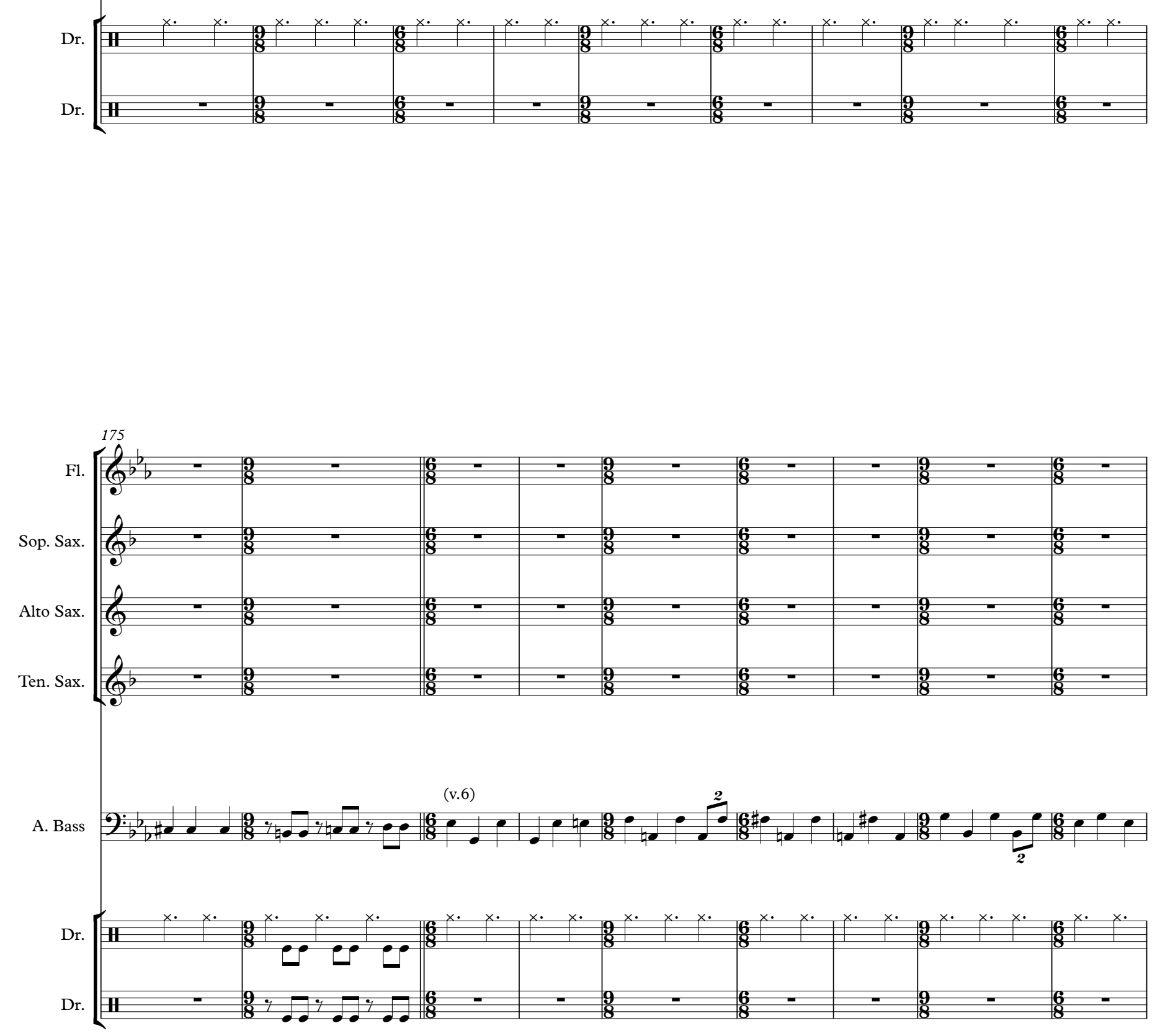


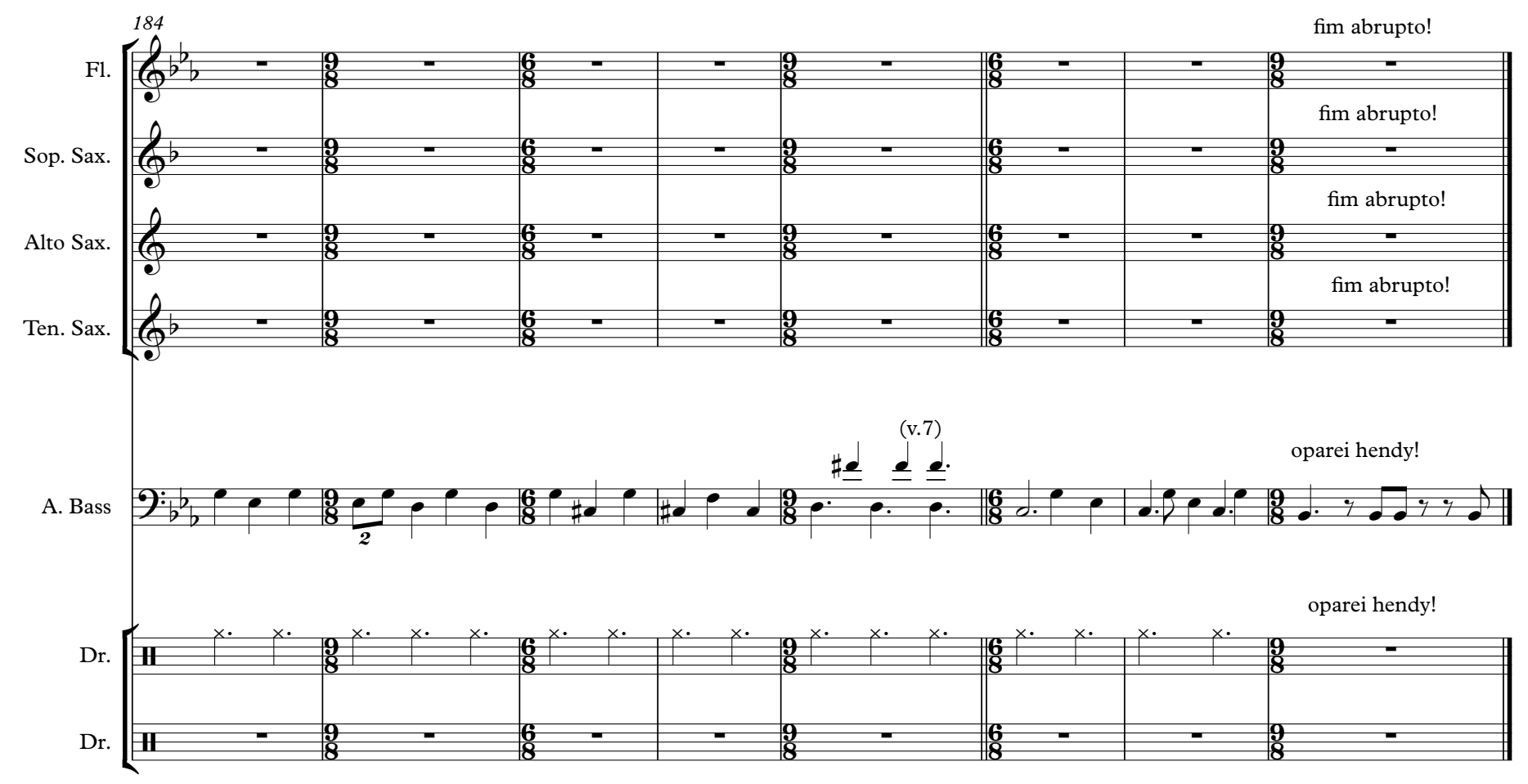


ANEXO A. ARTIGO: APONTAMENTOS SOBRE NARRATIVA ORAL, IDENTIDADE, MACHISMOS E FEMINISMOS NO COMPUESTO MATEO GAMARRA 



\section{SUMÁRIO}

Identidade e diferença na canção latino-americana: uma apresentação

Júlio César Suzuki e Valterlei Borges de Araújo

Caetano Veloso e a canção hispano-americana: tradição e renovação em Fina estampa

Cláudia Neiva de Matos

Agora vou mudar minha conduta: poesia como falamos, poesia como somos

Ênio Bernardes de Andrade

A pluralidade una de José Miguel Wisnik

Ivan de Bruyn Ferraz

Ambivalência do conceito de hibridismo na canção latino-americana: a cultura contemporânea entre paradigmas de aderência e ruptura

João Vicente Ribas

Rasuras no fandom em \#AnittalsOverParty: proposta para uma sistematização dos afetos na ruptura de coerência expressiva da cantora no Twitter

Jonas Pilz

"Canta Pernambuco": as "identidades" nas canções de Deusdete Ferro

Marília Paula dos Santos

Audio-políticas y bio-políticas de las músicas afrodiaspóricas contemporáneas en Colombia

Mateo Pazos Cárdenas

Cantando com narcos: corridos, narcocultura e sua expansão no continente 145 Mateus Fernandes de Lima

Apontamentos sobre narrativa oral, identidade, machismos e feminismos no compuesto Mateo Gamarra

Miguel Eduardo Diaz Antar e Yonara Dantas de Oliveira

"A minha última canção": a maturidade na obra recente de Chico Buarque 180 Sérgio Bento 


\title{
APONTAMENTOS SOBRE NARRATIVA ORAL, IDENTIDADE, MACHISMOS E FEMINISMOS NO COMPUESTO MATEO GAMARRA
}

\author{
Miguel Eduardo Diaz Antar \\ Universidade de São Paulo \\ Doutorando no Departamento de Música da Escola de Comunicações e Artes \\ Agência de fomento: FAPESP (processo n²017/09285-9) \\ miguedz5@gmail.com
}

\section{Yonara Dantas de Oliveira \\ Universidade de São Paulo}

Pós-Doutoranda no Departamento de Música da Escola de Comunicações e Artes

yoyodantas@gmail.com

Resumo: a partir do estudo da canção paraguaia Mateo Gamarra, que pertence ao repertório de música popular tradicional, depreendemos aspectos históricos, políticos e sociais presentes nessa canção. A sua relevância no imaginário paraguaio revela mecanismos particulares de construção identitária do povo guarani, em especial no que se refere à figura feminina.

Palavras-chaves: música popular; memória coletiva; feminismo; polca paraguaia; Paraguai.

Resumen: a partir del estudio de la canción paraguaya Mateo Gamarra, que pertenece al repertorio de música popular tradicional, inferimos aspectos históricos, políticos y sociales presentes en esa canción. Su relevancia en el imaginario paraguayo revela mecanismos particulares de construcción identitaria del pueblo guaraní, en especial en lo que se refiere a la figura femenina.

Palabras-clave: música popular; memoria colectiva; feminismo; polca paraguaya; Paraguay.

\section{Introdução}

No Paraguay ${ }^{77}$, as canções que se dedicam ao registro de fatos verídicos são nomeadas compuestos. Os compuestos mais antigos que se tem referência datam da primeira década do século XX e são considerados um importante meio de transmissão de acontecimentos marcantes na sociedade. Para o pesquisador Florentín Giménez (1997) o compuesto aparece como um modo de crônicas "depois da Guerra

\footnotetext{
${ }^{77}$ Optamos por grafar os nomes de países, estados e cidades no seu idioma original.
} 
Grande $^{78}[1864-1870]$, para suprir as necessidades de comunicação das cidades. Sua modalidade artística, exclusivamente de caráter narrativo, relata fatos que comoveram a população" (GIMÉNEZ, 1997, p.262 - tradução nossa ${ }^{79}$ ). Os compuestos são cantados nos diversos ritmos paraguaios como polca, guarânia e rasguido doble.

Sem data precisa de composição, o compuesto Mateo Gamarra ${ }^{80}$ surge na primeira metade do século XX e relata um assassinato ocorrido na década 1930. A letra da canção está em jopará - dialeto paraguaio que mistura uso de palavras em guarani com palavras em espanhol. Essa particularidade linguística se gestou no Paraguay a partir de um certo desapego à língua dos conquistadores, posicionando-o "as margens da hispanidade", pois em nenhum outro país da América Latina "existe, junto ao castelhano, uma segunda língua de igual importância" (DIETRICH apud PENNER et al., 2012, p.10 - tradução nossa ${ }^{81}$ ). O pesquisador Wolf Dietrich, no prefácio ao livro El descubrimiento del castellano paraguayo a través del guaraní (2012), escreve:

[O jopará] é a denominação abreviada da situação linguística complexa do país a respeito do guarani falado, que não se pode imaginar sem a presença do castelhano, e do castelhano peculiar, que não se explica sem as interferências do guarani (DIETRICH apud PENNER et al., 2012, p.10 - tradução nossa ${ }^{82}$ ).

Para o presente trabalho traduzimos a letra do compuesto Mateo Gamarra ao português e extraímos apontamentos sobre memória e identidade, machismos e feminismos, a partir da sua análise. Também observamos elementos musicais que nos ajudam na construção de nosso argumento a respeito da obra.

\footnotetext{
${ }^{78}$ A Guerra da Tríplice Aliança (1864-1870) também é nomeada por diversos pesquisadores como Guerra Grande, Guerra del 70', Guerra Guazú e/ou Guerra do Paraguai.

${ }^{79}$ No original: después de la Guerra Grande, para suplir a las necesidades de comunicación ciudadana. Su modalidad artística, que fue exclusivamente de carácter narrativo, relata aquellos hechos que conmovieron a la población (GIMÉNEZ, 1997, p.262).

${ }^{80}$ Ao longo deste artigo, acionaremos como referência a interpretação do compuesto Mateo Gamarra pelo Duo Quintana-Escalante. O áudio pode ser acessado no seguinte endereço eletrônico: https://www.youtube.com/watch?v=FBQchiFkKpo. Acesso em: 18 dez. 2018. A transcrição da letra está disponível (no original e em português) como anexo neste artigo.

${ }^{81}$ No original: En los márgenes de la hispanidad (...). [En ninguno de esos países] existe, junto al castellano, una segunda lengua de igual importancia. (DIETRICH apud PENNER et al. 2012, p.10).

${ }^{82}$ No original: es la denominación abreviada de la situación lingüística compleja del país con respecto al guaraní hablado, que no se puede imaginar sin la presencia del castellano, y del castellano peculiar, que no se explica sin las interferencias del guaraní (DIETRICH apud PENNER et al., 2012, p.10).
} 


\section{I - Pano de fundo para a história do crime}

Na polca paraguaia Mateo Gamarra está retratada a discussão de um casal Mateo Gamarra e Delfina Servín -, durante uma festa na cidade de Puerto Guarani, Paraguay. Em decorrência dessa discussão, Delfina disparou cinco tiros contra seu marido, Mateo, que faleceu. A letra do compuesto descreve com detalhes a história. As primeiras estrofes indicam lugar, data e hora do ocorrido. O dia do mês e da semana estão explicitados, mas não o ano em que ocorreu o fato. Embora artigos de jornais ${ }^{83}$ indiquem que o crime aconteceu em 1931, analisamos os dados mencionados na letra da canção onde, explicitamente se diz: "quarta-feira, dia 12 de outubro, por volta do meio dia", e concluímos que o evento ocorreu no ano de 1932, ano bissexto, em que o dia 12 de outubro caiu numa quarta-feira.

Cremos possível que a confusão a respeito da data do crime esteja relacionada com o tenso período histórico que sobreveio ao Paraguay naqueles anos. Em setembro de 1932 iniciava a segunda maior contenda bélica em território paraguaio, a Guerra del Chaco (1932-1935), entre Bolivia e Paraguay. A guerra deixou o Paraguay ainda mais pobre e com aproximadamente 45 mil mortos ${ }^{84}$. Embora as hostilidades tenham finalizado em junho de 1935, o tratado para acabar a guerra só foi firmado em julho 1938 e apenas em abril de 2009 - 74 anos depois - foi firmado o acordo ${ }^{85}$ definitivo de demarcação de limites, assinado pelos então presidentes Evo Morales, da Bolivia, e Fernando Lugo, do Paraguay.

Após a Guerra del Chaco (1932-1935), o Paraguay ainda atravessou uma guerra civil (1947) na qual o Estado massacrou camponeses contrários às políticas de governo,

\footnotetext{
${ }^{83}$ No jornal paraguaio ABC Color, em edição de dia 12 de outubro de 2012, foi publicada uma reportagem especial sobre o crime pelos 81 anos do evento, sendo indicado como data o dia 12 de outubro de 1931. Disponível em: http://www.abc.com.py/especiales/fin-de-semana/historia-de-uncrimen-que-se-hizo-leyenda-462673.html. Acesso em: 18 dez. 2018.

Aconteceu o mesmo erro na citação da data na publicação do dia 13 de outubro de 2017 pelo jornal paraguaio Última Hora, em uma reportagem especial pelos "86 anos" do crime. Disponível em: https://www.ultimahora.com/la-polca-mateo-gamarra-una-historia-veridica-que-cumplio-86-anosn1112958.html. Acesso em: 18 dez. 2018.

${ }^{84} \mathrm{~A}$ barbárie da guerra também cegou a vida de aproximadamente 60 mil bolivianos.

85 A celebração do acordo foi publicada por vários jornais como BBC: https://www.bbc.com/mundo/america_latina/2009/04/090428_2135_paz_bolivia_paraguay; e Última Hora: https://www.ultimahora.com/paraguay-y-bolivia-firman-hoy-acuerdo-definitivo-limitesn216763.html. Acesso em: 18 dez. 2018.
} 
acusando-os de comunistas. O Partido Colorado consolidou sua hegemonia ${ }^{86}$ e levou ao poder o ditador Alfredo Stroessner que se manteve até 1989. Durante todos esses anos de terror e obscuridade, o trabalho musical no Paraguay basicamente se limitou às apresentações ao vivo em festas privadas ou nas comunidades. Poucos/as músicos/musicistas tinham acesso a equipamentos e estrutura de gravação.

\section{II - Da criação individual à memória coletiva}

Durante décadas o compuesto Mateo Gamarra foi interpretado pelos mais variados artistas, tornando-se parte do repertório de música popular tradicional do Paraguay. E por muitos anos foi considerado de autoria desconhecida. Apenas na década de 1970 ocorre o registro de autoria na Sociedad Argentina de Autores y Compositores de Música (SADAIC), que indica que a letra é de Estanislao Báez e a música, de Eladio Martinez. Embora a instituição paraguaia Autores Paraguayos Asociados (APA) tenha se originado em 1951, durante décadas muitos/as músicos/musicistas realizaram seus registros e gravações musicais na Argentina ${ }^{87}$, onde se tinha acesso a uma melhor estrutura técnica. No Paraguay, o aprimoramento da qualidade dos estúdios de gravação acontece apenas depois da queda do ditador Alfredo Stroessner.

Em reportagens de jornais paraguaios, dedicadas à rememoração do episódio registrado no compuesto Mateo Gamarra, encontramos o relato do engenheiro Carlos Vergara Báez, neto de Estanislao Báez, que reforça a autoria da música e afirma que a história narrada pelo seu avô é um fato verídico. Na reportagem do jornal $A B C$ Color (2012) Carlos relata:

\footnotetext{
${ }^{86}$ O Partido Colorado se manteve no comando do país de 1947 a 2008, ano em que Fernando Lugo foi eleito presidente. Em 2012 o parlamento paraguaio, num processo que durou apenas 24 horas, decretou a destituição do presidente Lugo por "mal desempenho". Esse processo de impeachment foi considerado tão grave que o país foi suspenso do Mercosul até a próxima eleição. O vice-presidente Federico Franco assumiu o governo de transição. Na eleição seguinte, e desde 2013, voltou ao poder o Partido Colorado.

${ }^{87}$ Considerando o levantamento realizado por Szarán (1999) a respeito da fonografia no Paraguay, observamos que a partir da primeira década do século XX já se iniciam as gravações de música paraguaya na Argentina e no Brasil. Inúmeros artistas paraguaios gravaram suas músicas no exterior. No Paraguay somente a partir da década de 1960 - 1970 começam a funcionar alguns selos de gravação, "que editam material prensado no exterior, dada a inexistência de uma empresa [nacional] de prensado" (SZARAN, 1999, p.206).
} 
Ele (Eslanislao Báez) era ferroviário e responsável pelas fiscalizações, por isso viajava a diferentes lugares do país e justo chegou a Puerto Guarani quando as pessoas ainda estavam chocadas com o que ocorrera (VERGARA apud DIAZ, 2012, online - tradução nossa ${ }^{88}$ ).

Em outras reportagens, no entanto, se questiona a veracidade do acontecimento dada a ausência de documentação. A precariedade nos registros dessa época pode ser o motivo dos questionamentos. De toda forma, a história permanece presente no imaginário paraguaio. Desde a perspectiva musical, o evento se encontra devidamente registrado na memória coletiva compartilhada pelo repertório de música tradicional. Podemos observar isso a partir das inúmeras gravações do compuesto.

O Duo Quintana Escalante - dupla folclórica de grande fama no Paraguay gravou o compuesto em um disco chamando El Dúo De La Simpatia - Dúo QuintanaEscalante y Su Conjunto Paraguayo, sem data de gravação explicitada no álbum. A mesma gravação também se encontra no disco Dúo Quintana Escalante Grandes Exitos: 1 hora de música paraguaya, de 1997.
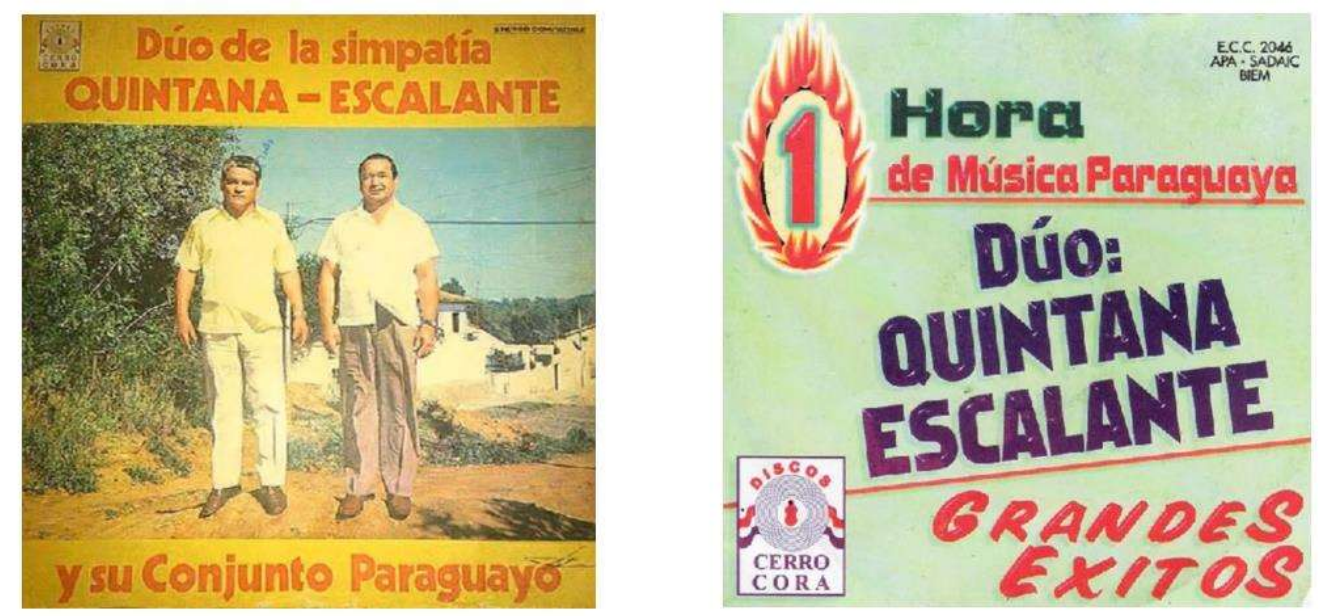

Fig.1: Capas de dois discos do Duo Quintana Escalante onde se encontra a gravação do compuesto Mateo Gamarra.

O Duo Quintana Escalante nasceu em 1950, formado por Valério Quintana (1925-2002), músico argentino, e por Martín Escalante (1925-2013), músico paraguaio.

\footnotetext{
${ }^{88}$ No original: Él (Estanislao Báez) era ferroviario y era responsable de fiscalizaciones, por lo que viajaba a diferentes lugares del país y justo llegó a Puerto Guaraní cuando la gente aún estaba conmocionada por lo que pasó (VERGARA apud DIAZ, 2012, online). Disponível em: http://www.abc.com.py/especiales/fin-de-semana/historia-de-un-crimen-que-se-hizo-leyenda462673.html. Acesso em: 18 dez. 2018.
} 
Alcançaram muita popularidade durante as décadas de 1960 e 1970 e continuaram uma carreira bem-sucedida durante mais de 50 anos, até 2002 , ano de falecimento de Quintana. O duo fez muito sucesso no Paraguay e é considerado referência na música popular tradicional do país. Nos últimos anos de vida, em reconhecimento ao trabalho cultural realizado, o duo foi contemplado com pensões ${ }^{89}$ do Congreso de la Nación Paraguaya.

Como mencionamos, existem controvérsias nos dados a respeito da autoria da obra. A autoria seria de Estanislao Báez e Eladio Martinez? E uma das primeiras gravações e, certamente a mais conhecida, do Duo Quintana Escalante? Não é possível precisar. Em uma nota disponível online, a Asociación Cultural Mandu'ara publicou uma entrevista com Martín Escalante (infelizmente a nota não indica a data da entrevista), na qual se afirma:

O Duo Quintana Escalante, em 1950, recolheu fragmentos do compuesto [Mateo Gamarra] no Puerto Guarani. Já em Asunción, completaram suas estrofes. Em 1957, em Buenos Aires, gravaram a composição que imediatamente se popularizou. Uns anos depois segundo conta Martín Escalante -, um homem humilde, que dizia ser o autor do compuesto, se apresentou na sua casa [na cidade] de San Vicente. Ele pediu parte do lucro de um milhão de guaraníes que a obra tinha dado a [Martín] e Carlos Quintana. [Martín esclarece:] "Acontece que um sobrinho meu lhe disse isso. Eu o enviei para Autores Paraguayos Asociados, APA. Lá, para escapar da sua insistência, o enviaram junto a Eladio Martínez, o compilador da obra. Este, a quem não faltava humor, respondeu que se apoderou da obra e o despediu com um 'máva piko oñemomba'eseta te'onguére' (Quem quer ser dono de um morto?)" (ESCALANTE, 2017, online - tradução nossa ${ }^{90}$ ).

Ainda no sentido da autoria, na reportagem do jornal Última hora (2013) sobre

\footnotetext{
${ }^{89}$ As pensões foram outorgadas pelo Congreso de la Nación Paraguaya pelas leis: $\mathrm{N}^{\circ} 671$ (1995); $\mathrm{N}^{\circ}$ 1756 (2001); N² 2491 (2004); N² 2653 (2005) e N³621 (2008).

${ }^{90}$ No original: El dúo Quintana-Escalante, en 1950, recogió fragmentos del compuesto en Puerto Guarani. Ya en Asunción, completaron sus estrofas. En 1957, en Buenos Aires, grabó la composición que, inmediatamente, se popularizó. Unos años después - según cuenta Martín Escalante-, un hombre humilde, que decía ser autor del compuesto, se presentó en su casa de San Vicente. Le pidió que compartiera con él la ganancia de un millón de guaraníes que la obra le había dado a él y a Carlos Quintana. "Había sido que un sobrino mío le dijo eso. Le mandé a Autores Paraguayos Asociados, APA. Y allí, para salir de su insistencia, le enviaron junto a Eladio Martínez, el recopilador de la obra. Éste, al que no le faltaba humor, al decirle que se había apoderado de su obra, le despachó con un "máva piko oñemomba'eséta te'onguére" (Quién querría adueñarse de un muerto) (ESCALANTE, 2017, online). Disponível em: https://www.facebook.com/asociacion.manduara/posts/mateo-gamarra-leyenda-orealidad-primera-partequien-m\%C3\%A1s-quien-menos-en-alg\%C3\%BAn-mom/10155390347096458/. Acesso em: 18 dez. 2018.
} 
o falecimento de Martín Escalante, se afirma que:

Durante sua carreira musical, Martín Escalante gravou cerca de 400 músicas, das quais 25 são da sua autoria, entre as quais se destacam 6 de enero, Che trigueñitami, Mateo Gamarra, Hoy desde lejos, 15 años poty, Morena'imi, e Ñembiso jovái. O artista conta com umas 30 músicas registradas em Autores Paraguayos Asociados (APA) (Última Hora, 2013, online - grifo nosso - tradução nossa ${ }^{91}$ ).

Essas duas reportagens questionam, portanto, a indicação de autoria por Estanislao Báez e Eladio Martinez. Outro aspecto que demonstra a fragilidade dos registros diz respeito à datação (Escalante afirma que compuseram e gravaram em 1957 e Báez registrou a música apenas em 1970). Cabe mencionar que tivemos acesso a vários discos de vinil originais do Duo Quintana Escalante e em nenhum deles encontramos referência ao ano de gravação do material, nem a autoria. A omissão de datas infelizmente é uma constante na maioria dos discos de música popular tradicional paraguaia. A falta de informações, somadas ao desinteresse e informalidade, gera uma lacuna no registro da história musical do país.

\section{III - Canção com detalhes de crônica policial}

Existem ainda outras questões não suficientemente aclaradas a respeito da história narrada no compuesto. Da própria letra buscamos depreender algumas informações. Logo nas duas primeiras estrofes se encontram referências de lugar, data, dia da semana e horário:

\footnotetext{
${ }^{91}$ No original: Durante su carrera musical, Martín Escalante grabó cerca de 400 temas, de los cuales 25 son de su autoría, entre los que se destacan 6 de enero, Che trigueñitami, Mateo Gamarra, Hoy desde lejos, 15 años poty, Morena'imi, y Ñembiso jovái. El artista cuenta con unos 30 temas registrados en Autores Paraguayos Asociados (APA) (Última Hora, 2013, online). Disponível em: https://www.ultimahora.com/fallece-el-cantante-y-compositor-del-mitico-duo-quintana-escalanten619478.html. Acesso em: $18 \mathrm{dez} .2018$.
} 


\author{
Mateo Gamarra (versão original) \\ I \\ Atención pido señores un momento pe hendumí \\ la desgracia ha sucedido en el Puerto Guaraní. \\ el 12 mes de octubre un baile ojeofrese \\ omanó Mateo Gamarra en manos de su mujer \\ II \\ O je'oi la farra hápe pe pyhareve asaje \\ rodando en este mundo para siempre en este día \\ el miércole desgraciado a las once del mediodía \\ en la casa de Miguel Medina la desgracia osucede.
}

\author{
Mateo Gamarra (tradução nossa) \\ I \\ Atenção peço senhores um momento pra ceis \\ ouvir \\ a desgraça que aconteceu em Puerto Guarani \\ no dia 12 de outubro um baile aconteceu \\ lá morreu Mateo Gamarra pelas mãos de sua \\ mulher \\ II \\ estavam indo pra farra que se ofereceu no meio \\ da manhã \\ rodando neste mundo para sempre nesse dia \\ a quarta-feira desgraçada às onze do meio-dia \\ na casa de Miguel Medina a desgraça aconteceu
}

Desse trecho podemos depreender a data do ocorrido, dia 12 de outubro. 0 dia da semana, quarta-feira. O horário, onze da manhã. O local, casa do Sr. Miguel Medina. A cidade, Puerto Guarani (situada no Chaco Paraguayo, no estado de Alto Paraná, Paraguay, na fronteira do Paraguay com o estado do Mato Grosso do Sul, Brasil).

Vale ressaltar que, no início da década de 1930, não eram todas as cidades que possuíam luz elétrica, ainda mais em cidades do interior. As festas aconteciam durante o dia por uma questão de falta de luz. Outro destaque vai para a data. Na maior parte da América Espanhola, na Espanha e nos Estados Unidos, dia 12 de outubro é El Día de la Raza. Esse dia é dedicado a relembrar a chegada de Cristóvão Colombo à América, ocorrida em 1492. No Brasil, dia 12 de outubro é feriado, dia de Nossa Senhora Aparecida, padroeira do Brasil, e dia das crianças. Obviamente, e não podemos deixar de registrar aqui, que as comemorações distintas aqui e lá, cujo objetivo político é reforçar as diferenças identitárias entre o Brasil e o restante da América Latina.

A comemoração ao dia da raça, quando se pensa na chegada dos espanhóis e depois dos portugueses, e todas as atrocidades que foram cometidas como violência aos povos que aqui viviam, pode ser lida como tentativa de valoração do feito espanhol, apaziguamento das violências cometidas entre as raças e/ou como pedido de desculpas. Cada país, ao nomear esse dia de sua própria maneira (na Espanha, é Día de la Fiesta Nacional ou Día de la Hispanidad; nos Estados Unidos, Columbus Day; no 
Chile e no Peru, Día del Encuentro de Dos Mundos; na Argentina, Día del Respeto a la Diversidad Cultural; no Paraguay, Día de la Raza) dá seu contorno específico a esse episódio. Os nomes formam e forjam as cicatrizes desse encontro.

Avançando na análise da letra do compuesto Mateo Gamarra, observamos que, curiosamente, apenas os homens são mencionados nas duas primeiras estrofes. Delfina Servín, esposa de Mateo, e Emilia Ortiz, mulher que Mateo paquera na festa, surgem apenas na terceira estrofe, e com prefixo "uma tal". O que não acontece com os homens Mateo Gamarra e Miguel Medina:

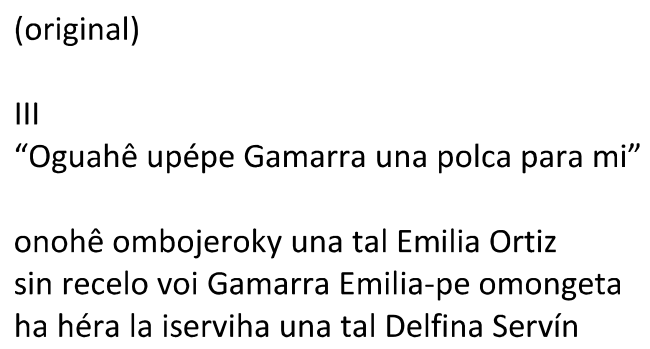

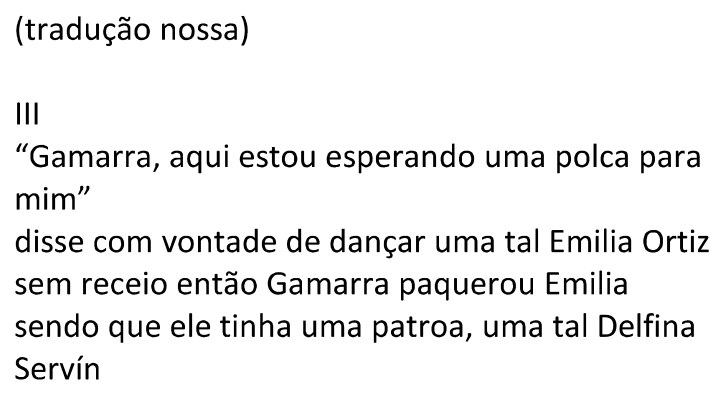
sem receio então Gamarra paquerou Emilia sendo que ele tinha uma patroa, uma tal Delfina Servín

O modo como são apresentadas as personagens femininas e a tensão entre o protagonismo de Mateo na narrativa e o protagonismo que Delfina assume nos eventos narrados nos leva ao seguinte ponto.

\section{IV - Machismos e feminismos impressos na letra - Reflexos da sociedade paraguaia}

Pensamos ser impossível explicar o sucesso desse compuesto no cancioneiro paraguaio sem ter em vista o papel da mulher na sociedade e na construção da identidade nacional paraguaia. Dentre outras coisas, foi por meio das mulheres que se deu a manutenção do idioma guarani como idioma oficial do território paraguaio. Segundo o pesquisador Oscar Creydt:

A causa fundamental pela qual o idioma da população oprimida se impôs como o principal idioma de toda a população da futura nação, deve ser buscada no papel predominante que as mulheres guaranis, como força de trabalho, desempenharam nas fazendas dos colonizadores.

Essas mulheres não estavam ali apenas para trabalhar, mas também para prover aos seus donos os numerosos filhos que trabalhariam nas fazendas no futuro. Entre a massa de mulheres escravizadas e 
dos conquistadores não existia uma relação de convivência entre iguais, mas uma relação de servidão pessoal. A maioria das servas mulheres residia nas fazendas, fora da cidade de Asunción. O senhor deixava a cargo das servas educar os filhos pequenos, dos quais se ocupava muito pouco. Com isso, os filhos mestiços aprenderam o idioma materno junto com o trabalho na fazenda. O guarani era o idioma da fazenda (CREYDT, 2010, p. 66 - tradução nossa ${ }^{92}$ ).

Outro aspecto a respeito do protagonismo das mulheres é sua importância na reconstrução do país depois da guerra travada entre o Paraguay e a Tríplice Aliança (composta pelo Brasil, Argentina e Uruguay) de 1864 a 1870. Segundo o censo realizado pelo governo provisório paraguaio entre 1870 e 1871, imediatamente depois da guerra, a população paraguaia estava reduzida a $116.351^{93}$ habitantes (MATOS, 2009, online). Sobre o perfil dessa população, se afirma que: “(...) aproximadamente 28 mil eram homens adultos. A relação de mulher por homem era, em geral, cerca de 4 para 1, mas haviam lugares onde chegava a 20 para 1 ou mais" (MATOS, 2009, online - tradução nossa $\left.{ }^{94}\right)$.

As mulheres eram, nesse momento, a imensa maioria das pessoas em idade e condições para trabalhar pela reconstrução do país, dizimada em mais da metade de sua população ${ }^{95}$. Não raro ouvimos referências ao matriarcado que fundamenta a identidade guarani.

\footnotetext{
${ }^{92}$ No original: La causa fundamental de que el idioma en la nacionalidad oprimida se impusiera como el principal idioma de todo el pueblo y de la futura nación, debe ser buscada en el papel predominante que las mujeres guaraníes, como fuerza de trabajo, desempeñaron en las chacras de los conquistadores.

Estas mujeres estaban allí no sólo para trabajarlas, sino también para proveer a sus dueños de numerosos hijos que las trabajaran en el futuro. Entre la masa de las mujeres esclavizadas y de los conquistadores no existía una relación de convivencia entre iguales sino una relación de servidumbre personal. La mayoría de las mujeres siervas residía en las chacras fuera del recinto de la "cuidad" de Asunción. El señor dejaba a cargo de sus siervas educar a los hijos pequeños, de los cuales se ocupaba muy poco. En consecuencia, los hijos mestizos aprendieron el idioma materno junto con el trabajo en la chacra. El guaraní era el idioma de la chacra (CREYDT, 2010, p. 66).

${ }^{93}$ Posteriormente, novas estimativas foram realizadas, já que na época era comum subestimar o número de crianças, e chegou-se a um número aproximado de 150 mil habitantes depois da guerra.

${ }^{94}$ No original: (...) solo aproximadamente 28.000 eran hombres adultos. La relación de mujeres por varón era en general de alrededor de 4 a 1, pero había sitios donde llegaba a 20 a 1 y más", dice el investigador (MATOS, 2009, online). Disponível em: https://reporterodelahistoria.blogspot.com/2009/09/holocausto-paraguayo-en-guerra-del-70.html. Acesso em: 18 dez. 2018.

${ }^{95}$ Para fins de comparação, e para precisar melhor quão sangrenta foi a guerra, temos dois dados conflitantes a respeito do número de habitantes do Paraguay antes da guerra. No livro do cronista belga Alfredo Marbais Du Graty "La Republique de Paraguay" (1865), o autor afirma que a população paraguaia era, em 1864, de cerca de 1 milhão de habitantes. Como Du Graty havia sido contratado pelo Marechal López para, por meio do livro, promover o país e seu regime, considera-se que esse número possa estar inflacionado. A outra referência populacional data do último censo antes da guerra, de 1846,
} 
Tendo essas premissas sócio históricas em vista, podemos nos dedicar às contradições presentes na tessitura da letra da canção. Nos chama a atenção a forma como foi construído o relato do assassinato de Mateo. Em primeiro lugar, o aspecto narrativo da canção dá a Mateo Gamarra o protagonismo da história. Já na primeira estrofe ele é apresentado: "lá morreu Mateo Gamarra pelas mãos de sua mulher".

$\mathrm{Na}$ terceira estrofe, encontramos novamente o caráter de protagonista creditado a Mateo. Emilia pede para dançar com ele, e ele logo se lança a paquerá-la, sendo que ele era casado, como ressalta a letra.

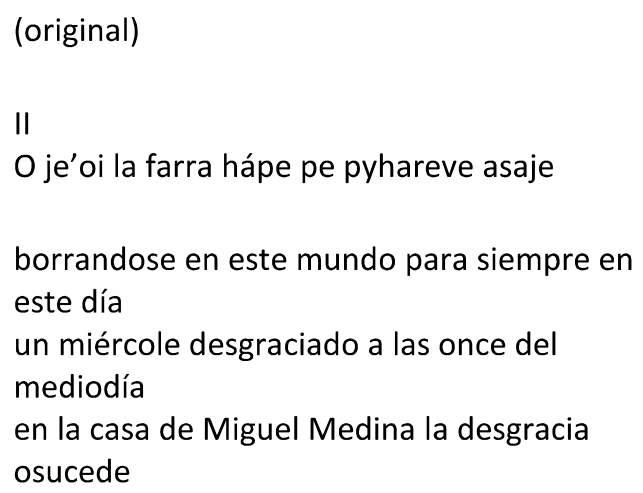

(tradução nossa)

II

estavam indo pra farra que se ofereceu no meio da manhã

apagando-se deste mundo para sempre nesse dia

uma quarta-feira desgraçada às onze do meiodia

na casa de Miguel Medina a desgraça aconteceu

III

"Gamarra, aqui estou esperando uma polca para mim"

disse com vontade de dançar uma tal Emilia Ortiz sem receio então Gamarra paquerou Emilia sendo que ele tinha uma patroa, uma tal Delfina Servín

IV

E desse jeito Gamarra continuou por toda a festa

Delfina cobrou dele "para com isso"

"não tem jeito", disse Gamarra e então continuou

"se te incomoda, eu posso te deixar e pronto"

para o qual a população era estimada em 238.862 habitantes (ainda considerando o mesmo problema do censo pós-guerra, a subestimação da população infantil). 
O diálogo que se trava entre o casal na estrofe 4 dá uma ideia da animosidade das palavras e ações de Mateo. A partir de então Delfina assume o foco da narrativa. Ela apresenta um discurso irônico e ameaçador na estrofe 5. Aqui, ela se recusa a ser "uma tal" e passa a se posicionar como a mulher. Se reconhece como mulher e precisamente desse lugar reclama respeito.

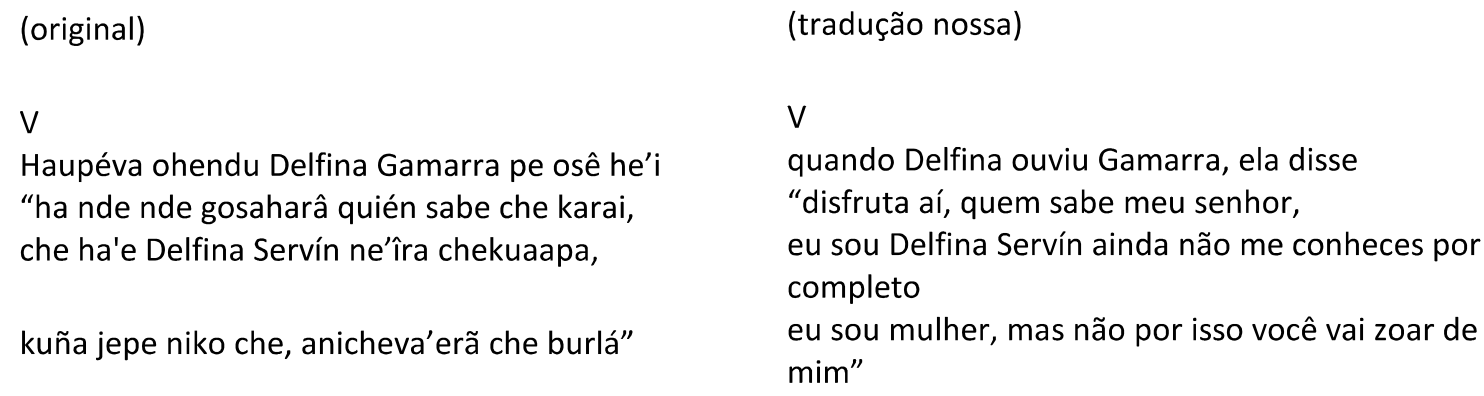

A estrofe 6 descreve a resposta de Delfina à situação colocada por Mateo. E, por fim, a reação de Mateo frente à ação executada por Delfina.

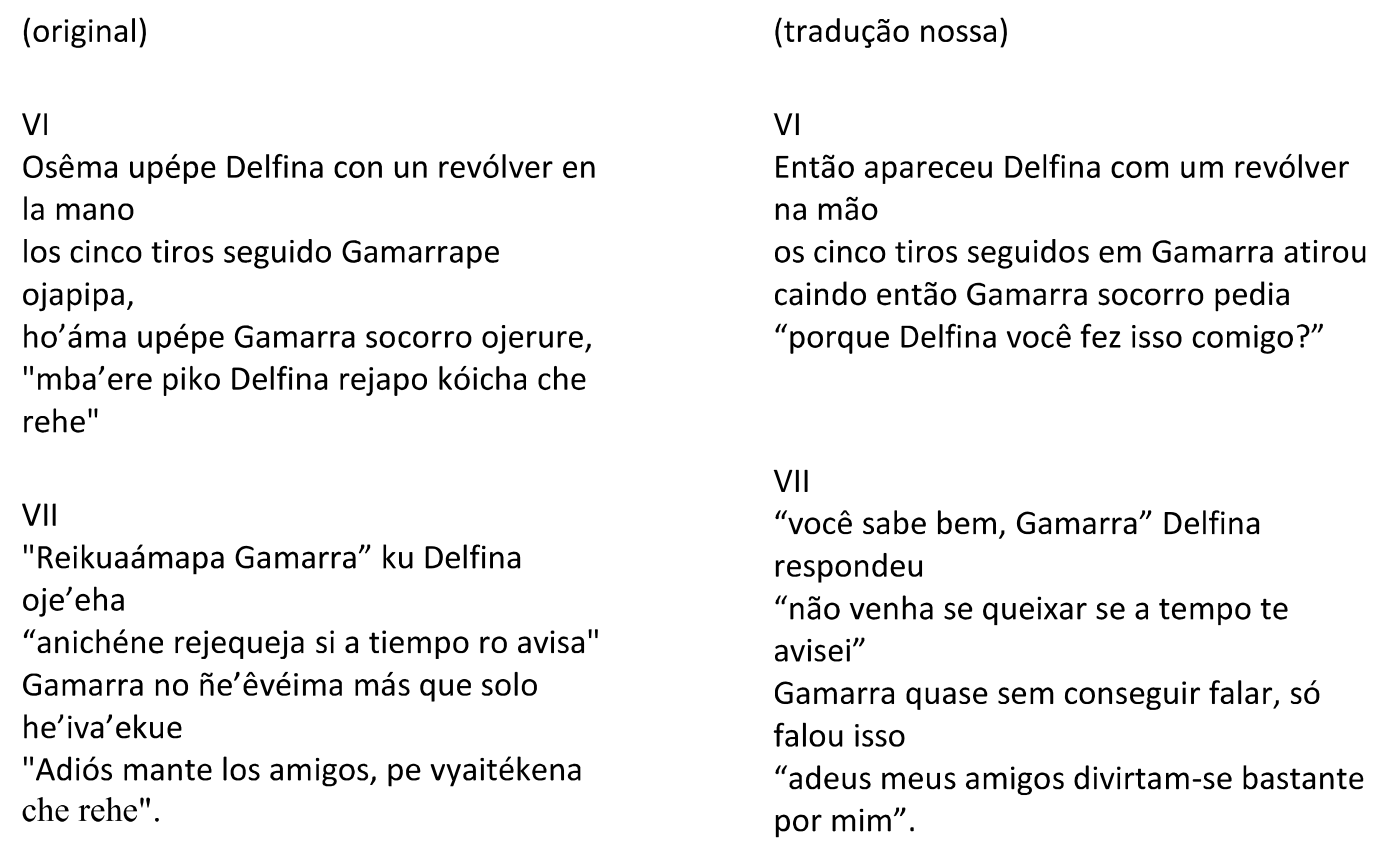

VI

Então apareceu Delfina com um revólver na mão

os cinco tiros seguidos em Gamarra atirou caindo então Gamarra socorro pedia "porque Delfina você fez isso comigo?"

VII

"você sabe bem, Gamarra" Delfina respondeu

"não venha se queixar se a tempo te avisei"

Gamarra quase sem conseguir falar, só falou isso

"adeus meus amigos divirtam-se bastante por mim". 
A resposta de Delfina, já na estrofe 7 , mostra uma mulher consciente de seus atos, no pleno de sua razão: “'você sabe bem, Gamarra' Delfina respondeu / 'não venha se queixar se a tempo te avisei' ${ }^{\prime \prime 96}$. Mas, como protagonista, a última palavra é de Mateo. Apesar de alvejado, ainda se dá a ele tempo de proferir o imperativo que encerra o compuesto. Esse pode ser lido como o momento mais falocêntrico da narrativa, em que o homem, mesmo ferido, demonstra que sua preocupação é manter a figura masculina no lugar de diversão e de prevalência sobre o feminino.

A título de ilustração, cabe mencionar uma das interpretações contemporâneas da música, apresentada em um programa de televisão ${ }^{97}$ sobre o episódio. A tensão no protagonismo das duas personagens (Mateo Gamarra e Delfina Servín) está presente na maneira brilhante como o músico Francisco Russo interpreta o compuesto. Por um lado, ele interpreta a fala proferida por Delfina como uma mulher cheia de si. Por outro, destaca o eu-lírico masculino do compuesto, aproxima a figura do narrador à do próprio Mateo, tirando o chapéu e despedindo-se do público como Mateo da vida.

\section{V - Tradição oral e memórias musicais compartilhadas}

As constantes transformações que experimentam as músicas de tradição oral transparecem nas diversas interpretações registradas. Existe um processo de apropriação e transformação por cada músico/musicista em sua interpretação de uma mesma obra. Procuramos observar algumas dessas particularidades a partir da transcrição de interpretações diferentes do compuesto Mateo Gamarra.

Embora o contorno melódico e o fraseado rítmico sejam parecidos nas versões, cada artista imprime sua particularidade no momento da execução. A partir de transcrições e análises de diversas interpretações do compuesto, ficam notórias as modificações de elementos. Transformações normais num repertório baseado na transmissão oral mestre/a-discípulo/a que se articula na esteira da narrativa pessoal,

\footnotetext{
${ }^{96}$ Em nossa pesquisa e processo de investigação sobre a música, chegamos a ponderar que, talvez, o elemento predominante para a ação que Delfina executa seja que a humilhação tenha ocorrido num espaço público. Ou seja, o que está em jogo nesse caso é sua honra. Talvez essa não tenha sido a primeira humilhação promovida por Mateo contra Delfina. Mas, certamente, foi a última.

${ }^{97}$ Programa televisivo "Música y Músicos del Paraguay", emissora Paraná HD, canal 33. Disponível em: <https://www.youtube.com/watch?time_continue=71\&v=bW5nvSrquol>. Acesso em: 15 dez. 2018.
} 
alimentada pelas inúmeras interpretações particulares que se conjugam na memória compartilhada por uma comunidade.

A primeira versão que vamos apresentar aqui é a do pesquisador Florentín Giménez (1997). O pesquisador, ao referir-se às transcrições realizadas, indica:

As transcrevi para que no futuro fiquem documentadas, cada uma na sua versão exata, e sobre cada uma delas, os intérpretes poderão colocar as repetições das letras até o fim de cada compuesto. Se incluem todos os textos dos compuestos na sua versão completa sem sofrer nenhum tipo de alteração, tal como foram recolhidos por Victor Barrios (GIMÉNEZ, 1997, p.263 - tradução nossa ${ }^{98}$ ).

Gimenez (1997) também indica que algumas das gravações que o pesquisador paraguaio Victor Barrios Rojas tem no seu acervo são bem antigas, inclusive algumas datam de 1910, sendo provável que a gravação de Mateo Gamarra que ele dispõe seja uma das primeiras. Porém Gimenez (1997) não faz indicação alguma sobre a origem da gravação que utilizou para realizar sua transcrição - não há referência nem à data de gravação, nem ao grupo que a executou. A seguir apresentamos a transcrição do pesquisador Florentín Gimenez, de 1997, para a primeira estrofe do compuesto. Vale observar que o pesquisador deixa registrado que se trata de um motivo popular, portanto, sem autoria definida.

\footnotetext{
${ }^{98}$ No original: Las transcribi para que en el futuro queden documentadas, cada una en su versión exacta, y sobre cada una de ellas, los intérpretes ya podrán ubicar las repeticiones de las letras hasta el final de cada compuesto. Se incluyen todos los textos de los compuestos en su versión completa sin sufrir ningún tipo de alteración, tal como fueron recogidos por Victor Barrios (GIMÉNEZ, 1997, p.263).
} 


\section{MATEO GAMARRA}

(Compuesto)
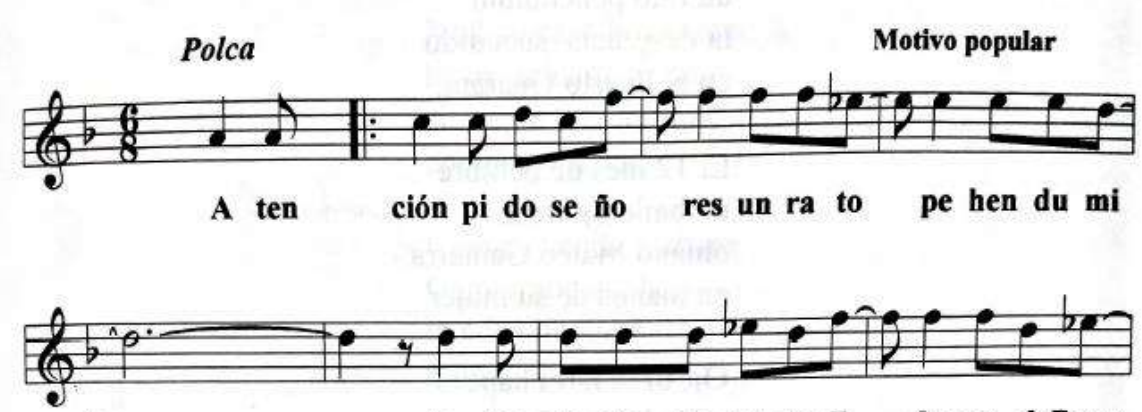

la des gra cia ha su ce di do en el Puer
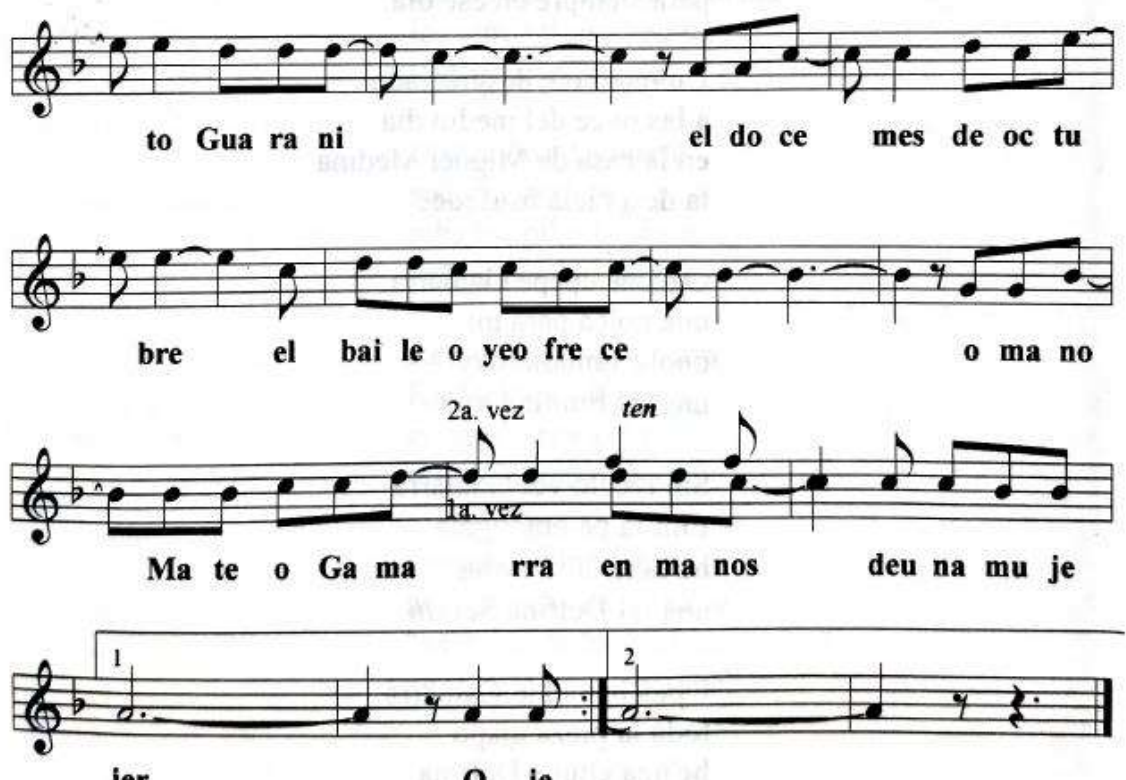

jer

o je

Para realizar nossa comparação e análise da transformação de elementos, realizamos a transcrição da melodia do compuesto, do mesmo trecho proposto por Gimenez, a primeira estrofe. Tomamos como referência para a transcrição a interpretação do Duo Quintana-Escalante no disco Duo Quintana Escalante y Su Conjunto Paraguayo CC 20038 APA-SADAIC (que não conta com indicação da data de gravação). 
Duo Quintana-Escalante y Su Conjunto Paraguayo CC. 20038 APA-SADAIC

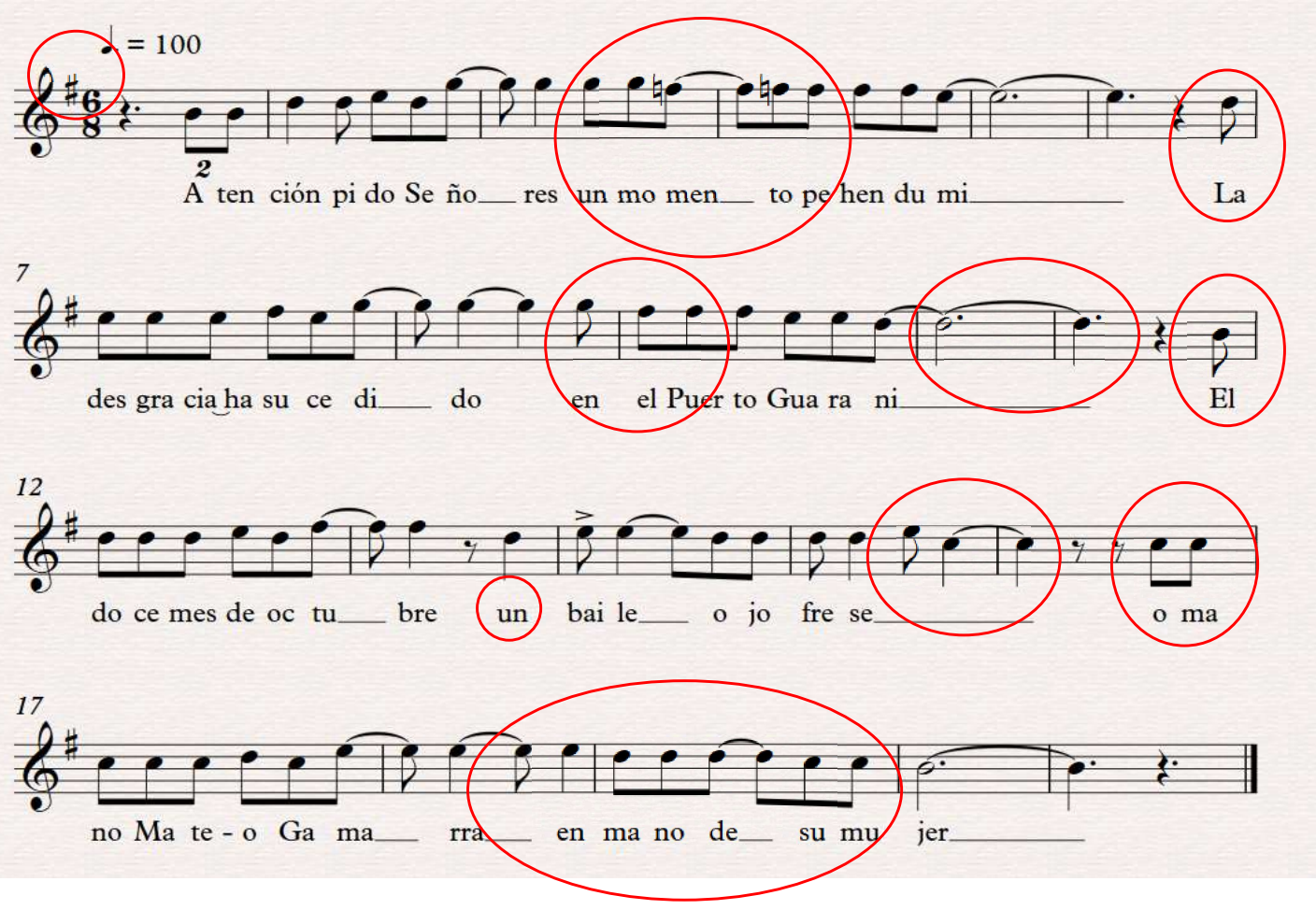

Comparando as duas versões constatamos que a transcrição de Gimenez (1997) não corresponde à gravação do Duo Quintana Escalante. Sinalizamos com círculos vermelhos os elementos diferentes encontrados nas duas transcrições.

A primeira diferença está na tonalidade da música. Gimenez (1997) fez a transcrição a partir de um registro na qual o grupo tocava em Fa maior. Por sua vez, o Duo Quintana Escalante gravou a música um tom acima, em Sol maior. As mudanças de tonalidade são um recurso comum no âmbito da canção, adequações necessárias para interpretar a melodia de acordo com o registro das vozes.

Outras diferenças mais significativas se dão na articulação rítmica das frases e no seu contorno melódico. Também observamos algumas trocas de palavras da letra. Na segunda metade do compasso 3, Gimenez escreve a palavra "rato" (tempo curto, poderia ser traduzido ao português como "um segundo") ao invés da palavra "momento", modificando a diç̧ão da frase seguinte, "pehendumi" (pra ceis ouvir). O início da frase que segue é interpretado de maneira diferente pelo Duo Quintana Escalante, colocando o início da palavra "desgracia" (desgraça) junto com o primeiro tempo do compasso 7. Esse deslocamento também ocorre no compasso 11, 
sincronizando a palavra "doce" (doze) com primeiro tempo do compasso 12 . Um deslocamento similar ocorre no compasso 16 com a palavra "omanó" (morreu), colocando a sílaba tônica da palavra no primeiro tempo do compasso 17.

Entre os compassos 8 e 9, na gravação do Duo Quintana Escalante, observamos diferenças de articulação rítmica e contorno melódico sobre a frase "en el Puerto". No compasso 13 ocorre uma pequena diferença na letra trocando-se o artigo definido "el" pelo artigo indefinido "un". Também observamos diferenças no final da frase no compasso 15, onde o duo acrescenta uma apogiatura. Finalizando, a última frase é interpretada pelo duo com a letra "en mano de su mujer" (pelas mãos de sua mulher), com a palavra "mano" iniciando no primeiro tempo do compasso 19, enquanto Gimenez (1997) transcreve a frase com a letra "en manos de una mujer" (pelas mãos de uma mulher) esticando a última sílaba, que não é tônica, da palavra "manos" até o primeiro tempo do compasso 19. Aqui, destacamos ainda, a diferença simbólica que existe entre as frases: (i) "pelas mãos de sua mulher", ou seja, foi assassinado por sua companheira, alguém que lhe era familiar e, (ii) "pelas mãos de uma mulher", que destaca o gênero da executante do crime, informação mais relevante do que a familiaridade das mãos que cometem a ação.

As transcrições comparadas se dedicaram apenas ao primeiro verso do compuesto, mas já aí nesse curto trecho indicam diferenças perceptíveis na apropriação e interpretação da canção, característica intrínseca ao repertório de música popular tradicional.

\section{Considerações finais}

Como discutimos ao longo deste artigo, apesar de existirem muitos indícios que reforçam o caráter de veracidade do acontecimento, vale dizer que o destino das principais personagens é incerto. Sobre Emilia Ortiz e Miguel Medina, não temos quaisquer notícias. Sobre Delfina Servín, as notícias não passam de lendas: "Segundo o boca-a-boca, Delfina Servín cumpriu sua pena na prisão e passou seus últimos anos como vendedora de flores em frente ao Cemitério La Recoleta. Apesar disso, na prisão 
feminina não existem registros sobre ela" (VERGARA apud DIAZ, 2012, online ${ }^{99}$ ). Cabe ressaltar que a prisão feminina em Asunción está situada ao lado do cemitério La Recoleta.

A imprecisão das pesquisas sobre o acontecimento, sobre a autoria da obra e, enfim, sobre o destino dessas pessoas - bem como a insistência de artistas ao longo desses, pelo menos 80 anos, em contar e recriar esse episódio dão testemunho de sua força. E as lacunas, mais do que revelar problemas e impossibilidades, elas mesmas nos apontam, como procuramos demonstrar, para as especificidades da história paraguaia em seus aspectos sócio históricos. Como afirma a pesquisadora Ecléa Bosi (2013) sobre a relevância da narrativa oral, elemento fundamental desse compuesto e substrato da presente pesquisa: "Esquecimentos, omissões, os trechos desfiados de narrativa são exemplos significativos de como se deu a incidência do fato histórico no cotidiano das pessoas. Dos traços que deixou na sensibilidade popular daquela época" (Bosi, 2013, p.18).

Os compuestos ocupam precisamente a função de fazer de uma história uma narrativa de amplo conhecimento. Sua potência como memória está nas (re)interpretações que inspira. Nós mesmos, os autores desse artigo, nos debruçamos sobre essa obra para produzir um trabalho performativo indisciplinar, que denominamos Delfina, realizado pelo grupo Kairospania Cia Cênico Sonora ${ }^{100}$, cuja estreia aconteceu em 13 de setembro de 2018, em Buenos Aires, Argentina. A performance Delfina também contou com apresentações em São Paulo, uma delas no dia de aniversário do fatídico episódio, 12 de outubro de 2018, integrando o festival Satyrianas.

As obras criadas, bem como as lendas e histórias que se somam à história original, mostram a força dessa narrativa que segue viva, questionando, provocando, alimentando mitos e impressionando artistas, ouvintes e espectadores.

\footnotetext{
99 No original: "Según el "boca a boca", Delfina Servín cumplió una condena en prisión y pasó sus últimos años como florista frente al Cementerio de la Recoleta. Sin embargo, en el penal de mujeres no existen registros sobre ella" (VERGARA apud DIAZ, 2012, online). Link para o site: http://www.abc.com.py/especiales/fin-de-semana/historia-de-un-crimen-que-se-hizo-leyenda462673.html. Acesso em: 20 dez. 2018.

${ }^{100}$ Na performance Delfina, Kairospania Cia Cênico Sonora é formada por: Carmen Estevez, Nahnati Francischini, Samya Enes, Yonara Dantas, André Teles, Fábio Manzione e Migue Antar.
} 
Anexo

Mateo Gamarra (versão original)

I

Atención pido señores un momento pe hendumí

la desgracia ha sucedido en el Puerto

Guarani

el 12 mes de octubre un baile ojeofrese omanó Mateo Gamarra en manos de su mujer

II

O je'oi la farra hápe pe pyhareve asaje rodando en este mundo para siempre en este día

el miércole desgraciado a las once del mediodía

en la casa de Miguel Medina la desgracia osucede

III

"Oguahê upépe Gamarra una polca para mi"

onohê ombojeroky una tal Emilia Ortiz

sin recelo voi Gamarra Emilia-pe omongeta ha héra la iserviha una tal Delfina Servín

IV

Upéicha ndaje Gamarra toda la pieza ojapo he'íma chupe Delfina "anivéna péicha reiko"

"no hay caso", he'i Gamarra ha upéichante oseguí

"si es que ojedigustárõ che apoíntene ichugui".

$\mathrm{V}$

Haupéva ohendu Delfina Gamarra pe osê he'i

"ha nde nde gosaharâ quién sabe che karai, che ha'e Delfina Servín ne'îra chekuaapa, kuña jepe niko che, anicheva'erã che burlá"

VI

Osêma upépe Delfina con un revólver en la mano

los cinco tiros seguido Gamarrape ojapipa, ho'áma upépe Gamarra socorro ojerure, "mba'ere piko Delfina rejapo kóicha che rehe"

VII

"Reikuaámapa Gamarra" ku Delfina oje'eha "anichéne rejequeja si a tiempo ro avisa" Gamarra no ñe'êvéima más que solo he'iva'ekue

"Adiós mante los amigos, pe vyaitékena che rehe".

Mateo Gamarra (tradução nossa)

I

Atenção peço senhores um momento pra ceis ouvir

a desgraça que aconteceu no Puerto

Guarani

no dia 12 de outubro um baile aconteceu lá morreu Mateo Gamarra pelas mãos de sua mulher

II

estavam indo pra farra que se ofereceu no meio da manhã

rodando neste mundo para sempre nesse dia

a quarta-feira desgraçada às onze do meiodia

na casa de Miguel Medina a desgraça aconteceu

III

"Gamarra, aqui estou esperando uma polca para mim"

disse com vontade de dançar uma tal Emilia Ortiz

sem receio então Gamarra paquerou Emilia sendo que ele tinha uma patroa, uma tal Delfina Servín

IV

E desse jeito Gamarra continuou por toda a festa

Delfina cobrou dele "para com isso"

"não tem jeito", disse Gamarra e então continuou 
"se te incomoda, eu posso te deixar e pronto"

V

quando Delfina ouviu Gamarra, ela disse "disfruta aí, quem sabe meu senhor, eu sou Delfina Servín ainda não me conheces por completo eu sou mulher, mas não por isso você vai zoar de mim"

VI

Então apareceu Delfina com um revólver na mão

os cinco tiros seguidos em Gamarra atirou caindo então Gamarra socorro pedia "porque Delfina você fez isso comigo?"

VII

"você sabe bem, Gamarra" Delfina respondeu

"não venha se queixar se a tempo te avisei"

Gamarra quase sem conseguir falar, só falou isso

"adeus meus amigos divirtam-se bastante por mim". 


\section{REFERÊNCIAS}

BOETTNER, Juan Max. Música y Músicos del Paraguay. Asunción: Edición de autores paraguayos asociados, 2011.

BOSI, Ecléa. O tempo vivo da memória: ensaios em psicologia social. São Paulo: Ateliê Editorial, 2003.

COBUSSEN, Marcel. The Field of Musical Improvisation. Leiden: Leiden University Press, 2017.

CREYDT, Oscar. Formación Histórica de la Nación Paraguaya: pensamiento y vida del autor. Asunción: Servilibro, 2010.

GIMENEZ, Florentín. La música paraguaya. Editorial El Lector. Asunción Paraguay 1997.

GRATY, Alfredo Marbais du. La République du Paraguay. Bruxelles: C. Muquardt, 1865.

HIGA, Evandro Rodrigues. Polca paraguaia, Guarânia e Chamamé: Estudos sobre três gêneros musicais em Campo Grande - MS. Campo Grande: UFMS, 2010.

PENNER, Hedy; ACOSTA, Soledad; SEGOVIA, Malvina. El descubrimiento del Castellano paraguayo a través del Guaraní: Una historia de los enfoques lingüísticos. Asunción: Ceaduc, Centro de Estudios Antropológicos Universidad Católica Nuestra Señora de la Asunción, 2012.

SZARAN, Luis. Diccionario de la música en el Paraguay. Asunción: Société Générale de Surveillance, 1999.

\section{Referências online:}

MATOS, Jorge Moreno. Holocausto paraguayo en Guerra del '70. In: El Reportero de la Historia. 27 set. 2009. Disponível em: $<$ https://reporterodelahistoria.blogspot.com/2009/09/holocausto-paraguayo-en-guerra-del70.html>. Acesso em: 18 dez. 2018.

Riveros, Justiniano. La polca "Mateo Gamarra", una historia verídica que cumplió 86 años. In: Última hora. 13 de out. 2017. Disponível em: <https://www.ultimahora.com/la-polca-mateogamarra-una-historia-veridica-que-cumplio-86-anos-n1112958.html>. Acesso em: $18 \mathrm{dez}$. 2018.

VALINOTTI, Elvio Díaz. La segunda muerte de "Mateo Gamarra". In: ABC Color. 19 out. 2012. Disponível em: <http://www.abc.com.py/especiales/fin-de-semana/mateo-gamarra-elhombre-que-murio-dos-veces-466373.html>. Acesso em: 18 dez. 2018.

. Historia de un crimen que se hizo leyenda. In: ABC Color. 12 out. 2012. Disponível em: <http://www.abc.com.py/especiales/fin-de-semana/historia-de-un-crimen-que-se-hizoleyenda-462673.html>. Acesso em: 18 dez. 2018.

Recopilación de motivos populares del Paraguay. In: ABC Color. 16 mar 2010. Disponível em: $<$ http://www.abc.com.py/edicion-impresa/artes-espectaculos/recopilacion-de-motivospopulares-del-paraguay-79509.html>. Acesso em: 18 dez. 2018.

Emblemática figura de nuestra musica: Martín Escalante, el músico humilde, incansable, cordial. In: Musica Paraguaya. Disponível em: <http://www.musicaparaguaya.org.py/escalante.html>. Acesso em 18 dez. 2018.

Mateo Gamarra: ¿Leyenda o realidad?. In: Asociación Cultural Mandu'ara. Disponível em: $<$ https://www.facebook.com/asociacion.manduara/posts/mateo-gamarra-leyenda-o-realidad- 
primera-partequien-m\%C3\%A1s-quien-menos-en-alg\%C3\%BAn-mom/10155390347096458/>. Acesso em: 18 dez. 2018.

\section{Vídeo:}

Programa televisivo "Música y Músicos del Paraguay", da emissora Paraná HD, canal 33. Disponivel em: <https://www.youtube.com/watch?time_continue=71\&v=bW5nvSrquol>. Acesso em: 15 dez. 2018. 
ANEXO B. ARTIGO: DESINTEGRAÇÃO DE VOZES, REINTEGRAÇÃO DE POSSES: APONTAMENTOS SOBRE A POLCA PURAHEI JAHE'O COMO NARRATIVA DE ASPECTOS SÓCIO-HISTÓRICOS DA CULTURA PARAGUAIA 


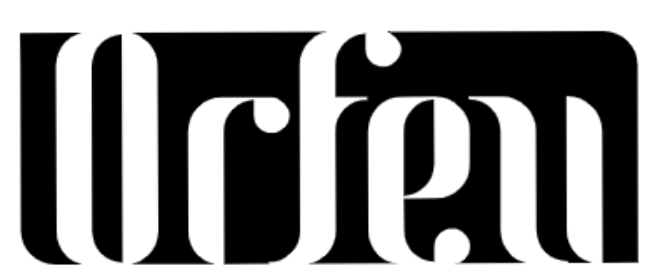

RevistadoPrograma dePós-Graduaçãoem MÚSICA I CEART |UDESC

\section{V. is Publicação ก. i. Contínua}




\section{Sumário}

\section{Expediente}

\section{Seção artigos demanda contínua}

Onze prelúdios para piano solo de Edmundo Villani-Côrtes: uma análise para a compreensão do potencial didático da obra para o desenvolvimento de habilidades técnico-interpretativas Luciana Hamond

A didática na literatura de técnicas estendidas de produção de som para violino Lourenço De Nardin Budó

Play along ou play alone?: um estudo sobre presença e interatividade na livre improvisação musical

Fabio Manzione Ribeiro

Pernambuco "feminina", Mulher fêmea sim!: a mulher na mazurca do Alto do Moura: culturas, vivências e músicas

Marília Paula dos Santos

Três gravações de campo na cidade do Rio de Janeiro

Alexandre Sperandéo Fenerich

DIÁLOGOS DESCLASSIFICADOS Música e corpo-arquivo na construção de um saber inacabado, primeiros passos

Erickinson Bezerra de Lima e Klênio Barros

Propuestas pedagógicas y estéticas de El Sistema: Un estudio de caso del SOJ

Viviana Carolina Jaramillo Alemán

O ensino das artes na educação básica frente aos ordenamentos vigentes

Sonia Regina Albano de Lima

Timelines na Coisa no 5 de Moacir Santos

Fabio Marinho

Equivalência de itens, semântica e operacional da "Escala de Musicabilidade: Formas de Atividade, Estágios e Qualidades de Engajamento"

Aline Moreira Brandão André, Cristiano Mauro Assis Gomes e Cybelle Maria Veiga Loureiro 
JPMB: Qualificação da performance no contexto da educação musical comunitária em cidades interioranas de Alagoas

Marcos Santos Moreira

Desintegração de vozes, reintegração de posses: apontamentos sobre a polca purahei jahe'o como narrativa de aspectos sócio-históricos da cultura paraguaia Miguel Díaz Antar e Yonara Dantas de Oliveira

ADAPTAÇÃO E VALIDAÇÃO SEMÂNTICA DO THINKING STYLES INVENTORY - REVISED II (TSI-R2) PARA AS LICENCIATURAS EM MÚSICA NO BRASIL

Sérgio Inácio Torres, Graziela Bortz e Katya Luciane de Oliveira

A música sacra no reinado de Leopoldo I (1658-1705)

Caio Amadatsu Griman e Dorotéa Machado Kerr

\section{Seção Estréias}

Das mortes nas estações?

Dierson Torres e Marília Santos 


\title{
Desintegração de vozes, reintegração de posses: apontamentos sobre a polca purahei jahe'o como narrativa de aspectos sócio-históricos da cultura paraguaia
}

\author{
Miguel Díaz Antar ${ }^{1}$ \\ Universidade de São Paulo (USP) \\ miguedz5@gmail.com \\ Yonara Dantas de Oliveira ${ }^{2}$ \\ Universidade de São Paulo (USP) \\ yoyodantas@gmail.com
}




\section{Resumo}

No presente artigo discutimos como a música popular paraguaia, em especial as do tipo polca purahei jahe'o, pode ser acionada como material fundamental para uma pesquisa sócio-histórica a respeito da cultura paraguaia. No presente estudo selecionamos a polca Propiedad Privada como material de análise e dela depreendemos dois aspectos: (i) a situação da mulher na cultura paraguaia e (ii) a questão fundiária. Ambos aspectos se apresentam na letra da música a partir de uma certa ambiguidade de sentido. Não se pode afirmar, com certeza, se a letra se refere a um ou outro tema. $A$ potência da canção, sob nossa perspectiva, reside justamente nessa capilaridade que permite tratar de ambos assuntos. E desses dois aspectos, que parecem díspares, vamos descortinando parte importante da história paraguaia e elementos característicos de sua cultura. Infelizmente, vemos desvelada também a reiteração de uma violência social que mantém os/as oprimidos/as em condição de subserviência e pobreza.

Palavras-chave: Purahei jahe'o, música paraguaia, matriarcado, nacionalismo, música e sociedade.

\section{Abstract}

In this article we discuss how Paraguayan popular music, especially those of the purahei jahe'o polka type, can be used as fundamental material. We selected the song Propiedad Privada as material for analysis and we deduced two aspects from it: (i) the situation of women in Paraguayan culture and (ii) land dispute. Both aspects appear in the lyrics of the song from a certain ambiguity of meaning. It cannot be said with certainty whether the lyrics refer to one or the other subject. The power of the song, from our perspective, lies precisely in that capillarity that allows the two themes to be connected. And from these two aspects that seem disparate, we are discovering an important part of Paraguayan history and the characteristic elements of its culture. Unfortunately, we also see the reiteration of social violence that keeps the oppressed in a condition of servility and poverty.

Keywords: Purahei jahe'o, Paraguayan music, matriarchy, nationalism, music and society.

\section{Resumen}

En este artículo discutimos cómo la música popular paraguaya, especialmente las del tipo polca purahei jahe'o, puede ser accionada como material fundamental para una investigación socio histórica sobre la cultura paraguaya. Para el presente estudio seleccionamos la canción Propiedad Privada como material para análisis y dedujimos dos aspectos de ella: (i) la situación de la mujer en la cultura paraguaya y (ii) disputa 
de la tierra. Ambos aspectos aparecen en la letra de la canción a partir de una cierta ambigüedad de significado. No se puede decir con certeza si la letra se refiere a uno u otro tema. La potencia de la canción, desde nuestra perspectiva, radica precisamente en esa capilaridad que permite conectar ambos temas. Y a partir de estos dos aspectos que parecen dispares, observamos una parte importante de la historia paraguaya y los elementos característicos de su cultura. Desafortunadamente, también vemos la reiteración de la violencia social que mantiene a los/as oprimidos/as en una condición de servilismo y pobreza.

Palabras clave: Purahei jahe'o, música paraguaya, matriarcado, nacionalismo, música y sociedad.

1 Doutorando do Departamento de Música da Escola de Comunicações e Artes. Participa do Núcleo de Pesquisas em Sonologia - NuSom USP. Agência de fomento: FAPESP (processo n²017/09285-9). Formou-se em música no Ateneo Paraguayo. Integra os grupos Ôctôctô, Joaju, DuoCoz, Camerata Profana, Filarmônica de Pasárgada e KairosPania Cia. Cênico Sonora. Membro da Orquestra Errante, coletivo experimental que se dedica à prática da improvisação contemporânea e faz parte do projeto NuSom - Núcleo de Pesquisa em Sonologia, da ECA-USP. Desenvolve pesquisas artísticas na relação entre composição e improvisação musical contemporâneas. Como instrumentista tem participado de diversos festivais em países como Alemanha, Argentina, Bolívia, Brasil, Estados Unidos, Inglaterra, Luxemburgo, Paraguay, Portugal e Uruguay.

2 Pesquisadora com formação interdisciplinar, está atualmente desenvolvendo o pós-doutorado na ECA/USP. Graduada, mestre e doutora em Psicologia. Atriz formada pelo Teatro Escola Célia Helena. Dentre seus trabalhos artísticos, destacam-se a direção de performances na Kairospania Cia Cênico-Sonora (Transposições, 2016; Suíte [en]quadrada, 2017; Des a a vel, 2017; A Síria não é aqui, 2017 e Delfina, 2018), atuação na peça "O Dragão Dourado" e atuação e direção da peça "Barbazul", ambas da Trupe à Grega (antes denominado Coletivo Quartocê). Atua, dirige e produz espetáculos de teatro e de música na cidade de São Paulo. É professora na Escola Superior de Artes Célia Helena, onde também já atuou como coordenadora de cursos de pós-graduação em artes. Participa dos Laboratório de Livre Improvisação Orquestra Errante e do Núcleo de Pesquisas em Sonologia da USP - NuSom. 


\section{Introdução}

A música popular latino-americana é um vetor de afetos. Ela concentra e traduz experiências políticas, econômicas e sociais que marcam profundamente a vida de populações das mais diversas classes sociais. Ela, por sua própria natureza calcada na palavra, dialoga com uma tradição de cultura popular ancorada na transmissão oral - as letras das canções são meios narrativos para contação de histórias, experiências e sentimentos. E, ainda precisamente por sua oralidade, exige uma análise musical que vá mais além do material composicional, e considere o seu contexto sócio-histórico. Ter em vista essas especificidades, na opinião do pesquisador Evandro Higa (2013), minimiza "o risco inevitável de cair nas armadilhas do anacronismo de uma musicologia já superada" e que, sob esse prisma, pode acabar por reforçar "repertórios e ambientes musicais dominados por concepções elitistas e preconceituosas" (HIGA, 2013, p.12).

O presente estudo toma como referência essa perspectiva para pensar a música popular paraguaia, entendendo-a como parte fundamental do amplo panorama da música popular latino-americana. Escolhemos uma polca popular paraguaia como material de análise e procuramos ressaltar tanto os elementos musicais inerentes à obra em questão como as possíveis interferências culturais que podem ser depreendidas do próprio material. A partir da análise de elementos sociais e culturais ali impressos, observamos valores sócio-históricos impregnados nesse repertório e que, por vezes, passam desapercebidos na cultura paraguaia, ofuscados pela repetição e naturalização dos discursos. E elevamos a música popular a material privilegiado de pesquisa, contrapondo-nos, portanto, a visões elitistas sobre tal repertório - que tende a menosprezá-lo. Como Higa (2013) afirma, a música popular se encontra "em um contexto de lutas simbólicas complexas, não há como abrir os ouvidos para essa música e fechar os olhos para as redes de significação que a configuram" (HIGA, 2013, p.16). É dessa forma que observamos elementos tais como nacionalismo, heroísmo, elogios à mulher, romanticismo, machismo, misoginia, xenofobia, violência social etc. se misturam no caldeirão de polcas e guarânias que formam a música tradicional popular do Paraguai.

A música que selecionamos como material de análise é a polca Propiedad Privada, do músico paraguaio Cecilio Mareco Pereira (1943 - ), uma composição amplamente difundida e gravada no Paraguai. Como já citado, a partir dessa música depreendemos reflexões sobre aspectos sócio-históricos presentes na cultura paraguaia. Especificamente dois aspectos que atravessam a cultura paraguaia: (i) a questão de gênero e (ii) a questão fundiária. Ambos se encontram impressos como faces complementares de uma ambiguidade impressa na letra da canção e oferecem um bom pano de fundo para pensarmos a cultura e a sociedade paraguaias - tanto naquilo que a une à experiência latino-americana, como naquilo que a torna singular. 


\title{
1 - Sobre a polca Propiedad Privada: entre a posse de terras e a ob- jetificação de mulheres
}

A canção, letra e música, Propiedad Privada pertence ao conjunto de composições da música folclórica tradicional e popular do Paraguai. Seu autor - Cecilio Mareco Pereira - é um músico paraguaio nascido na Cidade de Ybycui em 1943. Desde criança, Cecilio teve contato com o ambiente musical graças a seu pai e seus tios, que eram músicos. Ainda adolescente, por volta de 1955, Cecilio mudou-se para cidade fronteiriça de Posadas, na Argentina. O novo endereço ficava na mesma rua que o prédio da emissora "LT4 Rádio Missiones", destacada na época por abrigar conjuntos musicais folclóricos nacionais e internacionais para apresentações ao vivo na rádio. Em pouco tempo, Cecilio passou a frequentar as apresentações in loco, e logo a integrar grupos de música tradicional paraguaia, destacando-se como letrista de novas composições.

\begin{abstract}
Na década de 1970, integrou o conjunto "A lo Valleté", que gravou dois LPs no selo Cerro Corá e outro no selo Vapor Cué. Com este conjunto teve bons momentos pois tiveram várias atuações por todo o território paraguaio e outros países, entre os quais parte da república da Argentina, Brasil e Bolívia, lugares onde "A lo Vallete" fez grande sucesso com o estilo de música que interpretavam. Depois disso outro grupo foi criado e desta vez com o nome "Grupo Electrónico 93" e tiveram 14 dos temas de maior sucesso gravados. E assim foi triunfando com seus diferentes temas que foram, são e seguem sendo gravadas até hoje em dia (PORTAL GUARANI, online, s/d - tradução nossa ${ }^{3}$ ).
\end{abstract}

Depois de morar muitos anos no exterior, Cecilio voltou para o Paraguai e se aposentou 4 . Para o presente trabalho procuramos contato com ele, o que não foi viabilizado por motivos de saúde.

Apesar da importância do trabalho de compositores de música popular tradicional, como Cecilio Mareco Pereira, tendo em vista que reinterpretações e regravações de músicas tradicionais populares são bastantes comuns nos grupos paraguaios, a questão de registro e nomeação da autoria das músicas ainda é bastante falha. Nem sempre estão inseridas nas capas dos discos informações importantes como a origem das músicas gravadas, os locais e datas do processo de gravação - isso se observa tanto nos antigos discos de vinil como nos mais recentes CDs. É o que se observa com a polca Propiedad Privada. Atualmente é possível encontrar muitas gravações da polca, mas poucas fazem referência ao seu autor, Cecilio Mareco Pereira. Assim, com o objetivo de confirmar a autoria da polca Propiedad Privada entramos em contato com a instituição paraguaia

No original: "En la década del 70 formó el conjunto 'A lo Valleté' con el que grabó dos LP en el sello Cerro Corá y otro en el sello Vapor Cué. Con este conjunto pasó buenos momentos ya que tenían varias actuaciones por todo el territorio paraguayo y otros países, entre ellos parte de la república de Argentina, Brasil y Bolivia en donde 'A lo Vallete' tuvo gran éxito con el estilo de música que interpretaban. Ya después otro grupo fue creado y esta vez con el nombre de 'Grupo Electrónico 93' en donde 14 de los temas de mayor éxito fueron grabados. Y así fue triunfando con sus diferentes temas que fueron, son y siguen siendo grabados hasta hoy en día" (PORTAL GUARANI, online, s/d).

4 Cecilio Mareco Pereira passou a receber pensión graciable do governo paraguaio, através da Ley №2820, de 3 de novembro de 2005. Disponivel em: https://www.bacn.gov.py/leyes-paraguayas/1908/ley-n-2820-concede-pension-graciable-al-senor-cecilio-marecos-pereira-gran-exponente-del-folklore-nacional (acesso em outubro 2020). 
APA - Autores Paraguayos Asociados - que confirmou Cecilio como autor da polca e acrescentou que a música foi registrada na instituição no dia 4 de novembro de 2011.

Aqui se reforça um ponto importante a respeito da música paraguaia: existe pouca preocupação com uma documentação sistemática das obras musicais - tanto por parte dos/as artistas como por parte da própria instituição responsável pela documentação. Além da já citada despreocupação de artistas em nomear compositores das canções gravadas, bem como das datas e locais de gravação de seus álbuns, mesmo na instituição responsável pela documentação - a APA - não há registro, por exemplo, da data de composição da obra. Assim, a data de registro (realizada por vezes muitos anos depois que a música foi composta) se torna a única referência temporal da música e pode se confundir com a data de composição - o que dificulta o trabalho de potenciais pesquisadores e pode levar a confusões no registro da história da música popular paraguaia. Mais do que apontar para uma má-fé dos/as artistas que gravaram as músicas e da instituição responsável por essa documentação, tal falha nos parece que revela uma certa displicência a respeito da necessidade de documentação dos processos criativos em música. Revela, ainda, a necessidade de fortalecimento desse tipo de produção acadêmica.

A pesquisa sobre música do Paraguai tem se intensificado nos últimos anos, sendo o trabalho do Prof. Dr. Evando Higa (pesquisador brasileiro que publicou um dos primeiros trabalhos acadêmicos sobre música paraguaia) um dos marcos fundamentais de referência. Ele abre caminho e se soma a outros marcos importantes, como a criação, em meados de 2010, do curso público de Graduação em Música em Asunción, Paraguay ${ }^{5}$ - o que faz com que seja necessário um maior rigor no processo de documentação com vistas a viabilizar o trabalho de pesquisadores em música e, como consequência, uma maior capacidade dos artistas paraguaios de nomear e de ter acesso à sua própria história.

Como já mencionamos, a polca Propiedad Privada conta com muitas gravações. Uma das versões mais emblemáticas e que obteve bastante sucesso de público foi registrada no segundo disco do grupo "Odilio Román y Los Románticos Vol.2", lançado no início da década de $2000^{6}$. Ou seja, mais de dez anos antes do registro de autoria da música por Cecilio na APA. No disco a que tivemos acesso - fazendo coro à lacuna de documentação citada - não se indicam informações a respeito da autoria ou da data de gravação.

Odilio Román (1969-2019) - foi um representante do gênero polca paraguaia sendo autor de várias músicas de sucesso no passado recente, além de intérprete de músicas consagradas. Nasceu em setembro de 1969 na cidade de San Pedro del Paraná a 80 km de Encarnación - cidade fronteiriça do Paraguai com a Argentina - e a 306 km da capital Asunción. Com o grupo "Odilio Román y Los Románticos" obteve grande destaque no cenário musical do Paraguai, participando em diversos festivais folclóricos e fiestas patronales, muito comuns no interior do país. O grupo gravou 29 álbuns e realizou algumas turnês internacionais pela Europa.

\footnotetext{
5 A data precisa de início do curso de graduação em música é incerta. No site da Facultad de Arquitectura, Diseño y Arte da Universidad Nacional de Asunción não é possível encontrar tal informação. Considera-se 2010 como parâmetro a partir da conversa com pesquisadores e professores vinculados a essa instituição.

6 Tomamos o cuidado de sempre, tanto quanto possível, destacar informações sobre data e autoria das obras citadas. Esse tema da falta de referências está presente também em outro artigo que produzimos, qual seja, "Apontamentos sobre narrativa oral, identidade, machismos e feminismos no compuesto Mateo Gamarra" (ANTAR; OLIVEIRA, 2019), listado nas referências ao final desse artigo.
} 
O falecimento de Odilio em agosto de 2019, em consequência de uma doença hepática, foi muito sentido no país e obteve ampla cobertura dos meios de comunicação ${ }^{7}$. Coincidentemente no dia de seu falecimento, domingo 4 de agosto de 2019, estávamos retornando de Asunción para São Paulo em uma viagem de carro. Durante todo o caminho em território paraguaio ouvimos nas distintas rádios locais homenagens e dedicatórias ao artista acabara de partir. Também foram tocadas reiteradas vezes as músicas gravadas por Odilio e Los Románticos, entre elas, Propiedad Privada.

O repertório do grupo Odilio Román y Los Románticos se caracterizava pelo forte uso do idioma guarani, predominante no interior do país (em contraposição à capital, Asunción, onde se utiliza mais comumente o espanhol e o jopará, mistura entre espanhol e guarani). A estética do grupo pode ser considerada uma versão contemporânea do purahei jahe'o (canto lamentoso, canto choroso), gênero da polca paraguaia que ganha destaque no país a partir da década de 1970 e que se caracteriza pelo vínculo das letras com a vida rural. Pesquisadores como Szarán (1999) e Pereira (2011) apontam que o termo jahe'o (lamentoso, choroso) surgiu com uma conotação pejorativa, remetendo ao modo pelo qual músicos/musicistas urbanos criticavam as canções do interior do país, cuja temática geralmente gira em torno das histórias do campo, luta social e desenganos amorosos. Cabe destacar que o gênero purahei jahe'o surge nas últimas décadas da ditadura militar no Paraguai (1954-1989), momento em que despontam com maior organização as lutas pelos direitos humanos e pela reforma agrária nos movimentos camponeses.

No contexto de polcas purahei jahe'o ganha destaque a sonoridade proposta pelo grupo liderado por Odilio, que lança mão de guitarra elétrica, teclado, baixo elétrico e bateria eletrônica em substituição da instrumentação tradicional dos primeiros grupos do gênero que utilizavam violão, harpa paraguaia, acordeón e contrabaixo. A relação entre música e tecnologia, os diversos grupos e as diversas estéticas sonoras de música paraguaia a partir de instrumentos elétricos, as instrumentações híbridas (instrumentos acústicos + instrumentos elétricos), a influência de estéticas importadas, são alguns dos pontos que ainda precisam ser estudados no que se refere a instrumentação na música tradicional popular do Paraguai nas últimas décadas do século XX. Neste trabalho nos dedicamos apenas a proposta do grupo de Odilio que explora, a partir da sonoridade com instrumentos elétricos, um repertório característico do purahei jahe'o. $\mathrm{O}$ amplo alcance de público diz respeito a simpatia estética e a reverberação do conteúdo das letras.

A gravação da polca Propiedad Privada por Odilio y Los Románticos no início dos anos 2000 é sem dúvida uma das principais referências da música e retoma reinvindicações que ecoam na música popular paraguaia há muito tempo. As narrativas associadas ao contexto rural, com sua sonoridade típica de instrumentos acústicos (violão e harpa paraguaia), são revisitadas com a roupagem da instrumentação elétrica e amplamente difundidas no interior do Paraguai. O problema da distribuição de terra no Paraguai e a situação da mulher no contexto de países latino-americanos e no Paraguai especificamente, são dois grandes problemas sociais e ecoam em diversas músicas tradicionais e populares do Paraguai, desde as primeiras décadas do século XX, como Chokokue 
Purahei (1938) e Ha mboriahu (1943), como veremos adiante. Essas questões também podem ser refletidas a partir da letra da polca Propiedad Privada.

Na letra da polca Propiedad Privada, observa-se um caráter duplo, uma engenhosa ambiguidade entre disputa de terra e mulher como objeto de posse. Sugere-se a audição ${ }^{8}$ e a leitura da letra sob uma perspectiva e, na sequência, sob a outra. Observe:

\begin{tabular}{|c|c|}
\hline Versão original & Português (tradução nossa) \\
\hline Verso 1 & Verso 1 \\
\hline Propiedad Privada ningo & Propriedade Privada era \\
\hline $\begin{array}{l}\text { Aikuaámiýre che mba'e } \\
\text { roguáicha amokunu'u }\end{array}$ & $\begin{array}{l}\text { E sem saber, como se fosse minha } \\
\text { eu a mimava }\end{array}$ \\
\hline Chupépe ahaihúva & E por amá-la tanto \\
\hline amojerovia iporãve háicha & a tratava com carinho (como a mais linda) \\
\hline $\begin{array}{l}\text { Mamoiko imo'ata } \\
\text { ijaratee oguerekoha }\end{array}$ & $\begin{array}{l}\text { Sem imaginar sequer } \\
\text { que tinha dono }\end{array}$ \\
\hline Coro & $\underline{\text { Refrão }}$ \\
\hline Mba'éiko ajapóta & O que farei? \\
\hline Mamóiko aháta & Onde irei? \\
\hline Che yvoty ahaihúva & Para que a flor que amo \\
\hline Oúmi hagua & volte a mim \\
\hline Koka'aruetévo & E quando cai a tarde \\
\hline aha'aroitéva & em vão espero \\
\hline aikuaa porãva & pois sei muito bem \\
\hline mba'e ajeno ha & que de outro ela é \\
\hline Verso 2 & Verso 2 \\
\hline Ko'anga aikuaáma mba'epa & Agora sei muito bem quanto \\
\hline ovale Propiedad Privada & vale uma Propriedade Privada \\
\hline Aimo'avyetére pe ahaihuetéva & quando eu menos esperava \\
\hline Che año apyta aieplaquea & $\begin{array}{l}\text { ful abandonado } \\
\text { Fiquei só queixando-me }\end{array}$ \\
\hline kutyre'y míchã & como órfão \\
\hline Mba'érepa péicha & Por que isso aconteceu comigo? \\
\hline ahendavy'ai añekonsola & estou triste e sem consolo \\
\hline Coro & Refrão \\
\hline Verso 3 & Verso 3 \\
\hline Agüi añeha'a tama'e & De agora em diante terei \\
\hline porãpe che raperáre & muita atenção em meu caminho \\
\hline anive haguáma Propiedad & para que nunca mais volte \\
\hline Privada peajoikéve & a entrar em Propriedade Privada \\
\hline Porque ambyasy añarrepenti & Porque estou muito triste e \\
\hline che rembiapo kuére & arrependido de minhas ações \\
\hline Na cheko'aveima já & Pois já não tenho \\
\hline aperdetéva ahaihúva che & perdi aquela que amo \\
\hline Coro & Refrão \\
\hline
\end{tabular}


À primeira vista, a letra parece referir-se a uma mulher. No entanto, ela cabe perfeitamente para pensar a posse de terras. Ao se manter ambígua, mantem-se também, em certo sentido, irônica. A potência da canção é justamente essa capilaridade que permite conectar ambos assuntos. Seria essa ambiguidade precisamente uma crítica social disfarçada de música de amor? Sob a leitura de uma música de amor, trata de uma relação amorosa calcada na ideia de posse, com a mulher representada como objeto. Se como canção amorosa, a polca Propiedad Privada se destaca pela objetificação da mulher, como canção que trata da terra, pode ser vista como registro das precárias condições agrárias do país. Adiante trataremos dessas duas possíveis chaves de leitura que a letra da canção suscita.

\title{
2 - A força da música folclórica e popular no Paraguai
}

Os dois gêneros de música paraguaia mais famosos são a polca paraguaia e a guarânia. Ambos compartilham da polirritmia que caracteriza a música paraguaia. Esta acontece na sobreposição da melodia em compasso binário com uma seção rítmica em compasso ternário. Embora a pulsação sempre tenha como referência a semínima pontuada (que em 6/8 corresponde a dois pulsos por compasso), a execução de três semínimas no baixo amalgama uma sonoridade que intercala dois pulsos contra três e três pulsos contra dois, numa "alternância diacrônica de ritmos binários e ternários" (HIGA, 2010, p.163). A partir desses encontros emerge outra característica importante que é designada pelo pesquisador Max Boettner como o "sincopado paraguaio".

\begin{abstract}
Boettner (...) se refere ao sincopado paraguayo existente na melodia quando esta se adianta ou atrasa sobre o ritmo do acompanhamento e afirma que nunca se tem a sensação de sincopas propriamente ditas, mas sim a 'sensação de uma despreocupación languida, de una dejadez encantadora'" (HIGA, 2010, p.163 grifo no original).
\end{abstract}

Além do sincopado paraguaio característico de ritmos ternários e binários, na música tradicional popular do Paraguai ficam evidentes outros dois elementos: o idioma guarani e o sistema tonal. Para o pesquisador Gonzalo Ortiz (2018), entre 1811 (ano da independência) e 1972 (ano da primeira composição pós-tonal Dos piezas para piano9 ${ }^{\text {, }}$ de Luis Szarán), a música no Paraguai foi eminentemente folclórica ${ }^{10}$. Nessa perspectiva

\footnotetext{
9 "O ano de 1972 marca o início da música contemporânea para piano no Paraguai com as Dos Piezas para piano de Luis Szarán, Adagio e Allegro. 0 Adagio combina a sonoridade de acordes atonais com efeitos como notas presas, é uma peça que exige muita concentração do intérprete no ataque e na pedalização para garantir a duração das notas e acordes longos. 0 Allegro é uma peça de carácter humorístico onde a ideia de surpresa resulta dos acordes abruptamente interrompidos e respostas musicais inesperadas" (ORTIZ, 2018, p.62 - grifo no original).

10 De modo geral, as manifestações da cultura popular que caracterizam a identidade social de um povo são nomeadas como folclore. A palavra foi amplamente adotada a partir da proposta do pesquisador Willian John Thoms, em 1846, para referir-se aos conhecimentos e saberes do povo. Para o pesquisador Alberto Ikeda (2013), o termo folclore sofre um desgaste semântico por conta de estudos que descontextualizavam particularidades culturais das suas funções e sentidos profundos na sociedade onde se preservam, provocando visões distorcidas e preconceituosas que operam apenas com interesses estéticos ou de entretenimento. "Tais enfoques provocaram nas pessoas visão negativa a respeito desses fatos, como se fossem expressões curiosas, rústicas, anedóticas, exóticas diante da vida moderna, vinculados aos ignorantes e à pobreza" (IKEDA, 2013, p.186).
} 
musical, os vários períodos de semi-isolamento ${ }^{11}$ (geográfico, político e idiomático) vivenciados pelo país favoreceram a consolidação de particularidades sonoras e a quase nula interferência de referências externas. Assim, durante muito tempo, a música popular paraguaia, urbana e rural, foi a própria música folclórica do país.

Sobre o idioma utilizado nas letras das músicas, destaca-se que a grande maioria das polcas e guarânias foram compostas no idioma guarani ou em jopará. Vale ressaltar que o jopará é muito utilizado na comunicação no dia a dia, no cotidiano das pessoas. E por meio das letras se constitui e se consolida muito do imaginário acerca da cultura paraguaia, profundamente fundado na transmissão oral. É nesse sentido que pesquisadores como Evandro Higa (2010) e Eduardo Chamorro (2013) apontam para a importância das narrativas presentes e transmitidas nessas músicas. Nelas, se destaca a construção do imaginário coletivo com base no heroísmo do seu povo nas grandes guerras, a exaltação da figura da mulher, o amor e a entrega pela pátria - motivos frequentes nas letras.

Sobre essa perspectiva musical, o pesquisador Gonzalo Ortiz (2018) faz o seguinte resumo:

Desde 1811, momento em que o Paraguai deixa de ser colônia espanhola e vira país soberano, até 1972, ano da primeira peça pós-tonal para piano, a música no país foi eminentemente folclórica. A música era para festas, destinada à dança, servia para incentivar o patriotismo (principalmente nas duas grandes guerras [internacionais] que enfrentou o país) e para render homenagem a pessoas proeminentes. A totalidade da música no Paraguai foi, por muito tempo, o seu folclore. Aí se reconhecem dois ritmos principais: a polca e a guarânia; a instrumentação desses ritmos era violão e harpa paraguaia. A canção se desenvolveu junto com essas duas bases, rítmica e instrumental, sendo a língua guarani um forte diferencial (ORTIZ, 2018, p.15).

Embora tenham sido inauguradas algumas instituições de ensino musical ${ }^{12}$ nas primeiras décadas após a Guerra da Tríplice Aliança ${ }^{13}$ (1864 - 1870), durante quase todo o

110 Paraguai passou por períodos de maior e menor grau de isolamento. Sua condição de país mediterrâneo somada a algumas políticas de estado, promoveram uma falsa visão de isolamento total por parte dos críticos, em especial durante o período de governo do Dr. Francia entre 1814 e 1840. 0 pesquisador Creydt (2010) denuncia esta falsa perspectiva assinalando políticas de comercio da época com países como Inglaterra, Brasil, Argentina e Uruguai. As cláusulas e condições exigidas pelo Paraguai, que não agradaram a elite de comerciantes, foram os principais motivos das interpretações distorcidas, pois essas clăusulas apontavam "acabar com a situação de dependência, herdada da colônia, desenvolvendo as forças produtivas sobre uma base independente" (CREYDT, 2010, p.90 - tradução nossa). 0 pesquisador Richard White (1989) acrescenta que o Dr. Francia se opunha ao intercambio comerciar exterior como uma atividade exclusiva dos proprietários dos meios de produção e comercio, pois, "já não conduzido por e para a oligarquia - era regulamentado pelo estado para beneficiar a nação inteira, ou seja, ao povo paraguaio (WHITE, 1989, p.180 - tradução nossa).

Após o período de governo do Dr. Francia ocorre outro momento de semi-isolamento do país imerso na pior de suas guerras, a da Tríplice Aliança (1864-1870) e o período posterior de reconstrução. Todavia, conflitos internos (20 golpes de estado, 1 assassinato presidencial, 2 triunviratos, 1 nova guerra internacional e 1 guerra civil) levaram o Paraguai a ter entre 1870 e 1954, cinquenta e dois presidentes. 0 ditador Alfredo Stroessner assume em 1954 através de mais um golpe militar e fica no poder até 1989. Durante seus 35 anos de terror o país sofre o enclausuramento cultural imposto e controlado pelo regime.

120 Ateneo Paraguayo foi fundado em 1883. O Instituto Paraguayo foi fundado em 1895. Em 1913 de inaugura o Gimnasio Paraguayo. A partir de 1933 as duas últimas se juntam ao Ateneo Paraguayo e formam uma só instituição de ensino, em funcionamento até hoje. Ainda cabe destacar a criação da Escuela de los Aprendices Músicos Militares, fundada por volta de 1820, nos primeiros anos de governo do Dr. Francia, e que promoveu “o florescimento das Bandas de músicos e da música nos tempos dos López (PEREIRA, 2011, p.47 - tradução nossa).

13 A Guerra da Tríplice Aliança (1864-1870) também é nomeada por diversas/os pesquisadoras/es como Guerra Grande, Guerra del 70;, Guerra Guazú e/ou Guerra do Paraguai. 
século XX a música folclórica e música popular se confundiram numa mesma prática. Nesse sentido, a constante presença desse repertório na cultura não compactua com a ideia de um folclore petrificado, como afirmam alguns estudos. A transmissão de experiências fortemente calcada na oralidade faz com que, a cada nova interpretação de uma mesma música, constantes transformações sejam incorporadas ao material a partir das experiências e experimentações de cada artista. É o que indica o pesquisador Juan Orrego Salas:

(...) sempre existirá um índice de diferenciação proveniente da pessoa e da sua forma individual de assimilar o aporte ambiental. Nesse sentido, cada artista é então fonte geradora da sua própria tradição. A tradição é continuidade e é mudança. Envolve um ato de adesão ao passado e, simultaneamente, um outro de reinterpretação e adaptação às pulsações transformadoras da vida (SALAS apud TORRES, 1988 , p.60 - tradução nossa $\left.{ }^{14}\right)$.

É dessa forma que a música folclórica do Paraguai se mantém viva e potente. Novas composições são incorporadas ao repertório, mas sobretudo, não raro (re)interpreta-se o remanescente de canções épicas que contam as glórias das batalhas e exaltam seus heróis e heroínas - que formam uma parte muito importante desse repertório que continua sendo fortemente cultivado até hoje no país.

Essas características marcantes da cultura paraguaia não podem ser desvinculadas da história do país e seus vizinhos, de maneira que muitas das manifestações culturais são resultado dessas, por vezes conflituosas, relações. A pesquisadora Gaya Makaran aponta que "o nacionalismo paraguaio, criador de mitos nacionais que sobrevivem até nossos dias, aparece pela primeira vez durante a Guerra da Tríplice Aliança (1864-1870), um acontecimento traumático e crucial para a sociedade paraguaia" (MAKARAN, 2013, p.44 - tradução nossa ${ }^{15}$ ). Essa guerra é tida como um dos momentos mais críticos da história do Paraguai que na ocasião perdeu entre $70 \%$ e $90 \%$ da sua população masculina. Como indica a pesquisadora, o discurso nacionalista ganha suma importância a partir desse momento, e precisamente surge aí a elevação da figura feminina como heroína nacional:

(...) transformando-o num novo começo mítico da nação, sacrificada e purificada pelo fogo do combate e ressuscitada das cinzas por suas mulheres. É lá onde se enraízam as principais figuras simbólicas da mulher paraguaia (...) (MAKARAN, 2013, p.53 - tradução nossa ${ }^{16}$ ).

\footnotetext{
14 No original: (...) siempre existirá un índice de diferenciación proveniente de la persona y de la forma individual de asimilar el aporte ambiental. En ese sentido, cada artista es entonces fuente generadora de su propia tradición. La tradición es continuidad y es cambio. Envuelve un acto de adhesión al pasado y, simultáneamente, uno de reinterpretación y adaptación a las pulsaciones cambiantes de la vida (SALAS apud TORRES, 1988, p.60).

15 No original: El nacionalismo paraguayo, creador de los mitos nacionales que han sobrevivido hasta nuestros días, aparece por primera vez durante la Guerra de la Triple Alianza, un acontecimiento traumático y crucial para la sociedad paraguaya (MAKARAN, 2013, p.44).

16 No original: (...) convirtiéndolo en un nuevo inicio mítico de la nación, sacrificada y purificada por el fuego del combate y resucitada de las cenizas por sus mujeres. Es allá donde se enraizan las principales figuras simbólicas de la mujer paraguaya (...) (MAKARAN, 2013, p.53).
} 
Os relatos sobre os horrores da guerra e as narrativas sobre a sua superação consolidam a imagem da mulher paraguaia como reconstrutora e defensora do país e a partir dessa imagem se alimenta o mito sobre o sistema matriarcal no Paraguai. A importância da figura feminina como base da cultura paraguaia é uma das faces da música Propiedad Privada e sobre esse aspecto trataremos a seguir.

\title{
3 - A mulher reconstrutora do país? Música e discursos sobrepon- do-se às ações
}

\author{
Propriedade Privada era \\ a quem eu amava \\ E sem saber, como se fosse minha \\ eu a mimava \\ E por amá-la tanto \\ a tratava com carinho (como a mais linda) \\ sem imaginar sequer \\ que tinha dono
}

Não dá para negar que a Guerra da Tríplice Aliança foi uma catástrofe para o Paraguai e impôs para a mulher a condição de restauradora da pátria. $\mathrm{O}$ âmbito musical reitera essa posição da mulher, sendo muito elogiada e exaltada como a guardiã da cultura, do idioma e da nação, em inúmeras polcas e guarânias que relatam o heroísmo e entrega das mulheres.

Nesse contexto, se destaca a posição da mulher/mãe como cabeça da casa e como a heroína que levanta a família e o país em contraste com a ausência, voluntária ou não, do homem. É o que diz, por exemplo, a música Mujer Paraguaya ${ }^{17}$ de Manuel Frutos Pane (1906-1990): "quando seu marido vai para a guerra, ela é a alma que resguarda bem a sua casa, ela é a alma da sua terra, ela é a alma luminosa da sua raça". Também são representativas as músicas Residenta altiva, de Rafael Paeta (1946- 1997) com o grupo Los Indianos; A la residenta, de Juan Manuel Marcos (1950 - ) e Carlos Noguera (1950 - ), e muitas outras.

Contudo, ao indagarmos com mais cuidado sobre os valores impressos nos discursos naturalizados pelo repertório tradicional popular do país, procuramos observar o que se esconde por trás desse discurso oficial: a mulher paraguaia encontra mesmo o respeito e reconhecimento que merece? Será a cultura paraguaia um oásis em meio ao patriarcado predominante nos demais países latino-americanos? A pesquisadora Makaran (2013) aponta a respeito:

As referências ao Paraguai como um "país de mulheres" se referem mais à quantidade delas do que a sua posição social, e menos ainda a um domínio político feminino. Do mesmo modo, a palavra "matriarcado" não corresponde ao verdadeiro significado do termo: poder, governo das mulheres, mas se refere a uma vantagem demográfica e como consequência à onipresença feminina. Ao evo- 
car o mito do matriarcado, o discurso nacionalista encobre o triste fato de que as mulheres foram reconstrutoras sem poder, monopolizado pelos homens (...) O único papel que tinha reservado para elas o país de pós-guerra, ou ironia profundamente patriarcal, era serem cidadãs de segunda [categoria] sem direitos políticos, servas da pátria e da família que com sacrifício e abnegação levantam o país dirigido por homens (MAKARAN, 2013, p.59 - tradução nossa ${ }^{18}$ ).

Apesar de atualmente observarmos a ocupação de mulheres ${ }^{19}$ em cargos públicos e movimentos femininos empenhados em tentar reverter essa situação, a participação das mulheres em cargos decisórios continua enfrentando obstáculos. Segundo a pesquisadora Mary Monte de López (2020), "a luta por expor agressões, desigualdades e estereótipos se intensificou nos últimos anos, no entanto, este trabalho de conscientização não parece suficiente para que as injustiças percam força" (LÓPEZ apud CUEVAS, 2020, online - tradução nossa ${ }^{20}$ ). E, assim, infelizmente, a referência a mulher como objeto de posse na canção Propiedad Privada não é tão despropositada - a mulher como objeto, não como sujeito: "Mamoikoimo'ata / ijaratee oguerekoha" (sem imaginar sequer / que tinha dono).

Também é digno de nota que as mulheres do Paraguai tenham sido as últimas do continente a conquistar o direito a voto ${ }^{21}$, somente em 1961, em plena ditadura militar. Exatamente durante o longo e cruel governo do ditador Alfredo Stroessner (1912-2006), que governou durante 35 anos, entre 1954 e 1989, se desenvolveu a fase militar mais violenta, repressiva e autoritária do nacionalismo paraguaio. Nesse cenário, o direito a voto feminino foi uma conquista importante na luta de resistência ao regime. No entanto, tratou-se de uma conquista simbólica, sem efeito real. Tanto o voto masculino como o feminino só se tornaram efetivos após a abertura democrática, em 1989, depois de 35 anos de ditadura militar e a triste consolidação da corrupção estrutural do governo e a naturalização de discursos opressores na cultura popular.

Dentre as figuras femininas de destaque na história e cultura paraguaias é impossível não se lembrar de Elisa Lynch (1833-1886). Ela concentra em sua trajetória muito das contradições observadas no que se refere ao tratamento dado à mulher.

\footnotetext{
18 No original: Las referencias a Paraguay como "un país de mujeres" aluden más bien a la cantidad de éstas y no a su posición social, ni mucho menos a un dominio político femenino. De igual manera, la palabra "matriarcado" no corresponde al verdadero significado del término: poder, gobierno de las mujeres, sino que se refiere más bien a una ventaja demográfica y como consecuencia a la omnipresencia femenina. Al evocar el mito del matriarcado, el discurso nacionalista encubre el triste hecho de que las mujeres fueron reconstructoras sin poder, monopolizado éste por los hombres (...) El único papel que tenía reservado para ellas el país de posguerra, o ironía profundamente patriarcal, era el de las ciudadanas de segunda sin derechos políticos, de sirvientas de la patria y familia que con su sacrificio y abnegación levantan el país dirigido por hombres (MAKARAN, 2013, p.59).
}

19 Como exemplos de mulheres em cargos do governo paraguaio temos Soledad Núnez, Ministra da Secretaria Nacional de la Vivienda, e Magali Cáceres, Ministra de la Juventud - ambas no Governo de Horácio Cartes (2013-2018).

20 No original: "La lucha por exponer agresiones, desigualdades y estereotipos se intensificó en los últimos años; sin embargo, esta labor de concientización no parece suficiente para que las injusticias pierdan fuerza" (LÓPEZ apud CUEVAS, 2020, online).

21 Promulgada pela lei $\mathrm{N}^{\circ} 704$ em julho de 1961. Pode ser acessada no site da Biblioteca y Archivo Central del Congreso de la Nación no link: http://www.bacn.gov.py/leyes-paraguayas/252/ley-n-704-derechos-politicos-de-la-mujer (acesso abril 2020). 


\section{1 - Elisa Lynch - a figura feminina em meio a guerra}

A consolidação do regime militar no Paraguai se apoiou no nacionalismo Lopizta, por meio do resgate da figura do marechal Francisco Solano López (1827 - 1870) como símbolo máximo da entrega e patriotismo. Apesar de parecer uma estratégia original do regime militar para consolidar politicamente seu poderio, o resgate da figura de López no imaginário paraguaio é anterior. A partir das primeiras décadas do século XX se iniciou um movimento de revisão -histórica pelo grupo de intelectuais conhecido como "Generación del 900" - que dentre outras coisas, foram os responsáveis pela revisão histórica de López e da Guerra da Tríplice Aliança. O ditador Stroessner se aproveitou desse movimento para encobrir seu regime sob a cortina da "boa ditadura" e do "patriotismo heroico" e, com isso, consolidar seu poder (LAMBERT, 2013). Além da figura do marechal, o regime também apostou na reabilitação da figura de sua companheira Elisa Alicia Lynch.

Elisa Alisa Lynch nasceu em 3 de junho de 1835 na ilha de Cork, Irlanda. Os jovens Francisco e Elisa se conheceram em Paris nos primeiros anos da década de 1850 durante uma viagem diplomática à Europa do então filho do presidente do Paraguai. Apesar de sua condição de mulher divorciada, algo raro à época, López decide trazê-la ao Paraguai para que seja sua companheira. A união do casal sempre esteve em evidência, sendo alvo de críticas e maledicências. Apesar disso, tiveram sete filhos e se mantiveram lado a lado durante a guerra. E se tornaram personagens bastante atacadas no período que se seguiu.

Segundo a pesquisadora Natalia Neres da Silva (2015), tanto Lopez quanto Lynch foram duramente atacados com o final da guerra. No entanto, tendo sobrevivido, ela teve que lidar com as consequências: "além de ser expulsa do país, ela também teve a grande maioria dos seus bens confiscada, se tornou protagonista de biografias maledicentes e foi mencionada de forma pejorativa em relatos de oficiais militares, além de ter sido alvo de charges e publicações em diversos jornais" (DA SILVA, 2015, p.1-2).

Obviamente, o Brasil, país vencedor, não perdeu a oportunidade de ridicularizar seus opositores. E ambos foram alvo da imprensa. O pesquisador Mauro César Silveira afirma que nos jornais de aqui: "enquanto Solano López era mais alvejado no seu controvertido caráter, a deformação da imagem da irlandesa Elisa Alicia Lynch atingia sobretudo sua fisionomia, profundamente alterada nas caricaturas publicadas na imprensa da Corte. Nos desenhos, a companheira do Mariscal aparecia com traços físicos defeituosos e um proeminente nariz (...)" (SILVEIRA, 2015. p.128). As deformações, no entanto, não se concentravam apenas nas caricaturas. "Nas legendas - e nos textos maiores, como os editoriais -, era descrita como a 'perdição' de López, que mandava dentro e fora de casa, e a responsável pela "megalomania" do chefe de governo do Paraguai. O coronel Centurión refere, sem muita convicção, a capacidade persuasiva de Madame Lynch, como era mais conhecida (...)" (SILVEIRA, 2015. p.128). Lynch também foi acusada de cometer atos perversos, ter se apropriado de joias de outras mulheres, enviando-as para o exterior ou enterrando-as na selva. 
Embora a relação entre Francisco e Elisa tenha sido alvo de controvérsias, muitas delas infundadas e arbitrárias, é certo que eles estiveram juntos até o trágico final do marechal em 1 de março de 1870, quando ele foi assassinado em Cerro Corá.

E, como dito anteriormente, a história de ambos foi apropriada e utilizada como argumento de reiteração dos propósitos ditatoriais de Stroessner.

Stroessner se apoiou enormemente na recuperação da personagem, e se apresentou como herdeiro político de López, o grande símbolo do nacionalismo sob o qual o regime se assentou (...). Esse nacionalismo lopizta se impôs com farto apoio de instituições estatais, através da perseguição do pensamento crítico nas universidades, pela censura à imprensa e por meio de grande propaganda ideológica (...). Em relação especificamente à Elisa Lynch, um dos passos mais interessantes do ditador foi o translado dos seus restos mortais, que até então se encontravam na França, para o cemitério "La Recoleta" de Assunção, em 1961. $\mathrm{Na}$ sepultura onde os restos mortais de Elisa foram depositados, foi construída uma grande estátua, na qual a personagem é representada de forma altiva, frente aos túmulos de Solano López e Panchito, seu filho primogênito que morreu junto ao pai em Cerro Corá, ambos enterrados por suas próprias mãos (...) (DA SILVA, 2015, p.5).

Elisa Alicia Lynch faleceu em Paris em 25 de julho de 1886, um dia depois da data de aniversário de nascimento de Francisco Solano López. Embora na atualidade seja considerada heroína nacional, o depósito dos seus restos mortais no Oratório de la Virgen Nuestra Señora Santa María de la Asunción e Panteón Nacional de los Héroes ${ }^{22}$ - mausoléu das pessoas mais importantes da história paraguaia -, como era o plano original de Strossner, nunca foi efetivado. Houve forte oposição e influência da Igreja Católica que argumentou que Elisa foi uma mulher divorciada e que nunca se formalizou o casamento com o marechal. Por conta disso, argumentava a igreja, seus restos mortais não poderiam descansar dentro do oratório e mausoléu. Em 1970 seus restos mortais foram transferidos do cemitério "La Recoleta" para o Museo Histórico del Departamento de Defensa, em Assunção, onde permanecem até hoje. Permanecem também os pedidos para que sejam finalmente colocados ao lado do marechal no Panteón. Argumenta-se a seu favor que, além de heroína nacional e companheira do marechal, foi partícipe dos momentos mais emblemáticos dessa trágica guerra. Considerando sua importância, é constrangedor que nenhuma polca ou guarânia seja dedicada a ela.

Assim como no caso particular de Elisa Lynch, outras manifestações semelhantes de apagamento da mulher e discursos contraditórios são observadas nas ações nacionalistas empreendidas no Paraguai. A partir da Lei $N^{\circ} 498$ de 1974, decretada pelo go-

\footnotetext{
22 Inspirado nos monumentos franceses le Panthéon e Hôtel National des Invalides, o Panteón Nacional de los Héroes e também Oratório de la Virgen Nuestra Señora Santa Maria de la Asunción está localizado em Assunção, Paraguai. Sua construção iniciou em 1863 e era para ser originalmente um oratório, porém teve os trabalhos interrompidos durante a Guerra da Tríplice Aliança. Os trabalhos voltaram somente em 1929 sendo inaugurado em 1936, já como oratório e mausoléu. Nele descansam os restos das pessoas mais importantes da história do Paraguai como $1^{\circ}$ presidente constitucional Don Carlos Antônio López (1790 - 1862) e seu filho, o marechal Francisco Solano López; os restos de um soldado anônimo (homenagem aos soldados paraguaios); crianças mártires da batalha de Acosta Ñu; além de políticos e presidentes militares tais como 0 Dr. Eligio Ayala (1879 - 1930); o Dr. Eusebio Ayala (1875 - 1942); o General José E. Díaz (1833 - 1867); o Dr. Bernardino Caballero (1839 - 1912$) ;$ o tenente Adolfo Rojas Silva (1906 - 1927); o tenente e poeta Emiliano R. Fernandez (1894 - 1949); o marechal José Félix Estigarribia (1888 1940) e de sua esposa Julia Miranda Cueto (? - 1940), única mulher neste lugar.
} 
verno de Stroessner, cada 24 de fevereiro se comemora o dia da mulher paraguaia. Esse dia foi escolhido em homenagem a mulheres que, nessa data, em 1867, se reuniram em Assunção para a Primera Asamblea de Mujeres Americanas, e decidiram doar suas joias em auxílio as demandas da guerra contra a Tríplice Aliança. A pesquisadora Mary Monte de López (2020) indica que finalizada a guerra, Elisa Lynch voltou para Assunção feita prisioneira dos aliados. Como se não the bastassem a tristeza por ter visto morrer seu marido e filho - que ela enterrou com as próprias mãos - e ter sido feita prisioneira, ao chegar em Asunción muitas dessas mulheres da alta sociedade se reuniram para lhe reclamar a devolução das joias.

Ainda de acordo com a pesquisadora essa data não rende homenagem as verdadeiras mulheres que se entregaram pela causa do país.

(...) Sem desmerecer os propósitos das damas asuncenas, foram as mulheres do campo que verdadeiramente sustentaram a guerra. Isto é, graças a elas intermináveis caravanas de carroças descarregavam constantemente, nos lugares assinalados, os frutos das chácaras trabalhadas com esmero e admirável patriotismo (...) Quando acabou a guerra, que encheu de luto o país, nenhuma dessas mulheres se apresentou para reclamar que devolvessem sua doação ou que the pagassem pelo que fizeram. Tinham consciência de ter cumprido com seu dever para além do possível. Todavia, para o dia da mulher paraguaia é mais importante a doação de joias - logo reclamadas - do que o sacrifício desinteressado nas chácaras? Sacrifício que salvou da morte por fome muitos combatentes (de LÓPEZ apud DELVALLE, 2020, online - tradução nossa ${ }^{23}$ ).

No entanto, essas mulheres anônimas são consideradas e homenageadas no repertório musical popular. Em grande parte do repertório de músicas folclóricas do Paraguai a mulher paraguaia é representada como heroína e reconstrutora do país. Citadas como aquelas que lutaram lado a lado com os soldados. Símbolo de sacrifício e entrega pela pátria. Mulher abnegada. Mulher injustiçada. Mãe incansável, sempre a serviço da família. Imagens formadas talvez com boa intenção, mas que foram utilizadas para imprimir à marca d'água uma cultura machista e, por que não, militar. Entre elogios e discursos "rimbombantes" (retumbantes/ostentosos), parafraseando a pesquisadora Marakan (2013), se escondem o caráter perverso do discurso nacionalista e os modelos de feminidade assinados pelos homens, "categorias estereotipadas que contêm o abuso, a discriminação e a opressão da mulher" (MAKARAN, 2013, p.70 - tradução nossa24). Sobre essas contradições, Makaran afirma:

Paraguai é um dos países latino-americanos que mais atenção tem dedicado ao papel das mulheres na sua história, cujo discurso nacionalista se articulou em

\footnotetext{
23 No original: (...) Sin desmeritar los propósitos de las damas asuncenas, estaban las mujeres del campo que han sido las que verdaderamente sostuvieron la guerra. Es que, gracias a ellas, interminables caravanas de carretas descargaban constantemente, en los sitios asignados, los frutos de las capueras trabajadas con extraño y admirable patriotismo (...) Cuando se acabó la guerra, que llenó de luto el país, ni una de esas mujeres se presentó a pedir que le devolviesen el obsequio o le pagasen por ello. Tenía conciencia de haber cumplido con su deber más allá de lo posible. ¿Y para el día de la mujer paraguaya es más importante la donación de joyas - luego reclamadas - que el sacrificio desinteresado en las capueras? Sacrificio que salvó de morir de hambre a muchos combatientes (de LÓPEZ apud DELVALLE, 2020, online). Acesso em abril de 2020, no link: https://www.abc.com.py/edicion-impresa/opinion/2020/02/23/dia-de-la-mujer-paraguaya/
} 
torno das figuras femininas até o ponto de converter a atual [figura feminina] paraguaia em conduto simbólico da nacionalidade como tal (...). O reconhecimento simbólico não vai, no entanto, acompanhado do reconhecimento de fato, a sociedade paraguaia é profundamente machista e paternalista (MAKARAN, 2013, p.71 - tradução nossa ${ }^{25}$ ).

Infelizmente, é o que se observa em diversas canções, cujo repertório enfatiza o papel da mulher como objeto a serviço do homem, como um bem a ser conquistado cujos desejos e vontades não são levados em consideração. "Propiedad Privada ningo raka'e che la ahaihuva" (Propriedade privada era a quem eu amava), diz a canção. Se não há o homem, ela é tida como guerreira e autônoma. Mas ao seu lado, é mera coadjuvante. E ainda que o discurso poético musical aponte para a exaltação da mulher paraguaia, na prática não se verifica a efetividade de tal discurso.

\title{
4 - Mulher-flor e terra mãe, distribuições desequilibradas
}

\author{
Agora sei muito bem quanto \\ vale uma Propriedade Privada \\ quando eu menos esperava \\ fui abandonado \\ Fiquei só, queixando-me \\ como órfão \\ Por que isso aconteceu comigo? \\ estou triste e sem consolo
}

Sim, a imagem da mulher foi elevada à condição de heroína e de símbolo nacional, como se observa no resgate da figura histórica de Elisa Lynch e nas recorrentes referências às mulheres como seio do nacionalismo paraguaio. No entanto, a grande maioria das mulheres que auxiliaram nos momentos mais emblemáticos da história paraguaia, se encontram expropriadas de condições dignas de subsistência. É o que nos alerta Makaran (2013): "a maioria das mulheres que vivem em zonas rurais, inclusive as indígenas, vivem em condições de pobreza extrema por causa da concentração de terra e ampliação da agroindústria (MAKARAN, 2013, p.64 - tradução nossa ${ }^{26}$ ). Se analisamos essa situação em termos estatísticos, observamos que dos/as proprietários/as de terra paraguaia, apenas 9,4\% são mulheres (Makaran, 2013).

A distribuição de terras no Paraguai é problemática em relação às mulheres e aos pobres em geral. Outros dados estatísticos nos ajudam a entender a situação fundiária paraguaia. Ainda segundo Makaran (2013), cerca de 120 mil famílias, que representam 29,7\% da população rural do país, não possuem terra própria, e cerca de 300 mil famílias se consideram sem-terra ou com terra insuficiente. Isso dá ao Paraguai a liderança de

\footnotetext{
25 No original: Paraguay es uno de los países latinoamericanos que más atención ha prestado al papel de las mujeres en su historia, cuyo discurso nacionalista se ha articulado alrededor de las figuras femeninas hasta el punto de convertir a la actual paraguaya en conducto simbólico de la nacionalidad como tal. (...) El reconocimiento simbólico no va, sin embargo, acompañado del reconocimiento fáctico, la sociedad paraguaya es profundamente machista y paternalista (MAKARAN, 2013, p.71).

26 No original: Ia mayoría de las mujeres rurales, incluidas las indigenas, vive en condiciones de pobreza extrema a causa de la concentración de la tierra y la extensión de la agroindustria (MAKARAN, 2013, p.64)
} 
um ranking nada lisonjeiro. Segundo a pesquisadora Regina Kretschmer (2018), na atualidade o Paraguai conta com a distribuição de terras mais desigual do mundo: "2,6\% dos proprietários concentram $85,5 \%$ das terras, enquanto $91,4 \%$ da população camponesa dispõem apenas de 6\% da superfície agrícola" (KRETSCHMER, 2018, p.110).

Desde o fim da Guerra da Tríplice Aliança a disputa por terra é uma questão pungente no país. A grande revolução popular realizada durante o governo do Dr. Francia (1776 - 1840), que libertou os/as camponeses dos laços da dependência colonial e garantiu uma reforma agrária igualitária com $98 \%$ do território paraguaio a serviço do povo - como apontam pesquisadores como White (1989), Horst (2007), Kretschmer (2018) e Galeano (2018) -, foi completamente destruída depois da guerra e nunca mais foi refeita. "Em 1900, setenta e cinco indivíduos eram proprietários da metade do território, forçando os colonos camponeses e indígenas a saírem de suas propriedades. Foi então quanto a maior parte das terras indígenas no Chaco passaram a ser propriedade privada" (HORST, 2007, p.30 - tradução nossa27). Após constantes revoltas camponesas, em 17 de fevereiro de 1936 ocorre o golpe militar que ficou conhecido como Revolución Febrerista, cujo governo instituído assumiu a reforma agrária como uma de suas principais bandeiras. No entanto, esse governo teve pouco tempo e nenhuma condição de levar adiante seu intento:

Após 18 meses, o governo febrerista é derrotado e se inicia um período de contra reforma agrária que será aprofundado pela ditadura Stroessner (1954-1989), intensificando a lógica de concentração e de estrangeirização das terras, ao mesmo tempo em que, assessorado pela política da Aliança para o Progresso, obtinha cooptação e a legitimação do regime, mediante a adoção de um programa de colonização que visava assentar camponeses em regiōes de fronteira agrícola e promover a modernização capitalista na agricultura. Esta modernização se deu desde o Brasil em direção ao Paraguai, agricultores brasileiros com incentivo do governo paraguaio, instalaram seus cultivos, especialmente da soja, com base em uma matriz tecnológica baseada no monocultivo, com o uso intensivo de mecanização e de agrotóxicos (MATHEUS, 2016, p.3).

As reivindicações por justiça são evidentes nas polcas da época. É o que se observa em trechos de canções, tais como28: "Ei!.. Yvypóra cherekópe oîme che kéra yvoty /

27 No original: Para 1900, setenta y cinco individuos eran propietarios de la mitad del territorio, forzando a los colonos campesinos e indigenas a desalojar sus propiedades. Fue entonces cuando la mayor parte de las tierras indigenas en el Chaco pasaron a ser propiedad privada (HORST, 2007, p.30).

28 Um ponto importante a ser observado, comum às músicas que citamos, é o fato de que foram todas escritas e interpretadas por homens. Novamente encontramos uma lacuna, pois embora existam muitas mulheres autoras e intérpretes de música paraguaia - e exista também um forte movimento de feminino nas artes atualmente - é com muito esforço que elas conseguem ser reconhecidas como protagonistas artísticas. Um exemplo de iniciativa para reverter essa situação é a Fiesta Sonora, um festival musical realizado unicamente por mulheres e que teve a primeira e segunda edição em fevereiro e novembro de 2019. Segundo o depoimento de Rocío Robledo, uma das organizadoras, a percepção da falta de espaço em festivais musicais para projetos artísticos de mulheres e a reivindicação desses lugares resultou em algumas respostas bastante agressivas, inclusive dos próprios colegas músicos. "Me asusté de la violencia y virulencia con la que me contestó mucha gente. Por un lado, muchas chicas se identificaron y apoyaron lo que yo planteaba, pero, por otro, sentí muchísimo odio de mucha gente que me mandaba a la cocina" (ROBLEDO apud CARNERI, online, 2019). A histórica falta de consideração para com as mulheres protagonistas artísticas também pode ser observada na literatura dedicada à música paraguaia. Por exemplo, no livro Semblanzas Biograficas de Creadores e Intérpretes Populares Paraguayos (1992) do pesquisador Miguel Angel Rodriguez, se encontram 61 referências diretas a nomes masculinos no índice, contra apenas 5 referências a mulheres, sendo que numa delas em vez de citar o nome da artista lemos somente "Reminiscencias de dúos femininos y masculinos. Carta de Marino Barrientos". Outro exemplo é o Diccionario de la Música en el Paraguay (1999) do pesquisador Luis Szaran, onde se encontram 424 referências diretas a nomes masculinos contra 56 referências a artistas mulheres. Já no livro Ñande Purajhéi - Cancionero Popular Guaraní(2011), de Sergio Dacak e Rubén Riveros, encontramos 99 composições de homens contra apenas 6 composições de mulheres. 
Ei!.. Ha che páype ahavi'û añañuã ipoty kuru" (Ei!.. Sou o homem da terra que acaricia um sonho em flor / Ei!.. E acordado a projeto para vê-la desbotar),"Hi'ante tekove oisambyhýva ñane retã raperã vokoike hesaho ñanderehe chokokue tyre'yeta" (Gostaria que quem guie os destinos da pátria, um dia contemple as dificuldades que sofremos no campo em miserável orfandade), exclamam os primeiros versos da polca Chokokue Purahei (canto do camponês), de Francisco Alvarenga (1903 - 1957) e Mauricio Cardozo Ocampo (1907 - 1982), composta por volta de 1938.

Ou seja, a lembrança da revolução popular que outorgou ao povo paraguaio sua independência continua a ecoar nas polcas jahe'o. Porém, na prática, de forma similar a figura da mulher - heroína no imaginário e desprezada na realidade -, são negadas as condições concretas para que camponeses, camponesas e mulheres em geral conquistem condições mínimas de subsistência. Ha omanórõ ni yvyguýpe mboriahúgui nahendai (e ao morrer, nem debaixo da terra o pobre encontra um lugar para si) denuncia a polca Ha mboriahu composta em 1943 por Teodoro Salvador Mongelós ${ }^{29}$ (1914 - 1966), que morreu no exílio. Ou mesmo na nossa canção de referência: "Ko'anga aikuaáma mba'epa ivale Propiedad Privada / Aimo'avyetere pe ahaihueteva che aiguepe'a" (Agora sei muito bem quanto vale uma Propriedade Privada / quando eu menos esperava fui abandonado).

Mas, não faltam iniciativas dos/as camponeses, em especial das mulheres, com o objetivo de mudar essa situação. Observa-se o fortalecimento de organizações, articuladas em movimentos de resistência dentre as quais se destaca a Organización de Mujeres Campesinas e Indígenas Conamuri, criada em outubro de 1999. No entanto, em termos políticos, os governos pós-ditadura pouco avançaram no sentido de realizarem mudanças efetivas a favor dos/as menos favorecidos/as quanto a questão fundiária.

Diante do avanço dos grandes latifúndios o refrão "Mba'eikoajapota / mamoikoahata" (Que farei? / onde irei?), da polca de Cecilio Mareco Pereira continua latente. Longe de estar solucionada e pacificada, a luta pelo direito a terra segue pungente e cada vez mais acirrada.

\title{
5 - O compuesto de Lucía Agüero sobre o Massacre de Curuguaty
}

\author{
De agora em diante terei \\ muita atenção em meu caminho \\ para que nunca mais volte \\ a entrar em Propriedade Privada \\ Porque estou muito triste e \\ arrependido de minhas ações \\ Pois já não tenho \\ perdi aquela que amo
}

No dia 15 de junho de 2012, um contingente de mais de 300 policiais e membros do Grupo de Operaciones Especiales (GEO) se dirigiram a Curuguaty, Paraguai, a fim

\footnotetext{
29 Teodoro Salvador Mongelós (1914 - 1966) ficou conhecido como o Poeta dos humildes, sendo autor das letras de canções com forte conteúdo social. Em 1955 exerceu a presidência da Asociación Paraguaya de Artistas Nativos. Durante a ditadura de Alfredo Stroessner (1954 1989) foi exilado do país, vindo morar em São Paulo, Brasil. Seus restos mortais só puderam ser repatriados em 1994.
} 
de executar uma ordem de reintegração de posse a favor da firma Campos Morombi S.A.. O favorecido e suposto proprietário das terras era o empresário, ex-senador e ex-presidente do Partido Colorado, Blas N. Riquelme (1929 - 2012). A confusa operação resultou na morte de 17 pessoas (11 camponeses e 6 policiais) e ficou conhecida como Massacre de Curuguaty.

As famílias dos camponeses (em torno de 70 pessoas) que ocuparam essa porção de terras conhecidas como Marina $\mathrm{Kue}^{30}$ reclamavam que essas terras eram frutos das chamadas tierras malhabidas (terras ilícitas). É assim que se denominam as terras que foram confiscadas durante a ditadura de Stroessner supostamente a favor de camponeses para realizar a tão esperada reforma agrária, mas que acabaram sendo destinadas a parentes, amigos e correligionários do ditador, como Riquelme.

A briga era antiga. Em outras ocasiões, o Estado já havia se posicionado a favor do poderoso empresário em questões referentes a disputa de terras. Em 1985, por exemplo, Riquelme teria forçado a saída de comunidades indígenas Guarani Mbya de terras da sua fazenda La Golondrina, de "apenas" 75.000 hectares! O pesquisador Horst (2007) denuncia com detalhes a violência exercida:

(...) No dia seguinte, Riquelme em pessoa, acompanhado de 'testas de ferro' armados a cavalo, os rodearam para o despejo final. Primeiramente, vários peões golpearam aos homens mbya e violaram várias das mulheres. Com tratores demoliram as casas dos aldeões e prenderam-lhes fogo. Os indígenas fugiram apavorados para o bosque adjacente (HORST, 2007, p.260-261 - tradução nossa ${ }^{31}$ ).

O pesquisador Horst (2007) também denuncia outras ofensivas contra grupos mbya que ocuparam terras "pertencentes" a empresa Campos Morombí, de propriedade de Riquelme. O empresário nunca foi julgado por tais crimes. Ele faleceu em setembro de 2012 ostentando o título de um dos dez homens mais ricos do país. Alguns meses antes de sua morte, em junho, aconteceu aquele trágico incidente, no qual os camponeses que ocuparam uma parte de uma das suas fazendas na localidade de Curuguaty foram assassinados.

O massacre gerou também sérias consequências políticas. Uma semana depois, em 22 de junho de 2012, o presidente Fernando Lugo (1951 - ) foi destituído do cargo em um processo de impeachment que durou apenas cinco dias, somado a um julgamento de 24 horas, procedimento qualificado como irregular por organismos como UNASUR e MERCOSUR. Acabava ali a única vitória política de um partido diferente do Partido Colorado em muitos anos. O Partido Colorado, desde sua fundação ${ }^{32}$ (salvo os

\footnotetext{
30 Marina Kue é uma propriedade de um pouco mais de 1700 hectares na localidade de Curuguaty. 0 nome em guarani que significa Antiga Marinha, dado pelos camponeses do lugar, faz referência ao antigo Destacamento Naval Agropecuario da Armada Nacional. 0 informe de Direitos Humanos sobre o caso Marina Kue indica que "la ocupación por parte de dicho destacamento fue ininterrumpida desde finales de 1967 hasta finales de 1999" (VIDALLET, 2013, p.114).
}

31 No original: Al día siguiente, Riquelme en persona, acompañado de testaferros armados a caballo, los rodearon para el desahucio final. En primer lugar, varios peones golpearon a los hombres mbyá y violaron a varias de las mujeres. Con tractores demolieron las casas de los pobladores y les prendieron fuego. Los indigenas huyeron despavoridos hacia el bosque adyacente (HORST, 2007, p.260-261).

320 Partido Colorado foi fundado em 1887. Um dos seus fundadores foi o general Bernardino Caballero (1839 - 1912) que foi combatente na Guerra da Tríplice Aliança. Independente que quem é o próximo postulante ao posto mais alto do país, nas propagandas eleitorais sempre se apela ao passado glorioso e heroico que o partido "representa". 
períodos de 1904 a 1946, e 2008 a 2012) é o partido que governa o país. A retomada do poder pelo Partido Colorado após poucos meses de um governo interino também gerou desconfiança quanto ao teor político por trás da desastrosa operação de restituição de posse.

Além disso, tomando como base o testemunho de 84 policiais sobre a operação, em julho de 2016, o tribunal de Asunción condenou onze camponeses a penas entre 4 a 30 anos de prisão. Durante esse processo não se ouviu o testemunho de nenhum/a camponês nem se realizaram procedimentos de perícia criminalística no local do massacre. Tampouco se realizaram autopsias nos corpos dos policiais mortos para recolher as balas e comprovar de onde partiram os disparos. Suspeita-se que a polícia tenha atirado em camponeses e policiais, a fim de imputar aos camponeses uma violência que teria, por fim, justificado os assassinatos.

Em resposta, organismos internacionais como a Organização das Nações Unidas (ONU) e a Corte Interamericana de Direitos Humanos (CIDH) denunciaram o Estado Paraguaio por violações no processo de garantias judiciais e acesso à justiça. Em julho de 2018 as condenações contra os/as camponeses foram anuladas.

Entre as pesquisas que abordam esse trágico episódio no Paraguai, destacamos as registradas no livro La Masacre de Curuguaty (2013) de Julio Benegas Vidallet e no documentário Fuera de Campo (2014) dirigido por Hugo Giménez com produção de Tekoha Audiovisual para o IV DOCTV Latinoamérica. Neles encontramos o testemunho de Lucia Agüero, sobrevivente do massacre que, no momento dos disparos, correu a procura de abrigo para ela e para duas crianças. Nas palavras de Vidallet:

O que terá quebrado definitivamente nessa mulher? Que se terá quebrado definitivamente nessa criança de três anos que viveu as rajadas dos fuzis de metralhadora, estrondos de escopetas e rifles, o vôo baixo daquele helicóptero de observação, os estampidos das granadas jogadas desde o alto, a perseguição e as execuções (VIDALLET, 2013, p.80 - tradução nossa ${ }^{33}$ ).

Por meio de um compuesto, antiga forma musical paraguaia que relata fatos verídicos, Lúcia Agüero descreve aquele dia e denuncia o modo como foram tratados os camponeses mortos e o processo jurídico que lhes foi imposto. Compuesto é um gênero musical paraguaio que se caracteriza pela crônica narrativa que relata fatos que causaram comoção na sociedade paraguaia. Os compuestos mais antigos que se tem referência datam da primeira década do século XX e são considerados um importante meio de transmissão de acontecimentos marcantes na sociedade. Eles são cantados nos diversos ritmos paraguaios com polca, guarânia e rasguido doble.

Tanto a polca jahe'o como o compuesto são formas musicais de registro de narrativas populares, a diferença está na poética do primeiro e no realismo do segundo. Ou seja, o compuesto se aproxima mais de uma crônica narrativa, preocupando-se em descrever dia, local, nome de pessoas, com vistas a perenizar informações sobre o relato. 
O compuesto cantado a cappella por Lucia Agüero, que relata o acontecido em Curuguaty, é apresentado no documentário Fuera de Campo (2014), no minuto 44, e se encontra disponível na internet com acesso livre na plataforma vimeo no seguinte link: https://vimeo.com/125523406

A seguir transcrevemos seu relato, em jopara.

Versão original

Verso 1

Upépe ningo oikóma hete vece desalojo, policía mbaretépe umi carpero pe omoiama Upégui oñeformá entre setenta unido iderecho odefendemivo hasta omanovareaha

\section{Verso 2}

El vierne el 15 de junio, en el año 2012, osêjeima la orden desalojo oikohaguâ Carperokuéra ojeprepara ha oavisa policiápe: romanombáta ko'ape historia opytă haguã

\section{Verso 3}

A la siete de la mañana policía ja oallanáma Comisário Lovera oarteáma mâapa jefe oporandu Che ha'e he'i Pindu osêvo oimongetávo Avelino Espinola he'ipávo hesêma oñembokapu

\section{Verso 4}

Pastotýre isarambi odispara la pyaevéva ha umi itapykuéva yvatégui ojejapi Helikóterope oî policía con metralleta ha umi odisparaséva cobardemente ojejapi

\section{Verso 5}

Ambulancia ogueroja policía muerto ha erido campesino katu erido pastotýre ojeehekuta Ule húme ojelelia oñemombo ojoári hopital Paraguaýpe pasillope inemba

\section{Verso 6}

Culpable ojehecha ha'eha parlamentário, senador há dipudado estáncia járape oladea Policia ojeignora há ojefelicita opytávo campesino sobreviviente imputado opytapa

\section{Português (tradução nossa)}

\section{Verso 1}

Lá houveram vários atos de despejo

os policiais com sua força os camponeses expulsaram

Depois disso se uniram entre setenta pessoas

para defender seus direitos até a morte

\section{Verso 2}

Na sexta-feira, 15 de junho, no ano 2012 ,

Se emitiu uma nova ordem de despejo

Os camponeses se prepararam e deram aviso a policia:

Aqui vamos morrer todos para que fique na história

\section{Verso 3}

As sete da manhã a polícia irrompeu no lugar, o comissário Lovera perguntou quem era o chefe sou eu, respondeu Pindú, indo para conversar,

apenas falou seu nome - Avelino Espinola - e começaram a atirar nele

\section{Verso 4}

Na pastagem se dispersaram, correndo os mais ágeis, já os atrasados, desde o alto atiravam neles No helicóptero estavam policiais com metralhadores os que tentaram correr, covardemente foram fuzilados

Verso 5

A ambulância fazia o traslado de policiais mortos e feridos, já os camponeses feridos foram executados na pastagem Em sacos pretos foram colocados e amontoados um em cima do outro nos corredores do hospital de Assuncão, os corpos já tinham cheiro

\section{Verso 6}

Viu-se que os culpados foram os parlamentares, os senadores e deputados saíram em favor do dono da fazenda A polícia saiu impune e foi felicitada, os camponeses sobreviventes foram todos indiciados

\section{Verso 7}

Até aqui vou contar... (corte súbito)

Apevéntema amombe'u... (corte súbito)

O relato descreve a violência com que os camponeses foram tratados, sem qualquer chance de defesa. E ressalta a forma como o Estado paraguaio tem tratado a questão fundiária sob a perspectiva camponesa.

Lucia diz que "até aqui vou contar", e interrompe de súbito a música. O choro a faz interromper. Choro de revolta e de tristeza impresso naquilo que foi composto e também naquilo que sai espontaneamente na interpretação. E assim encontramos a música como 
meio fundamental de registro de narrativas e de transmissão de histórias que seguem reivindicando melhores condições de vida das paraguaias e paraguaios camponeses.

Os versos de Propiedad Privada retornam aqui, em diálogo com esse estado de coisas. "Porque ambyasy añarrepenti cherembiapokuere / Na cheko'aveima já / aperdeteva ahaihuvache" (Porque estou muito triste e arrependido de minhas ações / Pois já não tenho / perdi aquela que amo). Aquela que eu amo pode ser tanto a desejada terra, fundamento para se obter as condições mínimas de subsistência, como pode se referir a tantos e tantas camponeses e indígenas, assassinados/as em ações de reintegração de posse que mais se parecem a atividades de execução sumária dos pobres que ousam se contrapor aos ricos e poderosos. O arrependimento citado pode ter relação direta com o custo pago em vidas pelas tentativas de obter alguma justiça social.

\section{5 - Considerações finais}

A polca Propiedad Privada, de Cecilio Mareco Pereira - exemplar do gênero purahei jahe'o e cuja gravação com sonoridade "eletrônica" realizada pelo grupo Odilio Román y Los Románticos fez grande sucesso no Paraguai nos anos 2000 , traz latente a situação social do interior do Paraguai - situação que se estende desde o fim da Guerra da Tríplice Aliança, em 1870, até os dias atuais. Dois aspectos complementares se fazem presentes na letra da música: a situação da mulher como objeto de desejo e de posse do homem, e as disputas fundiárias no país.

Do ponto de vista da mulher, o que se observa é uma imbricada relação entre a mulher e o nacionalismo na cultura paraguaia. No entanto, apesar da elevação da mulher como símbolo do protagonismo na luta e resistência paraguaia, o que temos na prática cotidiana é a configuração de uma mulher inferiorizada e expropriada das condições de subsistência. Isso é um aspecto contraditório a respeito do tratamento dado à mulher de forma especial, considerando sua importância na narrativa nacional.

Do ponto de vista das disputas por terra, a questão da pobreza e da violência social também ganham destaque. Se o Paraguai do século XIX vivenciou, sob a gestão de Dr. Francia, uma tentativa de distribuição um pouco mais justa da terra e dos recursos esse sonho foi completamente dizimado com a Guerra da Tríplice Fronteira e permanece como utopia não realizada na história subsequente. A terra paraguaia não pertence ao camponês que nela trabalha. E aqueles que lutam por condições mais igualitárias de sobrevivência tem pagado, muitas vezes com a própria vida, por sua ousadia em se opor aos grandes latifundiários. A música popular paraguaia segue ocupando uma função social de registro e transmissão de histórias, sonhos e desejos dos/as camponeses.

Desde aqueles mais pretensamente singelos, como os relativos à desenganos amorosos, como aqueles mais engajados, relativos à pobreza e expropriação - tais narrativas, seguem resistindo no cancioneiro paraguaio, resistem no imaginário desse povo. $E$, ao existir, resistem como desejo e luta por uma vida digna. 


\section{Referências}

ANTAR, M.; OLIVEIRA, Y. Apontamentos sobre narrativa oral, identidade, machismos e feminismos no compuesto Mateo Gamarra. In: SUZUKI, J.; ARAUJO, V. Identidade e diferença na canção latino-americana. FFLCH/USP. São Paulo, 2019.

ASUNCIÓN. Ley № 4366 / Declara día de la polka paraguaya el 15 de setiembre de cada año. Disponível em: <http://www.bacn.gov.py/leyes-paraguayas/3723/ley-n4366-declara-dia-de-la-polka-paraguaya-el-15-de-setiembre-de-cada-ano>

CARNERI, Santiago. El grito musical de las mujeres paraguayas: Asunción celebra la Fiesta Sorora, un festival dirigido, producido y protagonizado por mujeres. El País, Asunción, 2 de dezembro de 2019. Disponível em: <https://elpais.com/ cultura/2019/12/02/actualidad/1575306734_245346.html>

CHAMORRO, Eduardo. Nacionalismo cultural paraguayo en la obra de Emiliano R. Fernández en el contexto de la Guerra del Chaco entre Bolivia y Paraguay (1932/1935). Revista Internacional de Investigación en Ciencias Sociales, v.9 n.1, ISSN 2226-4000, Asunción, Paraguay, 2013.

CREYDT, Oscar. Formación Histórica de la Nación Paraguaya. Editorial y Librería ServiLivro, Asunción, Paraguay, 2010.

CUEVAS, Belén. La kuña guapa guaraní, una valiente guerrera aún no valorada como debiera. ABC Color. Asunción, 22 de fevereiro de 2020. Disponível em: https://www. abc.com.py/periodismo-joven/2020/02/22/la-kuna-guapa-guarani-una-valienteguerrera-aun-no-valorada-como-debiera/

DA SILVA, Natalia. Em defesa de Elisa Lynch: Autobiografia e biografias no embate de memórias sobre a Guerra do Paraguai. XXVIII Simpósio Nacional de História - Lugares dos historiadores: velhos e novos desafios. Florianópolis, Santa Catarina, 2015.

DACAK, Sergio; RIVEROS, Rubén. Ñande Purajhéi - Cancionero Popular Guaraní. Ediciones Arasunú. Asunción, Paraguay, 2011.

DELVALLE, Alcibiades. Día de la Mujer Paraguaya. ABC Color, Asunción, 23 de fevereiro de 2020. Disponivel em: < https://www.abc.com.py/edicion-impresa/ opinion/2020/02/23/dia-de-la-mujer-paraguaya/>

GALEANO, Eduardo. Las venas abiertas de América Latina. Siglo Veintiuno Editores, Buenos Aires, Argentina, 2018. 
GIMÉNEZ, Hugo. Fuera de Campo. Documental para el IV DOCTV Latinoamérica. Direção Hugo Giménez. Produção Tekoha Audiovisual. 2014. Link: https://vimeo. com/125523406

HIGA, Evandro. Polca Paraguaia, Guarânia e Chamamé: estudos sobre três gêneros musicais em Campo Grande-MS. Editora UFMS, 2010.

Para fazer chorar as pedras: o gênero musical guarânia no Brasil, décadas 1940/50. Tese (Doutorado em Música), Universidade Estadual Paulista UNESP, Instituto de Artes, São Paulo, 2013.

HORST, René. El régimen de Stroessner y la Resistencia Indígena. CEADUC - Centro de Estudios Antropológicos de la Universidad Católica "Nuestra Señora de la Asunción". Imprenta Salesiana, Asunción, Paraguay, 2007.

IKEDA, Alberto. Culturas populares no presente: fomento, salvaguarda e devoração. Revista Estudos Avançados, v.27 n.79, São Paulo, 2013.

KERMAN, Joseph. Musicologia. São Paulo, Martins Fontes, 1987.

KRETSCHMER, Regina. Conflictos agrarios y luchas campesinas en el Paraguay. In: FERNANDES; RINCÓN; KRETSCHMER (org.). La actualidad de la reforma agraria en América Latina y el Caribe. ISBN 978-987-722-371-2, 2018.

LAMBERT, Peter. El discurso nacionalista en el Paraguay: Desde lo disidente a lo hegemónico. In: CASAL, Juan Manuel; WHIGAM, Thomas L. (Orgs.). Paraguay: Investigaciones de historia social y política. III Jornadas Internacionales de Historia del Paraguay en la Universidad de Montevideo, 2013.

MAKARAN, Gaya. La imagen de la mujer en el discurso nacionalista paraguayo. Latinoamérica, Revista de estudios Latinoamericanos, n.57, pp.43-75, ISSN 2448-6914, México, 2013.

MATHEUS, Fernanda. A questão agrária e a luta pela reforma agrária no Paraguai. Revista Boletim Dataluta, n.102 jun., ISSN 2177-4463, 2016.

MIDDLETON, Richard. Studying Popular Music. Philadelphia, Open University Press, 1990.

ORTIZ, Gonzalo. Considerações sobre a música pós-tonal para piano de compositores paraguaios. Dissertação (mestrado), Instituto de Artes, Universidade Estadual de Campinas, 2018 
PEREIRA, Arturo. Origen Social de la Música Popular Paraguaya. Fondec. Imprenta Arte Nuevo, Asunción, Paraguay, 2011.

RODRIGUEZ, Miguel. Semblanzas Biográficas de Creadores e Intérpretes Populares Paraguayos. Ediciones Compugraph. Asunción, Paraguay, 1992.

Sem autor. DÍA DE LA POLCA PARAGUAYA: El género musical que resiste el paso del tiempo. Ultima Hora, Asunción, 15 de setembro de 2018. Seção Nacionales. Disponível em: <https://www.ultimahora.com/dia-la-polca-paraguaya-el-genero-musical-queresiste-el-paso-del-tiempo-n2707491.html>.

ABUELO MÚSICO SUEÑA CONOCER A ODILIO ROMÁN. Extra, Asunción, 14 de setembro de 2016. Seção Actualidad. Disponível em: <https://www.extra.com.py/ actualidad/abuelo-musico-suena-conocer-odilio-roman-n1538846.html>.

CECILIO MARECO PEREIRA. Disponível em: http://www.portalguarani. com/2871_cecilio_marecos_pereira.html

SE APAGÓ LA VOZ DEL FOLCLORISTA ODILIO ROMÁN, en Posadas. Ultima Hora, Asunción, 05 de agosto de 2019. Seção Arte y Espectáculos. Disponível em: <https://www.ultimahora.com/se-apago-la-voz-del-folclorista-odilio-romanposadas-n2836087.html>.

. LAS 6 CANCIONES DE ODILIO ROMÁN QUE QUEDARÁN EN LA MEMORIA. TVO - Revista paraguaya de actualidad y farándula, Asunción, 05 de agosto de 2019. Disponivel em: <https://tvo.ultimahora.com/las-6-canciones-odilio-roman-quequedaran-la-memoria-n2836128.html>.

ODILIO ROMÁN ESTÁ POLQUEANDO EN EL CIELO. Extra, Asunción, 05 de agosto de 2019. Seção Fama. Disponível em: <https://www.extra.com.py/fama/odilioroman-esta-polqueando-el-cielo-n2836140.html>.

POLKAPÚPE DESPIDIERON A ODILIO ROMÁN. Extra, Asunción, 06 de agosto de 2019. Seção Fama. Disponível em: < https://www.extra.com.py/fama/polkapupedespidieron-odilio-roman-n2836354.html>.

GRUPO LOS ROMÁNTICOS LLEVA LA POLCA A EUROPA. Ultima Hora, Asunción, 15 de junho de 2011. Seção Arte y Espectáculos. Disponível em: < https:// www.ultimahora.com/grupo-los-romanticos-lleva-la-polca-europa-n437631.html>.

SILVEIRA, Mauro. A batalha de papel: a charge como arma de guerra contra o Paraguai. Editora da UFSC, Florianópolis, 2015. 
TORRES, Rodrigo. Creación Musical e Identidad Cultural en América Latina: Foro de Compositores del Cono Sur. In: Revista Musical Chilena, año XLII, enero-junio, Nº169, p.58-85, 1988.

VIDALLET, Julio B. La Masacre de Curuguaty. Arandurã Editorial, Asunción Paraguay, 2013.

WHITE, Richard. La Primera Revolución Popular en América - Paraguay (1810-1840). Industrial Grafica Comuneros S.A., Asunción, Paraguay, 1989.

ZSARÁN, Luis. Diccionario de la Música en el Paraguay. Editora Zsarán, Asunción Paraguay, 1999. 